Paár Dávid, Ambrus Rita Anna, Szóka Károly

\title{
Gazdasági elemzés a beszámolók információi alapján
}

Szerkesztette: Paár Dávid, Szóka Károly 



\section{Paár Dávid}

Ambrus Rita Anna

Szóka Károly

\section{GAZDASÁGI ELEMZÉS}

\section{A BESZÁMOLÓK INFORMÁCIÓI ALAPJÁN}

Szerkesztette: Paár Dávid, Szóka Károly

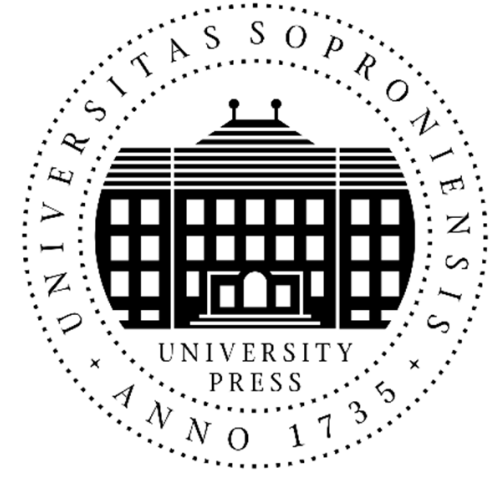

SOPRONI EGYETEM KIADÓ

SOPRON, 2021 
Dr. Paár Dávid

Dr. Ambrus Rita Anna

Dr. Szóka Károly

Felelős kiadó: Prof. Dr. Fábián Attila

a Soproni Egyetem rektora

Szerkesztette: Dr. Paár Dávid, Dr. Szóka Károly

Lektor: Dr. Pataki László

ISBN 978-963-334-401-9 (nyomtatott)

ISBN 978-963-334-402-6 (online)

DOI 10.35511/978-963-334-402-6

Jelen tananyag az „EFOP-3.5.1-16-2017-00012 - Felsőfokú duális képzések fejlesztése a Nyugat-magyarországi peremvidéken” című projekt támogatásával valósult meg.

Az azonos című e-learning tananyag javított, bővített kiadása.

(C) Dr. Paár Dávid, Dr. Ambrus Rita Anna, Dr. Szóka Károly, 2021

Minden jog fenntartva, beleértve a sokszorosítás, másolás és másodközlés jogát is! Nyomda: Lővér Print Kft., Sopron, 2021. 


\section{Tartalomjegyzék}

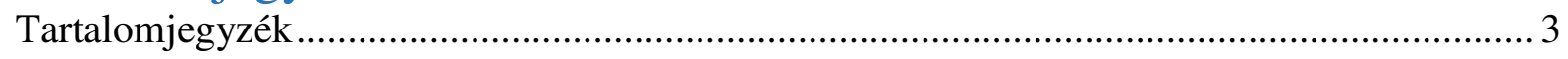

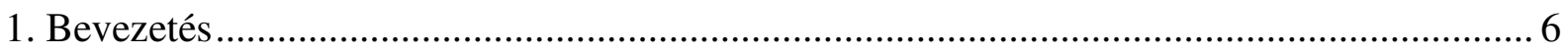

2. Elemzés szükségessége, célja, feladata (Dr. Paár Dávid) …............................................ 8

2.1. Az elemzés fogalma, a gazdasági elemzés tárgya ................................................... 8

2.2. A gazdasági elemzés célja, szükségessége, döntéshozatali szerepe, feladatai és

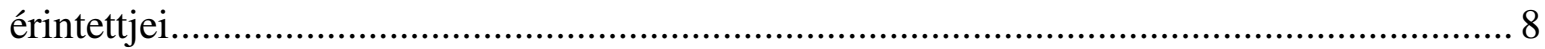

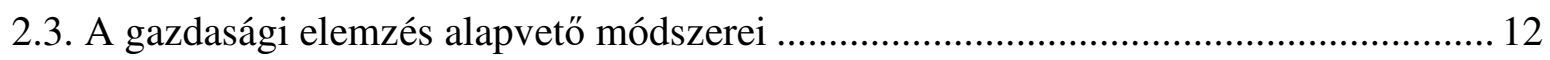

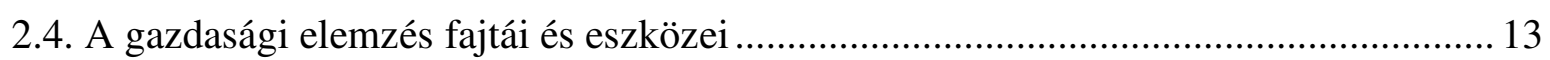

3. Számviteli beszámolók szerepe és jelentősége (Dr. Szóka Károly).................................... 22

3.1. A számviteli politikával szemben támasztott követelmények..................................... 23

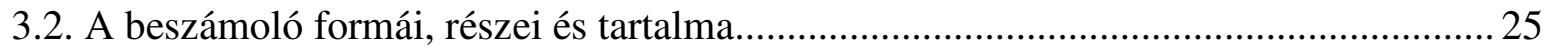

3.3. A beszámoló letétbe helyezése és közzététele .......................................................... 27

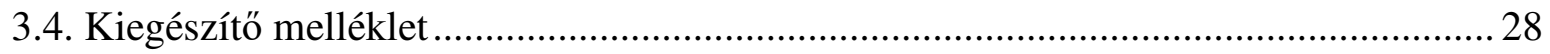

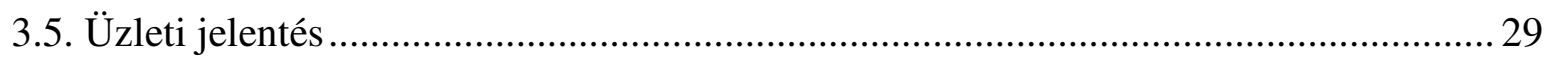

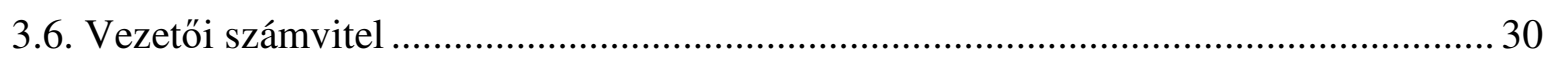

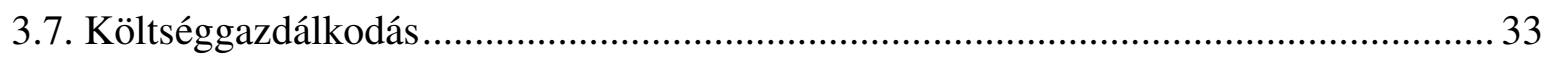

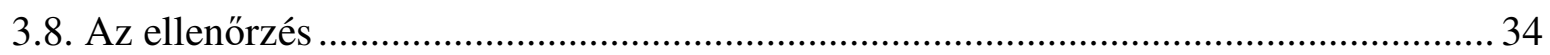

4. A vagyoni helyzet elemzése (Dr. Paár Dávid) ................................................................... 39

4.1. Az eszközök és források belső arányainak vizsgálata.................................................. 39

4.1.1. A leggyakrabban használt, eszközszerkezetet jellemző módszerek, mutatók......... 40

4.1.1.1. A befektetett eszközök fö́csoportját elemzö mutatók ........................................ 42

4.1.1.2. A forgóeszközök föcsoportját elemzö mutatók ............................................... 44

4.1.2. A leggyakrabban használt forrásszerkezetet jellemző módszerek, mutatók ........... 47

4.1.2.1. A saját töke fö́csoportját elemzö mutatók ..................................................... 50

4.1.2.2. A céltartalékok fócsoportját elemzö mutatók .............................................. 52

4.1.2.3. A kötelezettségek fö́csoportját elemzö mutatók …….........................................52

4.2. Az eszközök és források egymással történő összehasonlítása ..................................... 55

4.3. Working capital - müködő tőke - forgótőke - nettó forgótőke ...................................... 56

5. A pénzügyi helyzet elemzése rövid és hosszú távon (Dr. Paár Dávid) ................................. 58

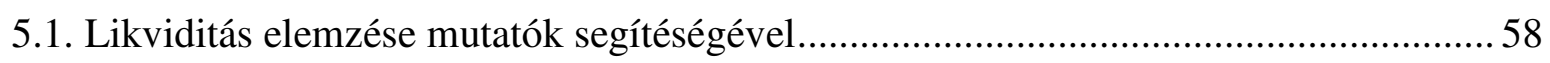

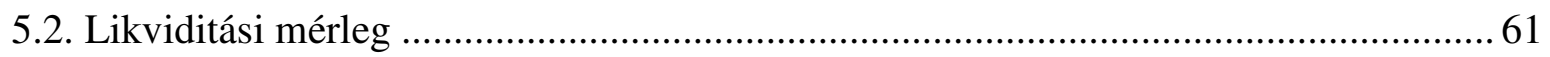

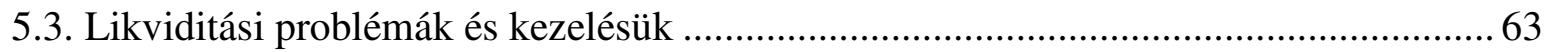

5.4. Adósság-állomány elemzése mutatók segítéségével ................................................. 64

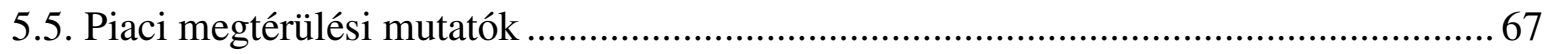

6. Jövedelmezőség elemzése (Dr. Szóka Károly) …............................................................. 70

6.1. A vállalkozás eredményének képződése és annak szintjei........................................ 70 


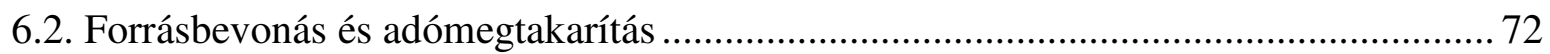

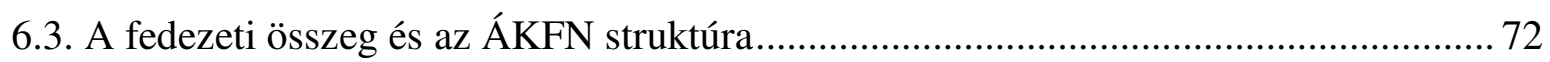

6.4. Az eredményesség vizsgálata és a jövedelmezőségi mutatók ....................................... 74

6.4.1. Átlagos fedezeti hányad (Bruttó jövedelmezőség, Return on Sales (ROS)) ........... 76

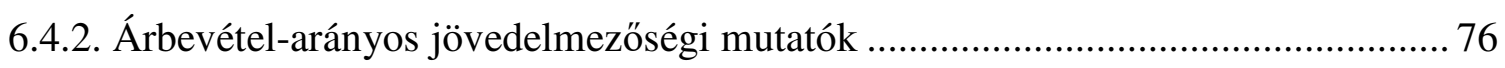

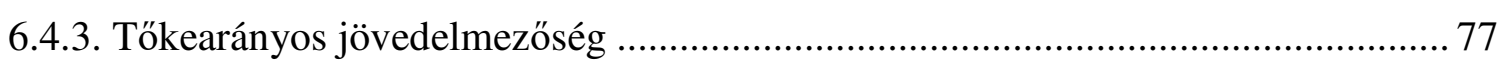

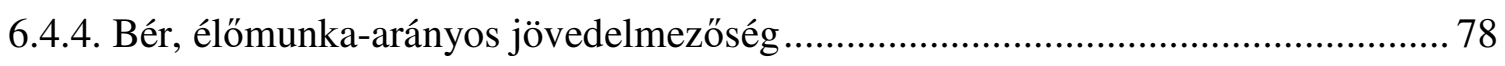

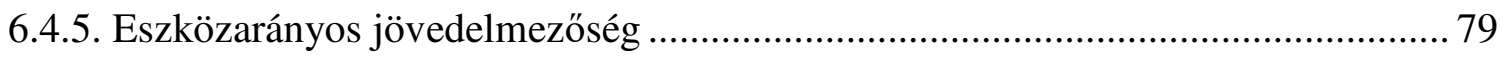

6.4.6. Erőforrás-arányos (komplex) jövedelmezőség..................................................... 80

6.4.7. Tőzsdei társaságok jövedelmezőségének elemzése ............................................. 81

6.5. A mutatók rendszerbe foglalása - a Du Pont rendszer ................................................ 82

6.6. Kereskedelmi vállalkozások eredményelemzése .................................................... 84

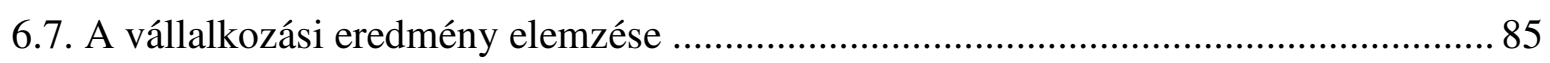

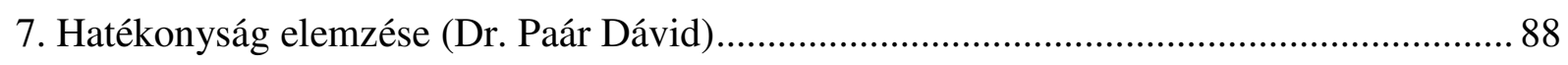

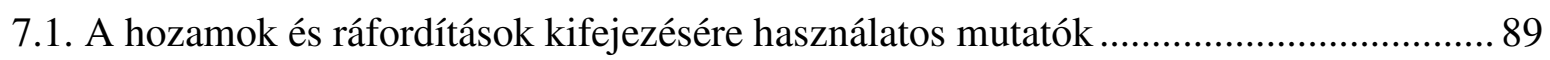

7.2. Ágazattól függetlenül használható hatékonysági mutatók ....................................... 91

7.3. Termelő vállalatok hatékonyságát értékelő mutatók............................................... 94

7.3.1. Komplex hatékonysági mutató ......................................................................... 94

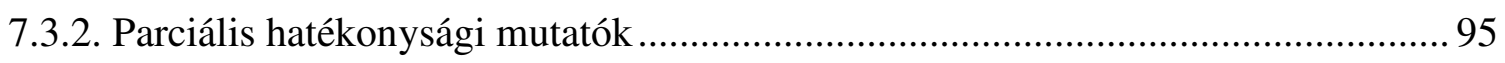

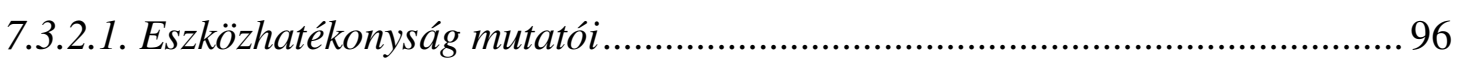

7.3.2.2. Termelési költségek hatékonysági mutatói ................................................... 97

7.3.2.3. Töke- és eredményhatékonysági mutatók ...................................................... 98

7.4. Kereskedelmi vállalatok hatékonyságát értékelő mutatók ........................................ 99

7.4.1. Élőmunka-hatékonyság mutatói a kereskedelemben .......................................... 99

7.4.2. Eszközhatékonyság mutatói a kereskedelemben................................................ 101

7.5. Mezőgazdasági vállalatok hatékonyságát értékelő mutatók ..................................... 101

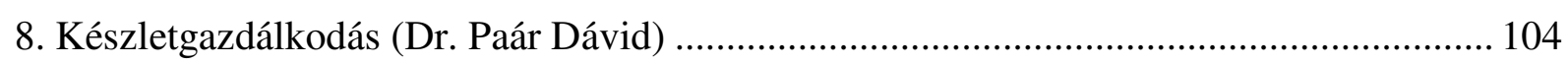

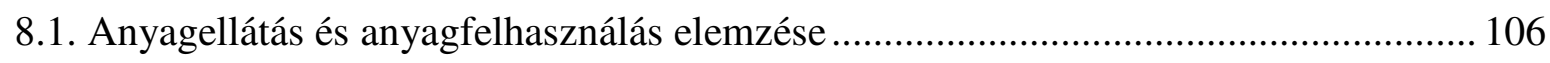

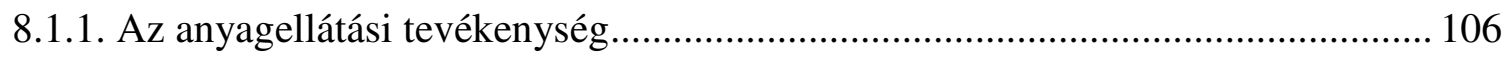

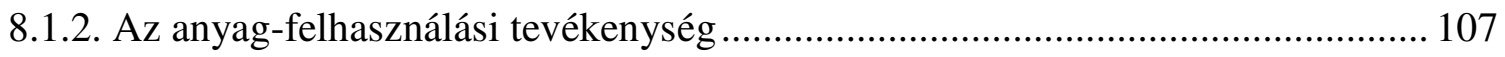

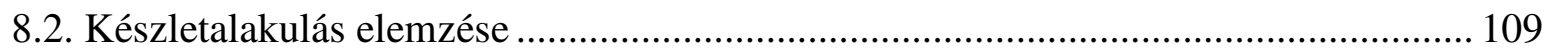

8.2.1. Készletnormáktól való eltérések elemzése....................................................... 109

8.2.2. Készletösszetétel, készlethatékonyság dinamikus elemzése ............................... 110

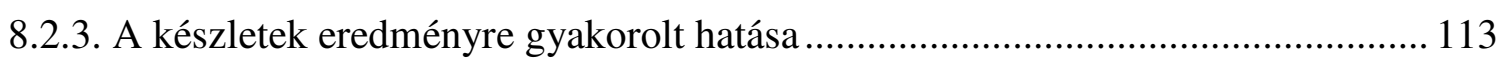

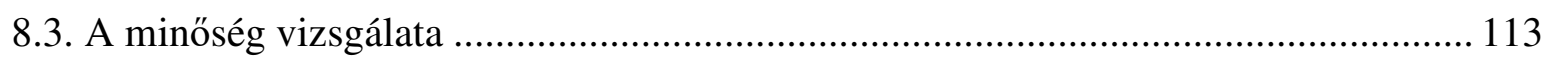

8.3.1. A minőség vizsgálata a vevőelégedettség szempontjából................................. 113 
8.3.2. A minőség vizsgálata a gyártási folyamat és a késztermékek minőségének szempontjából

8.3.3. A minőség vizsgálata a minőséggel kapcsolatos költségek szempontjából .......... 116

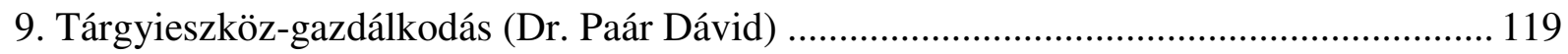

9.1. Tárgyi eszközök összetételének és használhatóságának vizsgálata ........................... 121

9.2. Tárgyi eszközök kapacitáskihasználtsága és kapcsolódó költségei ............................ 124

9.2.1. A müszaki kapacitáskihasználtság értékelése ................................................... 125

9.2.2. A kapacitáskihasználáshoz kapcsolódó költségek és a gazdasági

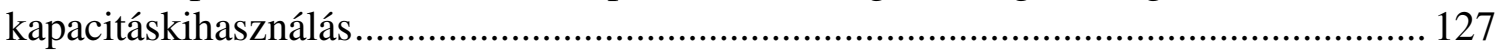

10. Létszám- és bérgazdálkodás (Dr. Ambrus Rita Anna) .................................................. 130

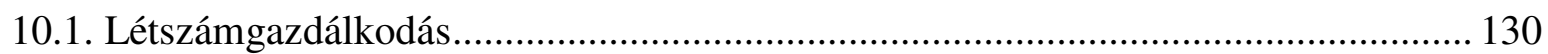

10.2. Munkaidőkihasználás és az élőmunka teljesítményének elemzése.......................... 132

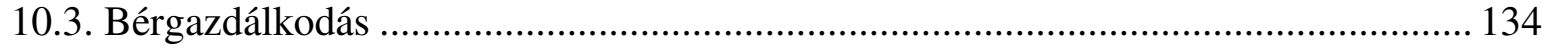

10.4. A bérgazdálkodás elemzéséhez használt föbb mutatók ......................................... 136

11. Kereskedelem és vendéglátás jellegzetességei (Dr. Paár Dávid) .................................... 139

11.1. Az áruforgalom és készletgazdálkodás sajátosságai a kereskedelemben.................. 139

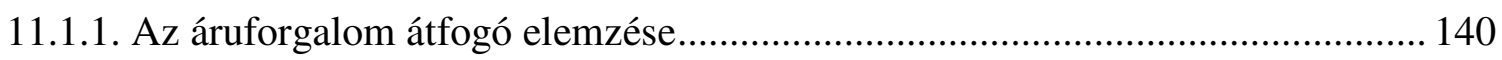

11.1.2. A beszerzés (áruellátás) elemzése ...................................................................... 142

11.1.3. A készletezési tevékenység (árukészlet-állomány) elemzése ........................... 144

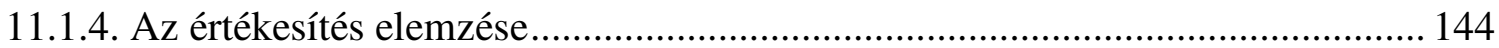

11.2. A tárgyi eszköz-gazdálkodás sajátosságai a kereskedelemben ............................... 147

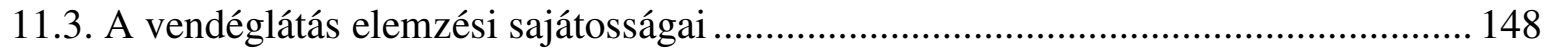




\section{Bevezetés}

A vállalatok müködésének tanulmányozása, a gazdasági jelenségek és események megfigyelése elengedhetetlen napjainkban. Ezek gazdasági-pénzügyi elemzését nyugodtan nevezhetjük olyan alapfeltételnek, amelyet minden cégnek el kell végeznie, végre kell hajtania. A mindennapok során megmutatkozó gazdasági összefüggések, az azokra ható tényezők ismerete fontos és szükséges, melyek megismerésében segítenek az elemzési módszerek és eszközök.

A cégek, a tulajdonosok és a menedzsment nap, mint nap rengeteg adattal és információval találkoznak, melyeket át kellene gondolniuk, melyeket elemezni szükséges. Ezek az adatok keletkezhetnek a cégen belül, de érkezhetnek a külvilágból is, akár egy versenytárs, akár egy beszállító is szolgálhat releváns információkkal.

Ez a tevékenység mára már szakértői feladattá vált, ehhez speciális szakértelem szükséges. A munka elvégzése során rengeteg releváns információhoz juthatnak az érintettek (stakeholderek), ám ezek értelmezése sokszor korlátokba ütközik, hiszen nem mindenki pénzügyi szakember, azaz az elemzési munkának ez az értelmezés és interpretálás is része lett.

Ez a gazdasági elemzési tevékenység irányulhat a múltra, amikor tény adatokat használunk fel, de irányulhat a jelenre is, amikor például a terv-tény adatokat hasonlítjuk össze és okokat keresünk (ok- okozati összefüggéseket) az eltérésekre, hiszen magyarázatokra van szükségünk. Ez a munka sohasem az asztalfióknak készül, a megkapott információk alapján visszaigazolásokat láthatunk, beavatkozásokra lehet szükség, azaz befolyásolja a jelent és egyben a jövőt is.

Olyan szakmai módszertant használunk fel, mely nem csak a mutatók felépítésére, tartalmának bemutatására szorítkozik, hanem kiemeli a közöttuik lévő összefüggéseket is.

Anyagunk természetesen a fogalmi meghatározásokkal indul, hiszen tisztáznunk kell, mit jelent a gazdasági elemzés és milyen módszerekkel láthatunk neki a munkának. Kitérünk a legfontosabb statisztikai és számviteli alapokra, témakörökre is, hiszen ezekre mind-mind támaszkodunk - sőt támaszkodnunk kell - elemzéseink során. Ezt követi a módszerek bemutatása és az elemzések végrehajtásának menete, logikai felépítése. Természetesen a fejezetek között lesznek átfedések is, lesznek olyan témák, fogalmak, melyek többször fel-felbukkannak, ez is azt bizonyítja, hogy a gazdasági életben, minden, mindennel összefügg.

A teljesség igénye nélkül, a jegyzet során érinteni fogjuk a vagyoni és pénzügyi helyzet, a jövedelmezőség és hatékonyság témaköreit. Ezt követi az eredmény részletes elemzése, a készlet, a tárgyi eszköz, illetve a létszám- és bérgazdálkodás.

A fejezeteket megtanuló, majd alkalmazó tisztelt Olvasó olyan nélkülözhetetlen ismeretekre és képességekre tesz szert, mint például a számviteli és pénzügyi ismeretek felhasználása, az elemzési módszerek, az analitikus látásmód és a pénzügyi-gazdálkodási helyzet felmérése és elsajátítása. Nem titkolt célunk, hogy a szakkönyv az elméleti és gyakorlati ismereteket össze- 
kapcsolja, hogy a gazdálkodás elemzése során a Hallgatót komplex gazdasági helyzet értékeléséhez segítse, valamint értelmezni tudja az eredménytermelő képességet, annak tervezését és utólagos elemzését.

Egy ilyen komplex anyag olvasásakor, illetve a tanórákon, majd az otthoni tanulás során nagyon fontos az, hogy hogyan is tanulunk, hogy hogyan készülünk fel, azaz hogyan sajátítjuk el az anyagot. Természetesen az első lépés az, hogy el kell olvasni az anyagot, meg kell hallgatni az Oktatót. Ezek után javasoljuk a kisebb feladatokkal begyakorolni az adott témakört, elemezve az adott mutatókat, nem elfelejtve, hogy az elemzés nem azok kiszámolását jelenti, hanem azok értelmezését, azaz valódi elemzését. Ehhez hozzátartozik a változások figyelembe vétele, az ok-okozati összefüggések bemutatása, a döntések következményeinek bemutatása, a miértekre való válaszolás. A kisebb részek után viszont - ahogy a valós életben is - mindig komplexen kell gondolkodunk, a vállalatot, mint egészet minden irányból elemeznünk kell, minden területet át kell tekintenünk, figyelembe véve a tulajdonosi elvárásokat, a menedzsment tevékenységét és céljait.

A Szerzők kellemes és hasznos olvasást, időtöltést kívánnak.

Sopron, 2021. augusztus 10.

Dr. Ambrus Rita Anna, Dr. Paár Dávid, Dr. Szóka Károly

A Gazdasági elemzés a beszámolók információi alapján címü elektronikus jegyzet az EFOP 3.5.1 pályázat keretében készült a Soproni Egyetem Lámfalussy Sándor Közgazdaságtudományi Karán. 


\section{Elemzés szükségessége, célja, feladata}

\subsection{Az elemzés fogalma, a gazdasági elemzés tárgya}

Az „elemez” szó, mely az „elem” szó származékának tekinthető, a nyelvújítás korában jött létre az 1800-as évek közepe tájékán. A magyar nyelv értelmező szótára szerint az „elemzés” szó „,az elemez igével kifejezett tevékenység, eljárás; az a cselekvés, hogy valamit elemeznek; valaminek részletes vizsgálata, részekre bontása, taglalása, boncolása" (MTA Nyelvtudományi Intézet, 2016).

A gazdasági és pénzügyi elemzés a gazdasági életben használatos és fontos eljárás, mely a gazdálkodó szervezetek működésének analizálását, összetett szempontrendszer szerinti értékelését jelenti. A gazdasági elemzés a gazdálkodó szervezet fejlesztési, gazdálkodási tevékenységének eredményességi és hatékonysági vizsgálatára, ill. az értékteremtési folyamat összefüggéseinek rávilágítására hivatott. A vezetés olyan, ma már elengedhetetlen eszköze, amely a megfelelő mennyiségü és tartalmú információk feldolgozását és értékelését jelenti, megalapozva ezzel a szervezet döntéshozatali eljárásait.

A gazdasági elemzés eszköztárát bármely gazdálkodó szervezet esetében hasznosítani lehetséges, így vállalatok és vállalkozások, egyesületek, szövetségek, alapítványok, egyéb civil szervezetek, köztestületek és állami szervezetek esetében is, ezek mind képezhetik a gazdasági elemzés tárgyát. A jegyzet a továbbiakban alapvetően a vállalatok területére koncentrálja figyelmét. Szűkebb értelemben véve a gazdasági elemzés tárgyának tekinthetjük mindazon funkcionális és müködési területeket, melyek a vállalkozás értékteremtési láncában megtalálhatóak, így fejlesztési- , beszerzési- , logisztikai- , erőforrás-gazdálkodási- , termelési- , készletezési- , értékesítési- valamint vevőkiszolgálási-tevékenységét is.

\subsection{A gazdasági elemzés célja, szükségessége, döntéshozatali szerepe, feladatai és érintettjei}

Az elemzés a vállalati müködés gyakorlatilag minden szakaszában jelen van. A klasszikus vezetési feladatok egyikeként tekinthetünk rá, mely a probléma-megoldási és döntéshozatali, ill. -végrehajtási folyamatokat végigkíséri. Már a probléma felismerésében is kulcsfontosságúak az elemzés által szolgáltatott információk, hogy egyáltalán tudatosuljon a döntéshozókban, ha probléma-szituáció áll fenn. Ehhez szükségesek olyan előrejelző rendszerek, amelyek idejében képesek az optimálistól eltérő helyzetet jelezni a döntéshozók számára, képesek annak lényegi vonásait megragadni. A probléma felismerését követően fontos annak részletes megértése, öszszetett problémák esetében részproblémákra való bontása és az összetevő részek elemzése.

A problémák megoldása csak akkor lehetséges, ha meghatározott célok állnak a döntéshozók rendelkezésére (melyek lehetnek jól vagy rosszul strukturáltak, azaz könnyen vagy kevésbé könnyen operacionalizálhatók). Ebben a szakaszban kulcsfontosságú elöre meghatározni azokat a mérőszámokat, mérőszámrendszereket, amelyek a probléma-megoldási folyamat értékelése során a végrehajtás eredményességét és hatékonyságát lesznek hivatottak mérni. A célok 
elérése érdekében érdemes több megvalósítható alternatívát is kidolgozni. Az alternatívák közül szükséges kiválasztani azt, amely a döntéshozók szerint előzetesen a leginkább képes elérni a kitüzött célt. Ez csak úgy lehetséges, ha az alternatívák előzetes értékelése is megtörténik a célokhoz rendelt elemzési eszközök segítségével. A kiválasztott alternatíva végrehajtása során nem elég a részfeladatokat elvégezni, majd a végrehajtási folyamat végeztével értékelni, hogy a megvalósítás megfelelö volt-e, hanem folyamatosan monitorozni szükséges a részfeladatokat, azok időbeli ütemezését, a részcélok elérésének és hatékonyságának milyenségét, az erőforrások megfelelő allokációját. Végül természetesen a megvalósítást követően az egész probléma-megoldási folyamatot értékelni, ellenőrizni, elemezni szükséges (2.1. táblázat).

\section{1. táblázat A probléma-megoldási folyamat elemzési igénye}

\begin{tabular}{|c|c|c|}
\hline $\begin{array}{c}\text { Probléma-megoldási fo- } \\
\text { lyamat szakaszai }\end{array}$ & Elemzés általános célja & Módszerek \\
\hline Probléma-felismerés & $\begin{array}{l}\text { Előre jelezni idejekorán az ideá- } \\
\text { listól eltérő müködést. }\end{array}$ & \multirow{4}{*}{$\begin{array}{l}\text { Gazdaságossági számítá- } \\
\text { sok, megelőző elemzések. }\end{array}$} \\
\hline Probléma-megértés & $\begin{array}{l}\text { A probléma okainak feltárása, } \\
\text { részproblémákra bontása. }\end{array}$ & \\
\hline Célmeghatározás & $\begin{array}{l}\text { A jövőbeni értékelés alapjául } \\
\text { szolgáló mutatószámrendszer és } \\
\text { elemzési eszköztár meghatáro- } \\
\text { zása. }\end{array}$ & \\
\hline $\begin{array}{l}\text { Alternatívák kidolgozása } \\
\text { és értékelés }\end{array}$ & $\begin{array}{l}\text { A lehetséges intézkedések követ- } \\
\text { kezményeinek és hatásainak be- } \\
\text { mutatása, optimális alternatíva } \\
\text { kiválasztása. }\end{array}$ & \\
\hline Megvalósítás & $\begin{array}{l}\text { A megvalósítás ütemének nyo- } \\
\text { mon követése, a kitüzött részfel- } \\
\text { adatok eredményes végrehajtásá- } \\
\text { nak ellenőrzése, erőforrások fel- } \\
\text { használásának hatékonysági } \\
\text { elemzése, a kitűzött végcélok } \\
\text { megvalósításának biztosítása. }\end{array}$ & $\begin{array}{l}\text { A végrehajtás szakaszait } \\
\text { jellemző folyamatos infor- } \\
\text { mációk és elemzésük. }\end{array}$ \\
\hline Ellenőrzés, értékelés & $\begin{array}{l}\text { Az előzetesen kitüzött célok el- } \\
\text { érésének ellenőrzése, az esetle- } \\
\text { ges eltérések okainak feltárása, } \\
\text { iránymutatás az ismételt prob- } \\
\text { léma-megoldási folyamat részt- } \\
\text { vevői számára. }\end{array}$ & $\begin{array}{l}\text { Összehasonlítások (terv- } \\
\text { tény), tényezőkre bontás. }\end{array}$ \\
\hline
\end{tabular}

Forrás: saját szerkesztés Birher és mtsai. (2009) alapján

Megalapozott döntéshozatalról csak akkor beszélhetünk, ha a döntéshozók informáltak és tudatában vannak jövőbeni döntéseik következményeivel, vagy legalábbis adott pillanatban előre látható következményeivel. Tehát a gazdasági elemzés feladata az, hogy megfelelő információkkal lássa el a döntés-előkészítőket, a döntéshozókat és a végrehajtókat.

Ennek keretében:

- megalapozza a gazdasági döntéseket;

- kialakítja és működteti a vállalaton belül a felelősségi és érdekeltségi rendszert; 
- elemzi a vállalat és környezete fejlődési tendenciáit;

- elemzi a kitüzött célok elérésének eredményességét és hatékonyságát;

- áttekinti a rendelkezésre álló erőforrások állományát és azok felhasználásának minőségét, az esetlegesen fennálló kapacitás-tartalékokat vagy szük keresztmetszeteket;

- vizsgálja a termelési sorozatnagyságokat;

- elemzi az értékesítési csatornák müködését, a rendelésállományokat és a vevői igénykielégítést;

- vizsgálja a jövedelmezőséget;

- ellenőrzi a gazdálkodás tervszerüségét.

A gazdasági elemzés érintettjei a stakeholder elmélet alapján két csoportra bonthatók. A belső érintettek közé soroljuk a tulajdonosokat, a menedzsereket és az alkalmazottakat, a külső érintettek közé a fogyasztókat, beszállítókat, szövetségeseket, hitelezőket, versenytársakat, állami és önkormányzati intézményeket.

Mindannyiuk más-más érdekekkel és ezáltal információ-igénnyel és -hozzáférési lehetőséggel kapcsolódik a vállalathoz (2.2. táblázat). 
2.2. táblázat A gazdasági elemzés eredményeit felhasználó érintettek

\begin{tabular}{|c|c|c|}
\hline Érintett csoport & Érdekeltség & $\begin{array}{c}\text { Információkhoz való hoz- } \\
\text { záférés lehetôsége }\end{array}$ \\
\hline \multicolumn{3}{|c|}{ Belső érintettek } \\
\hline Tulajdonosok & $\begin{array}{l}\text { A vállalati vezetés minősé- } \\
\text { gének értékelése, a vállalat } \\
\text { értékének meghatározása, a } \\
\text { befektetések megtérülése. }\end{array}$ & \multirow[b]{2}{*}{$\begin{array}{l}\text { Belső információ-források, } \\
\text { kimutatások. }\end{array}$} \\
\hline Menedzsment & $\begin{array}{l}\text { A vállalati folyamatok ered- } \\
\text { ményes alakulása, a vállalat } \\
\text { értékének növelése, megala- } \\
\text { pozott stratégiai és operatív } \\
\text { döntések meghozatala. }\end{array}$ & \\
\hline Alkalmazottak & $\begin{array}{l}\text { Hosszú távon stabil munka- } \\
\text { hely, kiszámítható munka- } \\
\text { körülmények és bérezés. }\end{array}$ & $\begin{array}{l}\text { Részben belső információ- } \\
\text { források, nyilvános informá- } \\
\text { ció-források. }\end{array}$ \\
\hline \multicolumn{3}{|c|}{ Külső érintettek } \\
\hline Fogyasztók, vevők & $\begin{array}{l}\text { Kiszámítható termékminő- } \\
\text { ség és hosszútávon megbíz- } \\
\text { ható kiszolgálás. }\end{array}$ & \multirow{3}{*}{$\begin{array}{l}\text { Mindenki számára nyilvános } \\
\text { információ-források. }\end{array}$} \\
\hline Beszállítók & $\begin{array}{l}\text { Vevői fizetőképesség és lik- } \\
\text { viditás, hosszú távon biztosí- } \\
\text { tott megrendelések. }\end{array}$ & \\
\hline Szövetségesek & $\begin{array}{l}\text { Hosszútávon kiszámítható } \\
\text { együttmüködés és stratégiai } \\
\text { partnerség. }\end{array}$ & \\
\hline Hitelezők & $\begin{array}{l}\text { Befektetett eszközök megté- } \\
\text { rülése, hitelek tervezetten } \\
\text { ütemezett törlesztése. }\end{array}$ & $\begin{array}{l}\text { Hitelszerződés alapján bizto- } \\
\text { sított belső információ-forrá- } \\
\text { sok és nyilvános információ- } \\
\text { források. }\end{array}$ \\
\hline Versenytársak & $\begin{array}{l}\text { A vállalat versenypozíciójá- } \\
\text { nak elemzése, iparági bench- } \\
\text { marking. }\end{array}$ & $\begin{array}{l}\text { Mindenki számára nyilvános } \\
\text { információforrások. }\end{array}$ \\
\hline $\begin{array}{l}\text { Állami és önkormányzati in- } \\
\text { tézmények }\end{array}$ & $\begin{array}{l}\text { Adók, foglalkoztatás, költ- } \\
\text { ségvetési források felhaszná- } \\
\text { lásának eredményessége. }\end{array}$ & $\begin{array}{l}\text { Jogszabály által elöírtak } \\
\text { alapján belső adatforrások és } \\
\text { nyilvános adatforrások. }\end{array}$ \\
\hline
\end{tabular}

Forrás: saját szerkesztés Chikán (2008) alapján 


\subsection{A gazdasági elemzés alapvető módszerei}

Alapvetően három nagy kategóriáját különböztetjük meg a gazdasági elemzés módszereinek: az analizáló-szintetizáló módszert, a következtetéses elemzési módszert és az összehasonlítás módszerét.

Az analízis ill. szintézis két, egymással ellentétes irányú, mégis összetartozó folyamat. Az analízis során a nagy egészet, a rendszerszintű müködést részelemekre, részrendszerekre bontva, egyenként, egymástól elkülönítve vizsgáljuk, célja az alkotóelemek önmagukban történő elemzése (pl. müszaki kapacitáskihasználás felbontása extenzív és intenzív kihasználtságra). A szintézis során az analízis során szétbontott részelemek újbóli összekapcsolása, egységben, egymással való kölcsönhatásukban való vizsgálata történik meg. Ennek révén ismét a rendszer egészének elemzése a cél, de már a részelemek befolyásoló hatásainak ismeretében (pl. valamely gépcsoport üzemképességi mutatójának javulása milyen hatással van a teljes kapacitáskihasználásra).

A következtetéses elemzés módszerei között a szintén egymással ellentétes irányú deduktív és induktív, az analogikus és a hipotézises következtetési módszerek említhetök meg. Deduktív a következtetés akkor, ha a megismerési folyamat az általánostól az egyes elemekig, a részleges irányába halad (pl. a vállalat egészének teljesítményét az egyes részleges teljesítményének alakulásával magyarázzuk), míg induktív akkor, ha a részekből következtetünk az egészre és a részlegesböl vonunk le általános következtetéseket (pl. egyes munkafolyamatok átalakítása hogyan befolyásolja egy vállalati részleg teljes hatékonyságát). Az analóg következtetéses módszer során két vizsgálati elem hasonlóságai alapján, közös jellemzői alapján vonunk párhuzamot köztük és következtetünk egyik elem tulajdonságai alapján a másik müködésére (pl. adott ágazatban müködő jó gyakorlatok - best practice - megvalósítása a saját vállalkozásunk müködésében). A hipotézises következtetési módszer során előfeltételezéssel élünk a vizsgálat tárgyára nézve, mely előfeltételezést aztán statisztikai módszerek segítségével ellenőrizve elvetünk, avagy elfogadunk - a statisztikai sokaság adatai alapján vonunk le általános következtetéseket (pl. selejtarány elemzése sorozatgyártás esetén).

Az összehasonlításos módszer használata során a vizsgált vállalatot vagy annak folyamatait, alrendszereit valamilyen viszonyítási alapul szolgáló referenciával vetjük össze. Az összehasonlítás lehet számszaki adatokon alapuló (kvantitatív) vagy minőségi ismérveken (kvalitatív) alapuló. Fontos, hogy a kvantitatív összehasonlítás során csak azonos módszertannal készített és azonos jelentéstartalommal bíró számadatok összevetése lehetséges. Viszonyítási alapul szolgálhatnak a vállalat saját múltbeli adatai (dinamikus, időbeli összehasonlítás), a korábban kitüzött terveket számszerüsítő mutatók (terv-tény összehasonlítás), másik, az iparágban müködő vállalat, vagy más földrajzi területen müködő vállalat, vagy vállalati részleg adatai (térbeli, területi összehasonlítás). Az összehasonlító elemzések készítése során fontos figyelembe venni, hogy a gazdasági események sosem elszigetelten jelentkeznek és rendszerint nem egyetlen befolyásoló tényező hatására változnak, ezért a vizsgálat során fontos tisztázni azt, hogy mely tényező hatására vagyunk kíváncsiak és mely másik tényezőket kell elkülöníteni egymástól az elemzés során (pl. ilyen torzító hatások lehetnek az árváltozás vagy volumenváltozás hatásai). 


\subsection{A gazdasági elemzés fajtái és eszközei}

A gazdasági elemzés fajtáit elkülöníthetjük többek között az elemzés időtávja, a vezetési folyamatban betöltött célja, tárgya és periodicitása, terjedelme, jellege, közelítésmódja szerint. Ezek eltérő jellemzőkkel írhatók le (2.3. táblázat).

\section{3. táblázat A gazdasági elemzés fajtái}

\begin{tabular}{|c|c|c|}
\hline $\begin{array}{c}\text { Elemzések csoportosítási } \\
\text { szempontjai }\end{array}$ & Elemzés fajtái & Jellemzők \\
\hline \multirow[t]{2}{*}{ Időtáv szerint } & Hosszú távú & $\begin{array}{l}\text { Stratégiai horderejü kérdé- } \\
\text { sekkel és a vállalat jövőké- } \\
\text { pét hosszútávon meghatá- } \\
\text { rozó intézkedésekkel kap- } \\
\text { csolatos elemzések. }\end{array}$ \\
\hline & Rövid távú & $\begin{array}{l}\text { Operatív jellegü folyamatok- } \\
\text { kal, a mindennapos mükö- } \\
\text { dést leíró jellemzőkkel fog- } \\
\text { lalkozó elemzések. }\end{array}$ \\
\hline \multirow{3}{*}{$\begin{array}{l}\text { Vezetői folyamatban betöl- } \\
\text { tött célja és tárgya szerint }\end{array}$} & Feltáró & $\begin{array}{l}\text { Az elégtelen vállalati mükö- } \\
\text { dés okait elemző és feltáró } \\
\text { elemzések. }\end{array}$ \\
\hline & Előkészítő & $\begin{array}{l}\text { A vállalati müködés javítá- } \\
\text { sát szolgáló döntések meg- } \\
\text { hozatalához szükséges infor- } \\
\text { mációkat előállító elemzé- } \\
\text { sek. }\end{array}$ \\
\hline & Megvalósítást ellenőrző & $\begin{array}{l}\text { Végrehajtási szakaszban és a } \\
\text { végrehajtást követően egy- } \\
\text { aránt elvégzett elemzések, } \\
\text { melyek az előzetesen terve- } \\
\text { zett célok elérésének részle- } \\
\text { ges vagy teljes megvalósulá- } \\
\text { sát hivatottak ellenőrizni és } \\
\text { biztosítani. }\end{array}$ \\
\hline \multirow{3}{*}{$\begin{array}{l}\text { Vezetői folyamatban betöl- } \\
\text { tött periodicitása szerint }\end{array}$} & Alkalmi, egyszeri & $\begin{array}{l}\text { Jellemzően egyszeri prob- } \\
\text { léma felmerülésekor, al- } \\
\text { kalmi döntéshozatal előké- } \\
\text { szítésekor. }\end{array}$ \\
\hline & $\begin{array}{l}\text { Rendszertelenül, időszako- } \\
\text { san jelentkező }\end{array}$ & $\begin{array}{l}\text { Bizonyos időszakokban fel- } \\
\text { merülő, előzetesen nem fel- } \\
\text { tétlenül tervezett elemzések. }\end{array}$ \\
\hline & $\begin{array}{l}\text { Rendszeres, időszakosan is- } \\
\text { métlődő }\end{array}$ & $\begin{array}{l}\text { Rendszeresen, tervezetten } \\
\text { felmerülő elemzések (pl. ne- } \\
\text { gyedéves, féléves jelentések } \\
\text { elkészítésekor). }\end{array}$ \\
\hline Terjedelem szerint & Átfogó & $\begin{array}{l}\text { A vállalat teljes egészére ki- } \\
\text { terjedő elemzések. }\end{array}$ \\
\hline
\end{tabular}




\begin{tabular}{|c|c|c|}
\hline & Részleges & $\begin{array}{l}\text { A vállalat egy funkcionális } \\
\text { területére, alrendszerére, fo- } \\
\text { lyamatára kiterjedő elemzé- } \\
\text { sek. }\end{array}$ \\
\hline \multirow{3}{*}{ Jellege szerint } & Leíró & $\begin{array}{l}\text { Az aktuális folyamatokat be- } \\
\text { mutató elemzés. }\end{array}$ \\
\hline & Prognosztizáló & $\begin{array}{l}\text { A jövőre vonatkozó feltáró } \\
\text { elemzés, a várható trendeket } \\
\text { és jövőképeket felvázoló } \\
\text { elemzések. }\end{array}$ \\
\hline & Döntés-előkészítő & $\begin{array}{l}\text { A vállalati döntési folyama- } \\
\text { tot segítő, információkkal el- } \\
\text { látó elemzések. }\end{array}$ \\
\hline \multirow[b]{2}{*}{ Folyamatszemlélete szerint } & $\begin{array}{l}\text { Dinamikus (folyamatszem- } \\
\text { lélet) }\end{array}$ & $\begin{array}{l}\text { Időbeli összehasonlítást tar- } \\
\text { talmazó elemzések. }\end{array}$ \\
\hline & $\begin{array}{l}\text { Statikus (állományi szemlé- } \\
\text { let) }\end{array}$ & $\begin{array}{l}\text { Egy időpontra, aktuális hely- } \\
\text { zetfelmérésre vonatkozó } \\
\text { elemzések. }\end{array}$ \\
\hline \multirow{2}{*}{$\begin{array}{l}\text { Közelítésmódja és a fel- } \\
\text { használt adatok minősége } \\
\text { szerint }\end{array}$} & Gazdasági & $\begin{array}{l}\text { Kizárólag, gazdasági, pénz- } \\
\text { ügyi adatbázisokkal és mu- } \\
\text { tatókkal foglalkozó elemzé- } \\
\text { sek. }\end{array}$ \\
\hline & Müszaki-gazdasági & $\begin{array}{l}\text { A gazdasági és pénzügyi } \\
\text { mutatókat müszaki, terme- } \\
\text { lési és reálmutatókkal kom- } \\
\text { bináló elemzések. }\end{array}$ \\
\hline
\end{tabular}

Forrás: saját szerkesztés Sebes (2013) és Birher és mtsai. (2009) alapján

A gazdasági elemzések elkészítése során különböző mennyiségi és minőségi mutatókat használunk fel következtetések levonására. Ezek a mutatók lehetnek egyszerüen az elsődleges adatgyüjtésből származó abszolút számok vagy az ezekből származtatott, számított és feldolgozott mutatók. A mutatószámok jelentősen összevont, tömörített numerikus kifejezések, amelyek koncentrált formában adnak ismeretet számszerüsíthető, mennyiségi úton bemutatható jelenségekről, ezáltal adatsürítés révén biztosítanak gyorsan áttekintést bonyolult gazdasági folyamatokról.

Az abszolút számok közül használunk egyedi számokat (pl. részvényárfolyam, termékjellemzők), összegeket (pl. teljes dolgozói létszám), különbségeket (pl. fedezeti összeg), ill. középértékeket (módusz, medián).

A statisztikai feldolgozás során képzett mutatók három csoportja a viszonyszámok, az átlagok és az indexek. Ezek kiszámítása egy-egy időszakra vonatkozóan történik meg, azonban annak érdekében, hogy tendenciákat lehessen megállapítani belölük, célszerü öket több egymást követő időszakra is kiszámolni. A mutatók kifejezésre kerülhetnek természetes mértékegységekben (naturáliákban, pl. kg, m, 1 stb.) valamint pénzértékben (pl. Ft, EUR stb.) is. Ennek megfelelően a származtatott mutatók is kifejezhetők ezzel a két móddal, ill. ezek kombinációjával (pl. Ft/l). 
A statisztikából ismert mutatószámok első csoportját a viszonyszámok alkotják, amelyek tulajdonképpen egy hányadost jelentenek, ahol a nevezőben található meg a viszonyítási alapot képező érték.

$$
\text { Viszonyszám }=\frac{\text { Viszonyítandó érték }}{\text { Viszonyítási alap }}
$$

A viszonyszámok képzése során fontos, hogy megfelelő viszonyítási alapot kell kijelölni, amelynek alapjául szolgálhatnak múltbeli évek azonos értékei, ágazati benchmarkértékek, hasonló vállalatok azonos értékei, vagy más területi egységek értékei is (2.4. táblázat).

\section{4. táblázat Viszonyszámok típusai és tartalma}

\begin{tabular}{|c|c|c|c|}
\hline $\begin{array}{l}\text { Viszonyszám } \\
\text { kategóriái }\end{array}$ & Viszonyszám tartalma & Példa & Képlet \\
\hline $\begin{array}{l}\text { Megoszlási vi- } \\
\text { szonyszámok }\end{array}$ & $\begin{array}{l}\text { Az egészen belül egy } \\
\text { bizonyos rész aránya. }\end{array}$ & $\begin{array}{l}\text { Eszközszerkezeti } \\
\text { mutatók, tőke- } \\
\text { szerkezeti muta- } \\
\text { tók }\end{array}$ & $\frac{\text { Vizsgált rész }}{\text { Részek összege }}$ \\
\hline $\begin{array}{l}\text { Dinamikus vi- } \\
\text { szonyszámok } \\
\text { (bázis- ill. lánc- } \\
\text { viszonyszámok) }\end{array}$ & $\begin{array}{l}\text { Időbeli változások mér- } \\
\text { téke, bázisviszonyszá- } \\
\text { mok esetén minden } \\
\text { vizsgált időszak viszo- } \\
\text { nyítási alapja ugyanaz } \\
\text { az időszak, láncvi- } \\
\text { szonyszámok esetén } \\
\text { minden vizsgált időszak } \\
\text { viszonyítási alapja az őt } \\
\text { megelőző időszak. }\end{array}$ & $\begin{array}{l}\text { Adózás utáni } \\
\text { eredmény éven- } \\
\text { kénti alakulása }\end{array}$ & $\frac{\text { Tárgyidőszak adata }}{\text { Bázisidőszak adata }}$ \\
\hline $\begin{array}{l}\text { Teljesítmény-vi- } \\
\text { szonyszámok }\end{array}$ & $\begin{array}{l}\text { A tényleges teljesít- } \\
\text { mény viszonyítása az } \\
\text { elérni kívánt vagy opti- } \\
\text { mális teljesítményhez. }\end{array}$ & $\begin{array}{l}\text { Tényleges és ter- } \\
\text { vezett árbevétel } \\
\text { aránya }\end{array}$ & $\frac{\text { Tényleges teljesítményadat }}{\text { Tervezett teljesíményadat }}$ \\
\hline $\begin{array}{l}\text { Koordinációs vi- } \\
\text { szonyszámok }\end{array}$ & $\begin{array}{l}\text { Részadatok egymáshoz } \\
\text { való viszonya. }\end{array}$ & Tőkemultiplikátor & $\frac{\text { Részadat }}{\text { Részadat }}$ \\
\hline $\begin{array}{l}\text { Területi össze- } \\
\text { hasonlító vi- } \\
\text { szonyszámok }\end{array}$ & $\begin{array}{l}\text { Azonos tartalmú adatok } \\
\text { különböző földrajzi te- } \\
\text { rületeken vagy pl. telep- } \\
\text { helyeken mért aránya. }\end{array}$ & $\begin{array}{l}\text { Más városokban } \\
\text { lévő termelő egy- } \\
\text { ségek erőforrás- } \\
\text { felhasználásának } \\
\text { összehasonlítása }\end{array}$ & $\frac{\text { Elemzendő területi egység }}{\text { Referencia területi egység }}$ \\
\hline $\begin{array}{l}\text { Intenzitási vi- } \\
\text { szonyszámok }\end{array}$ & $\begin{array}{l}\text { Két különböző típusú } \\
\text { statisztikai adat nagysá- } \\
\text { gának aránya. }\end{array}$ & $\begin{array}{l}\text { Munkatermelé- } \\
\text { kenység, termés- } \\
\text { átlag }\end{array}$ & $\frac{\text { Egyik fajta adat }}{\text { Másik fajta adat }}$ \\
\hline
\end{tabular}

Forrás: saját szerkesztés Himber és mtsai (2011) alapján 
Sürün használatos mutatók közé tartoznak az átlagok (számított középértékek), amellyel egy statisztikai sokaság összességét igyekszünk leírni. Gyakran használatosak a helyzeti középértékek is, melyek a sorba állított sokaság értékeinek elhelyezkedése alapján kerülnek meghatározásra.

Az átlagok képleteinek felírásakor használt rövidítések általában az alábbiak:

- n: a vizsgált egységek darabszáma,

- i: az adott vizsgálati egység sorszáma,

- $\mathrm{X}_{\mathrm{i}}$ : az i-edik vizsgálati egység értéke

- $\mathrm{f}_{\mathrm{i}}$ : az előforduló i-edik érték gyakorisága, súlya

- $\bar{x}$ : az átlagérték valamely fajtája.

A számított középértékek közül leggyakrabban használt a számtani átlag, amely lehet egyszerü vagy súlyozott. Az egyszerü számtani átlag esetében minden érték egyszer fordul elő. Akkor használatos, ha az átlagolandó értékek egyenletesen változnak (pl. munkatársak átlagos életkorának meghatározása).

$$
\overline{\mathrm{x}}=\frac{\sum_{\mathrm{i}=1}^{\mathrm{n}} \mathrm{X}_{\mathrm{i}}}{\mathrm{n}}
$$

Ezzel szemben a súlyozott számtani átlag esetében azt is figyelembe vesszük, hogy egy-egy érték többször is előfordul. Jellemzően akkor használatos, ha az egyes megfigyelési időpontok között nem ugyanannyi idő telik el és az eltelt napokat használjuk fel súlyokként (pl. szezonálisan változó értékek esetében).

$$
\bar{x}=\frac{\sum_{i=1}^{n} f_{i} X_{i}}{\sum_{i=1}^{n} f_{i}}
$$

Azonos időtartamú adatok, hosszabb időszakra vonatkozó értékelés esetén használatos a kronologikus átlag. Ennek képletében az első és az utolsó időszak adatainak fele szerepel csak, ennek megfelelően a vizsgált időszakok számánál eggyel kevesebb értékkel történik az osztás (pl. készletállomány vizsgálata).

$$
\overline{x_{k}}=\frac{\frac{X_{0}}{2}+X_{1}+\cdots+X_{n-1}+\frac{X_{n}}{2}}{n-1}
$$

Amennyiben értelmezhető az egyes átlagolandó értékek reciprok-értéke, akkor harmonikus átlag számítására kerülhet sor (pl. egy termék előállításának átlagos időtartama).

$$
\overline{\mathrm{x}_{\mathrm{h}}}=\frac{\mathrm{n}}{\sum_{\mathrm{i}=1}^{\mathrm{n}} \frac{1}{\mathrm{X}_{\mathrm{i}}}}
$$

Ha többször is előfordul egy átlagolandó érték, akkor számítható a súlyozott harmonikus átlag is (pl. átlagár meghatározása). 


$$
\overline{\mathrm{x}_{\mathrm{h}}}=\frac{\sum_{\mathrm{i}=1}^{\mathrm{n}} \mathrm{f}_{\mathrm{i}}}{\sum_{\mathrm{i}=1}^{\mathrm{n}} \frac{\mathrm{f}_{\mathrm{i}}}{\mathrm{X}_{\mathrm{i}}}}
$$

A számtani átlagokon felül mértani (geometriai) átlagok is használhatóak, amennyiben az átlagolandó értékek szorzatának van jelentéstartalma (pl. a láncviszonyszámok alapján a fejlödés átlagos növekedési üteme).

$$
\overline{x_{g}}=\sqrt[n]{\prod_{i=1}^{n} X_{i}}
$$

A mértani átlag speciális esete a négyzetes (kvadratikus) mértani átlag, amelyet elsősorban a szóródás számításánál szokás felhasználni.

$$
\overline{\mathrm{x}_{\mathrm{q}}}=\frac{\sum_{\mathrm{i}=1}^{\mathrm{n}} \mathrm{X}_{\mathrm{i}}^{2}}{\mathrm{n}}
$$

Az átlagok használata önmagukban véve sok esetben félrevezető lehet, ezért szokás a sokaság szórását is egyúttal feltüntetni az átlagértékek mellett (pl. ha vannak szélsőségesen kiugró értékek a sokaságon belül, akkor azok ,elhúzhatják” az átlagot). Az átlagokból mélyreható következtetést az alacsony szórással rendelkező sokaságok esetében lehet igazán levonni. A szórás mutatószámai - melyeket használatunk pl. egy ágazat vállalkozásainak árbevételeinek értékelésére - közül a legegyszerűbb a szórás terjedelme, azaz a sokaságban előforduló legmagasabb és legalacsonyabb érték különbözete.

$$
\mathrm{R}=\mathrm{x}_{\max }-\mathrm{x}_{\min }
$$

Az átlagos (abszolút) eltérés az egyes vizsgálati egyedeknek az átlagtól való eltérését átlagolja.

$$
\bar{\delta}=\frac{\sum_{i=1}^{\mathrm{n}} \mathrm{f}_{\mathrm{i}}\left(\mathrm{X}_{\mathrm{i}}-\overline{\mathrm{X}}\right)}{\sum_{\mathrm{i}=1}^{\mathrm{n}} \mathrm{f}_{\mathrm{i}}}
$$

Az átlagos négyzetes eltérés (amelyet valójában szórásnak nevezünk) kiküszöböli az átlagtól való eltérés pozitív vagy negatív irányának hatását.

$$
\sigma=\sqrt{\frac{\sum_{i=1}^{n} f_{i}\left(X_{i}-\bar{X}\right)^{2}}{\sum_{i=1}^{n} f_{i}}}
$$

A szóródási együttható azt mutatja meg, hogy a szóródás az átlagnak mekkora része. Értéke minél kisebb, annál inkább megbízható az átlagokból való következtetés. 


$$
\mathrm{V}=\frac{\sigma}{\overline{\mathrm{x}}}
$$

A helyzeti középértékek elsősorban a statisztikai sokaság leírására használatosak. Ide tartozik a medián (amely az az érték a sokaságon belül, amihez képest pont ugyanannyi kisebb, mint nagyobb érték található meg a sokaságban) illetve a módusz, amely a legnagyobb gyakorisággal előforduló egyedi érték a sokaságon belül (pl. egy vállalkozás munkavállalóinak keresetét szokás ezekkel a mutatókkal értékelni).

A harmadik főbb statisztikai mutatócsoport az indexek csoportja, melyeket elsősorban az idősoros elemzések esetében használunk, de használatos területi összehasonlítások esetén is. Jellemző az alkalmazásuk akkor, ha a különböző mértékegységek miatt a vizsgált adatok nem összesíthetőek, de összehasonlításukra mégis szükség van. Az indexek három tipikus formája az értékindexek, az árindexek és a volumenindexek.

Az indexek képleteinek felírásakor használt rövidítések:

- $\mathrm{q}_{0}=$ termék mennyisége a bázisidőszakban

- $\mathrm{q}_{1}=$ termék mennyisége a tárgyidőszakban

- $\mathrm{p}_{0}=$ termék ára a bázisidőszakban

- $\mathrm{p}_{1}=$ termék ára a tárgyidőszakban

Az értékindex az összesített termelési árbevétel változását mutatja meg, aggregálva az értékesítési tevékenységbe tartozó összes terméket, azok mennyiségeit és árait. Változásában pedig egyaránt szerepet játszik a termékek árainak és mennyiségeinek változása is.

$$
\mathrm{I}_{\mathrm{v}}=\frac{\sum \mathrm{q}_{1} \mathrm{p}_{1}}{\sum \mathrm{q}_{0} \mathrm{p}_{0}}
$$

Az értékindex változásait okozó hatások felbontására hivatott az árindex és a volumenindex, amelyek a termékek árainak és mennyiségeinek változásait külön-külön számszerüsítik.

Az árindexek (melyek a vizsgált termékek árváltozási hatásait számszerüsítik) két fajtája a bázisidőszaki (Laspeyres) és a tárgyidőszaki (Paasche) súlyozású index.

$$
\begin{aligned}
\mathrm{I}_{\mathrm{p}}^{\mathrm{L}} & =\frac{\sum \mathrm{q}_{0} \mathrm{p}_{1}}{\sum \mathrm{q}_{0} \mathrm{p}_{0}} \\
\mathrm{I}_{\mathrm{p}}^{\mathrm{P}} & =\frac{\sum \mathrm{q}_{1} \mathrm{p}_{1}}{\sum \mathrm{q}_{1} \mathrm{p}_{0}}
\end{aligned}
$$

Azonos módon a volumenindexek (melyek a vizsgált termékek mennyiségváltozásból eredő hatásait számszerüsítik) is ugyanezen két súlyozási szempont szerint elkészíthetők.

$$
\begin{aligned}
\mathrm{I}_{\mathrm{q}}^{\mathrm{L}} & =\frac{\sum \mathrm{q}_{1} \mathrm{p}_{0}}{\sum \mathrm{q}_{0} \mathrm{p}_{0}} \\
\mathrm{I}_{\mathrm{q}}^{\mathrm{p}} & =\frac{\sum \mathrm{q}_{1} \mathrm{p}_{1}}{\sum \mathrm{q}_{1} \mathrm{p}_{1}}
\end{aligned}
$$


Az érték-, ár- és volumenindexek összefüggése szorzat formájában adódik (az értékindex az árindex és a volumenindex szorzata).

$$
\mathrm{I}_{\mathrm{v}}=\mathrm{I}_{\mathrm{p}} \times \mathrm{I}_{\mathrm{q}}
$$

Az értékindex felbontásánál már láttuk azt, hogy fontos az összehasonlítások során az eltérések okainak részletesebb feltárása és részletekre bontása. Az eltérések tényezőkre bontása során standardizáljuk az adatokat (azaz azonos mérési skálára hozzuk őket) és az egyes tényezők hatásait egymástól elkülönítetten, több lépésben vizsgáljuk. Ennek módszerei a láncbehelyettesítés, az abszolút különbözetek és a százalékos különbözetek módszerei, melyek akkor használhatóak, ha az egyes tényezők között szorzat jellegü kapcsolat van.

A termelési érték (TÉ) változásán szemléltetve a kapacitásváltozások (k), termelékenységi változások (q) ill. árváltozások (p) hatását az alábbiakban lehet összefoglalni a három módszer különbségeit és hasonlóságait.

A teljes termelési érték változása az alábbi képlettel írható le.

$$
\Delta \mathrm{TÉ}=\mathrm{k}_{1} \mathrm{q}_{1} \mathrm{p}_{1}-\mathrm{k}_{0} \mathrm{q}_{0} \mathrm{p}_{0}
$$

A láncbehelyettesítés módszerének alkalmazása során az egyes tényezők változásának hatását úgy vesszük figyelembe, hogy egymás után számítjuk ki az egyes termelési tényezők változásának következményeit, majd a követő változások hatásainak számszerüsítésénél már ezeket a megváltoztatott értékeket használjuk fel.

A kapacitásváltozás hatása:

$$
\Delta \mathrm{TÉ}_{\mathrm{k}}=\mathrm{TE} \mathrm{E}_{1 \mathrm{k}}-\mathrm{TÉ} \mathrm{E}_{0}=\mathrm{k}_{1} \mathrm{q}_{0} \mathrm{p}_{0}-\mathrm{k}_{0} \mathrm{q}_{0} \mathrm{p}_{0}
$$

A termelékenység változása:

$$
\Delta \mathrm{TE}_{\mathrm{q}}=\mathrm{TE}_{1 \mathrm{q}}-\mathrm{TE} \mathrm{E}_{1 \mathrm{k}}=\mathrm{k}_{1} \mathrm{q}_{1} \mathrm{p}_{0}-\mathrm{k}_{1} \mathrm{q}_{\mathrm{o}} \mathrm{p}_{0}
$$

Az árváltozás hatása:

$$
\Delta \mathrm{TE}_{\mathrm{p}}=\mathrm{TE} \hat{E}_{1 \mathrm{p}}-\mathrm{TE} \hat{E}_{1 \mathrm{q}}=\mathrm{k}_{1} \mathrm{q}_{1} \mathrm{p}_{1}-\mathrm{k}_{1} \mathrm{q}_{1} \mathrm{p}_{0}
$$

Összességében igaz, hogy $\Delta \mathrm{TÉ}=\Delta \mathrm{TÉ}_{\mathrm{k}}+\Delta \mathrm{TÉ}_{\mathrm{q}}+\Delta \mathrm{TE} \mathrm{E}_{\mathrm{p}}$.

Könnyebben áttekinthető módszer a láncbehelyettesítésnél az abszolút különbözetek módszere, amelynél az egyes tényezők különbözeteit használjuk fel, ugyanakkor tartalmi különbség nincsen (tulajdonképpen az előző képletekből kiemelés történik meg).

A kapacitásváltozás hatása:

$$
\Delta \mathrm{TÉ}_{\mathrm{k}}=\mathrm{TÉ}_{1 \mathrm{k}}-\mathrm{TE} \mathrm{E}_{0}=\left(\mathrm{k}_{1}-\mathrm{k}_{0}\right) \mathrm{q}_{0} \mathrm{p}_{0}
$$

A termelékenység változása:

$$
\Delta \mathrm{TE}_{\mathrm{q}}=\mathrm{TE} \hat{E}_{1 \mathrm{q}}-\mathrm{TE} \hat{E}_{1 \mathrm{k}}=\left(\mathrm{q}_{1}-\mathrm{q}_{0}\right) \mathrm{k}_{1} \mathrm{p}_{0}
$$


Az árváltozás hatása:

$$
\Delta \mathrm{TE}_{\mathrm{p}}=\mathrm{TE} \hat{E}_{1 \mathrm{p}}-\mathrm{TE} \mathrm{E}_{1 \mathrm{q}}=\left(\mathrm{p}_{1}-\mathrm{p}_{0}\right) \mathrm{k}_{1} \mathrm{q}_{1}
$$

A százalékos különbözetek módszerénél az egyes tényezők százalékos változásait használjuk fel a kalkulációban (százalékos értékek az adott tényező tárgyévi értékének és bázisévi értékének hányadosát jelentik).

A kapacitásváltozás hatása:

$$
\Delta \mathrm{TE}_{\mathrm{k}}=\mathrm{k} \% \times \mathrm{q}_{0} \mathrm{p}_{0}
$$

A termelékenység változása:

$$
\Delta \mathrm{TE}_{\mathrm{q}}=\mathrm{q} \% \times \mathrm{k}_{1} \mathrm{q}_{\mathrm{o}} \mathrm{p}_{0}
$$

Az árváltozás hatása:

$$
\Delta \mathrm{TE}_{\mathrm{p}}=\mathrm{p} \% \times \mathrm{k}_{1} \mathrm{q}_{1} \mathrm{p}_{0}
$$

A statisztika eszköztárából használatos módszerek még a rugalmassági együtthatók (adott mutató hány százalékkal változik egy másik mutató 1 százalékos változásának hatására), a trendelemzés (lineáris, exponenciális, degresszív, polinomiális, logisztikus trendek adott idősor időbeli változásának elemzésére) és a korrelációszámítás (két metrikus mérési skálájú változó öszszefüggésének, együttes mozgásának vizsgálatára). Ezek módszertanát a megfelelő statisztikai kurzusokon részletesen tárgyalják.

\section{Forrásjegyzék}

1) Béhm, I. (1998). Gazdasági-pénzügyi ismeretek. Budapest: Perfekt Gazdasági Tanácsadó, Oktató és Kiadó Zrt.

2) Birher, I., Pucsek, J., Sándor, L., Sztanó, I. (2009). Vállalkozások tevékenységének gazdasági elemzése. Budapest: Perfekt Gazdasági Tanácsadó, Oktató és Kiadó Zrt.

3) Chikán, A. (2008). Vállalatgazdaságtan. Budapest: Aula Kiadó

4) Harrington, D. R. (1995). Vállalatok pénzügyi elemzése. Budapest: Kossuth Kiadó.

5) Himber, P., Kapásiné Buza, M., Kovácsné Soós, P. (2011). Számvitelelemzés II. Budapest: Perfekt Gazdasági Tanácsadó, Oktató és Kiadó Zrt.

6) Jacobs, O. H., Oestreicher, A. (2000). Mérlegelemzés. Budapest: Kossuth Kiadó.

7) MTA Nyelvtudományi Intézet. (2016). A magyar nyelv értelmező szótára (2. kötet). Budapest: Arcanum Adatbázis Kft. Letöltés dátuma: 2019. 03. 10., forrás: https://www.arcanum.hu/hu/online-kiadvanyok/Lexikonok-a-magyar-nyelv-ertelmezo-szotara-1BE8B/?list=eyJmaWx0ZXJzIjogeyJNVSI6IFsiTkZPX0xFWF9MZXhpa29ub2tfMUJFOEIiXX0sICJxdWVyeSI6ICJlbGVtelx1MDB1OXMifQ

8) Sebes, J. (2013). Elemzés - Vállalati elemzés - Mérlegelemzés. Budapest: Aura Kiadó. 
9) Takács, I. (2008). A vállalkozások elemzése. In A. Nábrádi, T. Pupos, K. Takácsné György, Üzemtan I. (old.: 197). Budapest: Szaktudás Kiadó.

10) Zaicz, G. (Szerk.). (2006). Etimológiai szótár - Magyar szavak és toldalékok eredete (első. kiad.). Budapest: Tinta Könyvkiadó.

11) Zéman, Z., Béhm, I. (2016). A pénzügyi menedzsment controll elemzési eszköztára. Budapest: Akadémiai Kiadó. 


\section{Számviteli beszámolók szerepe és jelentősége}

Egy vállalkozásnak sokféle célja lehet, ezeket többféle megközelítésben is csoportosíthatjuk. Nézzünk pár példát: hosszú távú fennmaradás, megfelelően gazdaságos és megfelelő színvonalú tevékenység biztosítása, profit és annak maximalizálása, vagyonmegtartás és növelés, innováció, stb. E célok nem minden vállalatnál léteznek egyszerre, de ezek a legfőbb célok. Röviden megfogalmazva, a vállalkozás legfőbb célja fogyasztói igények kielégítése haszonszerzés mellett. Kicsit hosszabban az, hogy egy vállalat egy adott térben és időben létező fogyasztói igényt a konkurenciánál jobban elégítsen ki, összefüggésben a saját céljaival. Ez természetesen értékteremtő folyamatokon keresztül zajlik, melynek végeredménye mindig az érték.

Ahogy már említettük, a gazdasági elemzéshez sok releváns, azaz számunkra valóban értékes információra lesz szükség. Természetesen az sem mindegy, hogy ki nézi, ki fogja felhasználni ezeket, azaz nem feledkezhetünk meg a stakeholderek-ről sem. A vállalat tevékenységei során számos szereplővel kerül kapcsolatba, akik eltérő információkat kérnek és kapnak a vállalattól. Ebben a kommunikációs folyamatban kiemelkedő szerepe van a tulajdonosoknak és a menedzsmentnek, de fontosak a külső érintettek is, akik különböző területekről, különböző okokból lépnek kapcsolatba a céggel, így eltérő információkra van szükségük ahhoz, hogy megfelelő döntés hozzanak.

A tulajdonosok kíváncsiak lesznek arra, hogy mennyire stabil a vállalkozás gazdasági háttere, a gyarapodik-e a vagyon, és persze, hogy mekkora osztalékra számíthatnak. A befektetők kockázataikat szeretnék csökkenteni azáltal, hogy információt kérnek, érdemes-e befektetni ebbe a vállalkozásba. A hitelezők természetesen kamatostól szeretnék visszakapni korábban folyósított hiteleiket, az üzleti partnerek szeretnék tudni, hogy érdemes-e nekünk szállítani, ki tudjuk-e majd fizetni, vagy éppen a vevők kíváncsiak arra, hogy a jövőben is életképes lesz-e a kapcsolat, tudunk-e nekik termékeket gyártani, vagy éppen szolgáltatásokat nyújtani.

Ezeknek az információknak az egyik legfontosabb forrása a számvitel, a számviteli információrendszer. Ez az információrendszer nagy részben a számviteli törvényen alapul, illetve az előírásoknak megfelelően elkészített analitikákból, szintetikákból, beszámolóból áll össze, kiegészítve a vezetői számvitellel és controllinggal. Ez a törvény olyan számviteli szabályokat tartalmaz, melyek egyrész EU kompatibilisek, figyelemmel vannak a nemzetközi számviteli elvekre, illetve ezek alapján megbízható és valós összképet biztosító tájékoztatás nyújtható a törvény hatálya alá tartozó - vállalkozások jövedelemezőségi, vagyoni és pénzügyi helyzetéröl, és jövőbeli terveiről. Úgy is mondhatjuk, hogy a vállalkozásoknál bekövetkezett változások, gazdasági események megfigyelését, mérését, feljegyzését, ellenőrzését és elemzését végzi el. A törvény célja a többszöri újrakodifikálás után sem változott, továbbra is a megbízható, valós kép kialakítása és biztosítása a vállalkozás vagyoni, pénzügyi és jövedelmi helyzetéről. „,Számvitel fogalma tehát a gazdasági események nyomonkövetése, rögzített rendszerben való regisztrálása, és információnyújtás külső és belső érintettek számára.” (Polyák, 2006). Ez a számviteli alapelvekkel, az azokra épített szabályoknak az érvényre juttatásával és a számviteli politikával valósítható meg. 
A törvény hatálya kiterjed a gazdaság minden olyan résztvevőjére, amelynek müködéséről a nemzetgazdaság más szereplői tájékoztatást igényelnek (a gazdálkodók), de nem terjed ki az egyéni vállalkozóra, a polgári jogi társaságra, az építőközösségre, továbbá a külföldi székhelyü vállalkozás magyarországi kereskedelmi képviseletére (Parádi-Dolgos, Polyák, Varga, 2013, Béhm, 1998, 2000. évi C. törvény a számvitelről).

A számvitelről szóló törvény folyamatosan módosul, melyek kisebb-nagyobb mértékben érintik a gazdasági élet többi részét is, például, hogy a nemzetközi szabályozásokkal összhangban már nincsenek rendkívüli tételek, a mérleg szerinti eredmény helyett az adózott eredmény szerepel a kimutatásokban, az egyéb ráfordítások között kell elszámolni az üzletág értékesítésének veszteségét. Továbbá, a törvénybe bekerült az üzletág fogalma, a konszolidálásba bevont vállalkozások a konszolidálásba történő bevonáskor is megváltoztathatják üzleti évüket akkor is, ha még nem rendelkeznek három lezárt üzleti évi beszámolóval, hatályos jogszabályi rendelkezések alapján a hitelintézetek a nem magánszemély ügyfeleiknek negatív kamatot is felszámíthatnak, illetve 2019. január 1-től megváltozott a cash flow-kimutatás tagolása is, stb.

A számviteli törvény kötelezően elöírja a költségek elszámolását, de a különféle költségnyilvántartások rendszerét a vállalkozás alakítja ki. Ennek a költségelszámolásnak a célja nem más, mint információnyújtás a stekaholdereknek a költségek alakulásáról, azaz az inputok (erőforrások felhasználások) és outputok (termékek, szolgáltatások létrehozásának elszámolása) a költségelszámolása. Az elszámolások megszervezésével együtt meg kell határozni a felelösségi köröket is, ezek vezetőit költséggazdáknak hívjuk. Ilyenek lehetnek például a HR, marketing, termelési stb. költséggazdák.

A számvitel tulajdonképpen egy módszertan, mely egyrészt elméleti kérdésekkel foglalkozik, másrészt a számvitel müködtetése során alkalmazott módszerekkel, az a gyakorlati tevékenység, amelynek eredményeként a gazdálkodó szervezetek vagyoni, pénzügyi és jövedelmi hely-

zetéről valósághü, objektív képet kapunk. Úgy is mondhatjuk, hogy nem más, mint azoknak az okmányoknak, dokumentumoknak, adatoknak az összessége, amelyek a gyakorlati tevékenység során létrejönnek, összességében a gazdálkodó szervezetek müködését bemutató információs rendszer.

A számviteli törvényben megfogalmazott alapelvek és értékelések alapján minden gazdálkodónak ki kell alakítania a számviteli politikáját. Ez nem más, mint a törvény végrehajtásához szükséges eszközök és módszerek összessége, melyek hatással vannak a cég gazdasági helyzetére, befolyásolják annak eredményét.

\subsection{A számviteli politikával szemben támasztott követelmények}

- legyen a vállalkozásra szabott, tükrözze annak tevékenységét,

- elégítse ki a stakeholderek információigényét,

- teljes körüen terjedjen ki mindenre,

- legyen egyértelmü, pontos és időszerü, azaz aktuális,

- egyben legyen következetes is, relatíve legyen állandó, nem szabad sokszor változtatni. 
Ennek keretében több mindent is rögzíteni kell, a teljesség igénye nélkül nézzük meg a legfontosabbakat:

Általános jellegü elöírások:

- beszámoló fajtája,

- mérlegkészítés időpontja,

- üzleti év meghatározása (ha eltér a naptári évtől),

- mérleg, eredménykimutatás formája, összevont sorai,

- kiegészítő melléklet, valamint a számlarend és bizonylati szabályzat tartalma,

- könyvvezetés pénzneme.

Eszközökkel és kötelezettségekkel kapcsolatban:

- amortizációs politika,

- árfolyamok, követelések minősítése,

- készletek nyilvántartása,

- saját termelésủ készletek és a piaci értéken történő értékelések,

- időbeli elhatárolások és céltartalékok képzése, tartalma.

Lényegesség és költség/haszon elv alkalmazásával kapcsolatban:

- jelentős összegű hiba meghatározása,

- egyösszegü értékcsökkenés, terven felüli értékcsökkenés, maradványérték meghatározása,

- követelések értékvesztésének elszámolása,

- fajlagosan kisösszegü készletek, követelések,

- cégvásárlás esetén az eszközök reális értékének meghatározása, stb.

Ami még szintén fontos, hogy a számviteli politika keretében különböző szabályzatokat kell elkészíteni, melyek tartalmazzák az eszközök; és források, értékelési és leltározási módját, az önköltségszámítás és a pénzkezelés módszerét.

Egy üzleti év zárását követően minden gazdálkodónak - akit a számviteli törvény erre kötelez - leltárral és könyvvezetéssel alátámasztott beszámolót kell készítenie, mely bemutatja az adott cég vagyoni, jövedelmi és pénzügyi helyzetét. (Csak egy pár példát említve, a törvény nem terjed ki az egyéni vállalkozóra, építőközösségre, vagy a külföldi székhelyű vállalkozás magyarországi kereskedelmi képviseletére.) A vállalkozás gazdálkodásnak átfogó, komplex elemzésére e beszámoló felhasználásával kerülhet sor.

Az elkészült beszámoló számos belső és külső érintettnek nyújthat hasznos információt, például a tulajdonosoknak, hogy korábbi befektetési döntésük megalapozott volt-e, milyen a cég jövedelemtermelö képessége, a hitelezőknek, hogy biztonságos-e az adott kölcsön visszafizetése (törlesztőrészletek és kamatfizetés tekintetében), meglévő és potenciális partnereknek (vevők, szállítók), hogy az üzleti kapcsolat biztonságos-e, vagy a dolgozók és a menedzsment számára a stabilitás, fejlődés szempontjából. 
Az információk részletezettségét és mélységét, valamint az elemzési lehetőségeket nagyban befolyásolja a beszámoló formája.

\subsection{A beszámoló formái, részei és tartalma}

A vállalkozások beszámolója lehet:

- éves beszámoló,

- egyszerüsített éves beszámoló,

- mikrogazdálkodói egyszerüsített éves beszámoló,

- egyszerüsített beszámoló, és

- összevont (konszolidált) beszámoló.

Ezen beszámolók részei:

A mérleg, mely a vállalkozás vagyoni helyzetét mutatja meg egy dedikált napon, alapesetben az üzleti év utolsó napjára vonatkoztatva. A mérleg két változatban készíthető, ezt a vállalkozó választja ki, választását a számviteli politikában rögzíteni kell. A két változat közötti legfontosabb eltérés, hogy míg az „A” változatban az eszközök és források a mérleg két oldalán elkülöníthetően mutathatók ki (mérlegszerü elrendezés, a két oldal föösszegének egyeznie kell) és az eszközök azok likviditása (pénzzé tehetősége) szerint növekvő sorrendben láthatóak, míg a forrásoknál a fordított lejárati (esedékességi) sorrend érvényesül, addig a B változat esetén lépcsőzetes elrendezéssel találkozunk, mely részben finanszírozási szemléletü (kiemeli az egy éven belüli kötelezettségeket, a nettó forgótökét és a müködő tőkét). Ez a fajta mérleg nem tartalmaz föösszeg sorokat, hanem olyan speciális összegzéseket, melyek elemző számításokhoz szükségesek.

Az eredménykimutatás egy adott időszakra - általában egy üzleti év - vonatkozóan törvény szerinti szerkezetben és összevontan tartalmazza a tárgyévi adózott eredmény levezetését. Tulajdonképpen az árbevételből indulunk ki, láthatjuk az eredményre ható tényezőket (bevételek, költségek, ráfordítások). Eredménykategóriákon keresztül (üzemi, üzleti tevékenység eredménye, pénzügyi mủveletek eredménye, adótás előtti eredmény és az adózott eredmény) részletezi azt, és kétféle változatban készíthető a vállalkozó választása szerint. Ez a két eljárás az összköltség eljárással készített és a forgalmi költség eljárással készített eredménykimutatás. Az alapvető különbség a saját teljesítményekkel kapcsolatos erőforrások felhasználásának megjelenítésében van. Az összköltség eljárással készített eredménykimutatás költségei a felhasznált erőforrások pénzben kifejezett értékét mutatják (pl. anyagköltség, bérköltség stb.), a forgalmi eljárással késztett viszont azt mutatja meg, hogy az árbevétel érdekében közvetlenül vagy közvetettet merültek-e fel ezek, így a két eljárás csak az üzemi, üzleti tevékenység eredményének meghatározásában tér el, utána a kétféle séma megegyezik.

(E jegyzet további számviteli részletezésre nem vállalkozik, a sémákat, további jellegzetességeket, elöírásokat stb. lásd a számviteli tanulmányokban.) 
A kiegészítő melléklet célja olyan további információk rendelkezésre bocsájtása, mely hozzájárul a további részletes elemzéshez, abból a célból, hogy a beszámoló a gazdálkodó vagyoni, pénzügyi és jövedelmi helyzetéről valóban pontos, megbízható és valós képet mutasson. (A Szerzők fontosnak tartják e beszámolórész - és az üzleti jelentés - részletesebb kifejtését, bemutatását, pontosan az elemzési tevékenység miatt, ezt lásd később.)

Térjünk vissza a beszámoló fajtáira, hiszen - ahogy említettük - nagyban befolyásolják az elemzési lehetőségeket, tekintsük át röviden az erre vonatkozó elöírásokat.

Alapszabály, hogy minden kettős könyvvezetést vezető vállalkozásnak éves beszámolót kell készítenie, de bizonyos feltételek fennállása esetén készíthet egyszerüsített éves beszámolót is. Egyszerüsített éves beszámolót abban az esetben készíthet, ha a mérleg fordulónapján a következő 3 mutatóérték közül kettő nem haladja meg a határértéket:

- mérlegföösszeg az 1200 millió forintot,

- éves nettó árbevétel az 2400 millió forintot,

- az üzleti évben foglalkoztatottak száma az 50 föt.

Amennyiben a vállalkozó ezt a beszámolót választja, üzleti jelentést nem kell készítenie, a mérleg az eszközöket és forrásokat, az eredménykimutatás a bevételeket és ráfordításokat öszszevontan, kevésbé részletezetten mutatja be. Viszont határértéktől függetlenül ezt nem készítheti nyilvánosan müködő részvénytársaság, anyavállalat, közérdeklődésre számot tartó gazdálkodó (pl. tőzsde, biztosító) és olyan vállalkozó melynek értékpapírjait tőzsdén forgalmazzák, vagy arra készül.

Ezt a beszámolót a kormányrendeletben megfogalmazottoknak (398/2012. (XII. 20.) Kormányrendelet a mikrogazdálkodói egyszerüsített éves beszámolóról) megfelelően mikrogazdálkodói beszámoló formájában is elkészítheti a vállalkozás, ha a mérleg fordulónapján a következő 3 mutatóérték közül kettő nem haladja meg a határértéket:

- mérlegföösszeg a 100 millió forintot,

- éves nettó árbevétel a 200 millió forintot,

- az üzleti évben foglalkoztatottak száma a 10 föt.

Az értékekből is látható, hogy a kettős könyvvitelt választó legkisebb cégek, egyéni cégek, egyéb vállalkozók választhatják, lényege az egyszerübb szabályrendszer és számviteli politikát, kiegészítő mellékletet sem kell készíteni, ám határértékéktől függetlenül ezt nem készítheti befektetési vállalkozás és pénzügyi holdingvállalkozás.

Egyszeres könyvvitellel alátámasztott egyszerüsített beszámolót az a gazdálkodó készíthet, akinek a számviteli törvény ezt megengedi (pl. társasház, alapítvány, egyesület, iskolaszövetkezet, erdőbirtokossági társulat - azaz vállalkozások nem készíthetik), ez a beszámoló egyszerüsített mérlegből és eredménylevezetésböl áll. Az elnevezésekből is látható, hogy sokkal rövidebb, sokkal kevésbé részletes tételekből állnak e beszámolórészek. (2004. január 1-től a vállalkozásoknak át kellett térni az egyszerüsített éves beszámolóra.) 
Összevont (konszolidált) éves beszámolót az a gazdálkodó köteles készíteni, amely egy vagy több vállalkozóhoz füződő viszonyában anyavállalatnak minősül. Az anyavállalat két beszámolót készít: egy egyedi éves beszámolót és egy összevont beszámolót. Utóbbinak részei a konszolidált mérleg, a konszolidált eredménykimutatás és a konszolidált kiegészítő melléklet. Ugyan nem része, de ezzel összhangban el kell készítenie a konszolidált üzleti jelentést is. Ennek célja, hogy a teljes cégcsoportól, annak vagyonáról, a közös tevekénységröl, annak eredményességéről teljes, átfogó képet kapjunk.

Nem kell konszolidált éves beszámolót készíteni, ha a két egymást követö üzleti évben a mérlegforduló napján a 3 mutatóérték közül bármelyik kettő nem haladja meg a következő határértékeket:

- mérlegfőösszeg a 6000 millió forintot,

- éves nettó árbevétel a 12000 millió forintot,

- az üzleti évben foglalkoztatottak száma a 250 föt.

\subsection{A beszámoló letétbe helyezése és közzététele}

A számviteli törvény hatálya alá tartozó vállalkozónak az elkészült és jóváhagyott éves beszámolót, egyszerüsített éves beszámolót, az adózott eredmény felhasználására vonatkozó határozatot a könyvvizsgálói záradékkal együtt az üzleti év utolsó fordulónapját követő 5. hó utolsó napjáig letétbe kell helyezni a cégbíróságon. (Az összevont éves beszámolót az üzleti év utolsó fordulónapját követő 6 . hó utolsó napjáig, forintról devizára vagy fordítva való áttéréskor az áttéréskor készített beszámolót az üzleti év utolsó fordulónapját követő 5. hó utolsó napjáig kell szintén letétbe helyezni.)

Ezt ma már elektronikus úton kell megküldeni az Elektronikus Cégeljárásban Közremüködő Szolgálat részére az erre kialakított online felületen keresztül. A közzétételhez egy elektronikus ürlapot kell kitölteni, melynek részei: mérleg, eredménykimutatás, kiegészítő melléklet, független könyvvizsgálói jelentés (amennyiben kötelező, vagy a vállalkozás választotta), adózott eredmény felhasználására vonatkozó határozat, de az üzleti jelentést nem. Az elektronikus úton való megküldéssel minden vállalkozás igazából már eleget tesz a letétbehelyezési és közzétételi kötelezettségeinek is, azaz a cégbíróságnak már nem kell külön elküldenie, illetve csak abban az esetben, ha a cégbíróság ezt a végzésben kifejezetten elrendeli.

A letétbe helyezett beszámolók nyilvánosak, azokról bárki kaphat tájékoztatást, másolatot készíthet, az e-cégbíróság weboldalról le is töltheti azokat. A konszolidált beszámolót készítö tőzsdei cégeknek a normál közzétételen kívül honlapjukon is közzé kell tenniük beszámolójukat és üzleti jelentésüket, melynek legalább az utóbbi két év adatait tartalmaznia kell.

Azon külföldi székhelyü vállalkozás magyarországi fióktelepe, melynek székhelye az EU tagállamaiban van, vagy a székhelyez az EU-n kívüli de EU-s szabályok szerint készíti el beszámolóját, mentesül a közzétételi és a könyvvizsgálati kötelezettség alól (de a letétbe helyezés alól nem). 
Amennyiben az állami adóhatóság (NAV) megállapítja, hogy a vállalkozás határidőig nem küldte meg a beszámolót, akkor az elöírt határidőt követő 15 napon belül, 30 napos határidő tüzésével, 500 ezer forintig terjedő mulasztási bírság kiszabása mellett felhívja az adózó figyelmét ennek pótlására. Ennek nem teljesülése esetén újra felhívja a figyelmét, 60 napos határidő kitủzésével, 1 millió forintig terjedő mulasztási bírság kiszabása mellett. Ha ezen idő alatt sem pótolja a vállalkozás a kötelezettségét, úgy az állami adóhatóság az adózó adószámát - felfüggesztés nélkül - hivatalból törli, és kezdeményezi a cég megszüntnek nyilvánítását (kivéve, ha az adózó már úgyis kényszertörlés alatt áll). A cégbíróság a NAV elektronikus értesítésének megérkezését követő 20 munkanapon belül megszüntnek nyilvánítja a céget, illetve felügyeleti illeték megfizetését is elöírják, melynek összege 100 ezer forint.

\subsection{Kiegészítö melléklet}

Mivel bizonyos beszámolórészek (mérleg, eredménykimutatás) nem túl olvasmányosak és tömörítve tartalmaznak információkat, ezért annak, aki meg szeretné érteni a vállalkozásnál zajló gazdasági folyamatokat, aki a falak mögé szeretne nézni, segítségre van szüksége. Ebben tud segíteni két olyan tájékoztató anyag, mely ezeket a plusz információkat megadja.

A kiegészítő melléklet értelme és feladata, hogy kiegészítse, elmagyarázza a mérlegből és az eredménykimutatásból kiolvasható információkat. Ahogy már korábban megbeszéltük, a számvitel célja - többek között - a megbízható, valós összkép bemutatása, így ennek megfelelően értékelni kell a vállalkozás vagyoni, pénzügyi és jövedelmi helyzetét, a fizetőképességét és a likviditását. Ezt, továbbá az értékelési eljárásokat, a mérlegkészítés időpontját, valamint a választott beszámoló fajtáját tartalmazza a kiegészítő melléklet. Szintén be kell mutatni a kiegészítő mellékletben az üzleti év során feltárt jelentős hibákat, és azok hatását az eredményre. Ami még fontos, hogy a mérleghez és eredménykimutatáshoz kapcsolódó kiegészítéseket olyan sorrendben kell bemutatni, ahogy azok abban szerepelnek.

A kiegészítő melléklet formájára (lehet szöveges és számszerü is) vagy felépítésére nincs kötelező előírás, a számviteli törvény csak a kötelező adattartalmat írja elő, de általában öt részből áll:

\section{Kiegészítő melléklet felépítése:}

Általános rész - ami a vállalat egészére vonatozik (pl. számviteli politika meghatározó elemei, annak változásai, a vállalkozás rövid, lényegre törő bemutatása, a befektetési tükör, a vagyoni, pénzügyi és jövedelmezőségi helyzet rövid elemzése, stb.).

Mérleghez kapcsolódó kiegészítések - ezek lehetnek általános vagy tételes szabályon alapuló elöírások is, (pl. mérlegváltozat (A vagy B) megváltoztatása és annak indoka, újonnan megjelenő vagy összevonásra kerülő mérlegsorok bemutatása, képzett céltartalék és annak felhasználása, kötelezettségek esedékes törlesztőrészlete, értékcsökkenési módszerek megváltoztatása, annak indoklása, terven felüli értékcsökkenés bemutatása, értékhelyesbítések, visszavásárolt saját részvények, üzletrészek megszerzésére vonatkozó adatok stb.). 
Eredménykimutatáshoz kapcsolódó kiegészítések - ezek lehetnek általános vagy tételes szabályon alapuló előírások is (pl. ha a vállalkozás megváltoztatja az eljárást: áttér összköltségesről forgalmi költség eljárásra, értékesítés nettó árbevételének részletezése: főbb vevők és tevékenységek, illetve hazai vagy export szerinti bontásban, $\mathrm{K}+\mathrm{F}$ költségek, kapcsolt vállalkozásokkal szemben elszámolt bevételek bemutatása, illetve ha a vállalkozás forgalmi költség eljárással készíti, akkor a költségnemek bemutatása stb.).

Tájékoztató rész - minden olyan információ, ami a megbízható, valós kép kialakításához szükséges, de nem szerepel az előző részekben (pl. vezető tisztségviselők juttatásai, tárgyévben foglalkoztatott munkavállalók átlagos statisztikai létszáma, személyi jellegű ráfordításai, kibocsájtott részvények száma, névértéke, társasági adó módosító tételei, leányvállalatok adatai stb.).

Cash flow kimutatás - a jelenlegi szabályozás alapján a kiegészítő melléklet része.

\section{5. Üzleti jelentés}

Az üzleti jelentés nem része az éves beszámolónak, a cégbíróságnál nem kell letéttbe helyezni, viszont a vállalkozás székhelyén minden érdekelt rendelkezésére kell bocsájtani, sőt azt le is fénymásolhatja. Magyar nyelven készítendő, a vállalkozás képviseletére jogosult személynek kell aláírnia. Azon vállalkozások, melyek az EU szabályok szerint készítik beszámolójukat (IAS, IFRS), a vállalatirányítási gyakorlatukat is be kell, hogy mutassák.

Alapvetően a vállalkozás jövőjére vonatkozó információkat és a jelenlegi üzletmenetet, valamint a kockázatok és bizonytalanságok (pl. korrupció elleni küzdelemmel és a megvesztegetéssel kapcsolatban) kezelését kell bemutatnia.

Elemzö-értékelő kimutatás, részletezettsége nem meghatározott, de megfelelő mélységben kell, hogy tartalmazza a szükséges információkat, de egyben ne sértsen üzleti titkot. Formája, terjedelme változtatható, elvárás, hogy legyen tömör, érthető, szakszerủ és tárgyilagos.

\section{Ajánlott szerkezete:}

- Vállalat tevékenységének bemutatása, értékelése

- Piaci pozíciók, vevőkapcsolatok

- Felhasznált erőforrások értékelése

- Minőség alakulása

- Kapacitások és azok kihasználása

- Beruházási és befektetési tevékenység értékelése

- $\mathrm{K}+\mathrm{F}+\mathrm{I}$

- Információs és érdekeltségi rendszer

- Tulajdonosi kör és ST

- Jelentős kötelezettségek és kockázatok 


\section{Kitér:}

- Üzleti év zárása utáni lényeges eseményekre

- Társaság várható fejlődése

- $\mathrm{K}+\mathrm{F}$

- Saját részvények megszerzése

- Telephelyek bemutatása

- Foglalkoztatáspolitika

- Környezetvédelmi tevékenység, stb.

Azoknak a vállalkozásoknak, melyek tőzsdei cégek, az üzleti jelentésükben - többek között részletesen be kell mutatniuk a jegyzett tőke összetételét és annak megváltozását, a részesedések átruházásának korlátozásait, a jelentős közvetlen és közvetett részesedéssel rendelkező befektetőket, a különleges irányítási jogokat megtestesítő részesedések tulajdonosait és e jogokat, a szavazati jogok korlátozását, az olyan megállapodásokat, mely a szavazati jogok étruházását eredményezheti, stb.

\subsection{Vezetői számvitel}

Nem árt tisztázni, hogy Magyarországon egyféle számvitel müködik, és ez a pénzügyi számvitel (vagy röviden számvitel), azonban ennek van egy ráépülése, kiegészítése, mely segítheti a döntéshozókat és a tulajdonosokat a döntéseik meghozatalában, ezt vezetői számvitelnek hívjuk. Ez a vezetői számvitel olyan információkat állít elő a vezetők részére, melyek segítségével a racionális gazdálkodás megvalósítható, vagyis:

- a rendelkezésre álló erőforrások optimális felhasználása biztosítható,

- a teljesítmények tovább növelhetök,

- a költségek és ráfordítások optimalizálhatók, és

- mindezek eredményeképpen az eredmény növelhetö, maximalizálható.

A vezetői számvitel magyarországi kialakulása viszonylag rövid időtávra tekint vissza, csak a rendszerváltásig kell visszatekintenünk. 1991-ig nem beszélhetünk klasszikus vezetői számvitelről, addig a Pénzügyminisztérium elöírásainak megfelelően szolgáltatta minden gazdálkodó a számviteli információkat a vállalaton kívüli szervek, felhasználók részére egy egységes szabályozás alapján. Majd 1992-től a nemzetközi gyakorlatnak megfelelőn kialakult Magyarországon is a vezetői számvitel, mely alapján a „,belső felhasználók” (menedzsment, tulajdonosok) saját igényeiknek megfelelően alakíthatták ki információs igényeiket, így a magyar számviteli szabályozás ketté vált pénzügyi számvitelre és vezetői számvitelre.

Gyorsan szögezzük le, hogy hiába telt el azóta három évtized, azóta sincs egységes vélemény, hogy mi pontosan a vezetői számvitel tartalma, és melyek a helyesen alkalmazható módszerek. Abban viszont egyetértenek a szakértők, hogy mindenképpen szükség van a jó vállalati müködéshez egy olyan rendszerszemléletre, amely a szervezéstől a tervezésen, elszámolási és értékelési rendszeren túl, egyben egy információszolgáltatási rendszer is. 
Nézzük meg, hogy mi is pontosan ez a két számvitel, mi a különbség közöttük! A pénzügyi számvitel a gazdálkodáshoz szükséges vagyonban bekövetkezett változásokat, valamint a gazdálkodás eredményére hatással lévő eseményeket rögzíti, számolja el, azaz az elszámolás eszköze, ahogy azt már korábban áttekintettük. Tulajdonképpen a törvényes jogszabályi elöírásokhoz igazodó, a vállalat teljes körü bemutatásához szükséges külső információs szükségletet elégíti ki, a számviteli törvény által meghatározott keretein belül. Dokumentálja a rendelkezésre álló, ill. tevékenységhez felhasznált erőforrások mennyiségben és pénzértékben kifejezett mozgását, változását.

Ezzel szemben „A vezetői számvitel a gazdasági egységen belüli felhasználók, a különböző vezetési szintek információs igényét kielégítő, döntéstámogató módszerek és eljárások összessége." (Pucsek, 2013.) Segít az erőforrások optimális felhasználásában, a teljesítmény-növelésben, a költségcsökkentésben, egyben az eredmény maximalizálásban.

Ezek alapján megfogalmazhatjuk, hogy a vezetői számvitel magában foglalja:

- A vezetőség információkkal való ellátása (azaz információ-menedzsmentnek is hívhatjuk).

- Vezetői tanácsadás, mely során értékelhetjük egy vezetői döntésnek a várható hatásait (pl. ha az értékesítési célok nem valósulnak meg, akkor visszafogunk egy korábban jóváhagyott beruházást).

- A döntés, majd végrehajtás után fontos, hogy a végeredményt összehasonlítsák a tervezettel, és ez az ellenőrzés legyen naprakész.

- Fontos a kommunikáció is, minél rövidebb legyen a reagálási idő, és mindig csak annyi információval látjuk el az érdekelteket, amennyire szükségük van. Ennek a kommunikációnak kétoldalúnak kell lennie, csak úgy lesz sikeres.

- Rendszerszemlélet: komplex rendszert kell alkotnia a költségellenörzéssel és a pénzügyi beszámolási rendszerek tervezésével.

- Rugalmasság: a vezetői számvitelnek rugalmasan, gyorsan kell reagálnia a vállalat müködésében bekövetkező mindenféle változásra.

Azért ne felejtsük el, hogy a vezetői számvitelnek korlátai is vannak, mivel az általa előállított információk egy része szubjektív megítélésből származik, illetve nem csodaszer, csak egy segédeszköz, nem a vezetői számviteli osztály vezeti a vállalatot, ez csak eszköz, amely a menedzsment igényeinek kiszolgálására jön létre. 


\begin{tabular}{|c|c|}
\hline Pénzügyi számvitel & Vezetői számvitel \\
\hline \multicolumn{2}{|c|}{ Előállított információk elsődleges címzettjei } \\
\hline A piac szereplői. & Menedzsment, tulajdonosok. \\
\hline \multicolumn{2}{|c|}{ Az információ előállítás szabályozása } \\
\hline $\begin{array}{l}\text { Számviteli törvény által (alapelvek, tar- } \\
\text { talom). }\end{array}$ & $\begin{array}{l}\text { Vállalkozó szabályozza, nagy szabadságfok- } \\
\text { kal, rugalmasan. }\end{array}$ \\
\hline \multicolumn{2}{|l|}{ Célkitüzés } \\
\hline $\begin{array}{l}\text { Beszámolási kötelezettség teljesítése, } \\
\text { információ szolgáltatása befektetési, } \\
\text { hitelezés döntésekhez. }\end{array}$ & $\begin{array}{l}\text { Vezetői döntéstámogatás a tevékenység ter- } \\
\text { vezéséhez, ellenőrzéséhez, a teljesítmények } \\
\text { méréséhez. }\end{array}$ \\
\hline \multicolumn{2}{|l|}{ Előállított információk jellege } \\
\hline Értékbeni adatok $(\mathrm{Ft})$. & Értékbeni és mennyiségi (kevert) adatok. \\
\hline \multicolumn{2}{|l|}{ Az információ időorientáltsága } \\
\hline $\begin{array}{l}\text { Múltbeli gazdasági eseményekre fóku- } \\
\text { szál (lásd pl. beszámoló, könyvelés). }\end{array}$ & $\begin{array}{l}\text { Múltbeli és terv (jövőbeli) adatok, melyekkel } \\
\text { a jelenre és a jövőre állít elő (tervez) informá- } \\
\text { ciókat. }\end{array}$ \\
\hline \multicolumn{2}{|l|}{ Információk terjedelme } \\
\hline $\begin{array}{l}\text { A beszámoló a vállalkozás egészét mu- } \\
\text { tatja be. }\end{array}$ & $\begin{array}{l}\text { Kisebb egységekre (szervezeti egységek, ter- } \\
\text { mékek), az értékteremtésre fókuszál. }\end{array}$ \\
\hline \multicolumn{2}{|l|}{ Az információ ellenőrzése } \\
\hline $\begin{array}{l}\text { A számviteli törvényben meghatározott } \\
\text { körben kötelező a könyvvizsgálat }{ }^{1} \text {. }\end{array}$ & $\begin{array}{l}\text { A külső auditálás nem kötelező, a belső ellen- } \\
\text { őrzés vizsgálja az adatok valódiságát. }\end{array}$ \\
\hline \multicolumn{2}{|l|}{ Az információ megbízhatósága } \\
\hline $\begin{array}{l}\text { A számviteli törvény alapján elöállított } \\
\text { adatok megbízhatóak és valósak. }\end{array}$ & $\begin{array}{l}\text { Az infók a meghatározott követelményeknek } \\
\text { megfelelően ésszerüek és relevánsak. }\end{array}$ \\
\hline \multicolumn{2}{|l|}{ A nyújjtott információ pontossága } \\
\hline $\begin{array}{l}\text { Alapvető követelmény a pontosság és } \\
\text { ellenőrzöttség. }\end{array}$ & $\begin{array}{l}\text { Itt is a viszonylagos pontosság a követel- } \\
\text { mény. }\end{array}$ \\
\hline \multicolumn{2}{|c|}{ Az információ előállításának módszere } \\
\hline $\begin{array}{l}\text { A számvitel által alkalmazott, ismert } \\
\text { módszerek, a kettős könyvvitel rend- } \\
\text { szerében. }\end{array}$ & $\begin{array}{l}\text { A követelményeknek megfelelően kiválasz- } \\
\text { tott módszer, analitikákat használ. }\end{array}$ \\
\hline \multicolumn{2}{|l|}{ Reakciója } \\
\hline Megismer, tudomásul vesz. & Változtatni kíván, intézkedéseket indukál. \\
\hline
\end{tabular}

Forrás: saját szerkesztés Kardos és mtsai (2016) alapján

\footnotetext{
${ }^{1}$ Nem kötelező a könyvvizsgálat, ha az üzleti évet megelőző két üzleti év átlagában a vállalkozás éves nettó árbevétele nem haladta meg a 300 millió forintot, és az üzleti évet megelőző két üzleti év átlagában a vállalkozó által átlagosan foglalkoztatottak száma nem haladta meg az 50 föt. A felmentést azonban a törvényben meghatározott szervezetek nem alkalmazhatják, például azok a kettős könyvvitelt vezetö vállalkozók, ahol a könyvvizsgálatot jogszabály írja elö, a takarékszövetkezetek, a konszolidálásba bevont vállalkozások és a külföldi székhelyü vállalkozások magyarországi fióktelepe, kivéve azon külföldi székhelyű vállalkozások magyarországi fióktelepét, amely vállalkozás székhelye az Európai Unió valamely tagállamában található. A felmentést nem alkalmazhatják azon vállalkozások, melyek kivételes eset miatt, a megbízható és valós kép bemutatása érdekében eltérnek a számviteli törvény elöírásaitól, a közérdeklődésre számot tartó gazdálkodók (például a tőzsde) és az a vállalkozó, akinek a tárgyévi üzleti év mérlegfordulónapján 10 millió forintot meghaladó, 60 napnál régebben lejárt köztartozása van.
} 


\subsection{Költséggazdálkodás}

Ahhoz, hogy egy cég a vállalkozási tevékenységét megkezdje, illetve folytassa, természetesen erőforrásokra van szüksége, például munkaerőre, eszközökre, gépekre, készletekre, stb. Ezeknek az erőforrásoknak az árát a költség definíciójával fejezzük ki.

Költség: a termék előállításához, szolgáltatásnyújtáshoz felhasznált erőforrások pénzben kifejezett értéke.

Fontos, hogy ne keverjük össze a költséget a kiadással és a ráfordítással. A kiadás üzemgazdaságilag nem más, mint eszközcsökkenés, pénzügyi fogalomként pedig pénzeszköz-csökkenés (cash out-flow, lásd később). Azt tudjuk, hogy minden költség kiadással jár együtt (kivéve az értékcsökkenési leírást), de nem minden kiadás költség, elég, ha például a hiteltörlesztésre gondolunk (az pénzügyi kiadás, de nem költség).

A ráfordítás ennél szélesebb körü fogalom, mivel magában foglal olyan eszközfelhasználást is, amelyek nem jelennek meg költségként, mégis befolyásolják az eredményt. Ilyen például az időszaki értékesítés bekerülési költsége, ahol a költség az értékesítéssel együtt válik ráfordítássá, vagy a pénzügyi műveletek ráfordításai, az igazgatási, általános és egyéb költségek (azaz az értékesítéstől független költségek).

Ezek után röviden tekintsünk át pár olyan témakört, melyekkel találkozni fogunk az elemzések során!

\section{Költséggazdálkodás}

A költséggazdálkodás olyan tevékenység, amelynek középpontjában a költség áll, és tartalmazza annak tervezését, utalványozását (engedélyezését, lásd még később), analitikus nyilvántartását, főkönyvi elszámolását, kalkulációját, ellenőrzését (lásd még később), elemzését, és információrendszerének kialakítását. Ez a költséggazdálkodás nem más, mint eszközgazdálkodás, mivel az erőforrás felhasználásig még lehet dönteni arról, hogy az eszközből költség legyen-e, vagy sem, azaz felhasználjuk-e most, vagy még ne. Ebben az esetben is az alapszabály: a vállalkozási tevékenység megköveteli a rendelkezésre álló erőforrások hatékony felhasználását. A felhasználni kívánt erőforrásoknak ismerni kell a nagyságát, összetételét és a hasznosítási lehetőségeit, majd a sokféle megoldás közül azt a legkedvezőbbet kell kiválasztani, ami a legnagyobb profitot eredményezi.

\section{Költségutalványozás}

Ejtsünk pár szót a költség utalványozásról, azaz a költség engedélyezésről, mivel fontos téma a költségekkel kapcsolatban. Ez nem más, mint egy jogosultság, amikor a vezetö engedélyezi az erőforrás felhasználását, vagy éppen utasítást ad erre. Ahhoz, hogy ezt tisztázzuk, meg kell határozni, hogy ki jogosult erre (ez lehet személy vagy szervezet), mi alapján történik az utalványozás (normák, keretszámok), mikor történik az utalványozás, (lehet utólagos és formális is), illetve az utalványozási és bizonylati rendet. Azt is mondhatjuk, hogy ez egyben folyamatba épített ellenőrzés is, ami a költségek ellenőrzésére vonatkozik. 


\section{Költségek ellenőrzése}

A költséggazdálkodást időnként ellenőrizni is kell, ez kiterjed a költséggazdálkodás valamenynyi területére, az lesz a kérdés, hogy megfelelő, azaz reális terveket készítettek-e? Fontos, hogy a költségellenőrzés ne csak az asztalfiók számára készüljön, mert kötelező, hanem, hogy valóban használható legyen a költségek befolyásolására, azaz lássuk belöle, hogy melyik költség mikor és miért tért el a tervezettől. Szintén lényeges, hogy ennek pontosnak, naprakésznek kell lennie, nem évekkel később készítjük el, hiszen akkor már nem tudjuk a tapasztalatokat felhasználni a költségek befolyásolására. Pár jellemző kérdés ezzel kapcsolatban:

- A költségek elszámolása megfelelő? Betartják-e a bizonylati elvet, fegyelmet?

- Készült költségkalkuláció, ha igen, az valóban használható?

- Ki végzi a költségek ellenőrzését, milyen gyakorisággal, milyen módszerekkel, milyen területen, stb.

\subsection{Az ellenőrzés}

Mivel a gazdasági és pénzügyi elemzés több ponton is összekapcsolódik az ellenőrzéssel, röviden ismertetjük az alapvető ellenőrzési ismereteket is. Nem célunk a részletes bemutatás, mivel az ellenőrzés témakörében elkészült egy másik jegyzet, melyben minden részletesen elolvasható és megismerhetö.

Nézzük, mi is az ellenőrzés. Ellenőrzés alatt általában valamely cél vagy feladat lehető leghatékonyabb megvalósítása érdekében végzett ténymegállapító, valamilyen követelményhez viszonyító tevékenységet értünk. Ehhez kapcsolódik az is, hogy az elvégzett tevékenységet értékelik, és javaslatokat is tesznek, ha az eltér a kívánatostól, azaz állásfoglalásokkal és megállapításokkal segíti a menedzsment munkáját. A célja az, hogy ha hibát talál, azt jelezze, és olyan intézkedéseket javasoljon, hogy az a jövőben ne ismétlődjön meg. A konkrét célt mindig az az általa képviselt érdekek határozzák meg (lásd majd később: tulajdonosi és hatósági ellenőrzés).

Az ellenőrzés a vezetés egyik fontos funkciója, annak nélkülözhetetlen eleme, mely a hibák, eltérések jelzésével tulajdonképpen bemutatja a vezetői döntések végrehajtásának helyességét, segít a vizsgált tevékenység értékelésében, a hibák keletkezésének megelőzésében. Hiba esetén megvizsgálja és megállapítja a felelősséget, de itt nem áll meg, hanem elősegíti a javaslatok kialakításával azon intézkedések meghozatalát, amelyek a hibák felszámolását célozzák. 


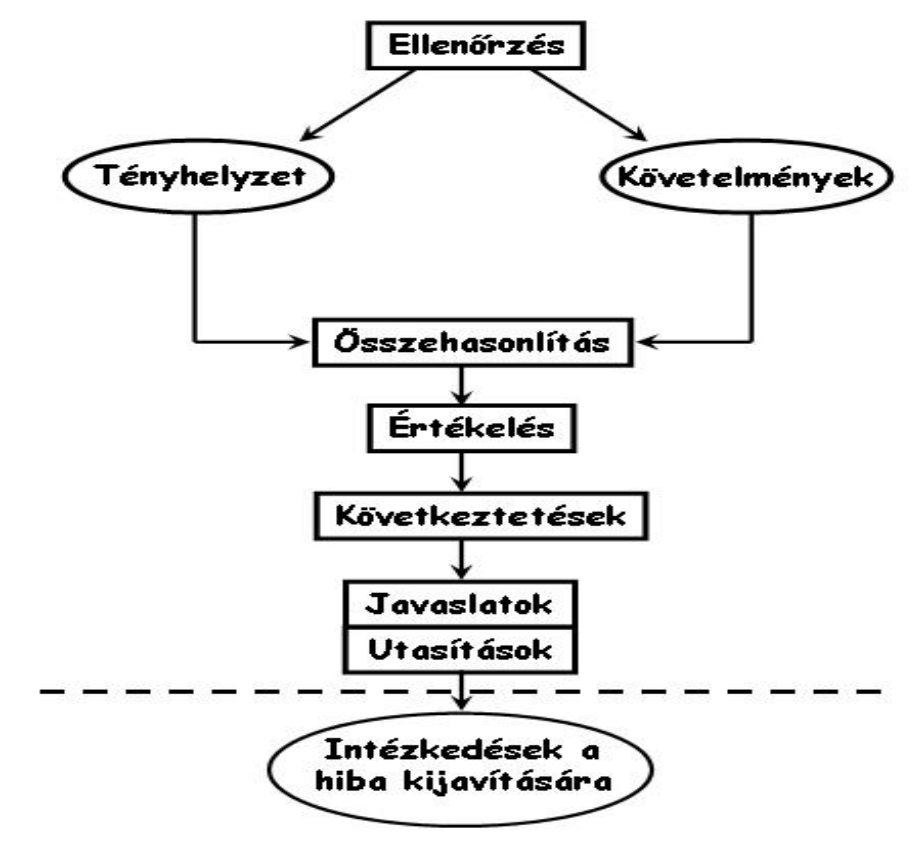

\section{1. ábra Az ellenörzési tevékenység általános modellje}

Forrás: Ficzeréné Nagymihály, 2009.

Ahogy már említettük, az ellenőrzés célját mindig az határozza meg, hogy minek, kinek az érdekéből végzik az ellenőrzési tevékenységet. Ez alapján végezhető:

- tulajdonosi érdekből, amikor egy vállalkozásnál az elvégzett tevékenység hatékonyságára, gazdaságosságára irányul az ellenőrzés, illetve

- hatósági, illetve közérdekből végzett ellenőrzés, amikor a törvények, jogszabályok, rendeletek elöírásainak betartására irányul a törvényességi ellenőrzés.

Az ellenőrzés tárgya mindig valamilyen emberi tevékenység, vagy magatartás, továbbá egy embercsoport (vállalkozás) össztevékenységének az értékelése és annak hiteles rögzítése.

Az ellenőrzésnek két alapvető módszerét ismerjük, hogy melyiket kell alkalmazni, azt mindig az ellenőrzés célja és tárgya határozza meg. Ez lehet:

- direkt (azaz jelen idejü), például rovancsolás, szemle, közös jegyzőkönyv, illetve

- indirekt: például dokumentumok felülvizsgálata, egyeztetés.

Az ellenőrzés rendszere az adott ország vagy gazdasági egység tulajdonviszonyaitól függ, lehet:

- az Európai Unió ellenőrzési rendszere,

- az ország/állam ellenőrzési rendszere,

- egy vállalkozás belső ellenőrzési rendszere,

- egy költségvetési szerv belső ellenőrzési rendszere. 
Az ellenőrzés jellemzői az ún. ellenőrzési alapelvekben jutnak kifejezésre, vegyük sorra ezeket.

- Teljesség: teljesen lefedi a nemzetgazdaság, ország egészét, ellátja valamennyi érdek képviseletét és védelmét.

- Rendszeresség és tervszerüség: az ellenőrzési tevékenységeket az ellenőrzési munkatervben rögzített rendben és rendszeresen ismétlődően végzik.

- Folytonosság, illetve hézagmentesség: az ellenőrzési időszakok kihagyás nélkül követik egymást, az előző ellenőrzés óta eltelt időszakra terjed ki, nem maradhat ki akárcsak egy nap sem.

- Törvényesség: az ellenőröknek és az ellenőrzötteknek is be kell tartaniuk a kötelezettségeiket meghatározó jogszabályi elöírásokat, egyben megilletik őket különböző jogok.

- Ésszerüség: az ellenőrzés tárgyának és témájának helyes megválasztását, a megfelelő munkamegosztás igényét jelenti, figyelembe kell venni a költség-haszon szemléletet.

- Megalapozottság: az ellenőrzési megállapításoknak megdönthetetlennek és objektívnek kell lenniük.

- Függetlenség: az ellenőrök az általuk képviselt tulajdonosi vagy hatósági érdek érvényesítésében mindenféle befolyástól mentesen járnak el, azaz mindentől és mindenkitől függetlenül végzik munkájukat.

- Hatékonyság: az ellenőrzésnek eredményesnek (gazdaságosnak) kell lennie.

- Kockázat-orientáltság: az ellenőrzési munkában elkerülhető a tévedés, ha a megfelelő kockázati mérlegeléseket elvégzik, például azon tevékenységeket ellenőrizzük gyakran és alaposan, amelyeknél nagyobb eséllyel fordulhat elő hiba, tévesztés.

Végezetül pedig röviden tekintsük át az ellenőrzések csoportosítását, azaz fajtáit.

\section{Idöpontja szerint lehet:}

- előzetes, mely felméri a végrehajtás várható hatását, eredményét, vagy megakadályozza valamilyen esemény bekövetkezését (pl. beruházás előkészítése),

- egyidejü, ennek célja feltárni a végrehajtásban tapasztalható akadályokat, eltéréseket, hogy megfelelö időben intézkedni lehessen (pl. munkafolyamatba épített ellenörzések, számla kiállításának ellenőrzése), továbbá

- utólagos, melyet a tevékenység után végeznek el, amikor egy munkafolyamat már véget ért (pl. bizonylati elv, fegyelem, utalványozási elöírások betartásának ellenőrzése).

\section{Követelményrendszer szerint:}

- szabályszerüségi, mely vizsgálja, hogy az adott tevékenység megfelelően szabályozott-e, a szabályozás érvényre jut-e (pl. belső szabályzat, pénzkezelés ellenőrzése),

- teljesítmény ellenőrzés, mely vonatkozhat a gazdaságosságra (adott, megfelelő színvonalon a költségek minimalizálása), a hatékonyságra (eredmény és felhasznált források kapcsolata) és az eredményességre (tervezett és tényleges eredmény viszonya, célok megvalósításának mértéke). 
Tartalmi szempontból lehet pénzügyi vagy szakmai ellenőrzés.

- Pénzügyi ellenőrzés, mely megvizsgálja, hogy például egy beszámoló mennyire megbízható, de ide soroljuk a pénzintézeti ellenőrzést, az uniós támogatások felhasználásának ellenőrzését, az Állami Számvevőszék pénzügyi ellenőrzését, a független könyvvizsgálói ellenőrzést és a belső ellenőrzést is. Ide sorolhatók még a gazdasági hatékonyságára, a munkaerő, a pénzeszközök ésszerü, megfelelö felhasználásának vizsgálatára irányuló ellenőrzések is.

- Szakmai ellenőrzés, mely naturális követelményt kér számon, például szabvány, minőség, egészségügyi vagy tűzvédelmi elöírások betartásának ellenőrzését.

Ellenörzés nagyságrendje szerint:

- átfogó, azaz komplex elemzés, a legfontosabb feladatok egymással összefüggő vizsgálatát, elemzését és értékelése jelenti (pl. gazdaságossági mutatók vizsgálata az egész vállalkozásra vonatkozóan),

- téma, amikor egy időben, több helyen végzik az ellenőrzés, általánosítható következtetések levonására (pl. tárgyi eszközökkel kapcsolatban minden ellenőrzünk: állapota, nyilvántartása, kihasználtsága, stb.),

- cél, mely egy-egy körülhatárolt eseti kérdésre, feladatra, vagy részterületre irányul (pl. tárgyi eszközök kihasználtsága).

\section{Megbízó szerint lehet}

- belső ellenőrzés, amikor az ellenőr az ellenőrzött szerezettel áll munka, vagy megbízásos viszonyban, és az ellenőrzést a vizsgált szerv megbízásából és részére végzi, illetve

- külső ellenőrzés, amikor valamely külső szerv megbízásából és részére végzik azt, azaz az ellenőr az ellenőrzött szervezettől független (pl. NAV ellenőrzés).

\section{Részletesség szerint lehet:}

- tételes (teljes körü), amikor a feladattal kapcsolatos minden esemény, tárgy, müvelet vizsgálandó (pl. az összes októberi kimenő számla ellenőrzése),

- mintavételes, valamilyen elv alapján választott részsokaság tételes vizsgálata (pl. minden hétfőn kiállított számla vizsgálata),

- próbaszerü, amikor a sokaság egy-egy elemét „szúrópróbaszerüen” vizsgáljuk.

\section{Forrásjegyzék}

1) Bíró, T., Kresalek, P., Pucsek, J. Sztanó, I., Pucsek, J. (Szerk.) (2016). Vállalkozások tevékenységének komplex elemzése. Budapest: Perfekt Gazdasági Tanácsadó Oktató és Kiadó Zrt.

2) Blumné Bán, E., Kresalek, P., Pucsek, J. (2011). A vállalati elemzés alapismeretei. Budapest: Saldo Pénzügyi Tanácsadó és Informatikai Zrt.

3) Borbély, K., Pataki, L., Polyák, I. (2013). A számviteli politika és a vezetői számvitel összefüggései. CONTROLLER INFO, (1)7, 22-26. 
4) Böcskei, E., Bács, Z., Fenyves, V., Tarnóczi, T. (2015). Kockázati tényezők lehetséges előrejelzése, a gazdálkodás felelősségének kérdése a számviteli beszámolóból nyerhető adatok tükrében. CONTROLLER INFO, 2015(3), 7-14.

5) Ficzeréné Nagymihály, K. (2009). Vállalkozások ellenőrzése. Gyöngyös: Károly Róbert Főiskola

6) Igazságügyi Minisztérium. (2019). Online Beszámoló és ürlapkitöltő Rendszer. Letöltés dátuma: 2019. 06. 12. forrás: https://e-beszamolo.im.gov.hu/ebekuldes letöltve: 2019. január 16.

7) Kardos, B., Sisa, K. A., Szekeres, B., Veress, A. (2016). Vezetöi számvitel (elmélet, módszertan). Budapest: Saldo Pénzügyi Tanácsadó és Informatikai Zrt.

8) Kardos, B., Lukács, L. I., Miklósyné Ács, K., Siklósi, Á., Simon, Sz., Sisa, K. A., Szekeres, B., Veres, A., Zatykó, Zs, Marozsák, Á. (Szerkesztő) (2018). Pénzügyi számvitel. Budapest: Perfekt Gazdasági Tanácsadó Oktató és Kiadó Zrt.

9) Koloszár, L. (2013). Vállalati információs rendszerek. Sopron: Nyugat-magyarországi Egyetem Kiadó

10) Kresalek, P., Merétey Vida, Zs. (2008). Ellenőrzési alapismeretek. Budapest: Perfekt Gazdasági Tanácsadó Oktató és Kiadó Zrt.

11) Magyar Könyvvizsgálói Kamara. (2019). A számviteli törvény 2016. évi változásai az évközi módosítás tükrében. Letöltés dátuma: 2019. 06. 12. forrás: https://mkvkok.hu/aszamviteli-torveny-2016-evi-valtozasai-az-evkozi-modositas-tukreben-1-resz

12) Nádasdi, F. (Szerk.) (2011, 2015). Gazdasági elemzés és értékelemzés. Sopron: Gazdasági Tudásközpont Alapítvány

13) Parádi-Dolgos, A., Polyák, I., Varga, J. (Szerk.). (2013). A magyar számvitel rendszere. Sopron: A Soproni Felsőoktatásért Alapítvány

14) Polyák, I.Varga, J., Madaras, A., Szóka, K. (2006). A számvitel alapjai. Miskolc: Vasas-Pesti Kft.

15) Pucsek, J. (2013). Pénzügyi és számviteli kontrolling. Letöltés dátuma: 2019. 02. 20. forrás: https://www.tankonyvtar.hu/hu/tartalom/tamop412A/0007_e7_penzugyi_es_szamviteli_kontrolling_scorm/vezetoi_szamvitel_kontrolling_JI82Hqck6MFgfUDE.html

16) Róth, J., Adorján, Cs., Lukács, J., Veit, J. (2018). Pénzügyi számvitel. Budapest: Magyar Könyvvizsgálói Kamara Oktatási Központ Kft.

17) Szóka, K. (2012). A pénzügyi-számviteli tervezés és a controlling összefüggései és gyakorlata: Különös tekintettel a kis- és középvállalkozásokra. Sopron: Nyugat-magyarországi Egyetem Kiadó

18) Wolters Kluver. (2000-2019). 2000. évi C. törvény a számvitelről. Letöltés dátuma: 2019. 06. 12. forrás: https://net.jogtar.hu/jogszabaly?docid=a0000100.tv 


\section{A vagyoni helyzet elemzése}

A mérleg átfogó elemzése során első lépésben a vagyoni és pénzügyi helyzet elemzésére kerítenek leggyakrabban sort, melyből a vagyoni helyzet elemzését taglaló módszerek, mutatók kerülnek e fejezetben bemutatásra. Az ezt követő fejezetben a pénzügyi helyzetet elemző módszerek és mutatók is ismertetésre kerülnek. Az átfogó elemzésen túl szokásos az egyes mérlegtételek részletes vizsgálatát is elvégezni, továbbá lehetséges a tényadatokat korábbi évek bázisadataihoz vagy előzetesen kitüzött tervértékekhez is viszonyítani.

Az átfogó elemzéssel kapcsolatban elmondható, hogy kétirányú elemzési módszer használatos: a vertikális és a horizontális elemzés.

A vertikális elemzés során a mérleg adatai közül csak egy oldal adatait (azaz vagy csak az eszköz vagy csak a forrás oldal adatait) elemezzük úgy, hogy az adott oldal összetételét vizsgáljuk különböző felbontásban (pl. eszköz főcsoportok, eszközcsoportok vagy egyes eszközoldali mérlegtételek aránya, ill. ugyanígy a forrás oldali megfelelők) megoszlási viszonyszámokkal. Ezek jellemzően kijelölik a vizsgálatok további lehetséges irányait és rámutatnak a kritikus csoportokra, tételekre.

A horizontális elemzés során - szemben a vertikális elemzéssel - a mérleg mindkét oldaláról adatokat vonunk be az elemzésbe, tulajdonképpen a két oldal mérlegsor, ill. mérlegtétel adatainak összevetésére kerül sor.

Ezeken felül a mérleg egyes részeinek változásait szokás abszolút mértékű változásokkal, elmozdulásokkal is jellemezni, vagy azokat százalékos mértékben kifejezni a tervadatokhoz vagy bázisadatokhoz képest. Sőt megbízható és azonos tartalmú adatok birtokában más vállalkozásokkal vagy ágazati referencia-értékekkel is összevethetők a vállalkozás adatai.

\subsection{Az eszközök és források belső arányainak vizsgálata}

Amikor a vagyonnak csak egy-egy elemét akarjuk vizsgálni, ill. annak részarányát egy nagyobb egységhez képest, akkor az ún. struktúramutatókat (statisztikai megnevezésük szerint megoszlási viszonyszámokat) használunk. Jelentéstartalmukat tekintve a rész és egész viszonyát mutatják be százalékos formában kifejezve.

$$
\text { struktúramutató }=\frac{\text { részadat }}{\text { összesített adat }} \times 100
$$

Az elemzési szempontoktól függően viszonyítási (összesített) adatként használható a mérlegföösszeg (mérlegföcsoport vagy mérlegcsoport vizsgálata esetén) vagy a mérlegfőcsoportok és mérlegcsoportok is (azok belső összetételének elemzése során).

Szokásos még az ún. intenzitási viszonyszámokat is használni, melyek esetében valamely tényező részarányát határozzuk meg legalább két vagy több, a vizsgált tényezőt is tartalmazó összesített adathoz képest (pl. tőkeáttételi mutatók). Kifejezése szintén százalékos formában szokásos. 


$$
\begin{aligned}
& \text { intenzitási mutató } 1=\frac{1 . \text { tétel }}{1 . \text { tétel }+2 \cdot \text { tétel }} \times 100 \\
& \text { intenzitási mutató } 2=\frac{2 \cdot \text { tétel }}{1 . \text { tétel }+2 \cdot \text { tétel }} \times 100
\end{aligned}
$$

Az eszköz oldali csoportok és tételek vizsgálatára használt mutatókat eszközszerkezeti, a forrás oldali csoportok és tételek vizsgálatára használt mutatókat forrásszerkezeti mutatóknak nevezzük.

\subsubsection{A leggyakrabban használt, eszközszerkezetet jellemző módszerek, mutatók}

A vállalkozás eszközei (tárgyiasult - materiális, nem tárgyiasult - immateriális, pénzügyi), a müködéséhez, a vállalati cél eléréséhez szükséges elemek. Ezek összetétele vállalkozásonként eltérö, alapvetően függ a vállalkozás tevékenységi körétől. Egy termelö, ipari vállalat esetében a tárgyi eszközök, gépek képviselhetnek nagy részarányt, egy kereskedő vállalkozásnál a készletek, egy kutató cégnél pedig az immateriális javak többek között. Az optimális részarányra általános szabály nem fogalmazható meg, sokkal inkább az iparági sztenderdek jelenthetnek támpontot a kérdésben.

Az eszközök besorolása azok rendeltetésének időtartama alapján történik meg, mely besorolást a vállalat maga végzi el. Az egy évnél hosszabb ideig használt eszközöket befektetett eszközöknek, a rövidebb ideig használtakat forgóeszközöknek nevezzük.

Az eszközállomány változásának időbeli alakulását jellemezhetjük az egyes időszakokban aktuális adatokkal, az azok közötti eltérések abszolút és százalékos értékével, valamely bázisként kiválasztott időszak bázisértékeihez képest történő abszolút és százalékos eltérésekkel, ill. a változás átlagos mértékével és annak százalékos formájával.

Az éven belüli összehasonlítások esetében az immateriális javak, tárgyi eszközök és a befektetett eszközök esetében adott gazdálkodási év első (január 1.) és utolsó (december 31.) napjának adatait érdemes összevetni a gazdálkodás eredményességének mérése céljából. (Itt kell megjegyezni, hogy nem minden vállalkozásnál azonos az üzleti év a naptári évvel). Ugyanakkor a készletek vagy a követelések esetében a vállalkozás jellegéből adódóan különféle szezonális hatások figyelhetők meg jelentős ingadozásokkal, ezért ezeknél sok esetben célszerübb a gazdálkodási év adott időszakának értékét a megelőző gazdálkodási év azonos időszakával összevetni vagy ezek átlagos értékeit összehasonlítani (pl. kronologikus átlaggal).

A mérleg eszköz oldalán jellemzően a befektetett eszközök és a forgóeszközök részarányát szokás számolni, az aktív időbeli elhatárolások esetében ez nem tipikus (4.1. táblázat). 
4.1. táblázat Az eszköz-föcsoportok arányait számszerüsítö mutatók

\begin{tabular}{|l|l|}
\hline Mutató képlete & \multicolumn{1}{|c|}{ Mutató jelentése } \\
\hline$\frac{\text { Befektetett eszközök }}{\text { Eszközök összesen }} \times 100$ & $\begin{array}{l}\text { Befektetett eszközök aránya a teljes va- } \\
\text { gyonban. }\end{array}$ \\
\hline$\frac{\text { Forgóeszközök }}{\text { Eszközök összesen }} \times 100$ & $\begin{array}{l}\text { Forgóeszközök aránya a teljes vagyon- } \\
\text { ban. }\end{array}$ \\
\hline
\end{tabular}

A befektetett eszközök arányának növekedése pozitívnak minősíthető, ha olyan beruházások valósultak meg, amelyeket a jövőbeni termelés mennyiségi vagy minőségi javítása indokolt. Egyúttal ennek növekedése arra is felhívja a figyelmet, hogy a termelés állandó költségeivel a jövőben fokozottabb mértékben kell számolni.

A forgóeszközök arányának növekedése akkor értékelhető pozitívan, ha az olyan eszközök beszerzéséből adódik, amellyel javul a vállalkozás rugalmassága és alkalmazkodó képessége a termelésben és a külső környezeti igények tekintetében.

A forgóeszközöket szokás a tárgyi eszközökkel összevetve intenzitási mutatókkal is vizsgálni, hiszen ez az a két eszköz csoport, amelyek egymáshoz viszonyított aránya a vállalkozás jellege által leginkább meghatározott (4.2. táblázat).

\section{2. táblázat A tárgyi eszközök és forgóeszközök intenzitásmutatói}

\begin{tabular}{|c|c|}
\hline Mutató képlete & Mutató jelentése \\
\hline$\frac{\text { Tárgyi eszközök }}{\text { Tárgyi eszközök }+ \text { Forgóeszközök }} \times 100$ & $\begin{array}{l}\text { Tárgyi eszközök aránya a tárgyi eszkö- } \\
\text { zök és forgóeszközök összegén belül. }\end{array}$ \\
\hline$\frac{\text { Forgóeszközök }}{\text { Tárgyi eszközök }+ \text { Forgóeszközök }} \times 100$ & $\begin{array}{l}\text { Forgóeszközök aránya a tárgyi eszkö- } \\
\text { zök és forgóeszközök összegén belül. }\end{array}$ \\
\hline
\end{tabular}

Az egyes eszközcsoportok értéke hasonlóan a föcsoportokhoz, viszonyítható a mérlegfööszszeghez (4.3. táblázat). Ezek értékei ugyancsak attól függhetnek, hogy milyen jellegủ tevékenységet folytat egy vállalat.

\section{3. táblázat Eszközcsoportok részarányai az összes eszközértékhez képest}

\begin{tabular}{|l|l|}
\hline Mutató képlete & \multicolumn{1}{c|}{ Mutató jelentése } \\
\hline$\frac{\text { Tárgyi eszközök }}{\text { Eszközök összesen }} \times 100$ & $\begin{array}{l}\text { Tárgyi eszközök aránya az összes va- } \\
\text { gyonon belül }\end{array}$ \\
\hline$\frac{\text { Készletek }}{\text { Eszközök összesen }} \times 100$ & $\begin{array}{l}\text { Készletek aránya az összes vagyonon } \\
\text { belül }\end{array}$ \\
\hline$\frac{\text { Követelések }}{\text { Eszközök összesen }} \times 100$ & $\begin{array}{l}\text { Követelések aránya az összes vagyonon } \\
\text { belül }\end{array}$ \\
\hline
\end{tabular}


A befektetett eszközök föcsoport eszközfajtáinak struktúramutatói mindhárom eszközcsoportra használatosak (4.4. táblázat). Itt olyan eszközök kerülnek számbavételre, melyek egy éven túl szolgálják a vállalkozást a vállalati cél megvalósításában.

\section{4. táblázat A befektetett eszközök csoportjainak részarányait számszerüsítö mutatók}

\begin{tabular}{|l|l|}
\hline \multicolumn{1}{|c|}{ Mutató képlete } & \multicolumn{1}{c|}{ Mutató jelentése } \\
\hline$\frac{\text { Immateriális javak }}{\text { Befektetett eszközök összesen }} \times 100$ & $\begin{array}{l}\text { Immateriális javak aránya a befektetett } \\
\text { eszközökön belül. }\end{array}$ \\
\hline$\frac{\text { Tárgyi eszközök }}{\text { Befektetett eszközök összesen }} \times 100$ & $\begin{array}{l}\text { Tárgyi eszközök aránya a befektetett } \\
\text { eszközökön belül. }\end{array}$ \\
\hline$\frac{\text { Befektetett pénzügyi eszközök }}{\text { Befektetett eszközök összesen }} \times 100$ & $\begin{array}{l}\text { Befektetett pénzügyi eszközök aránya a } \\
\text { befektetett eszközökön belül. }\end{array}$ \\
\hline
\end{tabular}

Az egyes eszközcsoportokon belül szokásos bizonyos mérlegtételek arányainak külön-külön történő vizsgálata. A legtipikusabbakat foglalja össze a 4.5. táblázat. Az immateriális javak közé a vállalkozás rendelkezésére álló nem anyagi természetü, a termelést szolgáló javak (pl. szabadalmak, szellemi termékek stb.), jogok, később megtérülő kiadások tartozna. A tárgyi eszközök közé az üzemben tartott és hosszabb időtáv alatt használt anyagi eszközöket (pl. infrastruktúra, gépek, berendezések, tenyészállatok stb.), a befektetett pénzügyi eszközök közé pedig a tartós jövedelemszerzési céllal (pl. osztalék vagy árfolyamnyereség) ill. irányítási, befolyási jog megszerzése céljából befektetett eszközöket soroljuk.

4.5. táblázat A legtipikusabb befektetett eszköz mérlegtételek részarányait számszerüsítö mutatók

\begin{tabular}{|c|c|}
\hline Mutató képlete & Mutató jelentése \\
\hline \multicolumn{2}{|c|}{ Immateriális javak csoportja } \\
\hline$\frac{\text { Alapítás }- \text { átszervezés aktivált értéke }}{\text { Immateriális javak összesen }} \times 100$ & $\begin{array}{l}\text { A vállalkozás alapításával vagy át- } \\
\text { szervezésével kapcsolatban felme- } \\
\text { rült közvetlen költségek aránya az } \\
\text { immateriális javakon belül. }\end{array}$ \\
\hline$\frac{\text { Kísérleti fejlesztés aktivált értéke }}{\text { Immateriális javak összesen }} \times 100$ & $\begin{array}{l}\text { A vállalkozás által történt fejleszté- } \\
\text { sek eredményeként a jövőben meg- } \\
\text { térülő költségek aránya az immate- } \\
\text { riális javakon belül. }\end{array}$ \\
\hline$\frac{\text { Vagyoni értékű jogok }}{\text { Immateriális javak összesen }} \times 100$ & $\begin{array}{l}\text { Az ingatlanhoz, szellemi termék- } \\
\text { hez nem kapcsolódó jogok aránya } \\
\text { az immateriális javak között. }\end{array}$ \\
\hline
\end{tabular}




\begin{tabular}{|c|c|}
\hline$\frac{\text { Üzleti vagy cégérték }}{\text { Immateriális javak összesen }} \times 100$ & $\begin{array}{l}\text { Cégfelvásárláshoz kapcsolódó kifi- } \\
\text { zetések aránya az immateriális ja- } \\
\text { vakon belül. }\end{array}$ \\
\hline$\frac{\text { Szellemi termékek }}{\text { Immateriális javak összesen }} \times 100$ & $\begin{array}{l}\text { A termelésben hasznosítható, nem } \\
\text { anyagi javak aránya az immateriá- } \\
\text { lis javakon belül. }\end{array}$ \\
\hline \multicolumn{2}{|c|}{ Tárgyi eszközök csoportja } \\
\hline$\frac{\text { Ingatlanok }}{\text { Tárgyi eszközök összesen }} \times 100$ & $\begin{array}{l}\text { Földterületek és az ahhoz tartósan } \\
\text { kapcsolódó anyagi javak aránya a } \\
\text { tárgyi eszközökön belül. }\end{array}$ \\
\hline$\frac{\text { Beruházások }}{\text { Tárgyi eszközök összesen }} \times 100$ & $\begin{array}{l}\text { Termelési célból beszerzett, elöál- } \\
\text { lított, de még üzembe nem helye- } \\
\text { zett tárgyi eszközök aránya a tárgyi } \\
\text { eszközökön belül. }\end{array}$ \\
\hline$\frac{\text { Műszaki berendezések, gépek, járművek }}{\text { Tárgyi eszközök összesen }} \times 100$ & $\begin{array}{l}\text { Termelési célból már üzembe he- } \\
\text { lyezett tárgyi eszközök aránya a } \\
\text { tárgyi eszközökön belül. }\end{array}$ \\
\hline$\frac{\text { Egyéb berendezések, felszerelések, járművek }}{\text { Tárgyi eszközök összesen }} \times 100$ & $\begin{array}{l}\text { A műszaki berendezések, gépek, } \\
\text { járművek közé nem tartozó, } \\
\text { üzembe helyezett tárgyi eszközök } \\
\text { aránya a tárgyi eszközökön belül. }\end{array}$ \\
\hline $\begin{array}{l}\text { (Műszaki berendezések, gépek, járművek }+ \\
\frac{\text { Egyéb berendezések, felszerelések, járművek) }}{\text { Tárgyi eszközök összesen }} \times 100\end{array}$ & $\begin{array}{l}\text { Minden, termelési célból már } \\
\text { üzembe helyezett tárgyi eszköz } \\
\text { aránya a tárgyi eszközökön belül. }\end{array}$ \\
\hline \multicolumn{2}{|c|}{ Befektetett pénzügyi eszközök csoportja } \\
\hline$\frac{\text { Részesedések }}{\text { Befektetett pénzügyi eszközök összesen }} \times 100$ & $\begin{array}{l}\text { Más vállalatban részesedést meg- } \\
\text { testesítő értékpapírok aránya a be- } \\
\text { fektetett pénzügyi eszközök között. }\end{array}$ \\
\hline$\frac{\text { Értékpapírok }}{\text { Befektetett pénzügyi eszközök összesen }} \times 100$ & $\begin{array}{l}\text { Részesedést nem megtestesítő ér- } \\
\text { tékpapírok aránya a befektetett } \\
\text { pénzügyi eszközök között. }\end{array}$ \\
\hline$\frac{\text { Adott kölcsönök }}{\text { Befektetett pénzügyi eszközök összesen }} \times 100$ & $\begin{array}{l}\text { A következő évben nem lejáró, hi- } \\
\text { telviszonyt megtestesítő értékpapí- } \\
\text { rok aránya a befektetett pénzügyi } \\
\text { eszközök között. }\end{array}$ \\
\hline
\end{tabular}

Az immateriális javak esetében hasznos lehet annak elemzése, hogy mekkora az apport, a vásárolt és a saját előállítású immateriális javak aránya.

A tárgyi eszközök esetében szokás ún. hányadmutatókat is számolni, melyek bizonyos eszközcsoportok arányát számszerüsítik az aktivált tárgyi eszközökön belül (4.6. táblázat). 


\begin{tabular}{|c|l|}
\hline Mutató képlete & \multicolumn{1}{|c|}{ Mutató jelentése } \\
\hline$\frac{\text { Gépek }}{\text { Aktivált tárgyi eszközök összesen }} \times 100$ & Gépesítettség foka \\
\hline$\frac{\text { Járművek }}{\text { Aktivált tárgyi eszközök összesen }} \times 100$ & Jármüellátottság mértéke \\
\hline$\frac{\text { Ingatlanok }}{\text { Aktivált tárgyi eszközök összesen }} \times 100$ & Ingatlanellátottság mértéke \\
\hline
\end{tabular}

A hányadmutatókat jellemzően azonos ágazatban tevékenykedő más cégek értékeihez érdemes viszonyítani, hiszen a vállalkozás ipari, kereskedelmi stb. jellege alapvetően meghatározza mértéküket. Az ipari vállalkozások esetében a gépek és berendezések azok, melyek jellemzően nagy részarányt képviselnek, a szállítmányozó cégek esetében a jármüvek lehetnek ilyenek. Mindezzel párhuzamosan érdemes ezek elhasználódottsági fokát is figyelemmel követni, hogy teljes képet kaphassunk.

További elemzési szempont lehet a tárgyi eszközök összetételének vizsgálatakor a rendeltetési cél szerinti elemzés (pl. üzemi célokat, igazgatási célokat stb. szolgáló eszközök), továbbá az eredet szerinti vizsgálatok (pl. apportból származó vagy vásárolt eszközök).

A befektetett eszközök vizsgálata történhet még a fenti mutatókon túl aszerint, hogy azok milyen társasági formátum szerint történtek befektetésre vagy mekkora hányadot tesznek ki a kapcsolt vállalkozásban.

\subsubsection{A forgóeszközök fócsoportját elemzö mutatók}

A forgóeszközök főcsoport eszközfajtáinak struktúramutatói mindegyik eszközcsoportra használatosak (4.7. táblázat). Itt olyan eszközök kerülnek számbavételre, melyek egy éven belül szolgálják a vállalkozást a vállalati cél megvalósításában.

4.7. táblázat A forgóeszközök csoportjainak részarányait számszerüsítö mutatók

\begin{tabular}{|l|l|}
\hline Mutató képlete & \multicolumn{1}{c|}{ Mutató jelentése } \\
\hline Készletek & $\begin{array}{l}\text { Készletek aránya a forgóeszközökön } \\
\text { belül }\end{array}$ \\
\hline$\frac{\text { Forgóeszközök összesen }}{\text { Követelések }} \times 100$ & $\begin{array}{l}\text { Követelések aránya a forgóeszközökön } \\
\text { belül }\end{array}$ \\
\hline$\frac{\text { Forgóeszközök összesen }}{\text { Értékpapírok }} \times 100$ & $\begin{array}{l}\text { Értékpapírok aránya a forgóeszközökön } \\
\text { belül }\end{array}$ \\
\hline Forgóeszközök összesen & $\begin{array}{l}\text { Pénzeszközök aránya a forgóeszközö- } \\
\text { kön belül }\end{array}$ \\
\hline$\frac{\text { Pénzeszközök }}{\text { Forgóeszközök összesen }} \times 100$ &
\end{tabular}


A forgóeszközök eszközcsoportjainak megoszlási viszonyszámai átfogó képet adnak arról, hogy a folyamatos, fennakadástól mentes müködéshez megfelelő összetételü forgóeszközökkel rendelkezik-e a vállalkozás (4.8. táblázat). A pénzeszközök közé tartozó elemek azok, amelyek leginkább mobilizálhatók és az azonnali pénzszükséglet fedezetéül szolgálhatnak. Szintén viszonylag gyorsan pénzzé tehetők a készletek és a követelések egyes csoportjai (pl. árukészlet, késztermékek), de vannak, amelyek sokkal kevésbé (pl. félkész termékek).

A fenti mutatókat célszerü átlagadatok alapján vizsgálni, kiküszöbölendő az ezen eszközök állományában nagymértékü és gyakran bekövetkező ingadozásokat.

4.8. táblázat A legtipikusabb forgóeszköz mérlegtételek részarányait számszerüsitő mutatók

\begin{tabular}{|c|c|}
\hline Mutató képlete & Mutató jelentése \\
\hline \multicolumn{2}{|l|}{$\begin{array}{ll}\text { Készletek csoportja } \\
\end{array}$} \\
\hline$\frac{\text { Anyagok }}{\text { Készletek összesen }} \times 100$ & $\begin{array}{l}\text { A termelés során eredeti formájukat } \\
\text { elveszítő alapanyagok aránya a } \\
\text { készleteken belül. }\end{array}$ \\
\hline$\frac{\text { Befejezetlen termelés és félkész termékek }}{\text { Készletek összesen }} \times 100$ & $\begin{array}{l}\text { A megmunkálás alatt lévő vagy } \\
\text { már egy bizonyos termelés részfo- } \\
\text { lyamaton átesett termékek aránya a } \\
\text { készleteken belül. }\end{array}$ \\
\hline$\frac{\text { Állatok }}{\text { Készletek összesen }} \times 100$ & $\begin{array}{l}\text { A termelés során tartott állatok ará- } \\
\text { nya a készleteken belül. }\end{array}$ \\
\hline$\frac{\text { Késztermékek }}{\text { Készletek összesen }} \times 100$ & $\begin{array}{l}\text { Az összes termelési részfolyamaton } \\
\text { átesett késztermékek aránya a kész- } \\
\text { leteken belül. }\end{array}$ \\
\hline$\frac{\text { Áruk }}{\text { Készletek összesen }} \times 100$ & $\begin{array}{l}\text { Továbbértékesítésre beszerzett } \\
\text { készletek aránya a készleteken be- } \\
\text { lül. }\end{array}$ \\
\hline$\frac{\text { Készletekre adott előlegek }}{\text { Készletek összesen }} \times 100$ & $\begin{array}{l}\text { A pénzügyileg már teljesített, kész- } \\
\text { letekre fizetett előlegek aránya a } \\
\text { készleteken belül. }\end{array}$ \\
\hline$\frac{\text { Saját termelésű készletek }}{\text { Készletek összesen }} \times 100$ & $\begin{array}{l}\text { A befejezetlen-, félkész- és készter- } \\
\text { mékek, ill. állatok aránya a készle- } \\
\text { teken belül. }\end{array}$ \\
\hline$\frac{\text { Vásárolt készletek }_{A}}{\text { Készletek összesen }} \times 100$ & $\begin{array}{l}\text { Az anyagok és az áruk aránya a } \\
\text { készleteken belül. }\end{array}$ \\
\hline$\frac{\text { Vásárolt készletek }_{B}}{\text { Készletek összesen }} \times 100$ & $\begin{array}{l}\text { Az anyagok, az áruk és a készletre } \\
\text { adott előlegek aránya a készleteken } \\
\text { belül. }\end{array}$ \\
\hline
\end{tabular}




\begin{tabular}{|c|c|}
\hline \multicolumn{2}{|c|}{ Követelések csoportja } \\
\hline$\frac{\text { Vevők }}{\text { Követelések összesen }} \times 100$ & $\begin{array}{l}\text { A nem kapcsolt vagy egyéb része- } \\
\text { sedési viszonyban lévő vállalat irá- } \\
\text { nyába fennálló, teljesítésböl adódó } \\
\text { követelések aránya a követelések } \\
\text { között. }\end{array}$ \\
\hline $\begin{array}{c}\text { Követelések kapcsolt és tulajdoni részesedéssel } \\
\text { rendelkező vállalkozással szemben } \\
\begin{array}{c}\text { Követelések összesen } \\
\times 100\end{array}\end{array}$ & $\begin{array}{l}\text { A kapcsolt vagy egyéb részesedési } \\
\text { viszonyban lévő vállalat irányába } \\
\text { fennálló, teljesítésből adódó köve- } \\
\text { telések aránya a követelések között. }\end{array}$ \\
\hline$\frac{\text { Váltókövetelések }}{\text { Követelések összesen }} \times 100$ & $\begin{array}{l}\text { Vevői követeléssel szemben elfoga- } \\
\text { dott, későbbi időpontban esedékes } \\
\text { fizetési igények (váltókövetelések) } \\
\text { aránya a követelések között. }\end{array}$ \\
\hline \multicolumn{2}{|c|}{ Értékpapírok csoportja } \\
\hline$\frac{\text { Eladásra vásárolt kötvények }}{\text { Értékpapírok összesen }} \times 100$ & $\begin{array}{l}\text { A vásárlást követő évben lejáró, } \\
\text { forgatási célból megvásárolt, hitel- } \\
\text { viszonyt megtestesítő kötvények } \\
\text { aránya az értékpapírok között. }\end{array}$ \\
\hline 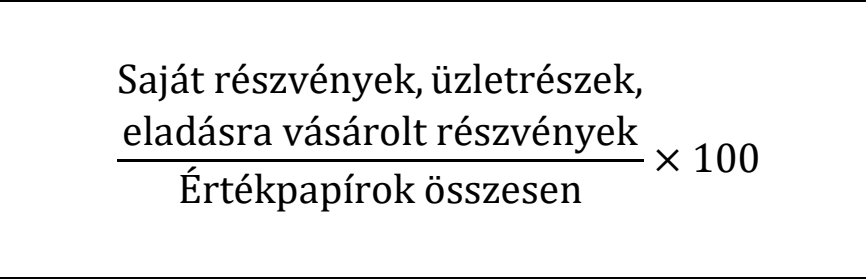 & $\begin{array}{l}\text { A visszavásárolt saját részvények } \\
\text { és üzletrészek, ill. a forgatási célból } \\
\text { megvásárolt, tulajdonjogot megtes- } \\
\text { tesítő részvények aránya az érték- } \\
\text { papírok között. }\end{array}$ \\
\hline$\frac{\text { Egyéb értékpapírok }}{\text { Értékpapírok összesen }} \times 100$ & $\begin{array}{l}\text { Pl. közraktárjegyek, pénztárjegyek, } \\
\text { letéti jegyek aránya az értékpapírok } \\
\text { között. }\end{array}$ \\
\hline \multicolumn{2}{|c|}{ Pénzeszközök csoportja } \\
\hline$\frac{\text { Pénztár }}{\text { Pénzeszközök összesen }} \times 100$ & $\begin{array}{l}\text { A vállalkozás pénztárában lévő } \\
\text { készpénz aránya a pénzeszközök } \\
\text { között. }\end{array}$ \\
\hline$\frac{\text { Csekkek }}{\text { Pénzeszközök összesen }} \times 100$ & $\begin{array}{l}\text { A pénzhelyettesítő funkciót ellátó } \\
\text { csekkek aránya a pénzeszközök kö- } \\
\text { zött. }\end{array}$ \\
\hline$\frac{\text { Bankbetétek }}{\text { Pénzeszközök összesen }} \times 100$ & $\begin{array}{l}\text { A vállalkozás betéti számláján lévő } \\
\text { pénz aránya a pénzeszközök között. }\end{array}$ \\
\hline
\end{tabular}

A készletek összetételének változása felhívhatja a figyelmet a vállalkozásnál végbemenő kedvező vagy kedvezőtlen irányú változásokra, melyek alaposabb vizsgálata ekkor indokolt lehet. Akkor megfelelő a készletállomány nagysága, ha az képes biztosítani a folyamatos és zavartalan termelési és értékesítési folyamatot, azaz nem szükséges alapanyag vagy félkész termék hiánya miatt a termelésnek indokolatlanul állnia, azaz a vevőket sikerül kiszolgálni megfelelő 
időn belül. A készletösszetétel jellegzetes az egyes nemzetgazdasági ágazatokban. A kereskedelemben a vásárolt készletek nagyobb aránya a jellemző, az iparban a saját termelésủ készleteké. A vásárolt készletek aránya mutatónak két változata is használatos.

A követelések állománya a vállalkozás részéről már teljesített és elfogadott megrendelések ellenértékeként jogszerüen elvárható fizetési igények. Jellemzően döntő többségét a vevőkövetelések (áruszállításból és szolgáltatásnyújtásból adódóan) teszik ki. Fontos, hogy a követelések állománya ne haladja meg azt a szintet, amelyet a vállalkozás már nem tud finanszírozni (tulajdonképpen hitelezni) ill. ne legyenek közte olyan tételek jelentős mértékben, amelyek lejártak és behajthatóságok kétséges vagy lehetetlen.

Az értékpapírok csoportjában a forgatási célból, nem tartós befektetés céljából megvásárolt értékpapírokat soroljuk (hitel- és részesedési jogviszonyt megtestesítőket egyaránt).

A pénzeszközök közé a vállalkozás likviditását biztosító eszközök tartoznak, amelyek a kötelezettségek relatíve gyors teljesítését teszik lehetővé, forintban és devizában egyaránt nyilvántarthatók.

\subsubsection{A leggyakrabban használt forrásszerkezetet jellemző módszerek, mutatók}

A vállalkozás forrásai a vállalkozás eszközeinek finanszírozásául szolgálnak, egyúttal megmutatják annak forrását is. A forrásokat két nagy csoportba, a saját források (saját tőke) és az idegen források (kötelezettségek) csoportjába soroljuk. Mind a saját tőke, mind a kötelezettségek szolgálhatnak a vállalkozás befektetett eszközeinek és forgóeszközeinek fedezetéül, hitelt ugyanakkor a tulajdonosok is nyújthatnak. A saját vagyont a tulajdonosok, a külső forrásokat pedig befektetők és hitelezők bocsátják a vállalkozás rendelkezésére. A mérleg forrás oldalán ezeken felül még két főcsoportot, a céltartalékokat és a passzív időbeli elhatárolásokat találjuk. Előbbit a vállalkozás eredményéből képezik a jövőben várható kötelezettségekre (pl. a vállalkozásban végrehajtandó átszervezési költségekre), utóbbi korrekciós tételeket tartalmaz, amelyek az adott évi eredményt csökkentik (pl. előre megkapott, de egyébként csak a következő tárgyévben esedékes bevételek).

A forrásállomány változásának időbeli alakulását - hasonlóan az eszközállományhoz - jellemezhetjük az egyes időszakokban aktuális adatokkal, az azok közötti eltérések abszolút és százalékos értékével, valamely bázisként kiválasztott időszak értékeihez képest történő abszolút és százalékos eltérésekkel, ill. a változás átlagos mértékével és annak százalékos formájával. A saját tőke csoportjára nem jellemző, hogy év közben ingadozásokat mutatna, ezért ennek esetében nem szükséges az átlagadatok használata.

A mérleg forrás oldalán három főcsoport - saját tőke, céltartalékok, kötelezettségek - részarányát szokás számolni, a passzív időbeli elhatárolások esetében ez nem tipikus. (4.9. táblázat) 
4.9. táblázat A forrás-föcsoportok arányait számszerüsítö mutatók

\begin{tabular}{|c|l|}
\hline Mutató képlete & \multicolumn{1}{|c|}{ Mutató jelentése } \\
\hline$\frac{\text { Saját tőke }}{\text { Források összesen }} \times 100$ & $\begin{array}{l}\text { Tőkeellátottság, } \\
\text { saját tőke aránya teljes tőkén belül. }\end{array}$ \\
\hline$\frac{\text { Céltartalékok }}{\text { Források összesen }} \times 100$ & $\begin{array}{l}\text { Céltartalékok aránya a teljes tőkén be- } \\
\text { lül. }\end{array}$ \\
\hline$\frac{\text { Kötelezettségek }}{\text { Források összesen }} \times 100$ & $\begin{array}{l}\text { Kötelezettségek aránya a teljes tőkén } \\
\text { belül. }\end{array}$ \\
\hline
\end{tabular}

A tőkeellátottság mutatóját alapvetően meghatározza a vállalkozás tevékenységi köre. Minél magasabb ennek az értéke, ill. időbeli összehasonlítás során a mutató növekedése kedvező tendenciát jelenít meg. A forrásösszetétel minősége egyúttal meghatározza a vállalat életképességét, hitelképességét, ill. idegen tőke vonzó képességét is. Annál pozitívabbnak ítélhetjük meg egy vállalkozás finanszírozási helyzetét, minél nagyobb a saját tőke aránya, ugyanis ez azt jelenti, hogy a vállalkozás müködésének forrásául a vállalkozás saját tulajdonában lévő források szolgálnak, nincsen kiszolgáltatva külső hitelezőknek, befektetőknek. Ez egyúttal azt is jelenti, hogy szükség esetén az ilyen vállalkozás új hitelező bevonásakor is előnyöket élvez, az ilyen vállalkozásokba szívesebben fektetnek be új, külső szereplők. A saját és idegen források aránya nemzetgazdasági áganként eltérő lehet, ill. a vállalkozás jellege is meghatározza, hogy milyen arányokkal optimális müködni. Általánosan elfogadható irányelv, hogy a saját tőke aránya a teljes forrásszerkezetben nem jó, ha 1/3 alá csökken (Zéman - Béhm, 2016).

A céltartalékok aránya a vállalkozás gazdálkodásában rejlő kockázatokat jellemzik, hiszen a céltartalék a jövőben felmerülő, váratlan kötelezettségekre nyújt fedezetet, ezzel stabilizálva a működés finanszírozhatóságát.

A kötelezettségek időbeli növekedése bár látszólag kedvezőtlen, de nem feltétlenül kell így értékelni, hiszen egy vállalkozás üzletmenetének bővülése és növekedése esetén ez szinte elkerülhetetlen. Mindenképpen fontos az elemzések során is szem elött tartani azonban, hogy a növekvő kötelezettségek egyúttal növekvő finanszírozási terhet (kamatteher) is jelentenek majd a jövőben, amelyre a vállalkozásnak fel kell készülnie, továbbá a vállalkozás egyre nagyobb mértékü függőséget fog mutatni a külső finanszírozókkal szemben. Az sem mindegy ugyanakkor, hogy a rövid-, vagy a hosszú lejáratú kötelezettségek vannak-e túlsúlyban,

Szintén fontos szempont a tőkeszerkezet értékelésekor, hogy a vállalkozás eszközei és azok finanszírozási forrásai legyenek összhangban. Jellemzően azt tekinthetjük optimálisnak, ha a vállalkozás tartós befektetéseit, beruházásait, hosszú távon használt eszközeit tartós források (pl. saját tőke, hosszú lejáratú hitelek) biztosítják (4.10. táblázat), míg a rövidtávon használatos eszközöket, forgóeszközöket a rövid távú hitelek és idegen források adják. (Utóbbi esetében az sem baj, ha egy részének fedezetéül a saját tőke tud szolgálni, mint hosszú távon rendelkezésre álló forrás.) 
4.10. táblázat A befektetett eszközök fedezettségének mutatói

\begin{tabular}{|c|c|}
\hline Mutató képlete & $\begin{array}{c}\text { Mutató jelen- } \\
\text { tése }\end{array}$ \\
\hline$\frac{\text { Saját tőke }}{\text { Befektetett eszközök összesen }} \times 100$ & $\begin{array}{l}\text { Befektetett esz- } \\
\text { közök fedezete } \\
\text { „A” }\end{array}$ \\
\hline$\frac{\text { Saját tőke }+ \text { Hosszú lejáratú kötelezettségek }}{\text { Befektetett eszközök összesen }} \times 100$ & $\begin{array}{l}\text { Befektetett esz- } \\
\text { közök fedezete } \\
\text { „B” }\end{array}$ \\
\hline$\frac{\text { Saját tőke }+ \text { Hátrasorolt kötelezettségek }}{\text { Befektetett eszközök összesen }} \times 100$ & $\begin{array}{l}\text { Befektetett esz- } \\
\text { közök fedezete } \\
\text { „C” }\end{array}$ \\
\hline$\frac{\text { Saját tőke }+ \text { Hátrasorolt és hosszú lejáratú kötelezettségek }}{\text { Befektetett eszközök összesen }} \times 100$ & $\begin{array}{l}\text { Befektetett esz- } \\
\text { közök fedezete } \\
\text { „D” }\end{array}$ \\
\hline$\frac{\text { Saját tőke }+ \text { Hosszú lejáratú kötelezettségek }}{\text { Befektetett eszközök }+ \text { Tartósan lekötött forgóeszközök összesen }} \times 100$ & $\begin{array}{l}\text { Befektetett esz- } \\
\text { közök fedezete } \\
\text { „E” }\end{array}$ \\
\hline
\end{tabular}

A befektetett eszközök „A” fedezeti mutatójánál a minimálisan elvárt érték 1 (esetleg 0,8), hiszen fontos, hogy hosszú távon használt forrásokból történjen a befektetett eszközök fedezése. A „B” mutató az „A” mutatóhoz képest „engedékenyebb” mutató, hiszen a hosszú lejáratú kötelezettségeket is bevonja a fedezeti elemek közé. Ennek használata akkor elfogadható, ha a hosszú lejáratú kötelezettségek nem egyszeri tételként, hanem rendszeresen jelen vannak a vállalkozás finanszírozási szerkezetében. Ilyenkor a „B” mutató esetében is 1 az elvárt érték. Fontos mindemellett, hogy mindkét mutató időbeli alakulását is figyelemmel kell követni. Mivel a befektetett eszközökön felül a forgóeszközöknek is lehet olyan állománya, amely tartósan van lekötve, ezért a „B” mutató pontosítható az „E” mutató mintájára. A „C” mutató a saját tőkét kiegészíti azon idegen tőke elemmel, amely esetleges csőd esetében az összes idegen tőke elem közül a legkedvezőtlenebb helyzetben van, azaz amelynek hitelezője minden más hitelező kielégítését követően kerül kifizetésre. Ilyen szempontból kizárólag a tulajdonosoknál van kedvezőbb helyzetben az ilyen hitelező, így az ő általa rendelkezésre bocsátott forrásokat is nyugodtan kezelhetjük a vállalkozás saját tulajdonában lévő tőkeelemekkel egyenrangúan. Ezt fejezi ki a „C” mutató, amely így ennek a két tőkeelemnek a fedezeti mértékét hivatott bemutatni a befektetett eszközökre vonatkoztatva. A „D” mutató tulajdonképpen a „C” és „B” mutatók további összevonásával még pontosabb képet ad a fedezeti szintről. A fent bemutatott mutatók mindegyike használatos a gyakorlatban.

A vállalkozás alapításakor szükségszerü, hogy rendelkezzen saját tőkével, melyet a tulajdonosok bocsátanak rendelkezésére. A müködés során az esetek túlnyomó többségében idegen tőke bevonására is sor kerül, ez a tőkeáttétel folyamata, azaz amikor a finanszírozási szerkezet megváltozik és az idegen források is megjelennek. A tőkeáttétel mértékét a tőkeáttételi mutatókkal szemléltetjük - jellemzően időszakok összehasonlításával (4.11. táblázat). 


\begin{tabular}{|c|l|}
\hline \multicolumn{1}{|c|}{ Mutató képlete } & \multicolumn{1}{c|}{ Mutató jelentése } \\
\hline$\frac{\text { Idegen tőke }}{\text { Források összesen }} \times 100$ & $\begin{array}{l}\text { Eladósodottsági mutató, } \\
\text { az idegen tőke aránya az összes forrá- } \\
\text { son belül. }\end{array}$ \\
\hline$\frac{\text { Idegen tőke }}{\text { Saját tőke összesen }} \times 100$ & $\begin{array}{l}\text { Tökefeszültségi mutató, } \\
\text { az idegen tőke aránya a saját tőkéhez } \\
\text { képest. }\end{array}$ \\
\hline$\frac{\text { Saját tőke }+ \text { Tartós idegen tőke }}{\text { Források összesen }} \times 100$ & $\begin{array}{l}\text { Tartós források aránya az összes forrás } \\
\text { között. }\end{array}$ \\
\hline$\frac{\text { Adózás előtti eredmény (EBIT) }}{\text { Kamatköltség összesen }}$ & $\begin{array}{l}\text { Kamatfedezeti mutató, } \\
\text { az idegen tőke árának (a kamatnak) a } \\
\text { fedezetéül szolgáló adózás előtti vállal- } \\
\text { kozási eredmény. }\end{array}$ \\
\hline
\end{tabular}

Az eladósodottsági mutató amellett, hogy megmutatja a forrásokon belül az idegen források arányát, egyúttal a vállalkozás eszközeinek fedezetéül szolgáló idegen források arányát is jelenti - hiszen az eszközök és források végösszege a mérlegben meg kell, hogy egyezzen. Ha értéke 30\% körül van, akkor kedvezőnek tekinthető, maximálisan elfogadható mértéke 50\%. A tőkefeszültségi mutató azt szemlélteti, hogy a saját tőkéhez képest több vagy kevesebb-e az idegen tőke aránya. Annál jobb az értéke, minél alacsonyabb. Ha 1 alatti, akkor a vállalkozás forrásszerkezetében a saját tőke elemei meghaladják az idegen tőke elemeit. Ha az előbbiekben megfogalmazott általános irányelvet tekintjük - azaz a saját tőke aránya a teljes finanszírozáson belül nem célszerü, ha 1/3 alá csökken - akkor ez a mutató addig optimális, míg el nem éri a 2-es értéket, mert ezt követően az eladósodottság foka már igen magas.

A tartós források arányát azért szokás elemezni, mert ez ad választ arra, hogy milyen mértékben állnak a vállalkozás rendelkezésére olyan források, amelyekkel hosszú távon számolhat (hiszen a tulajdonosok a saját tőkét is hosszú távra bocsátották rendelkezésre).

A kamatfedezeti mutató azt hivatott bemutatni, hogy a vállalkozás képes-e idegen forrásai kamatainak fedezetére az adózás és kamatfizetés előtti eredményéből. Ha a mutató eredménye 1nél nagyobb, akkor igen, ellenkező esetben nem.

\subsubsection{A saját töke fócsoportját elemzö mutatók}

A saját tőke főcsoporton belüli csoportok és mérlegtételek jelentik tulajdonképpen a vállalkozás saját tulajdonában lévő forrásait, melyeket a tulajdonosok végső soron jellemzően a vállalkozás teljes élettartamára rendelkezésre bocsátanak. Jellemzően hat struktúramutatót szokás számolni ebben a föcsoportban (4.12. táblázat). 
4.12. táblázat A saját töke föcsoportjának részarányait számszerüsítő mutatók

\begin{tabular}{|c|l|}
\hline \multicolumn{1}{|c|}{ Mutató képlete } & \multicolumn{1}{c|}{ Mutató jelentése } \\
\hline$\frac{\text { Jegyzett tőke }}{\text { Saját tőke összesen }} \times 100$ & Jegyzett tőke aránya a saját tőkén belül. \\
\hline$\frac{\text { Saját tőke }}{\text { Jegyzett tőke összesen }} \times 100$ & Saját tőke növekedése. \\
\hline$\frac{\text { Tőketartalék }}{\text { Saját tőke összesen }} \times 100$ & Tőketartalék aránya a saját tőkén belül. \\
\hline$\frac{\text { Jegyzett tőke }+ \text { Tőketartalék }}{\text { Saját tőke összesen }} \times 100$ & $\begin{array}{l}\text { Jegyzett tőke és a tőketartalék összegé- } \\
\text { nek aránya a saját tőkén belül. }\end{array}$ \\
\hline$\frac{\text { Jegyzett, de még be nem fizetett tőke }}{\text { Saját tőke összesen }} \times 100$ & $\begin{array}{l}\text { Jegyzett, de még be nem fizetett tőke } \\
\text { aránya a saját tőkén belül. }\end{array}$ \\
\hline$\frac{\text { Eredménytartalék }}{\text { Saját tőke összesen }} \times 100$ & $\begin{array}{l}\text { Eredménytartalék aránya a saját tőkén } \\
\text { belül. }\end{array}$ \\
\hline
\end{tabular}

A jegyzett tőkét a tulajdonosok alapításkor bocsátják a vállalkozás rendelkezésére, változása tőkeemelés vagy tőkecsökkentés hatására következhet be. (Reciprokmutatója a saját tőke növekedését mérö mutató, mely ideális esetben nagyobb, mint 100\%, azaz ebben az esetben tökenövekedés történik. Alapvetően ez akkor tekinthető pozitívnak, ha saját eredményből történik - pozitív adózott eredményből és eredménytartalékból).

A tőketartalék szintén a tulajdonosok által rendelkezésre bocsátott összeg, amelyet azonban nem jegyeznek be jegyzett tökévé (pl. részvénykibocsátáskor a kibocsátási névérték felett befizetett összeg, vagy a tulajdonosok által véglegesen adott egyéb összeg vagy kapott támogatások, melyek nem visszafizetendők), aránya akkor csökkenhet, ha például jegyzett tőkévé alakítják. Mivel a kettő csoport egyaránt a tulajdonosok részéről véglegesen a vállalkozás részére rendelkezésre bocsátott összegeket tartalmazza, ezért szokás ezeket együttesen is vizsgálni.

A jegyzett, de még be nem fizetett tőke aránya azt jelzi, hogy mekkora az az összeg, amelyet a vállalkozás egyelőre nem tud használni, de a jövőben várható ennek befizetése.

Az eredménytartalék a müködés megelőző éveinek adózott, fel nem használt eredménye, amely az osztalékfizetés alapját is képezi vagy épp a jegyzett tőke növelhető vele. (Csak pozitív eredménytartalék esetén számolható aránya.)

Ehhez kapcsolódóan érdemes összefoglalni az osztalékfizetés szabályait:

- Meg kell határozni az osztalékfizetés forrását az alábbi két eset szerint:

○ negatív tárgyévi adózott eredmény esetén az eredménytartalékot a negatív eredménnyel csökkenteni kell, majd ez képezi az osztalékfizetés lehetséges alapját;

○ pozitív tárgyévi adózott eredmény, de negatív eredménytartalék esetén az osztalék alapjául a negatív eredménytartalékkal csökkentett tárgyévi nyereség szolgálhat. 
- Ezt követően a korrigált saját tőkét kell kiszámítani (Saját tőke - lekötött tartalék pozitív értékelési tartalék) és összevetni az osztalékfizetés forrásával. A kettő közül a kisebb fogja jelenteni az osztalékfizetési korlátot.

\subsubsection{A céltartalékok föcsoportját elemzö mutatók}

Céltartalékot a vállalkozás a tevékenységéből adódó, jövőbeni fizetési kötelezettségekre képez, amelyek a mérleg fordulójának napján majd fenn fognak állni, de egyelöre bizonytalan mértékben és időpontban lesznek esedékesek. Elemzése jellemzően az egyes jogcímek szerint történik, értelemszerüen negatív nem lehet.

\subsection{3. táblázat A céltartalékokat elemzö mutatók}

\begin{tabular}{|c|l|}
\hline \multicolumn{1}{|c|}{ Mutató képlete } & \multicolumn{1}{c|}{ Mutató jelentése } \\
\hline$\frac{\text { Céltartalék a várható kötelezettségekre }}{\text { Céltartalékok összesen }} \times 100$ & $\begin{array}{l}\text { A múltbeli vagy zajló tevékenységek- } \\
\text { böl adódó jövőben keletkezendö kötele- } \\
\text { zettségek tartalékainak aránya a céltar- } \\
\text { talékokon belül. }\end{array}$ \\
\hline$\frac{\text { Céltartalék a jövőbeni költségekre }}{\text { Céltartalékok összesen }} \times 100$ & $\begin{array}{l}\text { A jövöbeni költségek (pl. átszervezés, } \\
\text { környezetvédelmi kiadások) tartalékai- } \\
\text { nak aránya a céltartalékon belül. }\end{array}$ \\
\hline$\frac{\text { Egyéb céltartalék }}{\text { Céltartalékok összesen }} \times 100$ & $\begin{array}{l}\text { Egyéb tartalékok aránya a céltartaléko- } \\
\text { kon belül. }\end{array}$ \\
\hline
\end{tabular}

A céltartalékok összességében jellemzően alacsony mértékủek a forrásokon belül.

\subsubsection{A kötelezettségek föcsoportját elemző mutatók}

A vállalkozás kötelezettségei tulajdonképpen az idegen forrásokat (tartozások, kapott előlegek más vállalkozók felé, tartozások a hitelezők felé stb.) foglalják magukban. Lejárat és esedékesség szerint három csoportba soroljuk őket:

- hátrasorolt kötelezettségek (azon hitelezők forrásai, akik egy esetleges adósságrendezés során csak a tulajdonosokat elözik meg a törlesztési sorrendben);

- hosszú lejáratú kötelezettségek (tartósan, az egy évnél hosszabb lejáratú, ill. tárgyévi mérlegfordulópontot követően egy éven belül még le nem járó kötelezettségek);

- rövid lejáratú kötelezettségek (az egy évnél rövidebb lejáratú, ill. tárgyévi mérlegfordulópontot követően egy éven belül lejáró kötelezettségek). 


\begin{tabular}{|c|l|}
\hline Szállítók & $\begin{array}{l}\text { A szállítók által már teljesített, de a vál- } \\
\text { lalkozás által még ki nem fizetett ösz- } \\
\text { szeg aránya a rövid lejáratú kötelezett- } \\
\text { ségeken belül. }\end{array}$ \\
\hline$\frac{\text { Vältótartozások }}{\text { Rövid lejáratú kötelezettségek összesen }} \times 100$ & $\begin{array}{l}\text { A váltóval kiegyenlített tartozások és } \\
\text { kamatjainak aránya a rövid lejáratú kö- } \\
\text { telezettségeken belül. }\end{array}$ \\
\hline$\frac{\text { Rövid lejáratú hitelek }}{\text { Rövid lejáratú kötelezettségek összesen }} \times 100$ & $\begin{array}{l}\text { Pénzintézettől kapott rövid lejáratú hi- } \\
\text { telek aránya a rövid lejáratú kötelezett- } \\
\text { ségeken belül. }\end{array}$ \\
\hline$\frac{\text { Rövid lejáratú kölcsönök }}{\text { Rövid lejáratú kötelezettségek összesen }} \times 100$ & $\begin{array}{l}\text { Nem hitelintézettöl kapott rövid lejá- } \\
\text { ratú kölcsönök aránya a rövid lejáratú } \\
\text { kötelezettségeken belül. }\end{array}$ \\
\hline$\frac{\text { Egyéb rövid lejáratú kötelezettségek }}{\text { Rövid lejáratú kötelezettségek összesen }} \times 100$ & $\begin{array}{l}\text { Az elözókbe be nem sorolható rövid le- } \\
\text { járatú kötelezettségek aránya a rövid le- } \\
\text { járatú kötelezettségeken belül. }\end{array}$ \\
\hline
\end{tabular}

Jellemző az áruszállításból és szolgáltatásokból (szállítóktól származó) és a hitelfelvételből (hitelezőktől származó) adódó kötelezettségek külön-külön történő vizsgálata, hiszen forrásukon kívül azok felhasználási jellege is jelentősen eltér.

A szállítóállomány elemzése hasonlóan történik, mint a vevőállomány esetében. Részleteit lásd a 7. fejezetben.

A hitelállomány elemzése történhet a hitelstruktúra, ill. fedezeti mutatók és likviditási mutatók segítségével. (Utóbbiakat lásd az 5. fejezetben.) Míg a hosszú lejáratú hitelek esetében a tárgyévi nyitó és záró állomány összevetése célszerü, addig a rövid lejáratú hitelek változékonysága miatt ezek esetében célszerü átlagokat számolni. A korábban már bemutatott struktúramutatókon felül a 4.16. táblázat mutatja be a még használatos hitelstruktúra mutatókat.

\subsection{6. táblázat Hitelstruktúra-mutatók}

\begin{tabular}{|c|l|}
\hline Mutató képlete & \multicolumn{1}{c|}{ Mutató jelentése } \\
\hline$\frac{\text { Hitelek }}{\text { Források összesen }} \times 100$ & $\begin{array}{l}\text { Rövid és hosszú lejáratú hitelek aránya } \\
\text { a forrásokon belül. }\end{array}$ \\
\hline$\frac{\text { Hosszú lejáratú hitelek }}{\text { Források összesen }} \times 100$ & $\begin{array}{l}\text { Hosszú lejáratú hitelek (és kölcsönök) } \\
\text { aránya a forrásokon belül. }\end{array}$ \\
\hline$\frac{\text { Rövid lejáratú hitelek }}{\text { Források összesen }} \times 100$ & $\begin{array}{l}\text { Rövid lejáratú hitelek (és kölcsönök) } \\
\text { aránya a forrásokon belül. }\end{array}$ \\
\hline$\frac{\text { Forgóeszközhitelek }}{\text { Hitelek összesen }} \times 100$ & $\begin{array}{l}\text { Forgóeszközöket finanszírozó hitelek } \\
\text { aránya a teljes hitelállományon belül. }\end{array}$ \\
\hline$\frac{\text { Beruházási hitelek }}{\text { Hitelek összesen }} \times 100$ & $\begin{array}{l}\text { Beruházásokat finanszírozó hitelek ará- } \\
\text { nya a teljes hitelállományon belül. }\end{array}$ \\
\hline
\end{tabular}


A vállalkozások hitelállományának összetétele nemzetgazdasági ágazatonként mutat jellegzetességeket. Míg egy termelö, ipari vállalat esetében jellemzően a beruházási célú, hosszabb lejáratú hitelek vannak jelen nagyobb arányban, addig egy kereskedelmi vállalkozás esetében inkább a készleteket, forgóeszközöket finanszírozó, rövidebb lejáratú hitelek.

\subsection{Az eszközök és források egymással történő összehasonlítása}

A 4.1-es fejezetben áttekintett vertikális elemzést biztosító mutatók mellett használatosak a horizontális mutatók is, melyek a vállalkozás vagyonát és annak finanszírozását, azaz az eszközöket és a forrásokat állítják egymással szembe és elemzik különböző szempontok szerint.

horizontális elemzés mutatói $(A)=\frac{\text { eszköz oldali csoport vagy mérlegtétel }}{\text { forrás oldali csoport vagy mérlegtétel }} \times 100$

horizontális elemzés mutatói $(B)=\frac{\text { forrás oldali csoport vagy mérlegtétel }}{\text { eszköz oldali csoport vagy mérlegtétel }} \times 100$

Jellemzően ebbe az elemzési eszköztárba tartoznak az adósságállomány és a likviditási helyzet mutatói (5. fejezet), a jövedelmezőségi (6. fejezet) és hatékonysági (7. fejezet) mutatók, a készlet- (8. fejezet) és tárgyieszköz-gazdálkodás (9. fejezet) mutatóinak egy része, amelyek azonban a későbbi fejezetekben kerülnek bemutatásra. E fejezet csak az ezekbe nem tartozó mutatókkal foglalkozik.

Általánosságban véve a fedezetiarány-mutatók az alábbi felépítést követik. Ezek megmutatják, hogy valamely vagyonelemet adott forrásból milyen mértékben finanszíroz a vállalkozás.

$$
\frac{\text { Tőkefajta }}{\text { Eszközfajta }} \times 100
$$

A vagyonfedezet a teljes vagyonra vonatkoztatottan megadja, hogy a saját tőke milyen mértékben képes a vállalkozás vagyonát finanszírozni. Nem szerencsés, ha értéke 30\% alá csökken, viszont annál kedvezőbb a vállalkozás helyzete, minél magasabb ennek a mutatónak az értéke.

$$
\frac{\text { Saját tőke }}{\text { Eszközök összesen }} \times 100
$$

A vállalkozás számára hosszú távon rendelkezésre álló források befektetett eszközöket finanszírozó mértékének mutatói (fedezeti mutatók) hasonlóak az előző mutatóhoz.

Az idegen tőke-fedezet a tőkeáttétel azon mutatója, amely azt jelzi, hogy a vállalkozás eszközeinek mekkora részét finanszírozza idegen forrásokból. A mutató 30\% (vagy maximum 50\%) körül megfelelőnek mondható. 


$$
\frac{\text { Kötelezettségek (Idegen tőke) }}{\text { Eszközök összesen }} \times 100
$$

A kötelezettségfedezet a vállalkozás követeléseit és kötelezettségeit állítja szembe. Megmutatja, hogy szükséges-e a kötelezettségek finanszírozásába új forrásokat bevonni avagy képesek-e fedezni a vállalkozás követelései a kötelezettségeit. Amennyiben kisebb, mint 100\%, akkor szükséges további források bevonása.

$$
\frac{\text { Követelések összesen }}{\text { Kötelezettségek összesen }} \times 100
$$

\subsection{Working capital - müködő tőke - forgótőke - nettó forgótőke}

A working capital az angolszász szakirodalomból származó kifejezés. Bár szó szerinti fordítása müködő tőkét jelent, azonban ennek használata tartalmát tekintve teljesen helytelen lenne. Tartalmi megfelelője a magyar szakirodalomban forgótőkeként vagy nettó forgótőkeként található meg, bár ezek is különböznek egymástól. Valójában az angol-szász szakirodalom a forgótőkét érti a working capital alatt.

Annak érdekében, hogy érthető legyen a különbség az egyes fogalmak között, fontos azok pontos definíciójának meghatározása:

- működő tőke: a tulajdonosok által a tárgyévben a vállalkozás számára a saját tőkébe rendelkezésre bocsátott források összessége;

- forgótőke: a forgóeszközök (rövid lejáratú eszközök) azon része, amelyet a vállalkozás saját forrásból finanszíroz (az angol-szász számviteli szabályok szerinti working capital);

- nettó forgótőke: a forgóeszközök (rövid lejáratú eszközök) és a rövid lejáratú kötelezettségek különbözete, vagyis a forgóeszközök azon része, amelyet a vállalkozás tartós forrásokkal finanszíroz (4.17. táblázat) (a magyar szakirodalomban használt megközelítés).

4.17. táblázat A forgótöke meghatározása

\begin{tabular}{|l|l|}
\hline Befektetett eszközök & $\begin{array}{l}\text { Saját tőke és hosszú lejáratú } \\
\text { kötelezettségek }\end{array}$ \\
\cline { 2 - 3 } Forgóeszközök & Rövid lejáratú kötelezettségek \\
\hline
\end{tabular}

Forrás: Zéman - Béhm (2016)

Azaz képlettel megfogalmazva a forgótőkét:

$$
\text { Forgótőke = Forgóeszközök }- \text { Rövid lejáratú kötelezettségek }
$$

A nettó forgótőke és a forgótőke alapvető különbsége abban fogható meg, hogy előbbinél a forgóeszközök finanszírozásában az idegen források is megengedhetők. 
Alapvetően kijelenthetjük, hogy ha a forgótőke értéke pozitív, akkor ez kedvező a vállalkozás szempontjából, mert forgóeszközeinek egy részét képes tartós forrásokból finanszírozni. Kimondottan kedvezőtlen, ha a forgótőke értéke negatív, mert ebben az esetben a vállalkozás kénytelen a befektetett eszközök egy részét rövid lejáratú kötelezettségekből finanszírozni, és a forgóeszközök nem ad megfelelő fedezetet a rövid lejáratú kötelezettségek rendezésére.

A vállalkozások finanszírozási stratégiái között az ún. illeszkedési elv alapján három különböző lehetőséget különböztetünk meg:

- Szolid stratégia: a vállalkozás teljes mértékben megfelel az illeszkedési elv követelményének, azaz a nettó forgótőke éppen a tartós forgóeszköz-lekötés finanszírozására elegendö;

- konzervatív stratégia: a vállalkozás ebben az esetben olyannyira óvatos, hogy az átmeneti eszközlekötés egy részét is inkább tartós forrásból valósítja meg (bár ez magasabb költségekkel járhat számára);

- agresszív stratégia: a tartós eszközök egy részét is átmeneti eszközökkel finanszírozza a vállalkozás - ami negatív forgótőkével jár együtt és meglehetősen kockázatos.

\section{Forrásjegyzék}

1) Béhm, I. (1998). Gazdasági-pénzügyi ismeretek. Budapest: Perfekt Gazdasági Tanácsadó, Oktató és Kiadó Zrt.

2) Birher, I., Pucsek, J., Sándor, L., Sztanó, I. (2009). Vállalkozások tevékenységének gazdasági elemzése. Budapest: Perfekt Gazdasági Tanácsadó, Oktató és Kiadó Zrt.

3) Gyulai, L. (2013). A kis- és középvállalkozások üzleti finanszírozása. Budapest: BGF.

4) Jacobs, O. H., Oestreicher, A. (2000). Mérlegelemzés. Budapest: Kossuth Kiadó.

5) Sebes, J. (2013). Elemzés - Vállalati elemzés - Mérlegelemzés. Budapest: Aura Kiadó.

6) Zéman, Z., Béhm, I. (2016). A pénzügyi menedzsment controll elemzési eszköztára. Budapest: Akadémiai Kiadó. 


\section{A pénzügyi helyzet elemzése rövid és hosszú távon}

A vállalkozás pénzügyi helyzetét két időhorizonton szokás vizsgálni, rövid, illetve hosszú távon. Ennek megfelelően megkülönböztetjük az ún. likviditást mérő mutatók csoportját (rövid távú, 1 évnél rövidebb időtávú elemzés) - kiegészítve a likviditási mérleggel - valamint az adósságállomány vizsgálatát célzó mutatók csoportját (hosszú távú, 1 évnél hosszabb időtávú elemzés). Jellemzően mindkét csoport esetében horizontális típusú mutatókat használunk, azaz a mérleg eszköz és forrás oldaláról is bevonunk csoportokat, tételeket. Ugyanakkor a mérlegtételeken túl az eredménykimutatás egyes elemei is felhasználásra kerülhetnek a pénzügyi helyzet elemzésekor, ill. a cash flow-kimutatás adatainak vizsgálata is számos fontos információt tartalmazhat a kérdéskör feltárása során. Az előbbieken túl ebben a fejezetben tárgyaljuk még a piaci megtérülési mutatókat, amelyek befektetői szempontból szintén fontosak.

\subsection{Likviditás elemzése mutatók segítéségével}

A likviditás a vállalkozás azon képességét fejezi ki, hogy képes rövid távon felmerülő kötelezettségeinek elöre meghatározott és korábban elfogadott időpontban, folyamatosan, elmaradások nélkül eleget tenni. Ilyen értelemben a vállalkozás fizetőképességét értjük a fogalom alatt (diszpozitív likviditás). Más megközelítésben a likviditás fogalma alatt azt is értjük, hogy a vállalat milyen mértékben rendelkezik olyan eszközökkel, amelyek rövid időn belül, gyorsan vagy adott esetben csak hosszabb időtáv alatt és lassabban tehetők készpénzzé, ezáltal pedig milyen ütemben biztosítható a vállalkozás fizetőképessége (strukturális likviditás).

Mivel a likviditás rövidtávon értelmezendö, ezért a mérlegben eszköz oldalon a forgóeszközök, forrás oldalon pedig a folyó fizetési kötelezettségek képezik a vizsgálódás tárgyát, jellemzően ezek egymáshoz való viszonyítása történik meg mutatók formájában. Az időhorizontot ebben a tekintetben a likviditási mérleg fogja növelni a fejezet későbbi részében. A likviditási mutatók értékelésére a hitelintézetek különösen nagy hangsúlyt fektetnek azért, hogy vajon egy esetleges hitel folyósítása során a vállalkozás képes lesz-e annak tőketörlesztését és kamattörlesztését megfelelö ütemben teljesíteni. Ennek elsősorban a rövid lejáratú hitelek kapcsán van jelentősége.

A nettó likviditás fogalma alatt a rövidtávon jelentkező kötelezettségek, ill. céltartalékok, valamint a rövidtávon könnyen pénzzé tehető eszközök (értékpapírok, rövid távú követelések, pénzeszközök) különbségét értjük. Értéke pozitív és negatív is lehet, azonban önmagában ennek ismerete nem elégséges információ a vállalkozás helyzetének megítéléséhez, hiszen különböző időpontokban jelentősen változhat. Kizárólag annak ismeretében tudjuk érdemben használni, ha tudjuk, hogy a vállalkozás a közeli jövőben milyen realizálható bevételekkel és felmerülő kiadásokkal fog szembesülni, azaz a jelenlegi nettó likviditása a jövőben miként változik és megfelelő tartalékai lesznek-e a jövőben a felmerülő kiadásainak fedezésére. Ezzel együtt amennyiben értéke jellemzően pozitív, akkor a vállalkozás fizetőképessége stabil, rugalmasan tudja kezelni fellépő fizetési kötelezettségeit. Jellemzően negatív értéke tartós fize- 
tőképtelenségre utal, ami a vállalkozás megítélését pl. banki hitelezés szempontjából kedvezőtlenné teszi, hiszen nem képes felmerülő kötelezettségeinek megfelelő rugalmassággal eleget tenni.

Nettó likviditás

$$
\begin{aligned}
& \text { = Rövid lejáratú követelések + Értékpapírok + Pénzeszközök } \\
& \text { - Rövid lejáratú kötelezettségek - Rövid távra képzett céltartalékok }
\end{aligned}
$$

A likviditási rátákat több fokozatban szokás értékelni, melyet az 5.1. táblázat foglal össze.

\begin{tabular}{|c|c|c|}
\hline Likviditás foka & Mutató & Mutató jelentése \\
\hline $\begin{array}{l}\text { Likviditási mutató } \\
\text { I. }\end{array}$ & $\frac{\text { Forgóeszközök }}{\text { Rövid lejáratú kötelezettségek }}$ & $\begin{array}{l}\text { A likvid eszközök } \\
\text { és likvid források } \\
\text { aránya. }\end{array}$ \\
\hline $\begin{array}{l}\text { Likviditási mutató } \\
\text { II. (Likviditási } \\
\text { gyorsráta) }\end{array}$ & $\begin{array}{c}\frac{\text { Forgóeszközök }- \text { Készletek }}{\text { Rövid lejáratú kötelezettségek }} \\
\text { vagy } \\
\frac{\text { Követelések + Értékpapírok + Pénzeszközök }}{\text { Rövid lejáratú kötelezettségek }}\end{array}$ & $\begin{array}{l}\text { A likvid eszközök } \\
\text { és a nehezebben } \\
\text { pénzzé tehetö } \\
\text { készletek különb- } \\
\text { ségének, ill. a lik- } \\
\text { vid forrásoknak az } \\
\text { aránya. }\end{array}$ \\
\hline $\begin{array}{l}\text { Likviditási mutató } \\
\text { III. (Pénzhányad) }\end{array}$ & $\begin{array}{c}\frac{\text { Forgóeszközök }- \text { Készletek - Követelések }}{\text { Rövid lejáratú kötelezettségek }} \\
\text { vagy } \\
\frac{\text { Értékpapírok + Pénzeszközök }}{\text { Rövid lejáratú kötelezettségek }}\end{array}$ & $\begin{array}{l}\text { A teljes mértékben } \\
\text { likvidnek tekint- } \\
\text { hető eszközök és a } \\
\text { likvid források ará- } \\
\text { nya. }\end{array}$ \\
\hline
\end{tabular}

\section{1. táblázat Likviditási ráták}

A Likviditási mutató I. az egy éven belül pénzzé tehető eszközök, ill. 1 éven belül felmerülő kötelezettségek aránya, mely arra ad választ, hogy rövidtávon fizetőképes lehet-e a vállalkozás. Ha értéke 1-nél magasabb, akkor elfogadhatónak minősíthető, ugyanis 1 alatti érték mellett előfordulhat a vállalkozás rövid távú fizetöképtelensége, hiszen rövid távú eszközei képtelenek fedezni a rövid lejáratú kötelezettségeit. Az sem szerencsés, ha értéke túl magas, mivel akkor felmerül egy indokolatlanul konzervatív, a vállalkozás eszközeit nem megfelelően befektető üzletmenet lehetősége. A hitelintézeti értékelések során az 1,3 alatti értéket rossznak, az 1,31,8 közötti értéket közepesnek, míg az 1,8 feletti értéket jónak tartják, sőt hitelkérelmek esetében a 2 feletti érték is sok esetben elvárás. Amennyiben értéke 1 alá esik, az akut fizetöképességi problémát jelent. 
A Likviditási mutató II. a számlálóban nem szerepelteti a forgóeszközök között a készleteket abból a megfontolásból, hogy ezek között lehetnek olyanok, amelyek átlagos üzleti körülmények között nehezen vagy csak hosszú idő alatt tehetők készpénzzé, ezért nem vonhatók be könnyen a rövid távú kötelezettségek finanszírozásába. Mivel számlálója értelem szerủen kisebb, mint a Likviditási mutató I. számlálója, ezért a hányados értéke is kisebb, de elfogadható értéknek itt is az 1-et vagy annál magasabb értéket szokás megjelölni. Elsősorban kereskedelmi vállalkozások esetében elfogadható akár az 1 alatti érték is. Esetükben ennek oka az, hogy esetükben kimondottan magas az árukészletek nagysága, amelynek levonása a számlálót jelentősen csökkentheti - ez azonban nem jelent szükségszerűen rossz fizetőképességet.

A Likviditási mutató III. a vállalkozás azonnali likviditását mutatja be, hiszen a számlálóban már valóban csak az értékpapírokat és pénzeszközöket szerepelteti, azaz azokat az eszközöket, amelyek gyakorlatilag azonnal készpénzzé tehetők és azonnal felhasználhatók a kötelezettségek kiegyenlítésére. 1 feletti érték esetén nagyon nagyfokú likviditási biztonságról lehet beszélni, azonban ekkora érték sok esetben indokolatlan is lehet - ez attól függ, hogy a más típusú eszközök milyen gyorsan tehetők pénzzé. Minimálisan elvárható, hogy a 0,2-es értéket érje el. 0,01-es érték esetén csődhelyzetről beszélhetünk.

A három klasszikus likviditási rátán felül további mutatók alkalmazhatóak a likviditás elemzésére, melyeket az 5.2. táblázat foglal össze.

\section{2. táblázat A likviditás elemzésére használatos egyéb mutatók}

\begin{tabular}{|c|c|c|}
\hline $\begin{array}{c}\text { Mutató megne- } \\
\text { vezése }\end{array}$ & Mutató & $\begin{array}{c}\text { Mutató jelen- } \\
\text { tése }\end{array}$ \\
\hline Szolvencia & $\frac{\text { Összes eszköz }}{\text { Külső idegen források }}$ & $\begin{array}{l}\text { A vállalkozás } \\
\text { összes eszközé- } \\
\text { nek aránya a } \\
\text { külső források- } \\
\text { hoz képest. }\end{array}$ \\
\hline $\begin{array}{l}\text { Dinamikus likvi- } \\
\text { ditás }\end{array}$ & $\frac{\text { Üzemi - üzleti tevékenység eredménye }}{\text { Rövid lejáratú kötelezettségek }}$ & $\begin{array}{l}\text { Tárgyévi üzemi- } \\
\text { üzleti eredmény } \\
\text { aránya a rövid le- } \\
\text { járatú kötelezett- } \\
\text { ségekhez képest. }\end{array}$ \\
\hline $\begin{array}{l}\text { Rövid távú el- } \\
\text { adósodottság }\end{array}$ & $\frac{\text { Rövid lejáratú kötelezettségek - likvid eszközök }}{\text { Értékesítés nettó árbevétele }}$ & $\begin{array}{l}\text { A rövid lejáratú } \\
\text { kötelezettségekre } \\
\text { nyújtott árbevé- } \\
\text { teli fedezet ará- } \\
\text { nya. }\end{array}$ \\
\hline Időtartam mutató & $\frac{\text { Vevők + Likvid értékpapírok + Pénzeszközök }}{\text { Éves átlagos működési kiadás/365 }}$ & $\begin{array}{l}\text { A leginkább lik- } \\
\text { vid eszközök } \\
\text { aránya a napi át- } \\
\text { lagos müködési } \\
\text { kiadásokhoz ké- } \\
\text { pest. }\end{array}$ \\
\hline
\end{tabular}


Szolvensnek tekintjük azt a vállalatot, amelynél az eszközök összértéke meghaladja a külső, idegen források nagyságát. Használjuk a tartós fizetőképesség szinonimájaként is.

A dinamikus likviditási mutató az eredménykimutatásból használja fel az üzemi-üzleti tevékenység eredményének értékét és azt fejezi ki, hogy képes-e a vállalat tárgyévi üzleti teljesítményével megtermelni a rövid lejáratú kötelezettségeinek teljesítéséhez szükséges pénzmenynyiséget. Azt tekintjük elfogadhatónak, ha értéke 0,5 feletti.

A rövid távú eladósodottság mutató szintén az eredménykimutatásból veszi az értékesítés nettó árbevételét, és ehhez méri a rövid lejáratú kötelezettségeket (csökkentve a likvid eszközök értékével). Arra ad választ, hogy az értékesítés nettó árbevétele milyen mértékben képes fedezni az 1 éven belül felmerülő kötelezettségeket. Kedvező, ha értéke kisebb, mint 1.

Az időtartam mutató azt méri, hogy a leginkább likvid eszközök (vevők, likvid értékpapírok és a pénzeszközök) milyen mértékben képesek a folyó tevékenység folyamatos, egy napra jutó finanszírozására. Azaz tulajdonképpen azt szemlélteti, hogy a vállalkozás ezekből a forrásokból hány napon keresztül tudná finanszírozni a működését, ha további bevételei nem lennének.

A likviditási mutatók használatának egyaránt vannak előnyei és hátrányai is. Egyik legfontosabb előnyük abban rejlik, hogy egyszerüen alkalmazhatóak, gyorsan számíthatók, értelmezésük sem okoz különösebb nehézséget, emellett közismertek. Fontos hangsúlyozni az értelmezés során, hogy a konkrét számértékek önmagukban nem elégségesek a megfelelő következtetések levonására, szükséges elemezni azt, hogy milyen jelenség húzódik meg az egyes értékek mögött, ill. hosszabb időhorizonton vizsgálva miként változtak az egyes mutatók.

Hátrányukként fontos megemlíteni, hogy ezek a mutatók a mérleg-fordulónapi adatok felhasználásával készülnek, azaz az ebben az időpillanatban fennálló állapotot tükrözik, vagyis statikus adatnak minősíthetők. Ennek figyelmen kívül hagyása azt a veszélyt hordozhatja magában, hogy az elemzett értékek szinte pillanatokon belül változhatnak attól függően, hogy a vállalkozás esetleg új bevételekhez jut, vagy új kötelezettségei keletkeznek. Tehát egy teljes gazdasági évre ezekből a mutatókból nem vonhatunk le messzemenő következtetéseket. Ráadásul a mutatók értékei könnyen befolyásolhatók például valamely kifizetés vagy beszerzés elhalasztásával. Ezért ajánlatos a likviditási helyzet folyamatos nyomon követése, a mutatók rendszeres számítása éven belül többször is.

\subsection{Likviditási mérleg}

A likviditási mérleg logikája szerint az eszköz, illetve a forrás oldalon lévő tételek kerülnek egymással szembe állításra csakúgy, mint a likviditási mutatók többsége esetében. Azonban a csoportosítás a korábbiaktól bizonyos mértékben eltér. Szokásos a 3, 4, 5 fokozatú likviditási mérleg használata is, ami attól függ, hogy milyen részletezettséggel kerülnek felbontásra az egyes eszközök és források. A felbontás alapja az eszközök esetében azok pénzzé tehetőségének mértéke (mobilitása), a források esetében pedig azok lejárati ideje, esedékessége. Az azonos időhorizonton értelmezhető elemek összevetésére ad lehetőséget a likviditási mérleg. 
Amíg a likviditási mutatók csak az 1 évnél rövidebb időhorizonton esedékes tételeket foglalták magukba, addig a likviditási mérleg ennél hosszabb időhorizontot is felölel, tulajdonképpen átvezet már az adósságállomány vizsgálatával foglalkozó mutatók témaköréhez is.

Jelen fejezetben a 4 fokozatú likviditási mérleg bemutatására kerül sor, mely egyúttal a leggyakrabban alkalmazott is (5.3. táblázat).

\section{3. táblázat A 4 fokozatú likviditási mérleg egy lehetséges sémája}

\begin{tabular}{|c|c|}
\hline Eszközök & Források \\
\hline $\begin{array}{l}\text { I. Azonnal pénzzé tehető eszközök } \\
-\quad \text { Készpénz } \\
-\quad \text { Látra szóló bankbetétek, értékpapí- } \\
\quad \text { rok }\end{array}$ & $\begin{array}{l}\text { I. Azonnal esedékes kötelezettségek } \\
\text { - } \quad \text { Szállítóállomány azonnal és } 10 \text { na- } \\
\text { pon belül esedékes része } \\
\text { - } \\
\text { Egyéb rövid lejáratú kötelezettségek } \\
\text { (adó, bér, TB) }\end{array}$ \\
\hline $\begin{array}{l}\text { II. Egy éven belüli pénzzé tehető eszközök } \\
-\quad \text { Saját részvények } \\
-\quad \text { Egy éven belüli vevőkövetelések } \\
-\quad \text { Váltó és egyéb követelések } \\
-\quad \text { Egy éven belül mobilizálható készle- } \\
\text { - } \\
\text { - } \\
\text { Aktív idöbeli elhatárolások } \\
\text { - Követelések kapcsolt és egyéb része- } \\
\text { sedési viszonyban lévő vállalkozás- } \\
\text { sal szemben }\end{array}$ & 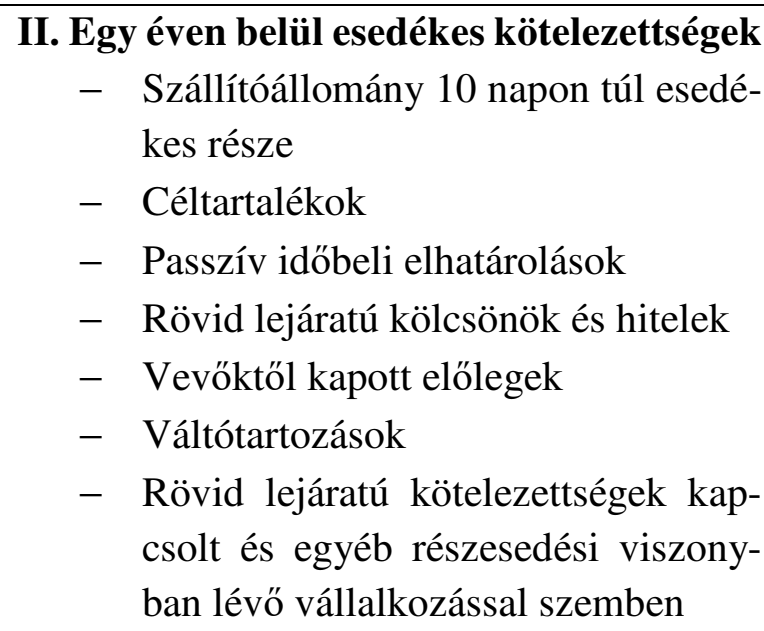 \\
\hline $\begin{array}{l}\text { III. Egy éven túl pénzzé tehető eszközök } \\
-\quad \text { Immobil, elfekvő készletek } \\
-\quad \text { Egy éve lejárt követelések } \\
-\quad \text { Minden más egy éven túli tétel }\end{array}$ & $\begin{array}{l}\text { III. Egy éven túl esedékes kötelezettségek } \\
-\quad \text { Hátrasorolt kötelezettségek } \\
-\quad \text { Hosszú lejáratú kötelezettségek }\end{array}$ \\
\hline IV. Befektetett eszközök & IV. Saját tőke \\
\hline$\sum$ Összes eszköz & \\
\hline
\end{tabular}

Forrás: Bíró és mtsai. (2016) alapján

Fontos arra felhívni a figyelmet, hogy a likviditási mérleg elkészítéséhez szükségesek a mérleg információin túl kiegészítő információk, amelyek az időhorizont szerinti pontos besorolást lehetővé teszik (pl. belső nyilvántartásokból, beszámoló kiegészítő mellékletéből). A likviditási mérleg megfelelő kategóriáiból hányadosok képezhetők, melyek számlálójában a likviditási eszközcsoportok, nevezőjében a likviditási forrás csoportok szerepelnek. Ezekre a mutatókra is érvényesek azok a hátrányok, amelyek a likviditási mutatóknál felsorolásra kerültek, azaz ezeket is évente több alkalommal célszerü értékelni. 
Az egyes eszköz és forráskategóriákból képzett különbségek segítségével elemezhető a likviditási többlet, ill. hiány is, továbbá célszerü aggregáltan, több kategóriát egymással összevon$\tan$ is elemezni.

$$
\begin{gathered}
\text { Likviditási kategória I. = } \frac{\text { Likvid eszközök I. }}{\text { Likvid források I. }} \\
\text { Likviditási kategória II. }=\frac{\text { Likvid eszközök I. +II. }}{\text { Likvid források I. +II. }} \\
\text { Likviditási kategória III. }=\frac{\text { Likvid eszközök I. +II. +III. }}{\text { Likvid források I. +II. +III. }}
\end{gathered}
$$

A likviditási mérleg felépítéséből látható, hogy a III. és IV. kategóriák már egy éven túli tételeket tartalmaznak, melyek már szoros értelemben véve nem a likviditás, hanem az adósságállomány értékelésének témaköréhez tartoznak. A likviditási kategóriák mindegyikével kapcsolatban kijelenthető, hogy ha a hányadosok értéke 1 felett van, akkor megfelelő a vállalkozás fizetőképessége az adott szinten, míg ha 1 alatt, akkor likviditási problémákra utal.

\subsection{Likviditási problémák és kezelésük}

A likviditással kapcsolatos problémaként említhető meg, ha a vállalkozás nem képes aktuálissá váló kötelezettségeinek kiegyenlítésére, de az is, ha túlzottan nagy likvid tartalékokkal rendelkezik a fennálló rövid távú kötelezettségeihez képest. Utóbbi esetében az jelenti a problémát, hogy a vállalkozás üzletpolitikája túlzottan biztonságra törekvő, konzervatív, a túlzottan nagy mennyiségben tartott likvid eszközök pedig befektethetők lennének, amely befektetések további hozamokat eredményezhetnének a vállalkozás számára. Tulajdonképpen e hozamokról mond le a vállalkozás a túlzottan felhalmozott likvid eszközök miatt, azaz ezeket alternatív költségként foghatjuk fel.

A likviditási hiány hátrányai sokkal kézenfekvőbbek, hiszen az a vállalat, amely huzamos ideig nem képes kötelezettségeinek határidőben történő kiegyenlítésére, előbb-utóbb elveszíti hitelezői és beszállítói bizalmát, mely súlyos következményekkel járhat. Egyrészt új hiteleket nehezebben kaphat meg - ha egyáltalán megkap - és magasabb költségek (kamat) mellett, másrészt beszállítói termékeik, ill. szolgáltatásaik értékesítését és szállítását csak előzetes fizetés esetén vagy bizonyos biztosítékok rendelkezésre állása esetén hajlandóak csak megtenni. Ez még tovább rontja a vállalkozás likviditási helyzetét.

Likviditási többlet megoldása esetén a vállalkozás az alábbi módszerek közül választhat (melyekkel csökkenti lekötetlen tökéjének állományát):

- fokozza a készpénzzel történő vásárlásokat;

- a magas kamatozású hiteleket visszafizeti;

- részesedéseket vásárol más vállalkozásokban;

- fokozza az innovációs, beruházási, $\mathrm{K}+\mathrm{F}$ tevékenységét és új befektetéseket eszközöl;

- új technológiára vagy termék gyártására tér át, új piacokon jelenik meg. 
Likviditási hiány esetében a vállalkozás számára az alábbi megoldási lehetőségek állnak rendelkezésre:

- növeli készpénzért történő értékesítéseit;

- vevőitől előleget kér, ill. fogad el;

- behajtja kintlévőségeit;

- leszámítoltatja váltóit;

- eladja értékpapírjait és más vállalkozásokban meglévő részesedéseit;

- a szükségtelen tárgyi eszközeit és készleteit értékesíti;

- visszafogja a beruházásokat;

- hitelt, kölcsönt vesz fel;

- faktoráltatja (esedékesség előtt eladja) vevőállományát;

- megpróbál kockázati tőkét bevonni.

\subsection{Adósság-állomány elemzése mutatók segítéségével}

A likviditási elemzésekkel szemben az adósság-állomány elemzése a hosszú lejáratú (1 éven túl esedékes) kötelezettségek vizsgálatával foglalkozik. Célja az, hogy megvizsgálja, milyen mértékben vannak jelen a vállalkozás finanszírozásában a hosszú lejáratú, idegen forrásból származó hitelek és kölcsönök, valamint milyen fedezetük van ezeknek és eszköz oldalon mely tételeket finanszírozza ezekkel a vállalkozás. Fontos felhívni a likviditási helyzet és az adósságállomány közötti összefüggéssel kapcsolatban arra a figyelmet, hogy az adósságállomány nagyfokú növekedése az idő elörehaladtával és a törlesztési kötelezettségek fellépésével a likviditási helyzetet ronthatja. Vizsgálata egyaránt történik horizontális és vertikális mutatókkal is.

Az adósságállományt vizsgáló mutatók első csoportja az idegen források és a saját tőke arányát vizsgálja többféle megközelítésből (5.4. táblázat). (Ezek esetében az adósságállomány alatt a hosszú lejáratú adósságállományt értjük!)

5.4. táblázat Az adósságállomány arányát elemzö mutatók

\begin{tabular}{|c|c|c|}
\hline $\begin{array}{c}\text { Mutató megneve- } \\
\text { zése }\end{array}$ & Mutató & Mutató jelentése \\
\hline $\begin{array}{l}\text { Adósságállomány } \\
\text { aránya (Eladóso- } \\
\text { dottsági mutató) }\end{array}$ & $\frac{\text { Adósságállomány }}{\text { Adósságállomány }+ \text { Saját tőke }} \times 100$ & $\begin{array}{l}\text { Az adósságállo- } \\
\text { mány aránya a tar- } \\
\text { tós forrásokon belül. }\end{array}$ \\
\hline Saját tőke aránya & $\frac{\text { Saját tőke }}{\text { Adósságállomány }+ \text { Saját tőke }} \times 100$ & $\begin{array}{l}\text { A saját tőke aránya } \\
\text { a tartós forrásokon } \\
\text { belül. }\end{array}$ \\
\hline $\begin{array}{l}\text { Adósságállomány } \\
\text { fedezettsége }\end{array}$ & $\frac{\text { Saját tőke }}{\text { Adósságállomány }}$ & $\begin{array}{l}\text { A saját tőke aránya } \\
\text { az adósságállo- } \\
\text { mányhoz képest. }\end{array}$ \\
\hline $\begin{array}{l}\text { Idegen tőke / saját } \\
\text { tőke aránya }\end{array}$ & $\frac{\text { Adósságállomány }}{\text { Saját tőke }}$ & $\begin{array}{l}\text { Az adósságállo- } \\
\text { mány aránya a saját } \\
\text { tőkéhez képest. }\end{array}$ \\
\hline
\end{tabular}


Az adósságállomány aránya és a saját tőke aránya mutatók egymás komplementerei, intenzitási mutatók. Jellemzően nem csak egy időpontra, hanem hosszabb időtávon szokás elemezni alakulásukat. Általánosságban az adósságállomány aránya akkor tekinthető elfogadhatónak, ha értéke $60 \%$ alatti, ennek megfelelően a saját tőke aránya mutató pedig $40 \%$ feletti. Értelemszerủen annál kedvezőbb egy vállalkozás helyzete, minél magasabb a saját tőke arány mutatója, ami azt jelentheti, hogy lehetnek még tartalékai új hitelek felvételét illetően. A mutatók értékelésekor figyelembe kell venni a vállalkozás éppen aktuális piaci helyzetét, hiszen előfordulhat, hogy egy új, komolyabb beruházás vagy fejlesztés miatt hirtelen megnő az adósságállomány aránya, amely kedvezőtlennek tủnik, de mégis indokolt lehet, ha a jövőben komoly megtérülés várható.

Az adósságállomány fedezettsége mutató a megelőző két arányszámhoz hasonlóan, csak más megközelítésben méri a saját tőke és az adósságállomány arányát, tulajdonképpen azt mondja meg, hogy egy forintnyi adósságra hány forint saját tőke jut a vállalkozás forrásain belül. Értéke annál kedvezőbb, minél magasabb - az előzőeknek megfelelően legalább 0,67 feletti. Ennek a mutatónak épp ellentéte az idegen tőke / saját tőke mutató, amely pedig annál kedvezőbb, minél kisebb értéket vesz fel - legalább 1,5 vagy az alatti. Mindkét mutató tulajdonképpen a tőkeáttételt méri.

Ezeket a mutatókat egészítheti ki az adósságállomány változásának különbözete, illetve az eladósodás nagysága mutatók (5.5. táblázat).

\section{5. táblázat Az adósságállomány és eladósodás mértékének mutatói}

\begin{tabular}{|l|c|l|}
\hline $\begin{array}{c}\text { Mutató megneve- } \\
\text { zése }\end{array}$ & \multicolumn{1}{|c|}{ Mutató } & Mutató jelentése \\
\hline $\begin{array}{l}\text { Adósságállomány } \\
\text { változása }\end{array}$ & $\begin{array}{l}\text { Kötelezettségek záróállománya } \\
- \text { Kötelezettségek nyitóállománya }\end{array}$ & $\begin{array}{l}\text { Kötelezettségek } \\
\text { tárgyévi záró és nyi- } \\
\text { tóállományának kü- } \\
\text { lönbözete. }\end{array}$ \\
\hline Eladósodás & Összes eszköz - Saját tőke & $\begin{array}{l}\text { A források között az } \\
\text { idegen források ér- } \\
\text { téke. }\end{array}$ \\
\hline $\begin{array}{l}\text { Eladósodottság } \\
\text { foka }\end{array}$ & Kötelezettségek \\
\cline { 2 - 3 } & Összes eszköz & $\begin{array}{l}\text { Az idegen források } \\
\text { aránya a vállalkozás } \\
\text { teljes vagyonához } \\
\text { képest. }\end{array}$ \\
\hline
\end{tabular}

Fel kell hívni a figyelmet arra az 5.5. táblázat mutatóival kapcsolatban, hogy ezek a teljes kötelezettségállományt mérik (azaz az 1 évnél rövidebb és hosszabb lejáratú kötelezettségeket egyaránt), de számíthatók csak a hosszú lejáratú kötelezettségekre is.

Egy eredménykimutatásból vett adatot, az értékesítés nettó árbevételét használja fel az árbevételre vetített eladósodottság mutatója, amely azt vizsgálja, hogy milyen mértékben nyújt fedezetet a vállalkozás likvid forgóeszközök értékével csökkentett kötelezettségeire (hosszú és rövid lejáratú egyaránt) a nettó árbevétel. Értéke minél alacsonyabb, annál kedvezőbb, hiszen 
ebben az esetben a vállalkozásnak kevésbé kell más egyéb saját vagy idegen forrásaiból finanszíroznia tevékenységét, valamint értékesítenie likvid eszközeit, hanem a rendes üzletmenet jó részben képes biztosítani a kötelezettségek fedezetét. A mutató nem értelmezhető, ha negatív, ekkor ugyanis a vállalkozás likvid forgóeszközeinek nagysága meghaladja a kötelezettségeit, azaz a vállalkozás számára különösebb gondot nem jelenthet a kötelezettségek finanszírozása.

\section{Kötelezettségek - likvid forgóeszközök \\ Értékesítés nettó árbevétele}

Fontos figyelemmel követnie a vállalatnak azt is, hogy a fennálló hosszú lejáratú adósságaiból adódó fizetési kötelezettségeit milyen mértékben tudja teljesíteni, mekkora fedezet áll ehhez rendelkezésre. Ezt számszerüsíti az adósságszolgálati fedezeti mutató, mely az adózott eredmény és az elszámolt értékcsökkenési leírás összegét viszonyítja (melyek forrása az eredménykimutatás) az adósságok törlesztéséből adódó tőke- és kamattörlesztés esedékes mértékéhez. Tulajdonképpen azt méri, hogy a vállalkozás éves eredménye milyen mértékben nyújt fedezetet az egy évnél hosszabb lejáratú adósságok törlesztésére, ill. választ ad arra, hogy ezen felül milyen mértékben marad forrása a vállalkozásnak más tevékenységei finanszírozására a tárgyévi eredményböl. Mivel ez utóbbi is célja kell, hogy legyen a vállalkozásnak, ezért elvárt értéke mindenképpen 1 feletti, de ideálisabb, ha 1,3 feletti.

\section{Adózott eredmény + Elszámolt értékcsökkenés \\ Hosszú lejáratú kölcsönök éves esedékes törlesztése és kamata}

Tekintettel arra, hogy a vállalkozás vagyonában hosszútávon jelenlévő elemeket a befektetett eszközök csoportjába soroljuk, fontos azt is elemezni, hogy ezeknek a fedezete milyen mértékben megoldott a hosszú lejáratú forrásokból. Erre szolgálnak az ún. befektetett eszközök fedezeti mutatói (5.6. táblázat).

\section{6. táblázat Befektetett eszközök fedezetének mutatói}

\begin{tabular}{|c|l|}
\hline \multicolumn{1}{|c|}{ Mutató } & \multicolumn{1}{c|}{ Mutató jelentése } \\
\hline Saját tőke + Hátrasorolt kötelezettségek \\
\hline Befektetett eszközök & $\begin{array}{l}\text { A hosszú távú saját források } \\
\text { és hátrasorolt források ará- } \\
\text { nya a befektetett tőkéhez ké- } \\
\text { pest. }\end{array}$ \\
\hline Saját tőke + Hátrasorolt és hosszú lejáratú kötelezettségek \\
\hline Befektetett eszközök & $\begin{array}{l}\text { A hosszú távon rendelke- } \\
\text { zésre álló összes forrás ará- } \\
\text { nya a befektetett eszközök- } \\
\text { höz képest. }\end{array}$ \\
\hline
\end{tabular}

Ezek a fedezeti mutatók azt jelzik, hogy egy forintnyi befektetett eszközre hány forint hosszú távon is a vállalkozás rendelkezésére álló forrás jut. Mindenképpen az az optimális, ha a hosszú távon használt eszközöket teljes egészében hosszú távon rendelkezésre álló forrásokból fedezi egy vállalkozás, így az 5.6. táblázat második mutatójánál elvárható az 1 feletti érték. Ha az 5.6. 
táblázat két mutatója között nagy a különbség utóbbi javára, az azt jelenti, hogy a vállalkozás hosszú távon használt eszközeit nagyobb arányban idegen forrásokból és kisebb arányban saját vagy hátrasorolt forrásokból finanszírozza.

\subsection{Piaci megtérülési mutatók}

A pénzügyi elemzések közé soroljuk azokat a módszereket is, amelyek a vállalkozást a befektetők szemszögéből értékelik. Ezek feladata az, hogy képet kapjanak a (leendő) tulajdonosok arról, hogy befektetett eszközeik milyen megtérülést biztosíthatnak, ill. hogyan alakul a vállalkozás összvagyona vagy egyes vagyonelem-csoportjainak értéke. Az ezt értékelő mutatókat hívjuk piaciérték-mutatóknak.

Egy vállalkozás piaci értékének azt az összeget nevezzük, amelyet a piaci szereplők saját szabad akaratuktól vezérelve hajlandóak megadni azért, hogy a vállalkozás tulajdonosaivá válhassanak. Növekvő, fejlődő, perspektívával rendelkező vállalkozás esetében ez az összeg magasabb, mint a vállalkozás könyveiben nyilvántartott teljes eszközérték (a mutatók értéke 100\%-nál nagyobb). Az eltérés mértékét számszerüsítik a piaci érték - könyv szerinti érték arányát összevető mutatók, melyek számíthatók a vállalkozás egészére és csak egyes vagyoncsoportokra is.

$$
\begin{aligned}
& \frac{\text { Összes eszköz piaci értéke }}{\text { Összes eszköz könyv szerinti értéke }} \times 100 \\
& \frac{\text { Eszközfajta piaci értéke }}{\text { Eszközfajta könyv szerinti értéke }} \times 100
\end{aligned}
$$

Részvénytársaságok esetében használható az egy részvény piaci értékét és könyv szerinti értékét arányosító mutató. Ebben az esetben a nevezőben a részvény névértéke - vagy a saját tőke egy kibocsátott részvényre jutó értéke - szerepelhet, míg a számlálóban annak piaci árfolyama. Ideális esetben a mutató értéke 100\%-nál magasabb.

$$
\frac{\text { Egy részvény piaci értéke }}{\text { Egy részvény könyv szerinti értéke }} \times 100
$$

Szintén a részvényekhez kapcsolható mutató az árfolyam/nyereség ráta (Price-Earnings Ratio, P/E) amely azt mutatja meg, hogy ha egy befektető megveszi a vállalkozás egy részvényét, akkor a vállalkozás egy részvényre jutó tárgyévi nyereségéből hány év alatt térülne meg a befektetése. A tört nevezőjében az EPS rövidítéssel (Earnings per Share) gyakran találkozhatunk, amely önmagában is egy tört és kifejezi, hogy a vállalkozás által megtermelt és adózott eredmény a vállalkozás által kibocsátott részvényekre leosztva mekkora értéket képvisel. Értéke annál kedvezőbb, minél magasabb, hiszen ebben az esetben egységnyi tulajdonrészre magas adózott eredmény esik. Magas értéket eredményezhet, ha az adózott eredmény magas, vagy 
relatíve kevés részvény került kibocsátásra. Ugyanakkor különböző országokban eltérően számítják, amely megnehezíti a részvények EPS mutatóinak összehasonlítását.

A P/E ráta minél nagyobb, a részvény piaci árfolyama relatíve annál magasabb az EPS-hez képest. Az ilyen részvények esetében a befektetők és a piac várakozása az, hogy a jövőben a mostani, tárgyévi eredményéhez képest még magasabb eredményt lesz képes elérni a vállalkozás, azaz magasra értékelik a jövőbeni várakozásaik okán a részvény árfolyamát. $\mathrm{A} P / \mathrm{E}$ ráta magas értéke jó jövőbeni kilátásokat vetít elöre és a befektetők számára általánosságban jó megtérülést illetve pozitív jövőképet vetít előre, az ilyen papírok megvásárlása jó befektetésnek minősíthető. Ugyanakkor bizonyos befektetőknek éppen azok az értékpapírok válhatnak érdekessé, amelyek alacsony P/E rátával rendelkeznek, mert ezek relatíve alul értékeltek lehetnek és tőlük a jövőben részvényárfolyam-növekedés várható - ez nem szükségszerüen így van, ennek megállapításához plusz információk szükségesek. Ezekből adódóan a P/E rátának és az EPS-nek sincsen kimondott értéke, amely felett jónak, vagy amely alatt rossznak minősíthetjük.

$$
\begin{aligned}
& \text { EPS }=\frac{\text { Adózott eredmény }}{\text { Vállalkozás által kibocsátott részvények darabszáma }} \\
& \mathrm{P} / \mathrm{E} \text { ráta }=\frac{\text { Részvény piaci árfolyama }}{\text { Egy részvényre jutó adózott eredmény (EPS) }}
\end{aligned}
$$

Szintén részvénytársaságok értékelésére használt mutató az egy részvényre jutó osztalék aránya, amely a vállalkozás által megtermelt eredményböl a vállalkozás tulajdonosai által jóváhagyott és kifizetett osztalék egy részvényre jutó értéke. A részvények birtokosai számára a legfontosabb mutatónak tekinthető. Annál vonzóbb egy részvény, minél magasabb a rá jutó, kifizetésre kerülő osztalék, tehát minél magasabb a hányados értéke. A magas hányadossal rendelkező részvények keresettek és a befektetők hajlandóak akár az aktuális árfolyamnál többet is fizetni érte, azaz részvényár-felhajtó hatású lehet a mutató. Ennek analógiáján, az alacsonyabb hányadossal rendelkező részvények piaci árfolyama is alacsonyabb lehet.

$$
\text { Egy részvényre jutó osztalék }=\frac{\text { Kifizetett osztalék }}{\text { Vállalkozás által kibocsátott részvények darabszáma }}
$$

Az osztalékhozam az egy részvényre jutó osztalék mutatót használja fel és méri az adott részvény árfolyamához. A jövőbeni befektetők szemszögéből lehet érdekes mutató, hiszen a mutató számlálójában és nevezőjében szereplő értékek egyaránt a befektető által eszközölt befektetés megtérülésének forrásai (osztalékfizetés, ill. árfolyamnyereség realizálása formájában). Az osztalékhozamra ugyanaz elmondható, mint az egy részvényre jutó osztalék mutatóra, azaz minél magasabb az értéke, annál vonzóbb a befektetők számára és annál többet hajlandóak fizetni érte.

$$
\text { Osztalékhozam }=\frac{\text { Egy részvényre jutó osztalék }}{\text { Részvényárfolyam }}
$$




\section{Forrásjegyzék}

1) Adorján, Cs., Lukács, J., Róth, J., Veit, J. (2003). Számvitel és elemzés II. Budapest: Magyar Könyvvizsgálói Kamara.

2) Béhm, I. (1998). Gazdasági-pénzügyi ismeretek. Budapest: Perfekt Gazdasági Tanácsadó, Oktató és Kiadó Zrt.

3) Bíró, T., Kresalek, P., Pucsek, J., Sztanó, I. (2016). A vállalkozások tevékenységének komplex elemzése. Budapest: Perfekt Gazdasági Tanácsadó, Oktató és Kiadó Zrt.

4) Bíró, T., Pucsek, J., Sztanó, I. (2010). Amit a mérleg mutat 2010. Budapest: Saldo Zrt.

5) Blumné Bán, E., Kresalek, P., Pucsek, J. (2011). A vállalati elemzés alapismeretei. Budapest: Saldo Zrt.

6) Jacobs, O. H., Oestreicher, A. (2000). Mérlegelemzés. Budapest: Kossuth Kiadó.

7) Sebes, J. (2013). Elemzés - Vállalati elemzés - Mérlegelemzés. Budapest: Aura Kiadó.

8) Szóka, K. (2018). Gazdasági elemzés elöadásanyag. Soproni Egyetem Lámfalussy Sándor Közgazdaságtudományi Kar.

9) Zéman, Z., Béhm, I. (2016). A pénzügyi menedzsment controll elemzési eszköztára. Budapest: Akadémiai Kiadó. 


\section{Jövedelmezőség elemzése}

A vállalkozás érintettjei részéről alapvető elvárás, hogy cégünk hatékony technológiát alkalmazzon, eredményesen müködjön, profitot érjen el, azaz eredményes legyen. A kis- és középvállalkozások körében különösen fontos, hogy mekkora ez az eredmény, hiszen egy kis változás is nagy kihatású lehet, de természetesen ez minden cég életében fontos méröszám.

De mit is jelent az eredményesség, hogyan lehet ezt elemezni? Ebben a fejezetben az eredmény, a jövedelmezőség témáját jártjuk körbe, bemutatva az eredmény különböző szintjeit, az elemzési lehetőségeket, és jövedelmezőségi mutatókat.

\subsection{A vállalkozás eredményének képződése és annak szintjei}

Egy vállalkozások eredményességét alapvetően a rendszeres és normál üzletmenet során lezajló értékesítések határozzák meg. Nagyon nem mindegy, hogy milyen volumenben és értékben értékesítenek, ezzel kapcsolatban milyen költségek merülnek fel, melyek lehetnek közvetlen és közvetett költségek (lásd Számviteli beszámolók szerepe és jelentősége fejezet). A jövedelmezőség, mint központi kérdés nagyban befolyásolja a tulajdonosi jövedelmeket az osztalékfizetésen keresztül, az államnak fizetett társasági adót - mint állami bevétel - és a visszaforgatható, adózott eredmény nagyságát, ráadásul mindezeket már rövidtávon. Összességében azt mondhatjuk, hogy egy vállalat akkor eredményes, ha a bevételek meghaladják a ráfordításokat.

Mivel az eredmény elsősorban számviteli kategória, első körben vizsgáljuk számviteli megközelítéssel. A már ismerős eredménykimutatásban láthatjuk az eredmény szintjeit, azaz az eredménykategóriákat.

Az üzemi-üzleti tevékenység eredménye a vállalkozás által rendszeresen, üzletszerủen végzett termelő, szolgáltató és kereskedelmi tevékenységek bevételeinek és kiadásainak (ráfordításainak) a különbsége. Minden olyan tétel ide tartozik, mely az értékesítési tevékenységekhez kapcsolódik, függetlenül attól, hogy belföldi vagy külföldi értékesítésről van szó. Az üzemi (üzleti) tevékenység eredménye összköltséges és forgalmi költséges eljárással kétféleképpen határozható meg, ahogy ezt már említettük. Általánosságban az árbevétel, a saját termeléssel, készlet/anyag/áru-beszerzéssel és munkaerővel kapcsolatos kiadások tartoznak ide, illetve az értékcsökkenés költsége.

Az egyéb bevételek és kiadások szintén ide tartoznak, de van olyan tevékenysége is a vállalatnak, mely a pénzügyi műveleteihez kapcsolódik, éppen ezért megkülönböztetünk pénzügyi eredményt is, mely a pénzügyi müveletek bevételeinek és ráfordításainak különbözeteként határozható meg. Általánosságban az időlegesen vagy tartósan meglévő pénzeszközök kihelyezésével, illetve a külső pénzforrások igénybevételével kapcsolatos gazdasági események eredményhatásait látjuk itt, gondoljunk a kapott vagy fizetett kamatokra, bankköltségre stb. 
A két eredménykategória összevonásával kapjuk az adott időszak realizált eredményét, az adózás előtti eredményt. Minden országban időszakonként változó más és más törvények, jogszabályok alapján határozzák meg azokat az adóalap módosító tételeket, melyek segítségével az adóalap kiszámítható (lásd adóalap növelő és csökkentő tételek), és az érvényes adózási szabályok ismeretben (lásd adómódosító tételek) számítható ki az adó, jelen esetben a társasági adó. Az adózás előtti eredményből levonva a számított társasági (fizetendő) adót, kapjuk meg a „végső” adózott eredményt.

2016 előtt Magyarországon, még ennél a tételnél nem ért véget az eredménykimutatás, volt még egy eredménykategória és két tétel. A Rendkívüli eredmény (bevételek és ráfordítások) megszünt, tételei bekerültek az egyéb tételek közé. Az Eredménytartalék igénybevétele osztalékra, részesedésre, illetve a Jóváhagyott osztalék, részesedés szintén törlésre került, 2016 elött ezekkel a tételekkel együtt határozódott meg a Mérleg szerinti eredmény. Ma már értelemszerüen a Saját tőke elemei között nem a Mérleg szerinti eredménnyel, hanem az Adózott eredménnyel találkozunk. Ebböl következik, hogy az eredmény felosztását, azaz a jóváhagyott, fizetett osztalék nagyságát már nem tudjuk az eredménykimutatásból megállapítani. A gyakorlatban ez azt jelenti, hogy az adózott eredmény osztalékként történő felhasználásáról a tárgyévet követő időszakban megtartott közgyülésen hoznak döntést, így azt (a jóváhagyott osztalékot) a következő időszaki számviteli nyilvántartásokban kell kimutatni.

\section{1. táblázat Az eredménykimutatás felépítése}

\begin{tabular}{|c|c|}
\hline Összköltség eljárással & Forgalmi költség eljárással \\
\hline \multicolumn{2}{|c|}{ ÉRTÉKESÍTÉS NETTÓ ÁRBEVÉTELE } \\
\hline AKTIVÁLT SAJÁT TELJESÍTMÉNYEK & \multirow{4}{*}{$\begin{array}{l}\text { ÉRTÉKESÍTÉS KÖZVETLEN KÖLTSÉ- } \\
\text { GEI } \\
\text { ÉRTÉKESÍTÉS KÖZVETETT KÖLTSÉGEI }\end{array}$} \\
\hline ANYAGJELLEGÜ RÁFORDÍTÁSOK & \\
\hline SZEMÉLYI JELLEGÜ RÁFORDÍTÁSOK & \\
\hline ÉRTÉKCSÖKKENÉSI RÁFORDÍTÁSOK & \\
\hline EGYÉB BEVÉTELEK & EGYÉB BEVÉTELEK \\
\hline EGYÉB RÁFORDÍTÁSOK & EGYÉB RÁFORDÍTÁSOK \\
\hline \multicolumn{2}{|c|}{ ÜZEMI-ÜZLETI TEVÉKENYSÉG EREDMÉNYE } \\
\hline \multicolumn{2}{|c|}{ PÉNZÜGYI MÜVELETEK BEVÉTELEI } \\
\hline \multicolumn{2}{|c|}{ PÉNZÜGYI MÜVELETEK RÁFORDÍTÁSA } \\
\hline \multicolumn{2}{|c|}{ PÉNZÜGYI MÜVELETEK EREDMÉNYE } \\
\hline \multicolumn{2}{|c|}{ ADÓZÁS ELŐTTI EREDMÉNY } \\
\hline \multicolumn{2}{|c|}{ ADÓFIZETÉSI KÖTELEZETTSÉG } \\
\hline ADÓZOTT & REDMÉNY \\
\hline
\end{tabular}

Forrás: saját szerkesztés a Számviteli törvény 2. és 3. számú mellékletei alapján 


\subsection{Forrásbevonás és adómegtakarítás}

A jövedelmezőség kapcsán sok mindenről lehet beszélni, hiszen rengeteg tényező hat az eredményre, még a vállalatok viselkedése is. Anélkül, hogy túlzottan belemennénk a finanszírozás vagy a vállalati pénzügyek területeibe, említsük meg az adópajzs hatást.

Mi is ez? Ha egy vállalkozás hitelt, kölcsönt vesz fel - amit meg is kap - annak egyik pénzügyi következménye, hogy időnként kamatot kell fizetnie az idegen forrás használatáért, az az ára. Ez a fizetendő kamat egy pénzügyi ráfordítás, mely csökkenti az adózás előtti eredményt, és kisebb adóalap után kevesebb társasági adót fizet ez a vállalkozás. Úgy is megfogalmazhatjuk, hogy a fizetett kamat nem képez adóalapot, és ez az adóssághoz kapcsolódó rész adómegtakarítást eredményez, és ezt hívjuk adópajzs hatásnak. Ezek után magasabb adózott eredmény várható, melyből több osztalék fizethető, ez pedig növelheti a részvénytulajdonosok hasznát.

Természetesen nem ilyen egyszerü a kép... Gondoljuk csak végig, mi a helyzet akkor, ha a vállalkozás üzemi eredménye alacsony - esetleg nulla -, akkor miből tudjuk levonni a fizetendö kamatot? Már nincs s miből levonni, hogy pozitívak maradjunk, így az adópajzs hatás nem érvényesíthető. Azaz az adómegtakarítás kihasználása, a társasági adófizetés minimalizálása attól is függ, hogy a vállalkozás kép-e akkora jövedelmet kitermelni, amiből kifizeti a kamatokat. Gál (2014) kutatásai szerint igazolt, hogy a nagyobb jövedelmezőséggel rendelkező vállalatok kevésbé vannak eladósodva, tőkeszerkezetükben alacsonyabb mind a rövid, mind a hosszú lejáratú kötelezettségek aránya. Gál és szerzőtársai (2014) a magyar régiók közötti finanszírozási különbségeket vizsgálva pedig arra a megállapításra jutottak, hogy a fejlettebb területeken átlagosan magasabb tőkeáttétel jellemzi a vállalkozásokat, mint a fejletlenebb területeken. Vizsgálataik alapján arra a megállapításra jutottak, hogy ez a jelenség az eszközök fedezetképességével, a vállalkozások piaci pozíciójával és összességében az adott térség gazdagságával, gazdasági teljesítményével magyarázható. (Gál, Gáspár, Parádi-Dolgos, 2014) Ráadásul minél nagyobb adóalappal rendelkezik egy vállalkozás, annál nagyobb az adópajzs jelentősége, ezért valószínüleg több idegen forrást von be, ez viszont csökkentheti a jövedelmezőséget. A vállalatvezetésnek döntést kell hoznia, hogy meddig megy el a hitelfelvételben, de jelen fejezetben és jegyzetben ebbe a témába nem megyünk bele ennél részletesebben.

\subsection{A fedezeti összeg és az ÁKFN struktúra}

Mielőtt megnéznénk a jövedelmezőségi mutatókat, pár szóban tárgyaljuk meg az eredmény más típusú szintjeit is. Részben a számvitel, a gazdasági-pénzügyi elemzés, részben pedig a controlling területéhez tartoznak az ún. ÁKF és ÁKFN struktúrák.

Nézzük ezeket sorban, az ÁKF struktúra jelölései:

Á: Értékesítés nettó árbevétele

- K: Értékesítés közvetlen költsége (vagy változó költségek)

= F: Fedezeti összeg (bruttó eredmény)

Ezekből gyorsan rájöhetünk, hogy ez tulajdonképpen a forgalmi költség eljárással készített eredménykimutatás eleje, melyből azt látjuk, hogy mekkora eredmény, fedezet marad a közvetlen költségek, a többi tétel és az eredmény (nyereség) fedezésére. 
Tulajdonképpen a fedezeti összeg - vagy röviden fedezet - tulajdonképpen az első eredménykategória az üzemi, üzleti eredmény előtt -, értelemszerűen minél nagyobb, pozitív összegü fedezetet szeretnénk elérni, hiszen ez a termékek, a vállalkozás magasabb jövedelmezőségét mutatja.

Az ÁKF struktúra már végighalad az eredményig, azaz

Á: Értékesítés nettó árbevétele

- K: Értékesítés közvetlen költsége (vagy változó költségek)

= F: Fedezeti összeg (bruttó eredmény)

- K: Értékesítés közvetett költsége (vagy fix költségek)

= N: Nyereség (ez körülbelül az EBIT-nek felel meg, lásd még később)

Ez a nyereség nem foglalkozik a számvitelben értelmezett egyéb bevételekkel és egyéb ráfordításokkal, ezért nem írhatjuk azt, hogy az „N”, tehát a nyereség az üzemi, üzleti tevékenység eredménye.

Az alábbi ábrán látható, hogy az F-el jelölt fedezeti pontban a vállalkozásnak nincs nyeresége mivel az összes költség (Kö) megegyezik az árbevétellel (Á). A volumen tengelyre levetített mennyiség az a mennyiség (volumen), melyet tudni kell előállítani és értékesíteni ahhoz, hogy ezt a fedezeti pontot (F) elérjük. Ha ennél többet értékesítünk a vállalkozás nyereséges, ha kevesebbet, akkor pedig veszteséges lesz. Ennek a nyereségnek, veszteségnek a mértékét ki tudjuk számítani, a két egyenes (összes költség, árbevétel) különbözetéből, melyet a 6.1. ábra is jelez, egy-egy pontban, példaként.

(Jelölések: Á: árbevétel, Kv: változó költség, Ká: állandó, fix költség, Kö: összes költség, F: fedezeti pont)

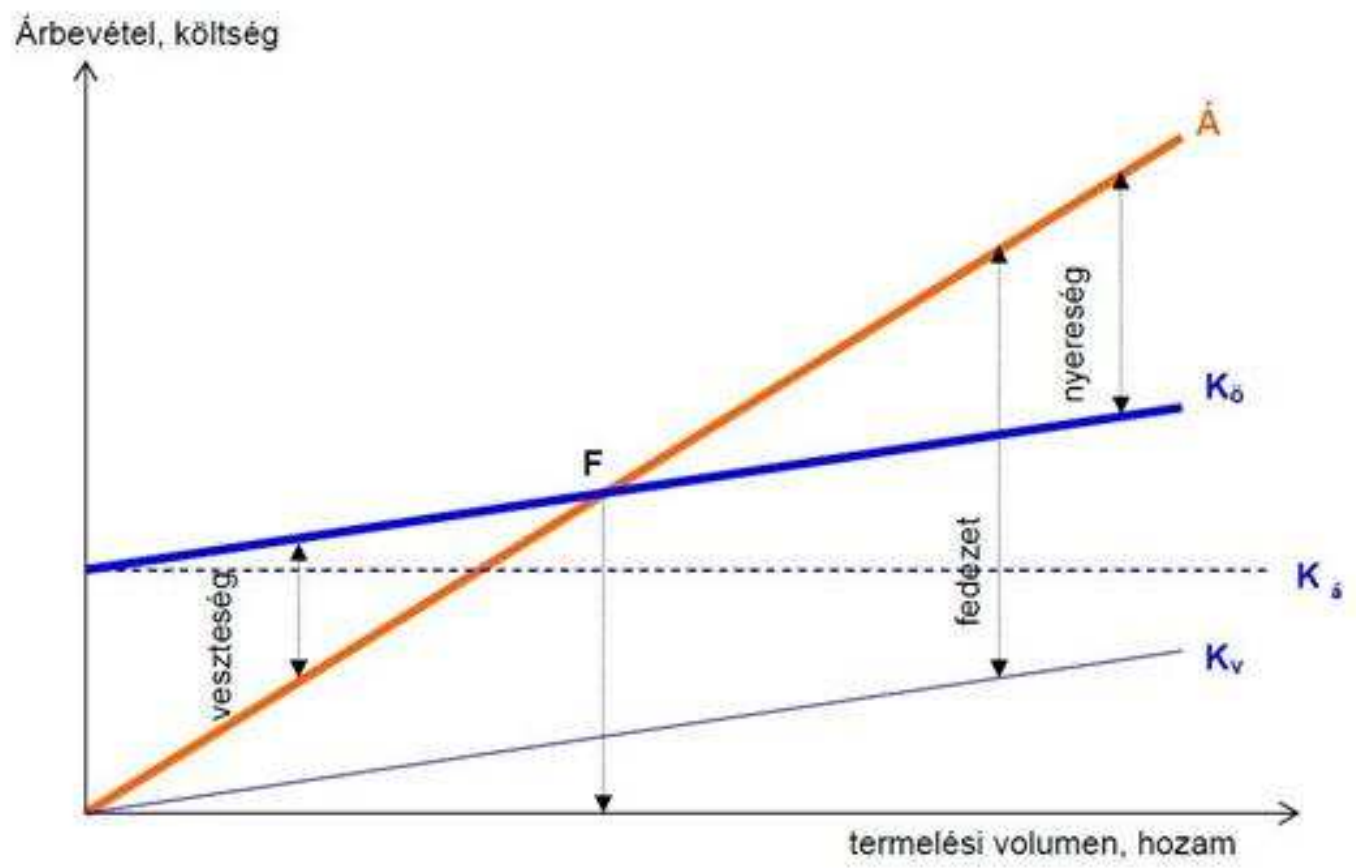

6.1. ábra Az egyszerüsített ÁKFN-struktúra

Forrás: Kovács, 2011 
A fedezeti összeget egyenlettek, képlettel is kiszámolhatjuk:

$=\sum q^{*} p-\sum q^{*} \ddot{o}$, ahol 'q' a mennyiség, a 'p' az egységár, az 'ö' pedig a közvetlen egységköltség A fedezeti pont pedig az a mennyiség, volumen, ahol ezzel a fedezeti összeggel fedezzük az állandó, fix költségeket, azaz

$$
\frac{\text { Ká }}{p-\ddot{o}}
$$

Ennek a fedezetszámításnak ${ }^{2}$ az egyik nagy haszna, hogy kapcsolatot teremt az árbevétel és a változó költségek között, így elmondhatjuk, hogy a fedezet a jövedelmezőség egyik meghatározója, egyfajta mérőskála, minél nagyobb a fedezet, annál magasabb a jövedelmezőség (Ladó, 1999. pp. 59.).

Nézzük meg, hogy ez a vállalkozási, teljesítmény szemléletü fedezet hogyan kapcsolódik a számviteli kategóriákhoz. Szerencsére viszonylag egyszerüen, mivel ha a fedezeti összeghez hozzáadjuk a - számviteli - egyéb bevételeket és levonjuk az egyéb ráfordításokat, akkor már meg is kapjuk az üzemi-üzleti tevékenység eredményét. (Az EBIT, EBITDA, NOPLAT eredményekről később lesz majd szó.)

Ez a típusú fedezetszámítás elég egyszerü, ez egy előny, de ennek hátrányai, korlátai is vannak. Az egyik az, hogy a való életben nincs egyenes arányú kapcsolat a volument és az árbevétel, illetve a közvetlen (változó) költségek között. Gondoljunk csak arra, hogy egyre több és több terméket csak olcsóbban tudunk eladni, azaz kisebb lesz az árbevétel, de gondolhatunk arra is, hogy nagy mennyiségü alapanyagot, alkatrészt kedvezményesebb áron is be tudunk szerezni. A másik ilyen jellegü korlát, hogy valójában hosszú távon nincsenek fix költségek. Ami fix lehet 1-2 hónapig, pl. egy bérleti vagy biztosítási díj, vagy akár az értékcsökkenés, az hosszabb távon már változhat, sőt változni is fog. Kialkudhatunk kedvezőbb szerződéseket, eszközbeszerzés történik stb. Korábbi fejezetben már szó volt róla, hogy iskolai példákban igen, de a gyakorlatban nem is olyan egyszerü eldönteni egy költségtételről, hogy az fix vagy változó költség, illetve milyen mértékben tekinthető változónak, illetve a fedezet számításakor nem vesszük figyelembe a befejezetlen termelést és az elfekvő, immobil készletet, pedig jelentős költségtényezők minden vállalkozás esetében. Végezetül a menedzsment által meghozott döntések, a piac, a kereslet állandó változásai, például a termékösszetételre vonatkozóan állandóan befolyásolják a fedezet, a fedezeti pont összegét, illetve helyzetét.

\subsection{Az eredményesség vizsgálata és a jövedelmezőségi mutatók}

Az eredményesség vizsgálatával tehát azt tudjuk megnézni, megmérni, hogy mekkora az eredmény, illetve nyereségtartalma a tevékenységnek, egy vállalkozásnak. Kifejezi a vállalkozás

\footnotetext{
${ }^{2}$ A fedezetszámításnak több fajtája is van, például a részletesebb, többszintủ, ennek tárgyalása a vezetői számvitel, illetve a controlling témakörébe tartozik, a jegyzet nem foglalkozik vele részletesebben.
} 
eredménytermelő képességét, egyfajta eredményt hasonlít egy kiválasztott viszonyítási alaphoz. Nézzük az alapképletet:

$$
\text { Jövedelmezőség }(\%)=\frac{\text { Eredmény }}{\text { Vetítési alap }}
$$

Az eredményesség vizsgálatával egy minősítő jellegü elemzést tudunk elvégezni, minősíthetjük a tevékenység, a vállalkozás sikerességét, akár más vállalkozásokhoz képest, akár az előző időszakhoz képest. Tulajdonképpen összehasonlíthatóságot teremt más tevékenysége, vállalkozások, ágazatok adataival. Arra természetesen figyelni kell, hogy mindig figyeljünk a tervadatokkal való összehasonlíthatóságra, illetve nézzük meg a korábbi időszakok adatait, azaz trend-, tendenciaelemzést is kell végezni, egy jövedelmezőségi százalék önmagában semmit sem jelent, csak valamivel összehasonlítva, valamihez viszonyítva. Az összehasonlítások során figyelemmel kell lennünk arra is, hogy csak az azonos ágazatban, iparágban tevékenykedő vállalkozásokat hasonlítsuk össze egymással.

Az elemzéshez igazából minden elérhető adatra szükségünk lesz, mérleg, eredménykimutatás, kiegészítő adatok mind szükségesek. Nagyon sok mutató számolható, a vállalat döntése alapján a fontosabbak kerülnek kiértékelésre és bemutatásra a kiegészítő mellékletben, vagy az Üzleti jelentésben.

Induljunk el az általános képlet alapján, elöször nézzük meg, mi kerülhet a számlálóba, azaz melyek a figyelembe vehető eredménykategóriák:

Értékesítés bruttó eredménye (fedezeti összeg, FÖ), üzemi-üzleti tevékenység eredménye (ÜÜTE), adózás előtti eredmény (AEE), adózott eredmény (AE), EBIT, EBITDA, NOPLAT.

Talán az utóbbi három eredménykategória kevésbé lehet ismert, nézzük meg ezek kiszámítási módjait:

- $\quad$ EBIT (Earnings before Interest and Taxes) $=$ AEE + Fizetett kamatok

- EBITDA (Earnings before Interest, Taxes, Depreciation and Amortisation) $=$ AEE + Fizetett kamatok + ÉCS

- $\quad$ NOPLAT (Net Operating Profit less adjusted Taxes) $=$ AE + Fizetett kamatok

Ezek kivétel nélkül mind nemzetközileg híres és elterjedt eredménykategóriák. Az EBIT nagyjából az operatív tevékenység eredményességét mutatja meg a finanszírozás - kamatfizetés torzító hatása nélkül, az EBITDA ugyanezt cash flow szemléletben közelíti meg, a levont tehát eredményt rontó - értékcsökkenés összegét vissza(hozzá)adja, mondván, azt valójában nem fizette ki a vállalkozás senkinek. A NOPLAT pedig az EBIT logikájából indul ki, viszont figyelembe veszi az adófizetés tényét, összegét, mint minden országban meglévő gazdasági tényezőt. 
Most jöjjenek felsorolásszerüen az alkalmazható vetítési alapok, azaz nézzük, mit kerülhet a nevezőbe: ÉNÁ, ÉNÁ és további bevételek, ST, lekötött eszközök, összes eszközérték, bérköltség, személyi jellegü ráfordítások, létszám, stb. Ezen számlálókat és nevezőket kell „öszszepárosítani”, természetesen nem random, hanem adott közgazdasági logika mentén.

\subsection{1. Átlagos fedezeti hányad (Bruttó jövedelmezőség, Return on Sales (ROS))}

A fedezeti hányad azt mutatja meg, hogy az árbevétel mekkora része, hány százaléka lesz fedezet, ilyenkor a már ismerős fedezeti összeget az árbevételhez viszonyítjuk. Képzeljünk el egy tortát, ami az árbevételt képviseli és annak egy szelete (százaléka) lesz a fedezet, azaz látjuk, hogy az árbevétel mekkora része maradt a ,zsebünkben”, mint nyereség, mint fedezet. Ennek a fedezetnek ,van dolga”, fedeznie kell a közvetett költségeket, fedezetet kell nyújtania az egyéb és pénzügyi müveletek eredményére és természetesen nyereséget is kell(ene) tartalmaznia, hiszen ne felejtsük, a nyereséges müködés a cél!

$$
\text { Átlagos fedezeti hányad (\%) }=\frac{\text { ÉNÁ - Értékesítés közvetlen költsége }}{\text { ÉNÁ }}
$$

Számolhatjuk a mutatót az egész vállalkozásra vetítve, de számolhatjuk csak egy-egy termékre, tevékenységre is, ilyenkor annak a terméknek vagy résztevékenységnek a jövedelmezöségét mutatja meg.

Ami fontos, hogy a mutató értelmezése csak az adott vállalkozáson belül jelentős, mivel ugye a fedezeti összeghez - ami a számláló - a közvetlen költségekre van szükség és ennek meghatározása, azaz hogy mi számít közvetlennek, az adott vállalkozás belügye, ők döntik el. A controller, a gazdasági vezető mondja meg, mi közvetlen, és mi közvetett költség. Ha a mutató alacsony, akkor sajnos arra lehet következtetni, hogy túl sok a közvetlen költség, az árbevétel jelentős részét elviszik az alapanyag, alkatrész, technológiai bér, stb. költségek és nem lesz túl sok a nyereség. Mint minden jövedelmezőségi mutatónál, itt is a „minél nagyobb, annál jobb” a mérőszám, nyereségesebb működés esetén magasabb mutatót látunk.

\subsection{2. Árbevétel-arányos jövedelmezőségi mutatók}

Ez a mutatócsoport megmutatja, hogy az árbevétel (bevétel) mekkora része vált eredménnyé, azaz nyereséggé. Több mutató is számolható annak függvényében, hogy minek nyereségtartalmát vizsgáljuk.

$$
\begin{gathered}
\frac{\text { Üzemi - üzleti tevékenység eredménye }}{\text { ÉNÁ }+ \text { Egyéb bevételek }} \\
\frac{\text { Adózás előtti eredmény }}{\text { ÉNÁ }+ \text { Egyéb bevételek + Pénzügyi műveletek bevétele }}
\end{gathered}
$$




\section{Adózott eredmény \\ ÉNÁ + Egyéb bevételek + Pénzügyi műveletek bevétele}

Itt is elképzelhetünk egy tortát, ami az árbevételt (bevételt) reprezentálja, és az adott jövedelmezőségi érték megmutatja, hogy annak mekkora része lett nyereség. Természetesen itt is igaz a minél nagyobb, annál jobb értékelési elv, a helyes összehasonlítás megválasztása, illetve, hogy a trendek, tendenciák vizsgálata fontos.

Amire még nagyon figyelni kell a számítások során, hogy nézzük meg alaposan, minek a jövedelmezőségéről van szó, mivel annak megfelelően kell megválasztani a nevezőt is. Azaz a számláló bővítésével, bővíteni kell a nevezőt is, az eredménykimutatásnak megfelelően. Például amikor az adózás előtti eredmény van a számlálóban, azért kell beletenni a nevezőbe már a pénzügyi müveletek bevételét is, mert az is bevétel, és azt tartalmazza az adózás előtti eredmény, nem szabad kihagyni.

\subsubsection{Tőkearányos jövedelmezőség}

Ez a mutatócsoport azt vizsgálja, hogy a vállalkozás a saját tőke egységével mekkora jövedelmet, eredményt ért el a vizsgált időszakban. Nem mindegy, hogy a befektetett „1Ft” tőkével mekkora nyereséget ér el vállalkozásunk. Ennek alakulása elsősorban a tulajdonosok, befektetők érdeklődésére tarthat számot, illetve összehasonlíthatóvá teszi a cégeket a nemzetközi gyakorlatban.

$$
\frac{\text { Üzemi - üzleti tevékenység eredménye }}{\text { Saját tőke }}
$$

\section{Adózás előtti eredmény}

Saját tőke

Ebben a csoportban már „híresebb”, azaz elnevezett mutatót is találunk, ez a ROE (Return on Equity), azaz a Saját tőke egységére vetített jövedelmezőség. Ez a mutató a tőkemegtérülést és a menedzseri érdekeltséget egyszerre mutatja, egyben utal az osztalékfizetésre, mivel az adózott eredményből - és az eredménytartalékból, meghatározott szabályok alapján - lehet osztalékot fizetni, és a menedzsment munkáját sokszor a szerint ítéli meg a befektetői kör, hogy ez mennyi.

$$
\text { Return on Equity }(\mathrm{ROE})(\%)=\frac{\text { Adózott eredmény }}{\text { Saját tőke }{ }^{3}}
$$

Itt behozhatjuk a már megismert, új eredménykategóriákat is, mivel ezen adatok ismeretében is számítható a befektetett saját tőke eredményessége.

\footnotetext{
${ }^{3}$ Ha a maximális osztalékfizetési képességet szeretnénk vizsgálni, akkor a saját tőke helyett a jegyzett tőke szerepeltessük a nevezőben.
} 
Tőkearányos korrigált AEE jövedelmezősége $(\%)=\frac{\text { EBIT }}{\text { Saját tőke }}$

Tőkearányos korrigált ÉCS nélküli eredmény (\%) $=\frac{\text { EBITDA }}{\text { Saját tőke }}$

Befektetett tőke hozama (Return on Invested Capital, ROIC)(\%) $=\frac{\text { NOPLAT }}{\text { Működésbe fektetett tőke }}$

Itt egy kis magyarázattal tartozunk, a működésbe fektetett tőke nem más, mint a Saját tőke + kamatköteles kötelezettségek (hitelek, kölcsönök, kötvénytartozások), mivel ezeket a tételeket, összegeket valóban a működésbe forgatjuk, annak okán vetünk fel hitelt, bocsájtottunk ki kötvényt, stb.

Mivel a nevezőben sokszor a saját tőke szerepel és az ugye egy statikus mérlegadat, figyelemmel kell lennünk az év végi tőkekorrekciókra és azokat konzekvensen kell kezelnünk. Gondoljunk csak bele, egy év végi tőkeemelés esetén nagyobb lesz a nevező - nő a saját tőke - azaz kisebb lesz az eredményesség, ami rossz hír, de a tökeemelés ezzel ellentétben pedig a cégbe fektetett bizalom jele, pont, hogy pozitívként értékelendő. A saját tőke összegében jelentős módosító tényező még - többek között - az értékelési tartalék, így lehet, hogy célszerü azt figyelmen kívül hagyni, ha az nagyon megváltozik. Mindig az adott helyzetnek megfelelően értékeljünk és döntsünk.

Mint mindegyik jövedelmezőség esetében most is igaz a minél nagyobb, annál jobb értékelési elv, a helyes összehasonlítás megválasztása, illetve, hogy a trendek, tendenciák vizsgálata fontos.

\subsubsection{Bér, élőmunka-arányos jövedelmezőség}

Mivel az élőmunka, és annak költsége szinte minden vállalkozás életében meghatározó jelentőségü, ezért érdemes foglalkozni ezen mutatókkal is. Ezen mutatók az 1 före, ill. az 1 Ft bérköltségre jutó eredményt mutatják, nagyon hasonló számítási módszerrel, az adott eredményt el kell osztani a létszámmal és/vagy a bérköltséggel, amire éppen kíváncsiak vagyunk.

\section{Eredménykategória \\ Létszám (fő) \\ Eredménykategória \\ Bérköltség}

Az eredménykategória helyére azt írjuk, ami éppen releváns. Első esetben Ft/fő lesz a mértékegység, tehát az egy főre jutó nyereséget kapjuk meg, a második mutató esetében pedig újra \% lesz a mértékegység, azaz megmutatja, hogy a bérköltséghez képest mekkora lett az adott nyereség. Tágabb értelmezésben a bérköltség helyett a személyi jellegü ráfordítás is lehet a neve- 
zőben, ez pontosabb, hiszen ez az összes, emberi erőforrással kapcsolatos költségeinket tartalmazza, de természetesen ilyenkor mindig kisebb, azaz rosszabb lesz a mutató a nagyobb nevező miatt.

Ahogy már említettük, ebben a mutatócsoportban is igaz a minél nagyobb, annál jobb értékelési elv, a helyes összehasonlítás megválasztása, illetve, hogy a trendek, tendenciák vizsgálata fontos.

\subsubsection{Eszközarányos jövedelmezőség}

Ahogy a neve is mutatja e mutatócsoport az eszközök jövedelemtermelő képességére utal. A kiszámítás nagyon egyszerü, a releváns eredményt el kell osztani az eszközök értékével.

$$
\frac{\text { Eredménykategória }}{\text { Adott eszközcsoport vagy Összes eszköz }}
$$

A jól ismert eredménykategóriákat eloszthatjuk egy kiválasztott eszközcsoporttal, a lekötött eszközökkel, vagy akár az összes eszközzel (lásd mérlegföösszeg) is.

A lekötött eszközök csoportja, azok az eszközök, melyek leginkább „oda vannak kötve” a tevékenységhez, csak arra használhatóak, amire valók, ill. ez az eszközcsoport minden cégnél megtalálható.

Lekötött eszközök $=$ Immateriális javak nettó értéke + Tárgyi eszközök nettó értéke + Készletek

A fejezet eddig részénél is már jól látható, hogy valóban sok jövedelmezőségi mutató számolható, melyeket, mint lehetőségeket meg is mutatunk. Fontos azonban, hogy tudjuk, a viszonyítási alapként olyan eszközöket, eszközcsoportot válasszunk, melyek az eredménykategóriához, annak létrejöttéhez valóban hozzájárultak, ezek például:

$$
\begin{gathered}
\frac{\text { Üzemi - üzleti tevékenység eredménye }}{\text { Immateriális javak + Tárgyi eszközök }} \\
\frac{\text { Üzemi - üzleti tevékenység eredménye }}{\text { Készletek }} \\
\frac{\text { Üzemi - üzleti tevékenység eredménye }}{\text { Immateriális javak + Tárgyi eszközök + Készletek }} \\
\frac{\text { Adózás előtti eredmény }}{\text { Befektetett eszközök + Készletek }}
\end{gathered}
$$


Mindettől függetlenül vannak „híres”, elnevezett eszközarányos jövedelmezőségi mutatók, melyeket az egész világon ismernek és számolnak, nézzük meg ezeket.

$$
\text { Eszközarányos nyereség (Return on Net Assets, ROA) (\%) }=\frac{\text { Adózás előtti eredmény }}{\text { Összes eszköz }}
$$

$$
\text { Eszközmegtérülési mutató (Return on Investment, ROE) (\%) }=\frac{\text { Adózott eredmény }}{\text { Összes eszköz }}
$$

Utóbbi esetben az összes eszköz helyett értelmezhető a befektetett eszköz vagy a müködésbe befektetett töke is.

Kereskedelmi vállalkozások esetében pedig a készleteket veszik alapul, ezen eszközök megtérülésére kíváncsiak elsősorban a befektetők.

\section{Eredménykategória \\ Készletek}

Természetesen mindegyik mutatóra igaz a minél nagyobb, annál jobb értékelési elv, a helyes összehasonlítás megválasztása, illetve, hogy a trendek, tendenciák vizsgálata fontos. Ami jelen esetben még bonyolítja a helyzetet, hogy a mérlegben ki nem mutatott, bérelt eszközök is javítják a jövedelmezőséget, pedig nem szerepel a nevezőben, ilyen esetben alkalmazhatunk adatkorrekciót.

\subsubsection{Erőforrás-arányos (komplex) jövedelmezőség}

Ebben a mutatócsoportban az összes jellemző erőforrás helyet kap, azaz egy komplex jövedelmezőséget látunk, hiszen a lekötött eszközökre és a bérköltségre jutó nyereséget tudjuk kiszámolni és értékelni. A mutatók létjogosultsága, hogy tárgyi eszköz, immateriális jószág, készlet, humán erőforrás minden cégnél van, így fontos, hogy ezek nyereségtermelő képességét is megvizsgáljuk.

\section{Eredménykategória \\ Lekötött eszközök és Bérköltség}

Ebben az esetben se felejtsük el, hogy itt is igaz a minél nagyobb, annál jobb értékelési elv, a helyes összehasonlítás megválasztása, illetve, hogy a trendek, tendenciák vizsgálata fontos.

Az eddigiekből bebizonyosodott, hogy nagyon sok jövedelmezőségi mutató értelmezhető és számolható, sok eredménykategória létezik, a vetítési alapok száma is jelentős. A „,mindent el lehet osztani mindennel" elv alapján matematikailag valóban rengeteg mutató képezhető, de azt tudnunk kell, hogy a vállalkozások nem számolják ki, és föleg nem értelmezik az összeset. Minden cég, minden vállalkozás azt a pár jövedelmezőségi mutatót számolja és elemzi, mely számára valóban gyakorlati haszonnal jár, és persze, melyeket a tulajdonosok is igénylik. Ezen 
mutatók köre természetesen nagyban függ az iparágtól is, hiszen más mutatókat vizsgál egy kereskedelmi cég, egy termelő cég vagy éppen egy mezőgazdasági vállalkozás. Tekintettel kell lenni arra is, hogy ha statikus és dinamikus adatok keverednek egy jövedelmezőségi mutatóban az nem annyira szerencsés (pl. eszközmegtérülési mutatók), ezért ott a mérlegadatok helyett átlagadattal célszerü számolni, használjunk pl. negyedéves kronologikus átlagot.

\subsubsection{Tőzsdei társaságok jövedelmezőségének elemzése}

Anélkül, hogy túlzottan belemennénk a részletekbe, megemlítünk pár olyan mutatót, melyet tőzsdén szereplő társaságok esetében célszerü kiszámolni és értékelni.

Az egyik ilyen mutató az EPS mutató, mely a cég adózott eredményét a részvények számához viszonyítja. Ez a tőzsdei megítélés fontos mérőszáma, természetesen arra figyelni kell, hogy a nevezőben olyan részvényszám szerepeljen, melyek után a társaság valóban fizet osztalékot, azaz figyelmen kívül kell hagyni pl. a szavazatelsőbbségi részvények számát.

Egy részvényre jutó nyereség (earnings per share, EPS) $=\frac{\text { Adózott eredmény }}{\text { Összes részvény száma }}$

Szintén értékes piaci jellegü mutató a $\mathrm{P} / \mathrm{E}$ ráta, mely az értékpapírok árfolyamát az - előbb kiszámolt - egy részvényre jutó nyereséghez viszonyítja. A mutató azt fejezi ki, hogy a tulajdonosoknak mennyit kell fizetni egy forintnyi (dollárnyi, eurónyi, stb.) nyereségfért. Ha a cég $\mathrm{P} / \mathrm{E}$ mutatója a piaci átlag felett szerepel, akkor a társaság felülértékelt, ha alatta, akkor alulértékelt.

$$
\frac{\text { Árfolyam }}{\text { Nyereség }} \text { arány }\left(\frac{\text { Price }}{\text { Earnings }}, \frac{\mathrm{P}}{\mathrm{E}}\right)=\frac{\text { Részvény árfolyama }}{\text { Egy részvényre jutó adózott nyereség (EPS) }}
$$

Amit még érdemes kiszámolni az az osztalékhozam, ami az előzőkkel szemben a tőzsdei befektetés tényleges hozamát vizsgálja. A tényleges hozamot a befektetés jelenlegi értékével vetjük össze, ez a mutató a rövid távú befektetők számára hasznosabb, mivel döntéseiket inkább e mutató, érték alapján hozzák meg. (A távlati, inkább hosszú távban gondolkodó befektetők inkább az EPS és P/E mutatókat vizsgálják meg alaposan.)

$$
\text { Osztalékhozam }=\frac{\text { Egy részvényre jutó osztalék }}{\text { Részvény árfolyama }}
$$

A tőzsdei cégek esetében számolt mutatók esetén is igaz, hogy minél nagyobb, annál jobb, ám ennél pontosabb értékelési szempontot csak a részletes és komplex tőzsdei cégértékelés ad. 


\subsection{A mutatók rendszerbe foglalása - a Du Pont rendszer}

A mutatók között összefüggéseket fedezhetünk fel, az egyik változása hat a másikra és fordítva, néha több tényező is kihat egy - közös - mutatóra. Ezekre az összefüggésekre a cégek már korábban is rájöttek, illetve a befektetők tudni szeretnék, hogy egy-egy csúcsmutató (pl. ROA, ROE, ROI) változása mögött milyen tényezők, milyen további mutatók - azok hatásai - vannak.

Az egyik ilyen legelterjedtebb rendszer a Du Pont mutatószámrendszer. A DuPont francia kémiaipari vállalat a saját jövedelmezőségének értékelése végett kifejlesztett egy módszert, ami azután az egész világon elterjedt. Nagyon röviden, a módszer lényege, hogy az értékesítés nettó árbevételének közbeiktatásával és a standardizálás segítségével felbontja az adott jövedelmezőségi mutatót két részmutatóra, minek a segítségével jobban értékelhető az eredetileg vizsgált mutató.

Az eredeti Du Pont mutatószámrendszer középpontjában a más megismert befektetett tőke megtérülése (Return on Investment) mutató áll, mivel ez egy olyan összevont, csúcsmutató, melynek részei önmagukban is fontos jelentéssel bírnak. Ez a mutató felbontható az árbevétel arányos eredmény és az eszközök forgási sebességének a szorzatára, és természetesen e két mutató tovább is részletezhető. A mutató előnye a részletes adatok megszerzése, az összehasonlítás lehetőségének megszerzése, ám hátránya, hogy - mivel csúcsmutatókról van szó - nem tudjuk, hogy a mutató mely része és miért módosult, illetve felerősödhetnek a rövidtávú nyereségmaximalizálási törekvések.

Természetesen nem csak ez az egy mutató vizsgálható ezzel a módszerrel, szinte az összes jövedelmezőségi mutató felbontható eképpen.

Nézzük meg egy példán keresztuil a rendszer müködését! Legyen a kiválasztott mutató a ROE mutató, mely a tőkemegtérülést mutatja, az adózott eredmény és a saját tőke hányadosa.

$$
\text { Return on Equity }(\mathrm{ROE})(\%)=\frac{\text { Adózott eredmény }}{\text { Saját tőke }}
$$

Első lépésként kiszámoljuk a mutató bázis és tárgyidőszaki adatát, majd megnézzük, hogy milyen mértékben változott egyik időszakról a másikra, azaz mennyivel nőtt vagy csökkent. Ezt a különbséget fogjuk vizsgálni, ennek a változásnak az okaira vagyunk kíváncsiak.

Következő lépésben ezt a mutatót az értékesítés nettó árbevételének a segítségével felbontjuk két mutatóra, az egyik egy árbevétel-arányos jövedelmezőségi mutató lesz, a másik egy forgási sebesség. (Attól függ, hogy minek a forgási sebessége, hogy mi szerepel az eredeti mutató nevezőjében.)

$$
\text { Árbevételarányos jövedelemzőség (\%) }=\frac{\text { Adózott eredmény }}{\text { ÉNÁ }^{4}}
$$

\footnotetext{
${ }^{4}$ A 6.4.2-es alfejezetben megtárgyaltuk, hogy az eredménykimutatáshoz igazítva, helyesen a mutató nevezőjében az ÉNÁ + Egyéb bevétel szerepel, ám a mutató felbontásnál ettől a szabálytól eltekintünk.
} 


$$
\text { Saját tőke forgási sebessége }=\frac{\text { ÉNÁ }}{\text { Saját tőke }}
$$

Ha ezt a két mutatót összeszorozzuk, akkor az ÉNÁ kiesik, és visszakapjuk az eredeti ROE mutatót, ebből is látszik, hogy a felbontás matematikailag is igazolt és megvalósítható.

Következő lépésben mindkét mutatónak kiszámoljuk a bázis és tárgy időszaki értékét, majd képezzük a fiktív - eredeti - tőkearányos jövedelmezöséget úgy, hogy összeszorozzuk a bázis árbevételarányos jövedelmezőségi adatot a tárgy időszaki saját tőke forgási sebességgel. (Mindig maradjunk ennél a sorrendnél!)

Utána következik a standardizálás, ennek megfelelően:

Saját tőke forgási sebességének változásának hatása a tőkearányos jövedelmezőségre:

$$
\text { = Fiktív jövedelmezőség }- \text { Bázis (eredeti) jövedelmezőség }
$$

és az Árbevétel-arányos jövedelmezőség változásának hatása a tőkearányos jövedelmezőségre:

$$
\text { = Tárgy (eredeti) jövedelmezőség }- \text { Fiktív jövedelmezőség }
$$

E két hatás alapján fogjuk látni, hogy az eredeti ROE mutatóra hogyan, milyen hatást gyakorolt e két tényező. Ha mindent jól számoltunk, akkor a két hatás előjelhelyes összege megegyezik az eredetileg számolt változással (hiszen azt bontottuk fel).

A DuPont módszerhez hasonlóan építhetők fel más rátapiramisok is (RL, ZVEI, stb.), nézzünk egy példát a ROE mutató másik felbontására:

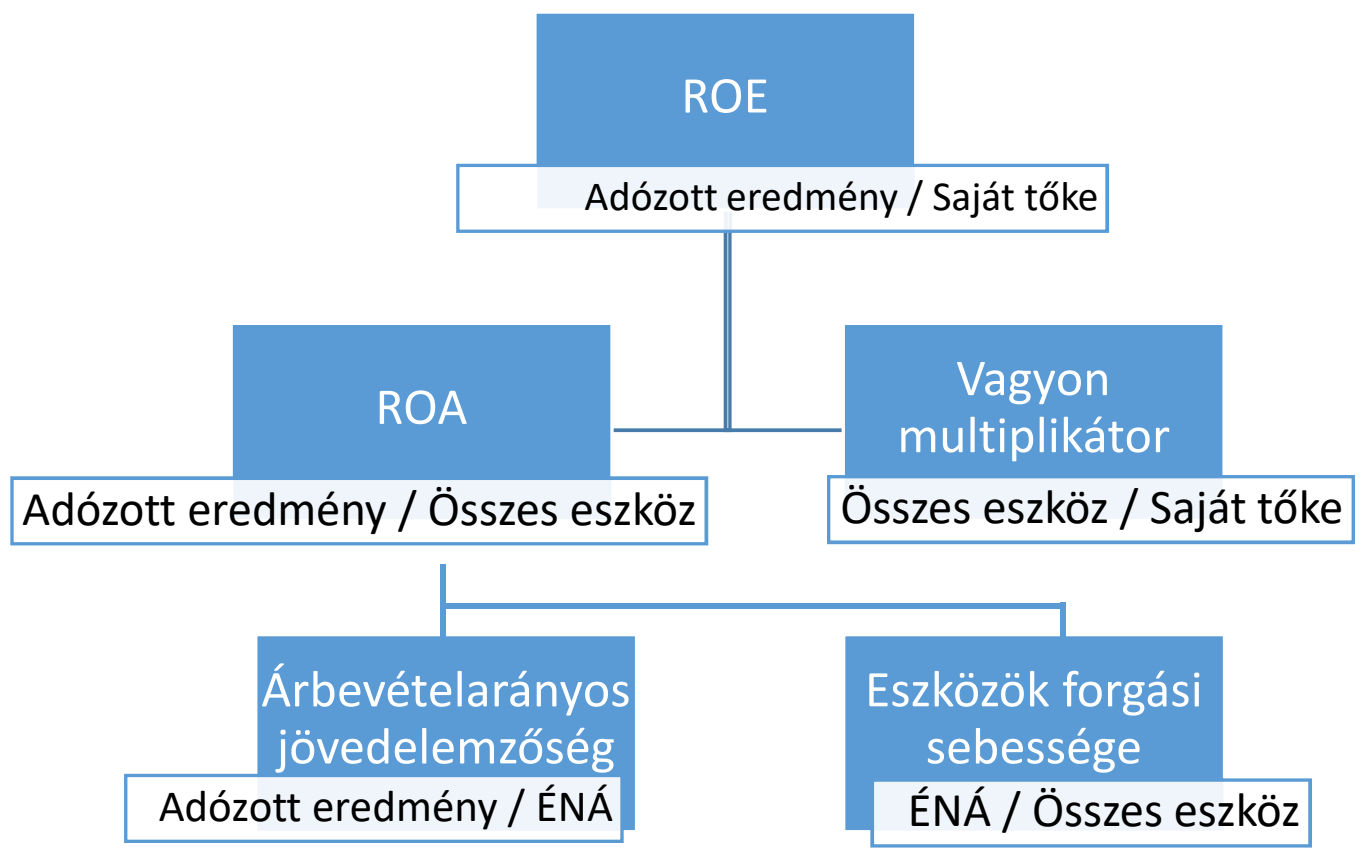

6.2. ábra Ráta-piramis (ROE)

Forrás: saját szerkesztés 
Ezekkel a felbontásokkal a mutatókra ható gyakorló mutatókra, tényezőkre tudunk rávilágítani.

A lényeg mindig az, hogy számszakilag, logikailag és számvitelileg is korrekt, valós kapcsolatokat mutassunk ki, illetve a szükséges adatokat meg kell szerezni az alapos elemzéshez.

\subsection{Kereskedelmi vállalkozások eredményelemzése}

A kereskedelmi vállalkozások esetében az elemzés középpontjában az árrés (a haszon), és költségek elemzése áll. Emiatt az elemzés menete egy kicsit eltérő az eddig megszokottól:

ÉNÁ

- ELÁBÉ

=Kereskedelmi árrés

- Értékesítés közvetlen költségei

$=$ Értékesítés fedezeti összege

- Közvetett költségek

\pm Egyéb bevételek, ráfordítások egyenlege

= Üzemi (üzleti) eredmény

Ejtsünk pár szót az árrésről, illetve a haszonkulcsról. Az árrés nem más, mint az értékesítés nettó átbevételének és az eladott áruk beszerzési értékének a különbsége, ekkora tömegü árrést, hasznot ért el a vállalkozás az adott időszakban. A cél ennek az eredményként is felfogható árrésnek a növelése, ami nem meglepő, hiszen alapvető kereskedelmi cél, hogy drágábban adja el az árukat, mint ahogy beszerezte. Ennek az árréstömegnek egyfajta fedezeti funkciója van, feladata, hogy fedezetet biztosítson a költségekre és a nyereségre is. Az árrésre számos tényező gyakorol hatást, például maga az árbevétel nagysága, hiszen minél magasabb az árbevétel annál több lesz az árrés. Szintén ilyen tényező az áruforgalom összetétele, nem mindegy, hogy mekkora árrésủ áruból adunk el többet, szeretnénk a magasabb árrésszintü termékek eladását növelni, illetve fontosak még az árintézkedések (értékesítési irány, árdifferenciálás, árpolitika, beszerzési források) helyes megválasztása is.

A hétköznapi életben sokszor összekeverjük az árrés és a haszon kifejezéseket, azonban ezt meg kell különböztetni, nézzük a számítást:

Árrésszint (\%) = Árréstömeg / Árbevétel, ami megmutatja, hány százalék az egységnyi árbevételre jutó árréstömeg.

Haszonkulcs (\%) = Árréstömeg / ELÁBÉ, ami megmutatja, hogy az adott áru beszerzési árát hány \%-os többlettel terheli meg a vállalkozás az értékesítés során.

A fedezeti pontot egyfajta minimálisan elérendő értékesítési forgalomként foghatjuk fel, azaz mekkora az az árbevétel, mely az összes költséget fedezi. 
Képlete:

$$
\frac{\text { Állandó költségek összege }}{\text { Árrés a forgalom százalékába - Változó költségek a forgalom százalékában }}
$$

Ha ezt a megcélzott forgalmat el tudjuk érni, akkor minden költség fedezve lesz, a cél természetesen mindig az e feletti forgalom elérése!

Külkereskedelmi vállalkozás eredményének elemzésekor figyelemmel kell arra, hogy ha saját számlás külkereskedelmi tevékenységet végez, akkor a megkapott árbevételböl le kell vonni az esetleges engedményeket és a devizában fizetett fuvarköltséget, illetve, ha bizományi formában végzi a külkereskedelmi tevékenységet, akkor a bevétele a bizományosi díj plusz a limitár-eredmény. (Limitár-eredmény: ha a megbízó által meghatározott limitár feletti eladási árat tudok elérni, a különbség az vállalkozásé.)

\subsection{A vállalkozási eredmény elemzése}

Ahogy már említettük, a sikeres müködés alapkövetelménye a jövedelmező gazdálkodás (kivéve nonprofit szervezetek esetében), mely a vállalkozás éves, összetett, komplex gazdálkodásának eredménye. Ez a megfelelő szintű eredmény biztosítja a tulajdonosok osztalékelvárását, a bővülő müködési feltételeket, az erőforrások beszerzésének lehetőségét, és nem utolsósorban a fejlesztési lehetőségeket is behatárolja.

Az eredmény alakulásában rengeteg tényező szerepet játszik, csak egy pár példa a teljesség igénye nélkül:

- piacszerző-, marketingtevékenység,

- $\mathrm{K}+\mathrm{F}+\mathrm{I}$,

- termelésszervezés, -irányítás és végrehajtás,

- szellemi és termelőkapacitások kihasználása,

- elvégzett munka minősége,

- munka termelékenységének szintje,

- termelési erőforrásokkal (anyag, energia, emberi erőforrás, technika) való takarékos gazdálkodás,

- vállalkozástól független tényezők (közgazdasági szabályozások, energiaforrások ára, devizaárfolyam).

Időnként szükség lehet az eredmény tervezésére és elemzésére is, mely történhet előzetesen, ez a tervezés, év közben, ami a végrehajtás alatti szakasz elemzési feladata, és természetesen utólagosan is.

A tervezési szakaszban a cél egy optimális eredményterv összeállítása, mely a komplex üzleti terv része, vezérlő elvü, elvárásokat mutat. A reális terv összeállításához szükségünk lesz a megelőző időszak tényszámaira (pl. árbevétel, költségek, cash flow, értékcsökkenés stb.). a költségek részletes adataira, minimum költségnemenként szeretnénk azokat látni, ismerni kell 
a jövőre vonatkozó információkat a piacról, gyártási erőforrásokról, gazdaságosságról, közgazdasági szabályozókról stb. A controlling éves eredménytervezésénél az üzleti vagy más néven bruttó eredményt, tehát az értékteremtő folyamatok eredményét kapjuk meg (Körmendi, Tóth, 2006).

Az elért eredményt viszonyíthatjuk ehhez a tervhez és az előző évben elért eredményhez is. Várható fedezeti összeg folyamatos vizsgálata, fedezeti pont kiszámítása, naprakész tájékoztatás a már elfogadott rendelésekről, kapacitások lekötéséröl, a tervhez képest történő eltérések vizsgálata. Ez egyfajta ellenőrzés, kontroll, bár inkább a controlling témakörbe tartozik, hiszen ez egy időszak alatti terv-tény elemzés. Mivel az időszak még tart, még van idő és lehetőség beavatkozni a folyamatokba, esetleg módosítani a terven, ha az nem volt reális. Az évközi elemzéshez vizsgálunk kell a rendelés-nyilvántartásokat, mennyi a már beérkezett és a még várható megrendelés, vizsgáljuk továbbá a már tárgyalt ÁKF struktúrát, a meghatározó erőforrásokat és azok leterheltségét, ha van bekérjük az évközi mérleget és eredménykimutatást. Ennek az elemzésnek az egyik meghatározó feladata a már szintén tárgyalt fedezeti pont meghatározása. Ismétlésképpen a fedezeti pont olyan nagyságú árbevétel vagy fedezeti összeg, melynél a vállalkozás eredménye pontosan nulla, megmutatja, hogy mikor érjük el évközben ezt a pontot. Ez az időpont akkor fog elérkezni, ha az év elejétől halmozott fedezeti összeg (tömeg) már fedezeti a betervezett közvetett költségeket, az egyéb bevételek, ráfordítások egyenlegét, valamint a pénzügyi mủveletek eredményét is. Ezen információk ismerete fontos, hiszen ennél több bevételt, értékesítést kell produkálnunk, illetve a fedezeti pontként kijelölt nap után érünk be a pozitív eredményü, nyereséges szakaszba.

Az utólagos elemzés, ahogy a neve is mutatja már a gazdálkodási időszak letelte után elemzi az eredményt, az eredményre ható tényezőket, azok változásait és hatásait. A tervhez, illetve az előző évi eredményhez való viszonyításhoz szükségünk lesz a megelőző időszaki, bázisévi tényszámokra és természetesen magára az eredmény- és költségtervekre, amihez viszonyítjuk ezt az időszakot. Ezen adatok a már korábban bemutatott beszámolókban és üzleti tervekben, jelentésekben szerepelnek. A tervtől való eltérést számos tényező okozhatja, például:

- értékesített termékek árszínvonalának változása,

- értékesítés volumenének változása,

- értékesített termékek közvetlen önköltségének változása,

- értékesítés összetételének változása,

- közvetett költségek változása,

- egyéb bevételek és ráfordítások változása,

- pénzügyi müveletek eredményének változása.

Az eredményelemzés részletes módszereinek bemutatását a jegyzet nem tartalmazza. 


\section{Forrásjegyzék}

1) Adorján, Cs., Lukács, J., Róth, J., Veit, J. (2003). Számvitel és elemzés II/B. Budapest: Magyar Könyvvizsgálói Kamara Oktatási Központ Kft.

2) Béhm, I. (1998): Gazdasági-pénzügyi ismeretek. Budapest: Perfekt Gazdasági Tanácsadó Oktató és Kiadó Zrt.

3) Bíró, T., Pucsek, J., Sztanó, I. (2010). Amit a mérleg mutat. Budapest: Saldo Pénzügyi Tanácsadó és Informatikai Zrt.

4) Pucsek, J. (Szerk.) (2016). Vállalkozások tevékenységének komplex elemzése. Budapest: Perfekt Gazdasági Tanácsadó Oktató és Kiadó Zrt.

5) Blumné Bán, E., Kresalek, P., Pucsek, J. (2011). A vállalati elemzés alapismeretei. Budapest: Saldo Pénzügyi Tanácsadó és Informatikai Zrt.

6) Blumné, Bán, E., Kresalek, P., Pucsek, J., Siklósi, Á., Sisa, K. A., Veress, A. (2017). Tételvázlatok a vállalkozási mérlegképes könyvelöi komplex szakmai vizsgához. Budapest: Perfekt Gazdasági Tanácsadó Oktató és Kiadó Zrt.

7) Gál, V. A., Gáspár, K., Parádi-Dolgos, A. (2014). Regional differences in the capital structure of Hungarian SMEs. ACTA UNIVERSITATIS SAPIENTIAE ECONOMICS AND BUSINESS (2)1, 21-36.

8) Gál, V. A. (2014). A magyar kis- és középvállalkozások tőkeszerkezetének sajátosságai. Kaposvár: Gazdálkodás- és Szervezéstudományok Doktori Iskola. Letöltve: 2019. 04. 11. forrás: http://www.gtk.ke.hu/tartalom/doktori/disszertacio_gal_veronika.pdf

9) Konecsny, J. (2013). Vállalati pénzügyek. Letöltve: 2019. 05. 02. forrás: https://www.tankonyvtar.hu/hu/tartalom/tamop412A/2011-0046_vallalati_penzugyek/SCO1/en-us/Content/12_\%20tmakr.html

10) Kovács, I. (2011). Egészségturisztikai kezelések üzleti modellje. Letöltve: 2019. 04. 11. forrás: https://regi.tankonyvtar.hu/hu/tartalom/tamop412A/2010-0019_Egeszsegturisztikai_kezelesek_uzleti_modellje/ch12.html

11) Ladó, L. (1999). A költség- valamint kontrolling témájú vezetői információk helyzetéről. Budapest: Budapest Kiadó. Harvard Business Manager, 1999(2). 56-66.

12) Musinszki, Z. (2013). Mit mutat a mérleg? A hányadoselemzés alapjai és buktatói. CONTROLLER INFO 2013(2), 20-26.

13) Tóth, A., Körmendi, L. (2006). A controlling elmélete és gyakorlata. Budapest: Perfekt Gazdasági Tanácsadó Oktató és Kiadó Zrt.

14) Sebes, J. (2013). Elemzés - Vállalati elemzés - Mérlegelemzés. Budapest: Aura Kiadó

15) Siklósi, Á., Veress, A. (2017). Könyvvezetés és beszámolókészítés. Budapest: Saldo Pénzügyi Tanácsadó és Informatikai Zrt. 


\section{Hatékonyság elemzése}

A hatékonyság fogalmának tisztázásakor fontos elhatárolnunk azt az eredményesség fogalmától. Egy vállalkozást eredményesnek tekintünk, ha a kitüzött célokat sikeresen elérte. Azonban ha egy vállalkozás eredményes az nem feltétlenül jelenti azt, hogy hatékony is, ugyanakkor hatékony müködésröl csak akkor érdemes beszélni, ha a vállalkozásunk eredményesen müködik.

A vállalkozás hatékonyságát az alapján tudjuk megítélni, hogy az eredményeit milyen ráfordításokkal és milyen költségekkel tudta elérni. A hatékonyság tulajdonképpen azt jelenti, hogy az eredetileg kitüzött célokat, eredményeket a lehető legalacsonyabb erőforrás-ráfordítással, költséggel érje el a vállalkozás. Vagy ezt megfordítva, a vállalkozás akkor hatékony, ha a rendelkezésére álló erőforrásaiból a lehető legjobb eredményt éri el. Az elért eredmények (vagy más szóval hozamok) és a ráfordított erőforrások aránya határozza meg a vállalkozás müködésének gazdaságosságát vagy gazdasági hatékonyságát. A gazdasági hatékonyság általános képlettel az alábbi módon fogalmazható meg:

$$
\text { Gazdasági hatékonyság }=\frac{\text { Hozamok }}{\text { Ráfordítások }} \text { vagy } \frac{\text { Ráfordítások }}{\text { Hozamok }}
$$

Előbbi képlet (egyenes mutató) azt fejezi ki, hogy egységnyi ráfordítással mekkora hozamot ért el a vállalkozás, utóbbi mutató (fordított mutató) pedig azt, hogy egységnyi hozam eléréséhez mekkora ráfordításra volt szüksége.

A hatékonyság relatív fogalom, önmagában nem értelmezhető, mindig valamihez viszonyítani szükséges. Vagy az adott vállalkozás hatékonyságát önmaga korábbi időszaki teljesítményéhez, vagy versenytársaihoz, esetleg egy beruházási tevékenységet más beruházási tevékenységekhez. A hatékonyság annyira komplex, hogy vizsgálata sosem történhet csupán egy mutató alapján, hanem mindig több tényező együttes helyzetét kell áttekintenünk, átfogóan elemeznünk.

A hatékonyság vizsgálata annyiban eltérö a jövedelmezőség vizsgálatától (lásd 6. fejezet), hogy hozamként nem csak pénzben mért értékeket használhatunk az elemzések során, hanem természetes mértékegységekben (ún. naturáliában) mért adatokat is.

A hatékonyságot vizsgálhatjuk nemzetgazdasági szinten (makro szint), a vállalkozás szintjén (mikro szint) és a vállalkozáson belül egyes résztevékenységek szintjén is. A vállalkozás tevékenységének hatékonyságát az általa végzett a résztevékenységeknek a hatékonysága határozza meg, valamint az, hogy az egyes résztevékenységek súlya a teljes tevékenységi struktúrában mekkora arányt képvisel.

A fejezet során bemutatásra kerülnek azok a hozammutatók és összefüggéseik, amelyek a hatékonyság mérésekor használhatóak, az erőforrások révén eszközölt, ráfordításokat jellemző mutatók, a tipikusan alkalmazott hatékonysági mutatótípusok, illetve a termelö, kereskedelmi és mezőgazdasági vállalatok esetében értelmezett hatékonysági sajátosságok. 


\subsection{A hozamok és ráfordítások kifejezésére használatos mutatók}

A vállalkozás tevékenységének leggyakrabban használt hozammutatója az értékesítés nettó árbevétele. Ezen kívül pedig további négy - melyböl három közvetlenül származtatható is belőle (7.1. ábra) - teljesítménykategóriát szokás használni a hatékonysági mutatók értékelésekor. Ezek a bruttó termelési érték, az anyagmentes termelési érték, a nettó termelési érték és a hozzáadott érték.

Az értékesítés nettó árbevétele az eredmény-kimutatásból származó adat, amely a vállalkozás által értékesítésre került termékek és szolgáltatások árbevételét foglalja magában az általános forgalmi adóval csökkentetten.

Ennél bizonyos értelemben szűkebb kategória a bruttó termelési érték, amely már nem tartalmazza azon termékek és szolgáltatások beszerzési értékét, amelyeket a vállalkozás változatlan formában továbbad vagy közvetít (tehát valójában csak ezek árrését foglalja magában). Ugyanakkor annyiban pedig tágabb kategória, hogy tartalmazza azon tevékenységek értékét (saját termelésü eszközök és készletek), amelyek ugyan értékesítésre nem kerülnek partner számára, de eredményük beépül a vállalkozás üzletmenetébe, azokat akár hosszabb távon is felhasználja a tevékenysége során.

A bruttó termelési értéket csökkentve a termeléshez felhasznált anyagköltséggel és az igénybe vett anyag jellegű szolgáltatások költségével - azaz azon felhasznált anyagok költségeivel, amelyeket átalakítva a vállalkozás előállítja saját késztermékeit és azon szolgáltatások költségeivel, amelyeket a vállalkozás igénybe vett termékei előállításához (pl. más vállalkozóval végeztetett fuvarozási, szállítási és rakodási költség, csomagolási költség, bérmunkadíj, posta-, távíró-, telefon- és telexköltség, stb.) - megkapjuk az anyagmentes termelési értéket. Különösen fontos lehet ennek alakulása az anyagigényes tevékenységet folytató vállalkozásoknál.

$\mathrm{Az}$ anyagmentes termelési értéknél tovább szükített mutató a nettó termelési érték, amely előbbit az értékcsökkenési leírás összegével tovább csökkenti, ezzel tulajdonképpen nagyjából megadja a vállalkozás hozzájárulását a nemzeti jövedelemhez. A mutató egyúttal a vállalkozás által ténylegesen létrehozott új értéket jelenti. 


\begin{tabular}{|c|}
\hline $\begin{array}{l}\text { Értékesítés nettó árbevétele } \\
\text { - ELÁBÉ } \\
\text { - Eladott (közvetített) szolgáltatások értéke } \\
\text { + Saját előállítású eszközök aktivált értéke } \\
\text { 土 Saját termelésú készletek állományváltozása }\end{array}$ \\
\hline $\begin{array}{l}\text { Bruttó termelési érték } \\
\text { - Anyagköltség } \\
\text { - Igénvbe vett anvag jellegủ szolgáltatások }\end{array}$ \\
\hline $\begin{array}{l}\text { Anyagmentes termelési érték } \\
\text { - Értékcsökkenési leírás }\end{array}$ \\
\hline Nettó termelési érték \\
\hline
\end{tabular}

7.1. ábra Az értékesités nettó árbevételéhez köthető hozamkategóriák összefüggései

Forrás: Bíró és mtsai (2010)

A nettó termelési értékhez nagyon hasonlító mutató a hozzáadott érték mutatója, amely a GDP megfelelöje a vállalkozások szintjén (7.2. ábra).

$$
\begin{aligned}
& \text { Személyi jellegü ráfordítások } \\
& \text { + Értékcsökkenési leírás } \\
& \text { + Adózás előtti eredmény } \\
& \text { Hozzáadott érték }
\end{aligned}
$$

\section{2. ábra Az értékesités nettó árbevételéhez köthető ho- zamkategóriák összefüggései}

Forrás: Bíró és mtsai (2010)

A hozammutatók mellett a hatékonysági számítások másik elemét a ráfordításokat mérő mutatók jelentik. Ezek közé tartoznak az alábbiak:

- átlagos foglalkoztatotti létszám (átlagos statisztikai létszám);

- bérköltség vagy a teljes személyi jellegü ráfordítások;

- termelésben lekötött tárgyi eszközök (azaz olyan eszközök, berendezések gépek stb., amelyek a vállalkozás müködéséhez alapvetően szükségesek és másra nem is lehet használni őket, nem átkonvertálhatók más tevékenység végzéséhez), immateriális javak átlagos értéke;

- termelésben lekötött készletek átlagos értéke;

- lekötött eszközök nettó értéke;

- összes eszközérték;

- összes termelési költség;

- export értékesítés költségei. 
Fontos megjegyezni, hogy a ráfordításokat mérő mutatók átlagos értéke alatt kronologikus átlagokat értünk, melyek lehetnek negyedévesek, félévesek vagy évesek is a vizsgálat időhorizontjától függően. A kronologikus átlag képzése során a vizsgált időszakok értékei úgy kerülnek átlagolásra, hogy az első és utolsó időszak adatainak csak felét szerepeltetjük, a nevezőben pedig az átlagolandó értékek száma mínusz egy szerepel.

\section{2. Ágazattól függetlenül használható hatékonysági mutatók}

A legáltalánosabban használt mutatók, melyek gyakorlatilag minden ágazatra alkalmazhatóak, a forgási mutatók. Két alapmutatójuk a forgási sebesség és a forgási idő. A forgási sebesség a fordulatok számát adja meg, azaz azt, hogy adott ráfordítás adott hozamban hányszor térül meg a vizsgált időtartam során (7.1. táblázat). A forgási idő napokban adja meg azt, hogy hány nap szükséges adott ráfordítás egyszeri megtérüléséhez a vizsgált időszakon belül. Jellemzően a készletekre, a vevőkre és a szállítókra szokás számítani (7.2. táblázat). Utóbbi kettő szokásos elnevezése a vevői futamidő és a szállítói futamidő. A vevői futamidő megadja, hogy átlagosan az összes vevői állományt tekintve hány nap telik el a termék értékesítése és annak vevő részéről történő kiegyenlítése között. A szállítói futamidő pedig azt adja meg, hogy átlagosan a teljes szállítói állományt figyelembe véve, hány nap telik el a termék beszerzése és annak a vállalkozás részéről a szállító irányába történő kifizetése között.

\section{1. táblázat Forgási sebesség mutatók (fordulatokban kifejezve)}

\begin{tabular}{|c|c|}
\hline Mutató megnevezése & Mutató \\
\hline \multicolumn{2}{|c|}{$\begin{array}{l}\text { Eszközök forgási sebessége } \\
\end{array}$} \\
\hline \multirow{2}{*}{ Eszközök forgási sebessége } & Értékesítés nettó árbevétele \\
\hline & Összes eszköz átlagos értéke \\
\hline \multirow{2}{*}{ Befektetett eszközök forgási sebessége } & Értékesítés nettó árbevétele \\
\hline & $\overline{\text { Befektetett eszközök átlagos értéke }}$ \\
\hline \multirow{2}{*}{ Tárgyi eszközök forgási sebessége } & Értékesítés nettó árbevétele \\
\hline & $\overline{\text { Tárgyi eszközök átlagos értéke }}$ \\
\hline \multirow{2}{*}{ Forgóeszközök forgási sebessége } & Értékesítés nettó árbevétele \\
\hline & $\overline{\text { Forgóeszközök átlagos értéke }}$ \\
\hline \multirow{2}{*}{ Készletek forgási sebessége } & Értékesítés nettó árbevétele \\
\hline & Készletek átlagos értéke \\
\hline \multirow{2}{*}{ Árukészletek forgási sebessége } & Értékesítés nettó árbevétele \\
\hline & $\overline{\text { Árukészletek átlagos értéke }}$ \\
\hline \multicolumn{2}{|c|}{ Források forgási sebessége } \\
\hline \multirow{2}{*}{ Saját tőke forgási sebessége } & Értékesítés nettó árbevétele \\
\hline & Saját tőke átlagos értéke \\
\hline \multirow{2}{*}{ Idegen tőke forgási sebessége } & Értékesítés nettó árbevétele \\
\hline & $\overline{\text { Idegen tôke (Kötelezettségek) átlagos értéke }}$ \\
\hline
\end{tabular}




\begin{tabular}{|l|c|}
\hline Müködőtőke forgási sebessége & $\frac{\text { Értékesítés nettó árbevétele }}{n}$ \\
\hline Forgótőke forgási sebessége & $\frac{\text { Múködőtőke átlagos értéke }}{\text { Forgótés nettó árbevétele }}$ \\
\hline
\end{tabular}

Forrás: Béhm (1998)

\section{2. táblázat Forgási idő mutatók (napokban kifejezve)}

\begin{tabular}{|l|c|}
\hline \multicolumn{1}{|c|}{$\begin{array}{c}\text { Mutató megneve- } \\
\text { zése }\end{array}$} & \multicolumn{1}{c|}{ Mutató } \\
\hline $\begin{array}{l}\text { Készletek forgási } \\
\text { ideje }\end{array}$ & $\begin{array}{c}\text { Készletek átlagos nettó értéke } \times \text { Időszak napjainak száma } \\
\text { Értékesítés nettó árbevétele }\end{array}$ \\
\hline $\begin{array}{l}\text { Vevőállomány for- } \\
\text { gási ideje }\end{array}$ & $\frac{\text { Vevőállomány átlagos nettó értéke } \times \text { Időszak napjainak száma }}{\text { Értékesítés nettó árbevétele }}$ \\
\hline $\begin{array}{l}\text { Szállítóállomány } \\
\text { forgási ideje }\end{array}$ & $\frac{\text { Szállítóállomány átlagos nettó értéke } \times \text { Időszak napjainak száma }}{\text { Értékesítés nettó árbevétele }}$ \\
\hline
\end{tabular}

Forrás: Béhm (1998)

A forgási sebesség és a forgási idő közötti összefüggést szemlélteti az alábbi képlet:

$$
\text { Forgási idő }=\frac{\text { Vizsgált időszak napjainak száma }}{\text { Forgási sebesség fordulatokban }}
$$

A forgási sebességet és a forgási időt értékelve figyelni kell arra, hogy változásuk ellentétes irányú. Ha a forgási sebesség (fordulatokban kifejezve) nő, az azt jelenti, hogy a forgási sebesség gyorsul, gyorsabban megtérülnek a ráfordítások. Ha ugyanez csökken, akkor lassulásról beszélünk. Ha a forgási idő (napokban kifejezve) nő, az azt jelenti, hogy a forgási sebesség lassul, több napra van szükség adott ráfordítás megtérüléséhez. Ha ugyanez az érték csökken, akkor a forgási sebesség gyorsulásáról beszélünk.

Jellemzően kedvezőnek tekintjük azt, ha a forgási sebesség gyorsul, hiszen ez azt jelenti, hogy a vállalkozás ráfordításait gyorsabban képes árbevételében megtermelni. Negatív irányba befolyásolhatja a forgási sebesség alakulását, ha a vállalkozás jelentős eszközberuházást végez, amely jelenség azonban a beruházás jövőben várható magasabb megtérülési potenciálja miatt mégsem tekinthető negatívnak. Ellenben, ha a vállalkozás készletei az optimálishoz képest alacsonyabbak, akkor a forgási sebesség mutatója az iparági átlagnál jobb lehet, azonban ez mégsem feltétlenül értékelhető pozitívan, hiszen az alacsony készletszint értékesítési nehézségekhez vagy termelési fennakadásokhoz vezethet.

Az egyes vállalkozások tevékenységének jellege, illetve a tevékenységek összetétele alapvetően befolyásolja a forgási sebesség mutatóinak értékét, ezért általánosítható elvárt értéket nem lehet meghatározni. 
A forgási sebességet mérő mutatók köréhez tartoznak az ún. átfutási időt mérő mutatók is, melyek tulajdonképpen úgyszintén napokban mérik a forgási sebességet, csak más megközelítésből. Azt vizsgálják, hogy adott eszköz vagy forrásfajta mennyi időt tölt a vállalkozás gazdasági folyamataiban (7.3. táblázat).

\section{3. táblázat Átfutási idő mutatók (napokban kifejezve)}

\begin{tabular}{|l|c|}
\hline Mutató megnevezése & Mutató \\
\hline $\begin{array}{l}\text { Tárgyi eszközök átfu- } \\
\text { tási ideje }\end{array}$ & Tárgyi eszközök átlagos értéke $\times 365$ \\
\hline $\begin{array}{l}\text { Aktivált tárgyi eszkö- } \\
\text { zök átfutási ideje }\end{array}$ & \begin{tabular}{c} 
Ekrtékcsökkenési leírás + Tárgyi eszközök állománycsökkenése \\
\hline $\begin{array}{l}\text { Forgóeszközök átfu- tárgyi eszközök átlagos értéke } \times 365 \\
\text { tási ideje }\end{array}$ \\
\hline Vevők átfutási ideje
\end{tabular} \\
\hline Szállítók átfutási ideje & $\frac{\text { Forgóeszközök átlagos értéke } \times 365}{\text { Értékesítés nettó árbevétele }}$ \\
\hline
\end{tabular}

Forrás: Zéman - Béhm (2016)

Az előzőkhez hasonlóan úgyszintén általánosan használhatóak azok a mutatók, amelyek bizonyos készletfajták a vizsgált időszakra vonatkozó átlagos állománya és a hozzájuk kapcsolódó költségek összevetését mutatják be. Ilyenek lehetnek például a továbbértékesített áruk vagy a saját termelésü készletek.

$$
\begin{aligned}
& \frac{\text { Eladott áruk beszerzési értéke (ELÁBÉ) }}{\text { Árukészletek átlagos értéke }} \\
& \frac{\text { Értékesítés elszámolt közvetlen költsége }}{\text { Saját termelésű készletek átlagos értéke }}
\end{aligned}
$$

Szintén ebbe a csoportba sorolhatók az ún. rugalmassági mutatók, amelyek a hozamok és ráfordítások között azáltal teremtenek kapcsolatot, hogy megvizsgálják az egyikben bekövetkező változás mértékét, ill. annak hatását a másik mutatóra. A hozamkategóriák közül az értékesítés nettó árbevétele, ill. a termelési érték valamely kategóriája kerül összevetésre valamely eszközvagy forráskategóriával, valamint esetlegesen a vállalkozás eredményével. A rugalmassági együtthatók számlálója és nevezője felcserélhető egymással, így beszélhetünk vonzat-, ill. igényesség mutatókról. Általánosan megfogalmazva azt fejezik ki ezek a mutatók, hogy az egyik vizsgált tényezőben bekövetkező 1\%-os változás hány százalékos változást eredményez a másik mutatóban (vonzat), ill. megfordítva, hány százalékos változásra van szükség ahhoz az egyik mutatóban, hogy a másik éppen 1\%-kal változzon (igényesség). A vonzat- ill. igényesség mutatókat általánosan mutatja be a 7.4. táblázat, valamint a munkaerőben bekövetkező létszám változásával egy konkrét példát az 


\section{4. táblázat Erőforrás és árbevétel rugalmassági mutatók}

\begin{tabular}{|l|c|}
\hline $\begin{array}{c}\text { Mutató megne- } \\
\text { vezése }\end{array}$ & \multicolumn{1}{c|}{ Mutató } \\
\hline Vonzat mutató & $\frac{\text { árbevétel \% - os változása a vizsgált időszakhoz képest }}{\text { felhasznált erőforrás \% - os változása a vizsgált időszakhoz képest }}$ \\
\hline $\begin{array}{l}\text { Igényesség mu- } \\
\text { tató }\end{array}$ & $\frac{\text { felhasznált erőforrás \% - os változása a vizsgált időszakhoz képest }}{\text { árbevétel \% - os változása a vizsgált időszakhoz képest }}$ \\
\hline
\end{tabular}

7.5. táblázat Vonzat- és igényesség mutatóra példák

\begin{tabular}{|l|c|}
\hline $\begin{array}{c}\text { Mutató megne- } \\
\text { vezése }\end{array}$ & \multicolumn{1}{c|}{ Mutató } \\
\hline Vonzat mutató & $\frac{\text { árbevétel \% - os változása a vizsgált időszakhoz képest }}{\text { munkaerő - létszám \% - os változása a vizsgált időszakhoz képest }}$ \\
\hline $\begin{array}{l}\text { Igényesség mu- } \\
\text { tató }\end{array}$ & $\frac{\text { munkaerő - létszám \% - os változása a vizsgált időszakhoz képest }}{\text { árbevétel \% - os változása a vizsgált időszakhoz képest }}$ \\
\hline
\end{tabular}

\subsection{Termelő vállalatok hatékonyságát értékelő mutatók}

A termelő vállalkozások esetében használható mutatók között jelen fejezet tárgyalja az ún. komplex hatékonysági mutatót (mint globális hatékonysági mutatót), illetve több parciális hatékonysági mutatót is: élőmunka-hatékonyság és bérhatékonyság mutatók, eszközhatékonysági mutatók, termelési költségszint mutató, ill. tőkehatékonyság.

\subsubsection{Komplex hatékonysági mutató}

A komplex hatékonyság mutatója attól komplex, hogy a vállalkozás két legfontosabb erőforrástípusának, a lekötött eszközeinek és az emberi erőforrásainak (ill. az ahhoz kapcsolódó bérköltségének) hatékony felhasználását vizsgálja, és ezek mértékéhez viszonyítja a nettó termelési értéket. A mutató nevezőjében szereplő két erőforrástípus súlyozottan jelenik meg, mely súlyok azt jelképezik, hogy milyen megtérülést vár el a vállalkozás ezektől az erőforrásoktól. A nettó lekötött eszközérték általánosan elfogadott súlyszáma 0,15 (ami kb. 7 éves átlagos élettartamú eszközöket feltételez), de amennyiben a vállalkozás gyorsan avuló eszközökkel rendelkezik, akkor ennek értéke magasabb is lehet. A bérköltségek esetében az általánosan elfogadott súlyérték 1,7, azaz a vállalkozások esetében elvárható, hogy a kifizetett bérek 1,7szeresét kell kitermelniük a munkavállalóknak. Az említett súlyértékek általánosan iránymutató jellegüek, a vállalkozás saját döntésétől függ, ha ezeket megváltoztatja attól függően, hogy milyen mértékben várja el erőforrásai megtérülését.

Nettó termelési érték

$\overline{0,15 \times \text { Nettó lekötött eszközérték }+1,7 \times \text { Bérköltség }}$ 
A komplex hatékonyság mutatójának elvárt értéke 1 feletti, mert ebben az esetben képes megtermelni azt a nettó termelési értéket, amelyet a vállalkozás elvár az erőforrásainak felhasználásáért cserébe.

\subsubsection{Parciális hatékonysági mutatók}

Ahogyan elnevezésük is mutatja, ezek a mutatók nem összevontan elemzik több vállalkozási erőforrás hatékony felhasználását, hanem csak egy-egy erőforrásfajtára koncentrálnak. Általánosan megfogalmazható, hogy kizárólag önmagukban nem lehet csak ezek alapján megítélni a vállalkozás müködésének hatékonyságát, hanem összefüggéseikben kell értékelni öket. A parciális hatékonysági mutatók számlálójában azon hozammutatók alkalmazhatóak, amelyek a 7.1-es fejezetben bemutatásra kerültek.

\subsubsection{1. Élőmunka és bérköltség hatékonysági mutatói}

A vállalkozások egyik legfontosabb - ha nem a legfontosabb - erőforrása a munkaerő, melynek hatékonysági elemzése történhet a munkaerő létszámára vetítetten (7.6. táblázat) vagy a munkaerő alkalmazásához kapcsolódó kiadásokra (bérköltségek, személyi jellegü juttatások) vetítetten (7.7. táblázat). Jellemzően azoknál a tevékenységeknél fontosak az ilyen mutatók, ahol a létszám-, ill. a munkaerőigény és az elérhető árbevétel között szoros kapcsolat van.

7.6. táblázat Élömunka-hatékonyság mutatói

\begin{tabular}{|c|l|}
\hline Mutató képlete & \multicolumn{1}{c|}{ Mutató jelentése } \\
\hline \begin{tabular}{c|c} 
Értékesítés nettó árbevétele \\
Létszám
\end{tabular} & $\begin{array}{l}\text { Egy fóre jutó nettó értékesítési árbevé- } \\
\text { tel }\end{array}$ \\
\hline$\frac{\text { Termelési érték }}{\text { Létszám }}$ & Egy före jutó termelési érték \\
\hline
\end{tabular}

A 7.6. táblázat az egy före jutó bevételi, ill. termelési értékek mutatóit (melyek a 7.1-es fejezet kategóriái lehetnek) tartalmazza a teljes foglalkoztatotti létszámra vetítve (a vizsgált időszak átlagos létszámadataival számolva). Szokás a mutatókat külön a fizikai és külön a szellemi munkavállalókra szétbontani. Tulajdonképpen ezek a mutatók jelentik az élőmunka termelékenységét a vállalkozásnál. 


\begin{tabular}{|l|l|}
\hline \multicolumn{1}{|c|}{ Mutató képlete } & \multicolumn{1}{c|}{ Mutató jelentése } \\
\hline$\frac{\text { Értékesítés nettó árbevétele }}{\text { Bérköltség }} \times 1000$ & $\begin{array}{l}\text { Ezer forint bérköltségre jutó nettó árbe- } \\
\text { vétel }\end{array}$ \\
\hline$\frac{\text { Értékesítés nettó árbevétele }}{\text { Személyi jellegú ráfordítások }} \times 1000$ & $\begin{array}{l}\text { Ezer forint személyi jellegű ráfordításra } \\
\text { jutó nettó árbevétel }\end{array}$ \\
\hline
\end{tabular}

A 7.7. táblázat mutatói tulajdonképpen a ráfordításként jelentkező kifizetések értékteremtő képességét hivatottak kifejezni, azaz azt, hogy 1000 Ft ráfordítással a vállalkozás hány forint értéket képes előállítani. A személyi jellegü ráfordítások vetítési alapként történő használata a munkaerőhöz kapcsolódó ráfordításokat szélesebb körben értelmezi, ennek megfelelően az ilyen mutatók értéke alacsonyabb, mint a bérköltséget vetítési alapnak használó mutatóké. Fontos megjegyezni, hogy a 7.6. táblázatban található mutatók mintájára a 7.7. táblázat mutatói esetében is alkalmazható a számlálóban a bruttó-, az anyagmentes- vagy a nettó termelési érték, ill. a hozzáadott érték is.

Kimondottan kívánatos határérték jelen fejezet egyik mutatója esetében sem definiálható, de értelemszerüen minél magasabb az értékük, annál kedvezőbb és annál hatékonyabb müködést mutatnak - célszerü a vállalkozás korábbi teljesítményéhez, vagy a versenytársak teljesítményéhez viszonyítani.

\subsubsection{Eszközhatékonyság mutatói}

Anyagköltség

+ Igénybe vett (anyagjellegü és nem anyagjellegü) szolgáltatások értéke

+ Egyéb szolgáltatások értéke

+ Személyi jellegü ráfordítások

+ Értékcsökkenési leírás

Összes termelési költség

7.3. ábra Az összes termelési költség kalkulációja

Forrás: Bíró és mtsai. (2016)

A vállalkozások további nagyon fontos erőforrásait képezik a termelésben résztvevő eszközök és készletek, melyek hatékonyságának értékelése annál fontosabb, minél inkább tőkeigényes iparágról van szó. 


\begin{tabular}{|c|l|}
\hline Mutató képlete & \multicolumn{1}{|c|}{ Mutató jelentése } \\
\hline Termelési érték & Lekötött eszközök hatékonysága \\
\hline $\begin{array}{c}\text { Lekötött eszközök átlagos nettó értéke } \\
\text { Termelési érték }\end{array}$ & Tárgyi eszköözök hatékonysága \\
\hline$\frac{\text { Termelési érték }}{\text { Készletek átlagos értéke }}$ & Készletek hatékonysága \\
\hline
\end{tabular}

A 7.8. táblázatban található mutatók esetében valamely, a vállalkozás által ténylegesen a termelésben használt eszközkategóriára vetítetten jelennek meg a termelési érték kategóriák (lásd. 7.1-es fejezet). Fontos megjegyezni, hogy vetítési alapként a befektetett pénzügyi eszközöket nem használjuk, hiszen azok nem vesznek részt ténylegesen a termelö folyamatokban, ellenben a 7.8. táblázatban szereplő vetítési alapok mellett használhatóak még például az immateriális javak is.

Ezek a mutatók azok, amelyek a használt eszközök termelésben való újraképződését hivatottak jellemezni. Általánosságban elmondható róluk, hogy az eszközállomány növekedése a mutatók értékét rontja, azonban ha ez a romlás csak rövidtávon következik be, akkor nem értékelhető valódi problémaként, hisz az eszközökbe történő beruházás sok esetben csak hosszabb távon térül meg. Ezért célszerü e mutatók alakulását hosszabb távon, idősorosan vizsgálni.

\subsubsection{Termelési költségek hatékonysági mutatói}

A termelési költségek hatékonysági mutatói esetében első lépésben meg kell határozni, hogy mely költségelemekből tevődik össze a teljes termelési költség (7.3. ábra).

Az eszközök és a bérköltségek, ill. személyi ráfordítások körén túlmenően a teljes termelési költségek és a velük megtermelt termelési érték viszonya is számszerüsíthető. Ez tulajdonképpen a költségarányos termelési érték (vagy árbevétel) mutatója, ami megadja, hogy 1000 Ftnyi költségre mekkora hozam jut. Értéke annál kedvezőbb, minél magasabb.

$$
\frac{\text { Bruttó termelési érték vagy Értékesítés nettó árbevétele }}{\text { Összes termelési költség }} \times 1000
$$

Fordított hatékonysági mutatóként értelmezhető a termelési költségszint mutatója, amely a termelőtevékenység során a vizsgált időszakban felmerülő költségek összességét veszi számba és viszonyítja az e költségek eredményeként létrejött bruttó termelési értékhez, százalékos formában mutatja meg a költségszintet. Értéke annál kedvezőbb, minél inkább elmarad a 100\%-os értéktől.

$\frac{\text { Összes termelési költség }}{\text { Bruttó termelési érték }} \times 100$ 
Mindkét termelési költség mutatót célszerü hosszabb időtávon keresztül vizsgálni, bár adott időpontbeli értéke is fontos információkat tartalmazhat.

\subsubsection{Töke- és eredményhatékonysági mutatók}

A mutatók e csoportjába a vállalkozás saját tőkéjének hatékonyságát, ill. a vállalkozás által elért eredmény hatékonyságát vizsgáló mutatók tartoznak.

A tőkehatékonysági mutatók jelzik, hogy a vállalkozás saját tőkéje mekkora termelési értéket képes létrehozni (ismét használhatók a 7.1-es fejezet termelési érték kategóriái).

Tulajdonképpen a saját tőke egyfajta forgási sebességének is felfoghatók ezek a mutatók. Speciális esete a tőkearányos vállalkozási pénzjövedelem mutatója, ahol a vállalkozási pénzjövedelmet az adózott eredmény és az értékcsökkenési leírás összegéböl számítjuk (7.9. táblázat).

7.9. táblázat Tökehatékonysági mutatók

\begin{tabular}{|c|l|}
\hline Mutató képlete & \multicolumn{1}{|c|}{ Mutató jelentése } \\
\hline Termelési érték & $\begin{array}{l}\text { Saját tőke hatékonysága, egységnyi sa- } \\
\text { ját tőkével mekkora termelési érték jött } \\
\text { létre. }\end{array}$ \\
\hline Vállalkozási pénzjövedelem & $\begin{array}{l}\text { Tőkearányos vállalkozási pénzjövede- } \\
\text { lem, egységnyi saját tőkével mekkora } \\
\text { vállalkozási pénzjövedelem jött létre. }\end{array}$ \\
\hline Saját tőke &
\end{tabular}

A tőkehatékonysági mutatók annál kedvezőbbek, minél magasabb az értékük, jellemzően ezek esetében is a tendenciákat érdemes vizsgálni. (Szükség esetén a saját tőke helyébe más tőketípusok is helyettesíthetők: pl. forgótőke, idegen tőke stb.)

Az eredményhatékonysági mutatók esetében az üzemi (üzleti) tevékenység eredményét viszonyítjuk az értékesítés nettó árbevételéhez, ugyanis ez az eredménykategória az, amely tisztán az értékesítési árbevételből jön létre és nem rakódnak hozzá más jellegű bevételek (pl. pénzügyi müveletek bevételei stb.) (7.10. táblázat). 
7.10. táblázat Eredményhatékonysági mutatók

\begin{tabular}{|c|l|}
\hline \multicolumn{1}{|c|}{ Mutató képlete } & \multicolumn{1}{|c|}{ Mutató jelentése } \\
\hline$\frac{\text { Értékesítés nettó árbevétele }}{\text { Üzemi (üzleti) tevékenység eredménye }} \times 100$ & $\begin{array}{l}\text { Eredményarányos árbevétel, mekkora } \\
\text { árbevételre van szükség 100 Ft-nyi } \\
\text { eredmény eléréséhez. }\end{array}$ \\
\hline$\frac{\text { Üzemi (üzleti) tevékenység eredménye }}{\text { Értékesítés nettó árbevétele }} \times 100$ & $\begin{array}{l}\text { Árbevétel-arányos eredmény, 100 Ft- } \\
\text { nyi árbevételből hány Ft-nyi eredmény } \\
\text { képződik. }\end{array}$ \\
\hline
\end{tabular}

Míg az eredményarányos árbevétel esetében a minél alacsonyabb, addig az árbevétel-arányos eredmény esetében a minél magasabb érték a kedvezö.

\subsection{Kereskedelmi vállalatok hatékonyságát értékelő mutatók}

A kereskedelmi vállalatok elemzése során azok jellegzetességéböl adódóan az általánosan használt hatékonysági mutatók mellett érdemes más, sajátosan ennek az ágazatnak a jellemzőit jobban megragadó mutató használata is. Az egyik ilyen sajátosság a fokozott emberi erőforrás szükséglet és az ebből adódó ráfordítások (melyek mérhetők létszámadatokkal, ledolgozott munkaórákkal és ezek költségeivel), a másik sajátosság pedig, hogy a termelő vállalatoktól eltérő hozamkategóriák jobban megfelelnek e vállalkozások értékeléséhez, hiszen itt valódi termelö, átalakító tevékenység nem történik, inkább közvetítő tevékenység csak.

Így a kereskedelmi vállalatok esetében használatos hozamkategóriák az alábbiak:

- értékesítés nettó árbevétele (megegyezik a termelő vállalatokkal);

- realizált árrés-tömeg;

- az értékesítési forgalom összege, mely tartalmazza az árrés-tömeget és a forgalmi adó összegét is.

Mindezek mellett a kereskedelemben is használatosak eszközhatékonysági mutatók, melyek eltérnek a termelő vállalatok mutatóitól és elsősorban a kereskedelmi tevékenységben hasznosított létesítményekre és technikai eszközökre összepontosítanak.

\subsection{1. Élőmunka-hatékonyság mutatói a kereskedelemben}

Mivel az emberi erőforrás és annak hatékonysága kiemelt jelentőségű a kereskedelmi vállalkozások esetén, ezért néhány, erre a szektorra jellemzően alkalmazandó mutatót mutat be jelen fejezet (7.11. táblázat), azonban ezek mellett a 7.3.2.1-es fejezetben bemutatott mutatók szintén használhatóak. 
7.11. táblázat A kereskedelmi vállalkozások élömunka-hatékonyságát jellemző mutatók

\begin{tabular}{|c|c|}
\hline Mutató képlete & Mutató jelentése \\
\hline$\frac{\text { Forgalom }}{\text { Létszám }}$ & 1 före jutó forgalom \\
\hline$\frac{\text { Forgalom }}{\text { Ledolgozott munkaórák száma }}$ & 1 ledolgozott munkaórára jutó forgalom \\
\hline$\frac{\text { Vásárlások száma }}{\text { Létszám }}$ & $\begin{array}{l}\text { Dolgozók leterheltsége, } 1 \text { főre jutó vá- } \\
\text { sárlások száma. }\end{array}$ \\
\hline$\frac{\text { Forgalom }}{\text { Vásárlások száma }}$ & $\begin{array}{l}\text { Minőségi mutató, egy vásárlásra jutó } \\
\text { forgalom }\end{array}$ \\
\hline$\frac{\text { Vásárlások száma }}{\text { Forgalom }} \times 1000$ & $\begin{array}{l}\text { Forgalom munkaigényessége, } 1000 \text { Ft- } \\
\text { nyi forgalom eléréséhez hány vásárlást } \\
\text { kell lebonyolítani. }\end{array}$ \\
\hline$\frac{\text { Létszám }}{\text { Vásárlások száma }}$ & $\begin{array}{l}\text { Áru munkaigényessége, } 1 \text { vásárláshoz } \\
\text { hány fớnyi létszámra van szükség. }\end{array}$ \\
\hline$\frac{\text { Ledolgozott munkaórák száma }}{\text { Vásárlások száma }}$ & $\begin{array}{l}\text { Áru munkaigényessége, } 1 \text { vásárláshoz } \\
\text { hány órányi ledolgozott munkaidőre } \\
\text { van szükség. }\end{array}$ \\
\hline
\end{tabular}

A 7.11. táblázatban bemutatott, a forgalmat tartalmazó mutatók esetében a forgalom alatt az értékesítés nettó árbevételét értjük.

Az egy före jutó teljesítmény mutatót szokás közvetlen teljesítménymutatónak is hívni. Ennek részletezettebb formája a ledolgozott munkaórákra vetített forgalom értéke, mely azért lehet pontosabb, mert a létszámadatok esetében problémát jelenthet a teljes vagy részfoglalkozású munkavállalók figyelembe vétele. Fontos megjegyezni, hogy a forgalmi adatokat idősoros összehasonlítás esetén úgy kell számba venni, hogy az árak változásának hatása kiszürésre kerüljön, azaz változatlan árakkal kell kalkulálni.

A dolgozók leterheltsége és a minőségi mutató ún. közvetett teljesítménymutatók, melyek azokat a hatásokat részletezik, amelyek a teljesítményre közvetett módon még hatással vannak. Bár a magas forgalom alapvetően pozitívan értékelhető a kereskedelmi vállalkozások esetében, de ez együtt járhat a vásárlások magas számával is, amely fokozottan igénybe veheti a dolgozók munkaidejét, figyelmét. Ennek az igénybevételnek a mértékét számszerüsíti a dolgozók leterheltsége. Természetesen az sem jó, ha ennek értéke túl magas - mert ekkor túlterheltek a munkavállalók - és az sem, ha túl alacsony - mert ekkor kihasználatlan a munkaerő-kapacitás. Másik aspektusból vizsgálja ezt a kérdést a minőségi mutató aszerint, hogy egy-egy vásárlásra mekkora átlagos forgalom jut. Annál kedvezőbb, minél magasabb az értéke.

A két közvetett teljesítménymutató reciproka a munkaigényességi mutatók közé tartozik. A forgalom munkaigényessége azt méri, hogy 1000 forintnyi forgalomra jutóan hány vásárlást kell lebonyolítani, míg az áru munkaigényessége azt, hogy egy vásárlás lebonyolításához hány főnyi munkavállalóra van szükség. 


\subsubsection{Eszközhatékonyság mutatói a kereskedelemben}

A kereskedelmi vállalkozások eszközei közül a létesítmények nyújtják a kereskedelmi tevékenység végzésének helyszínét, míg a technikai eszközök a tevékenységek operatív elvégzéséhez szükséges segítséget (pl. árumozgatás, tárolás, beszerzés stb.). Ezekhez az eszközökhöz kapcsolódó hatékonysági mutatókat foglalja össze a 7.12. táblázat. Ezeknél a mutatóknál célszerü a vizsgált időszakban használt eszközök átlagos értékét használni - csakúgy, mint a létszámadatok esetében.

7.12. táblázat Eszközhatékonysági mutatók a kereskedelemben

\begin{tabular}{|c|l|}
\hline \multicolumn{1}{|c|}{ Mutató képlete } & \multicolumn{1}{c|}{ Mutató jelentése } \\
\hline \begin{tabular}{c|l} 
Eszközállomány értéke \\
Kereskedelmi alapterület
\end{tabular} & $\begin{array}{l}\text { Eszközellátottság, egy m²-re jutó esz- } \\
\text { közállomány értéke. }\end{array}$ \\
\hline$\frac{\text { Eszközállomány értéke }}{\text { Összes létszám }}$ & $\begin{array}{l}\text { Technikai felszereltség, egy dolgozóra } \\
\text { jutó eszközállomány értéke. }\end{array}$ \\
\hline Forgalom & $\begin{array}{l}\text { Eszközhatékonyság, 1000 Ft-nyi esz- } \\
\text { közállománnyal elért forgalom értéke. }\end{array}$ \\
\hline Eszközállomány értéke & Eszközállomány értéke \\
\hline Forgalom & $\begin{array}{l}\text { Eszközigényesség, 1000 Ft-nyi forga- } \\
\text { lom eléréséhez szükséges eszközállo- } \\
\text { mány értéke. }\end{array}$ \\
\hline
\end{tabular}

Az eszközellátottság mutatójának magas értéke azt jellemzi, hogy feltehetően magas értékü és teljesítőképességű eszközökkel ellátott a vállalkozás. Értéke értelemszerüen megugrik eszközberuházások esetén, ill. csökken új kereskedelmi infrastruktúra bevonásával. Hasonlóan magyarázható a kereskedelmi munka technikai felszereltségének mutatója is.

Az eszközhatékonyság az eszközök felhasználásának forgalomhoz mért hatékonyságát mutatja be, amely mutató reciproka az eszközigényességet mutatja be, azaz milyen eszközértékre van szükség 1000 forintnyi forgalom lebonyolításához.

\subsection{Mezőgazdasági vállalatok hatékonyságát értékelö mutatók}

A mezőgazdaságban tevékenykedő vállalkozások különlegességét az adja, hogy sok esetben a vállalkozáson belül a különböző termelőtevékenységek erőteljes vertikális integrációja valósul meg. Azaz például a vállalkozás egyaránt foglalkozik növénytermesztéssel és állattenyésztéssel is, és az előállított takarmányt nem - vagy csak részben - értékesíti, inkább felhasználja az állatok etetéséhez. (Azaz a takarmány egyszerre lehet végső felhasználásra és értékesítésre szolgáló áru és más termelési folyamat alapanyaga is.) Ebben az esetben akár az is előfordulhat, hogy a növénytermesztési üzletágnak semmilyen értékesítési bevétele nem keletkezik, azonban teljesítményét ekkor is értékelni szükséges, hiszen hozamai beépülnek az állattenyésztési üzletágba és annak értékesítési tevékenysége során fognak implicit módon realizálódni. 
Ilyenkor a növénytermesztési üzletág hozamait előállítási költségen kell számba venni. Amikor a mezőgazdasági vállalkozások megtermelt eredményét elemezzük, akkor az összes előállított hozamot értjük ez alatt - mintha azok minden esetben teljes mértékben értékesítésre kerülnének. Még akkor is igaz ez, ha mégsem kerülne teljes egészében minden hozam értékesítésre - ebben az esetben a realizált eredmény és a megtermelt eredmény eltérnek egymástól.

A megtermelt eredmény alakulását a termelési érték és a termelési költség befolyásolják, amelyek további tényezök alakulásától is függenek. Ezek összefüggéseit mutatja be a 7.4. ábra. A megtermelt eredmény változásainak részekre bontására a 2.4-es fejezetben bemutatott láncbehelyettesítés, abszolút különbözetek vagy százalékos különbözetek módszere alkalmas.

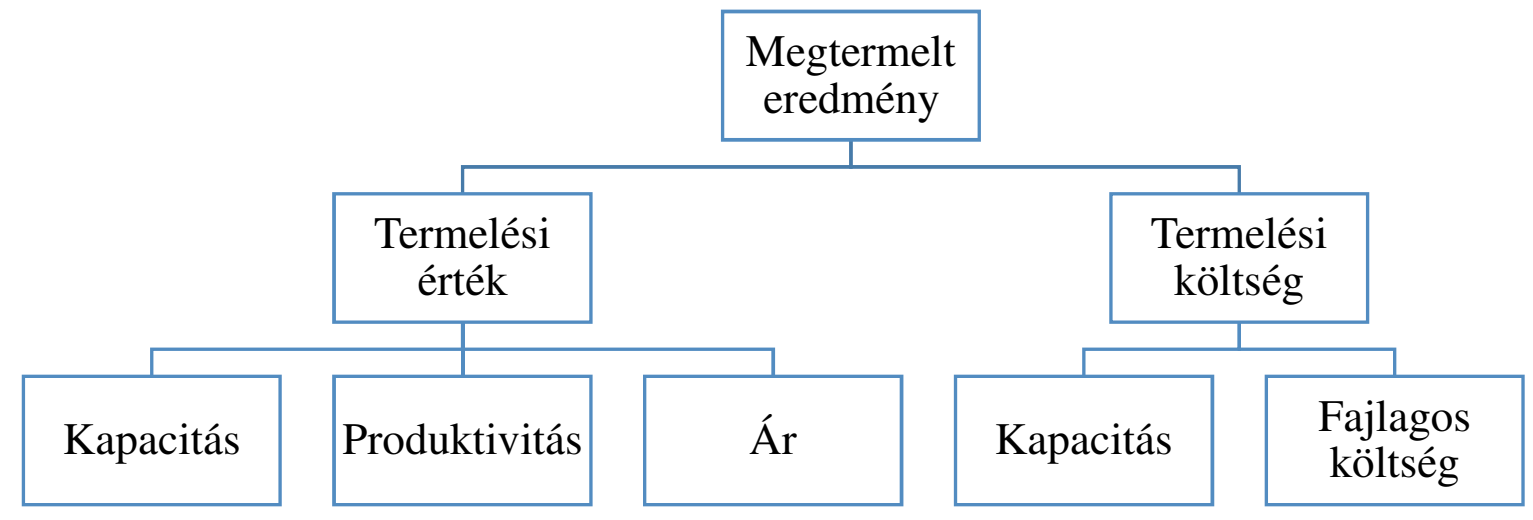

7.4. ábra A megtermelt eredményre ható tényezök

Forrás: Bíró és mtsai. (2016)

A mezőgazdasági tevékenység kiemelten fontos erőforrása a termőföld, így ennek hasznosulását mérő mutatókat szokás alkalmazni a mezőgazdaságban a korábbiakon kívül. A területegységre jutó hozamot számszerűsítő mutató számlálójában a megtermelt érték vagy hozam, nevezőjében pedig a felhasznált termőterületek mérete (hektárban) szerepel. Értéke annál kedvezőbb, minél magasabb.

$$
\frac{\text { Termelési érték vagy eredmény }}{\text { Termőföld nagysága (hektárban) }}
$$

Az egy hektáron (ha) előállított termelési értékhez kapcsolódó költségek változása szintén fontos szempont az elemzések során. Ez az ún. termelési önköltség, melynek változását a vizsgált tárgyidőszak és a bázisként használt időszak értékeinek különbsége adja.

Egy ha termelési költsége tárgyiőszakban (Ft)

Tárgyidőszak termésátlaga (t/ha)

$-\frac{\text { Egy ha termelési költsége bázisidőszakban }(\mathrm{Ft})}{\text { Bázisidőszak termésátlaga }(\mathrm{t} / \mathrm{ha})}$ 
A termelési önköltség változása a lánc-behelyettesítés módszere alapján szintén felbontható részeire: a fajlagos önköltségek változására, ill. a produktivitás (termésátlag) változására.

\section{Forrásjegyzék}

1) Béhm, I. (1998). Gazdasági-pénzügyi ismeretek. Budapest: Perfekt Gazdasági Tanácsadó, Oktató és Kiadó Zrt.

2) Bíró, T., Kresalek, P., Pucsek, J., Sztanó, I. (2016). A vállalkozások tevékenységének komplex elemzése. Budapest: Perfekt Gazdasági Tanácsadó, Oktató és Kiadó Zrt.

3) Bíró, T., Pucsek, J., Sztanó, I. (2010). Amit a mérleg mutat 2010. Budapest: Saldo Zrt.

4) Blumné Bán, E., Kresalek, P., Pucsek, J. (2011). A vállalati elemzés alapismeretei. Budapest: Saldo Zrt.

5) Sebes, J. (2013). Elemzés - Vállalati elemzés - Mérlegelemzés. Budapest: Aura Kiadó.

6) Zéman, Z., Béhm, I. (2016). A pénzügyi menedzsment controll elemzési eszköztára. Budapest: Akadémiai Kiadó. 


\section{Készletgazdálkodás}

A vállalkozás készletgazdálkodási tevékenysége logisztikai rendszerének egyik alappillére. A logisztika feladata az, hogy a vállalati termelö, szolgáltató, kiszolgáló tevékenység során biztosított legyen, hogy a megfelelő anyagok, (félkész-) termékek, eszközök a megfelelő időpontban, a megfelelő helyen, a megfelelő mennyiségben és minőségben rendelkezésre álljanak a feldolgozó-folyamatok és az értékesítési folyamatok számára. Ehhez kapcsolódva a készletgazdálkodás feladata az, hogy ezt a logisztikai folyamatot támogassa azzal, hogy biztosítja a különböző készletfajták folyamatos mennyiségi és minőségi nyilvántartását, azok rendelkezésre állását gazdaságosan és hatékonyan.

A készletek besorolása több szempont szerint is lehetséges, melyet a 8.1. táblázat foglal össze.

\section{1. táblázat Készletek fajtái}

\begin{tabular}{|c|c|}
\hline \multicolumn{2}{|c|}{ Mérleg szerinti besorolás } \\
\hline Anyagok & $\begin{array}{l}\text { Olyan készletek, amelyek értéke a termelési } \\
\text { folyamat során átmegy a késztermék vagy } \\
\text { szolgáltatás értékébe (pl. nyersanyagok, se- } \\
\text { gédanyagok, üzemanyagok, fütőanyagok, } \\
\text { fenntartási anyagok, csomagoló és irodai } \\
\text { anyagok, } 1 \text { éven belül elhasználódó eszkö- } \\
\text { zök). }\end{array}$ \\
\hline Befejezetlen termelés & $\begin{array}{l}\text { Azok a készletek, amelyeken a vállalkozás } \\
\text { már legalább egy megmunkálási folyamatot } \\
\text { végrehajtott, de jelenleg is megmunkálás } \\
\text { alatt vannak. }\end{array}$ \\
\hline Félkész termékek & $\begin{array}{l}\text { Azok a készletek, amelyeken a vállalkozás } \\
\text { már legalább egy megmunkálási folyamatot } \\
\text { végrehajtott, éppen nincsenek megmunkálás } \\
\text { alatt, de nem is késztermékek, raktáron van- } \\
\text { nak. }\end{array}$ \\
\hline Növendék és hízóállatok & $\begin{array}{l}\text { A termelési folyamatban majd később részt- } \\
\text { vevő (leválasztható terméket még nem adó), } \\
\text { a tartás során egyelöre csupán gyarapodó ál- } \\
\text { latok. }\end{array}$ \\
\hline Késztermékek & $\begin{array}{l}\text { A teljes megmunkálási folyamaton túljutott } \\
\text { készletek, amelyek értékesíthető formában } \\
\text { vannak raktáron. }\end{array}$ \\
\hline Áruk & $\begin{array}{l}\text { Azok a termékek és szolgáltatások, amelye- } \\
\text { ket a vállalkozás megvásárlást követően vál- } \\
\text { tozatlan formában tovább értékesít (pl. ke- } \\
\text { reskedelmi áruk, betétdíjas göngyölegek, } \\
\text { közvetített szolgáltatások). }\end{array}$ \\
\hline
\end{tabular}




\begin{tabular}{|l|l|}
\hline Készletre adott elölegek & $\begin{array}{l}\text { Az anyag és áruszállítóknak már átutalt, de } \\
\text { egyelöre ellentételezés nélküli készletkate- } \\
\text { gória - valójában nem fizikai értelemben } \\
\text { vett készlet, hanem elszámolási kategória, } \\
\text { így a készletgazdálkodásban ezzel nem fog- } \\
\text { lalkozunk. }\end{array}$ \\
\hline Vásárolt készletek & $\begin{array}{l}\text { Eredet szerinti besorolás } \\
\text { általa továbbértékesítési vagy felhasználási } \\
\text { célból vásárolt készletek. }\end{array}$ \\
\hline Saját termelésű készletek & $\begin{array}{l}\text { A vállalkozás üzleti folyamatai során elöál- } \\
\text { lított készletek. }\end{array}$ \\
\hline
\end{tabular}

Forrás: Éva (2011) alapján saját szerkesztés

A készletek a mérlegben a forgóeszközök közé kerülnek besorolásra, amely elnevezés utal arra a körforgásra, amelyben ezen elemek részt vesznek a vállalati értékteremtő folyamat során. Ezt szemlélteti a 8.1. ábra.

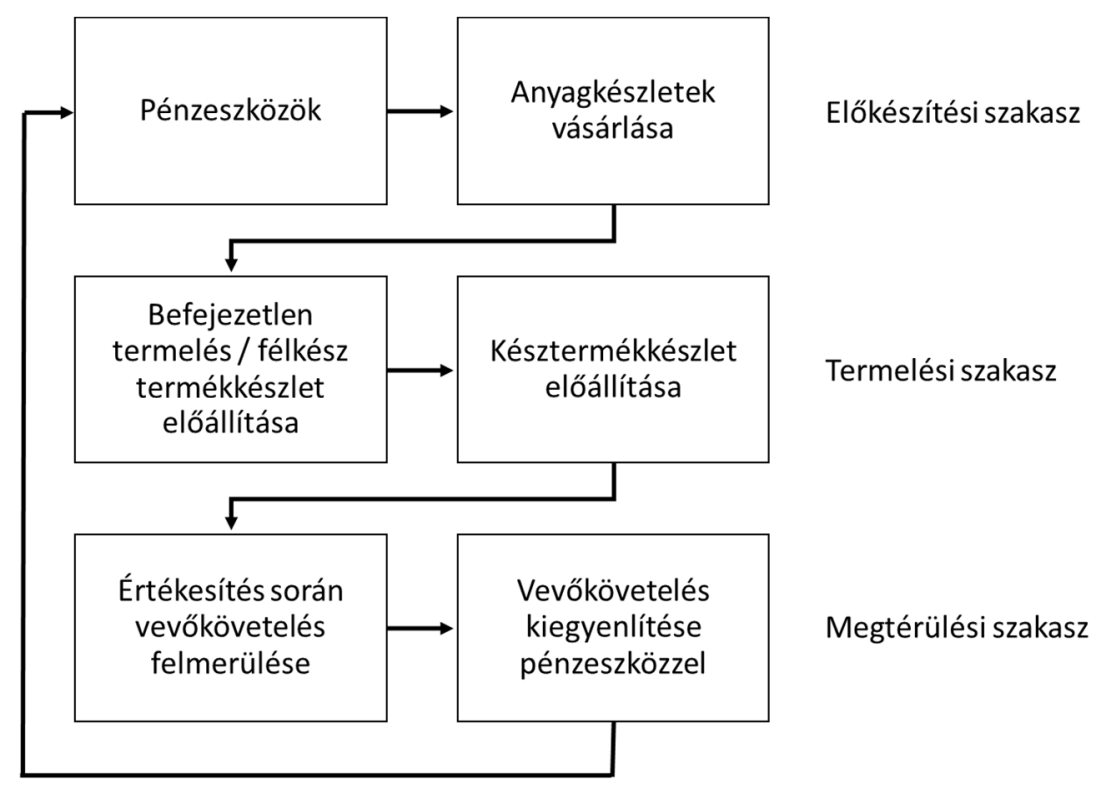

\section{1. ábra Forgóeszközök körforgása}

Forrás: Kállay - Koloszár (2015)

A készletgazdálkodás értékelése során jellemzően a készletek átlagos nagyságával számolunk, mely érték két készletellenőrzési időpont közötti időszakban a vállalkozás rendelkezésére álló készletek állományát jelenti. Ezek kiszámításához a kronologikus átlag számítást használjuk fel (lásd 2.4. fejezet).

A készletgazdálkodás elemzése során olyan területekre kell fókuszálnia a vállalkozásnak, hogy az anyagi folyamatok megfelelően képesek-e támogatni az értékteremtési folyamatokat, megfelelö-e a tartott készletek összetétele minőségi és mennyiségi szempontok szerint, mennyi 
ideig forognak a készletek a vállalaton belül, milyen mértékben képesek a készletek hozzájárulni a vállalkozás eredményéhez, vagy mik állnak a kívánt vagy nem kívánt készletváltozások hátterében.

\subsection{Anyagellátás és anyagfelhasználás elemzése}

Az anyaggazdálkodás elemzésére a termelő vállalkozások esetében van szükség, hiszen ezek azok a vállalkozások, amelyek átalakító tevékenységeket végeznek a vásárolt vagy saját előállítású anyagkészleteken annak érdekében, hogy a vevő számára értéket képviselő terméket állítsanak elő.

\subsubsection{Az anyagellátási tevékenység}

A megfelelő anyagellátás biztosítja a termelési folyamat zavartalanságát és ütemességét. Amennyiben ebben problémák lépnek fel és nem állnak rendelkezésre a szükséges anyagok, akkor abban az esetben, ha nem sikerül azonnal helyettesítő anyagokat bekapcsolni a termelési folyamatba, akkor megnövekednek a termelési állásidők, hiszen a termelésben használt berendezések és munkaerő nem képes folytatni a termelési feladatokat. Ennek megfelelően csökken a késztermékek kibocsátási volumene, romlik a felhasznált erőforrások (pl. gépek, munkaerő) kihasználtsága és termelékenysége, befejezetlen készletek halmozódnak fel. A termelési kiesés ledolgozása miatt szükséges lehet a munkavállalók túlóráztatása, mely növeli a bérköltségeket és a rezsiköltségeket. Ha a termelés kiesését nem sikerül ledolgozni, vagy csak jelentős költségek árán, akkor az a dolgozók teljesítményhez kötött keresetét is csökkentheti.

Amennyiben sikerül a termelésbe helyettesítő anyagokat bevonni, akkor rövidíthetők vagy minimalizálhatók az állásidők, ugyanakkor a helyettesítő anyagok biztosítása rendszerint többletköltségekkel (pl. szállítási költségek, beszerzési költségek, plusz megmunkálási költségek) járhat, biztosításukhoz előzetesen nem kalkulált munkaerőkapacitás-lekötésre lehet szükség, nem tökéletesen helyettesítő anyagok esetén pedig akár minőségi romlást is elszenvedhet a késztermék gyártása.

A gyártási idő mindenképpen nő akkor, ha a termeléshez szükséges anyagokat nem sikerül biztosítani, de akkor is nőhet, ha sikerül helyettesítő anyagokat alkalmazni - például a helyettesítő anyagok plusz beszerzési ideje vagy a feldolgozáshoz szükséges plusz előkészítési idő miatt.

Mindezek következtében a vevőknek történő késztermékek szállítása időbeli késedelmet vagy minőségbeli romlást - ezzel a vevői bizalom elvesztését - eredményezheti, az önköltség emelkedhet és romolhat a vállalkozás jövedelmezősége.

Az anyagellátási tevékenység elemzésekor a fenti lehetséges problémákból adódóan az állásidők és pótidők mértékét és változásait vizsgáljuk, a helyettesítőként használt anyagok termelésbe történő bevonásának hatásait, valamint az anyaghiány elkerülése okán feleslegesen felhalmozott anyagkészletek káros hatásait. 
Az állás és pótidők nagyságának alakulását vizsgálhatjuk valamely bázisidőszakhoz viszonyítva, külön figyelmet fordítva arra, hogy melyek voltak a tervezett és melyek a nem tervezett állásidők - ezek közül pedig melyiket okozta az anyagellátás hiányossága.

A túlméretezett anyagkészletek ugyan biztosítják a termelés zavartalan folytatását és az állásidők minimalizálását, ugyanakkor több területen negatívan befolyásolhatják a vállalkozás müködését. Ilyen például, hogy a vállalkozás felesleges mértékben köti le pénzügyi eszközeit, melyeket más területre befektetve nagyobb megtérülést érhetne el; megnövekedhetnek a hitelből vásárolt anyagkészletek finanszírozásából adódó kamatköltségek; felesleges raktárterületés raktári munkaerö-kapacitást köthet le, mely többletköltségekkel járhat; a nem megfelelö raktárnyilvántartás és a felhasználás nem megfelelö ütemezése esetén az anyagok szavatossági időn túl történő tárolásából veszteségek keletkezhetnek.

\subsubsection{Az anyag-felhasználási tevékenység}

Az anyagok felhasználásának elemzése történhet dinamikusan, azaz egy bázis időszak és a tárgyidőszak összehasonlításával - melyhez a fajlagos anyag-felhasználási mutatókat szokás használni (8.2. táblázat) - valamint történhet normák segítségével - amikor azt elemezzük, hogy az előzetesen megadott müszaki paraméterek által indokolt mértéktől milyen mértékben tért el a tényleges felhasználás mértéke.

\section{2. táblázat Fajlagos anyag-felhasználási mutatók}

\begin{tabular}{|l|l|}
\hline \multicolumn{1}{|c|}{ Mutató megnevezése } & Mutató \\
\hline Fajlagos anyagfelhasználás & $\frac{\text { Felhasznált anyag mennyisége }}{\text { Előállított termék mennyisége }}$ \\
\hline Anyagkihozatal & $\frac{\text { Előállított termékek mennyisége }}{\text { Felhasznált anyag mennyisége }}$ \\
\hline
\end{tabular}

A két fajlagos anyag-felhasználási mutató egymás reciproka, ennek megfelelöen értékük ellentétes irányba mozog. Míg a fajlagos anyagfelhasználás - azaz egységnyi termék előállításához szükséges anyagfelhasználás nagysága - értéke annál kedvezőbb, minél magasabb, addig az anyagkihozatal - mely az egységnyi felhasznált anyagra jutó előállított termék mennyisége - annál kedvezőbb minél magasabb.

Akkor beszélhetünk anyagmegtakarításról, ha a tárgyidőszaki fajlagos anyag-felhasználási mutató alacsonyabb, mint a bázisidőszaki. Ennek mértékét az alábbi képlettel számíthatjuk ki:

$$
\text { Anyagmegtakarítás }=\mathrm{q}_{1} \times\left(\mathrm{a}_{0}-\mathrm{a}_{1}\right)
$$

ahol:

- $\mathrm{q}_{1}=$ tárgyidőszakban előállított termékmennyiség

- $\mathrm{a}_{0}=$ bázisidőszaki fajlagos anyag-felhasználási mutató

- $\quad a_{1}$ = tárgyidőszaki fajlagos anyag-felhasználási mutató 
Az anyagmegtakarítás egyúttal anyagköltség-megtakarítással, a termelési önköltség csökkenésével, a jövedelmezőség javulásával jár és kisebb anyagkészletek tartási szükségletét is eredményezi.

A normáktól való eltérés elemzésére a termelési folyamatok lezárása után van lehetőség. Az alábbi anyag-felhasználási mutatókat különböztetjük meg:

- beszerzési norma: adott termék összes anyagszükséglete, amely beszerzésre kerül a termék gyártásához, figyelembe véve a képződő selejtet és az esetleges tárolási és szállítási anyagszükségleteket;

- bruttó anyag-felhasználási norma: ez alapján történik meg a raktárból a termék gyártásához szükséges mennyiségü anyag utalványozása, de ennek egésze nem épül be a termékbe, mivel tervezett hulladék is képződik belőle;

- nettó anyag-felhasználási norma: a termékbe ténylegesen beépülö mennyiségü anyag;

- keletkezett hulladék: a bruttó és nettó anyag-felhasználási norma különbözete;

- normaváltozás: a gyártástechnológia vagy a termékkonstrukció megváltoztatásából eredő anyagnorma változása.

Az anyag-felhasználási normák alapján kerül kiszámításra az anyagkihozatali együttható, amely azt mutatja meg, hogy a raktárból a termék gyártásához utalványozott anyagmennyiség hány százaléka épül be a termékbe ténylegesen. A fennmaradó rész a hulladék aránya a bruttó anyag-felhasználási normán belül.

$$
\begin{gathered}
\text { Anyagkihozatali együttható }=\frac{\text { Nettó anyag }- \text { felhasználási norma }}{\text { Bruttó anyag }- \text { felhasználási norma }} \times 100 \\
\text { Hulladék aránya }=100-\text { Anyagkihozatali együttható }
\end{gathered}
$$

Egy termék összes anyagfelhasználásának mértékét a teljes termelési volumen, a termék nettó anyag-felhasználási normája, a képződő hulladék és a selejtek mértéke határozza meg az alábbi képlet szerint:

Összes anyagfelhasználás

$=$ Termelési norma $\times$ Nettó norma $\times$ Hulladék mértéke $\times$ Selejt mértéke

ahol

- Hulladék mértéke $=\frac{\text { Bruttó anyag-felhasználási norma }}{\text { Nettó anyag-felhasználási norma }}$

- Selejt mértéke $=\frac{\text { Beszerzési norma }}{\text { Bruttó anyag-felhasználási norma }}$.

A termék összes anyagfelhasználásának változását befolyásoló tényezők hatását a lánc-behelyettesítés módszerével számszerüsíthetjük. 
Mindezek mellett az anyagveszteségek aránya mutató is meghatározható, amely tulajdonképpen a hulladékok, selejtek és egyéb anyagveszteségek százalékos arányát mutatja meg.

$$
\text { Anyagveszteség aránya }=\frac{(\text { Beszerzési norma }- \text { Nettó norma })}{\text { Beszerzési norma }}
$$

Szükség esetén a bemutatott számítások kiegészíthetők az anyagokhoz kapcsolódó költségelemek alakulásának vizsgálatával is.

\subsection{Készletalakulás elemzése}

Az optimális készletnagyság meghatározása nem csak azért fontos, hogy a vállalat anyagi folyamatai zökkenőmentesen haladhassanak, és az egyes munkafolyamatok számára mindig megfelelő mennyiségü készlet álljon rendelkezésre, hanem azért is, mert a készlettartásnak költségei (pl. raktározási költségek, raktári munkaerő költsége, befektetett pénzeszközök alternatív költségei, beszerzési költségek, mozgatási költségek stb.) is vannak. Ezért tulajdonképpen két szempont szerinti ellentétes irányú optimalizálást kell végrehajtani.

Egyfelől szükség van a megfelelően nagy készletekre, másfelől csökkenteni kell a készletek nagyságát, amennyire csak lehet, hogy az ehhez kapcsolódó költségek a lehető legalacsonyabbak legyenek. Annak érdekében, hogy ezt a kétirányú optimalizációt a vállalkozás sikeresen végrehajtsa, szükséges előzetes készletnormák megállapítása, amelyek a különböző készletek legmegfelelőbb mértékü mennyiségét, minőségét, összetételét határozzák meg.

A készletalakulás elemzése során első lépésben az előzetesen megállapított készletnormákhoz való viszonyítás történhet meg. Ezen kívül szokás vizsgálni a készletek összetételét, azok idöbeli alakulását, a termelés (ill. az árbevétel) és a készletek alakulásának kapcsolatát.

A fejezet során figyelmünket az anyagkészletekre, a befejezetlen termelésű készletekre, a félkész termékek készletére és a késztermékek készletére fókuszáljuk. A készletgazdálkodás kereskedelemben érvényesülő sajátosságaira pedig a 11. fejezetben még külön kitérünk.

\subsubsection{Készletnormáktól való eltérések elemzése}

A készletnormáktól való eltérés során meghatározhatóvá válnak az előzetesen tervezett készletállomány-mennyiségtől való eltérések, valamint ezek okai. Az eltéréseket készlettípusonként külön-külön szokás számba venni, és az egyes befolyásoló tényezők elkülönített hatásainak számszerüsítésére a lánc-behelyettesítéses módszer alkalmazható (8.3. táblázat). 


\section{3. táblázat Különböző típusú készletek értékének kiszámítási módjai}

\begin{tabular}{|l|r|}
\hline \multicolumn{1}{|c|}{ Készlettípus } & Mutató \\
\hline Anyagkészlet & Átlagos tárolási idő (nap) $\times$ Egy napi anyagfelhasználás $(\mathrm{Ft})$ \\
\hline $\begin{array}{l}\text { Befejezetlen terme- } \\
\text { lésű készlet }\end{array}$ & $\begin{array}{r}\text { Gyártási átfutási idő }(\mathrm{nap}) \times \text { Átlagos készültségi fok } \\
\times \text { Egy napi termelési költség (előállítási közvetlen költség, Ft) }\end{array}$ \\
\hline Késztermék készlet & $\begin{array}{r}\text { Átlagos késztermék tárolási idő (nap) } \\
\times 1 \text { napi termelési költség }(\mathrm{Ft})\end{array}$ \\
\hline
\end{tabular}

Az anyagkészletek csökkentése során az átlagos tárolási idő csökkenthető korszerü anyagellátási rendszer használatával - melynek segítségével megfelelően ütemezetten áramolhatnak az anyagok a termelési folyamatban, és az indokolatlan állásidők kiküszöbölhetők -, az elfekvő és nem hasznosítható készletek értékesítésével, a norma feletti készletek felszámolásával vagy olyan beszállítók választásával, amelyek rugalmasabban, gyorsabban és akár nagyobb rendszerességgel tudnak anyagokat szállítani. Az egy napra eső anyagok felhasználásának csökkentése értelemszerüen elérhető a napi termelési volumen csökkentésével (amely azonban nem feltétlenül lehet cél), a termelési összetétel kevésbé anyagigényes termékek irányába való eltolásával, a fajlagos anyagfelhasználás csökkentésével (pl. gyártmány- vagy gyártástechnológia-fejlesztéssel), vagy akár olcsóbb helyettesítő anyagok felhasználásával.

A befejezetlen termelés csökkenthető a gyártási átfutási idő, a gyártmány vagy a gyártástechnológia korszerüsítésével, hatékonyabb munkaszervezéssel, az anyagok munkafolyamatok közötti gyorsabb mozgatásával, jobb gyártás-előkészítéssel. Szintén e készletek csökkentéséhez járulhat hozzá a termékek egységköltségének csökkentése. A gyártási átfutási idő és az átlagos készültségi fok szorzatát gyártásfinanszírozási időnek (napokban mérve) nevezzük, amely az átlagos készültségi fok segítségével csökkenthető lenne elvileg, azonban ez egyúttal a gyártási átfutási idő meghosszabbodását is jelentené.

A késztermékek készletének csökkentésére megoldást jelenthet a folyamatosabb és gyorsabb ütemü értékesítés és kiszállítás, valamint mindazon tényezők, amelyek a befejezetlen termelésű készletek termelési költségét is csökkentik.

Természetesen mindegyik készlettípus értéke vizsgálható idősorosan, ill. egyes korábbi időszakok készletértékeihez viszonyítottan.

\subsubsection{Készletösszetétel, készlethatékonyság dinamikus elemzése}

A készletállomány struktúrájának elemzése során megoszlási viszonyszámok segítségével a pénzértékben mért egyes készlettípusok részarányát számítjuk ki a teljes készletértéken belül (8.4. táblázat). Jellemzően az a cél, hogy az anyagkészleteket viszonylagosan alacsonyan lehessen tartani a késztermékkészletekhez képest. A termelő vállalkozások esetében a saját termelésü készletek és az anyagok azok, amelyek nagyobb súllyal lehetnek jelen, míg a kereskedelmi vállalkozások esetében ugyanez a vásárolt termékekre és a késztermékekre igaz. 
8.4. táblázat Készletállományok relatív nagyságát mérő mutatók

\begin{tabular}{|l|c|}
\hline \multicolumn{1}{|c|}{ Készlettípus } & Mutató \\
\hline Anyagkészlet & $\frac{\text { Anyagkészlet értéke }}{\text { Összes készlet értéke }}$ \\
\hline Befejezetlen termelésű készlet & $\frac{\text { Befejezetlen termelésű készlet értéke }}{\text { Összes készlet értéke }}$ \\
\hline Félkésztermék-készlet & $\frac{\text { Félkésztermék - készlet értéke }}{\text { Összes készlet értéke }}$ \\
\hline Késztermékkészlet & $\frac{\text { Késztermékkészlet értéke }}{\text { Összes készlet értéke }}$ \\
\hline Saját termelésủ készletek & $\frac{\text { Saját termelésű készletek értéke }}{\text { Összes készlet értéke }}$ \\
\hline Vásárolt készletek & $\frac{\text { Vásárolt készletek értéke }}{\text { Összes készlet értéke }}$ \\
\hline
\end{tabular}

Amellett, hogy a megoszlási viszonyszámok az éppen aktuális állapotról is informatív módon tájékoztatnak, vizsgálandó a változásuk mértéke is a korábbi időszakokhoz képest.

Készlethatékonyság alatt értjük, hogy 1000 forintnyi készlettel mekkora termelési értéket képes a vállalkozás létrehozni. A mutató nevezőjében használható a teljes készletállomány kronologikus átlaga vagy csak valamely készlettípus átlagos értéke. Értelemszerúen annál kedvezőbb, minél magasabb értékü. A hatékonysági mutató a készletek csökkentésével vagy a termelési érték növelésével érhető el, amennyiben a hányados másik összetevője változatlan.

$$
\text { Készlethatékonyság }=\frac{\text { Termelési érték }}{\text { Készletek átlagos értéke }} \times 1000
$$

A készletek felhasználásának hatékonyságát vizsgálják a forgási típusú mutatók is, melyek szintén alkalmazhatóak az eddig vizsgált készlettípusok mindegyikére (8.5. táblázat).

\section{5. táblázat Készletforgási mutatók}

\begin{tabular}{|l|c|}
\hline \multicolumn{1}{|c|}{ Mutató megnevezése } & Mutató \\
\hline Készletek forgási sebessége & $\frac{\text { Értékesítés nettó árbevétele }}{\text { Készletek átlagos értéke }}$ \\
\hline Készletigényesség mutatója & $\frac{\text { Készletek átlagos értéke }}{\text { Értékesítés nettó árbevétele }}$ \\
\hline Készletek forgási ideje & $\frac{\text { Vizsgált időszak napjainak száma }}{\text { Forgási sebesség fordulatokban }}$ \\
\hline
\end{tabular}

A készlethatékonysági mutatóhoz hasonló a készletek forgási sebességének mutatója, amely fordulatokban fejezi ki azt, hogy a vizsgált időszak alatt az árbevételből hány alkalommal térült 
meg a vizsgált készlettípus (a mutató nevezőjében bármely készlettípus kronologikus átlaga szerepeltethető, a számlálóban pedig használhatóak még a termelési érték kategóriái). Értéke annál kedvezőbb, minél magasabb, mivel ilyenkor egységnyi idő alatt többször fordul meg a készletekben tartott pénzösszeg.

Ennek reciproka a készletigényesség mutatója, amely megmutatja azt, hogy egységnyi értékesítési árbevételre mekkora készletérték jut, azaz mekkora összegü készletre van szükség ekkora értékesítési árbevétel eléréséhez. Ennek értéke annál kedvezőbb, minél alacsonyabb, hiszen a cél az, hogy minél kisebb készletlekötéssel lehessen minél magasabb árbevételt elérni.

A készletek forgási ideje napokban mérve adja meg, hogy a készletek mennyi idő alatt fordulnak meg a vállalkozás értékteremtési folyamata során. Értéke annál kedvezőbb, minél kisebb, mert a vállalkozás célja az, hogy adott készlet minél kevesebb időt töltsön a vállalkozáson belül, a beléfektetett pénzösszeg minél gyorsabban szabaduljon fel. A forgási sebesség típusú mutatókról részletesebben lásd a 7. fejezetben leírtakat.

A közvetlen termelési költségek ismeretében futamidő (vagy tárolási idő) mutatók számolhatóak a vásárolt és saját termelésủ készlettípusokra. Azt számszerüsítik, hogy hány napig kerülnek tárolásra ezek a készletek (8.6. táblázat). A vállalkozás célja az, hogy minél rövidebb időtartamot öleljenek fel ezek a futamidők, azaz minél kevesebb ideig jelentsenek pénzlekötést a vállalkozás számára az érintett készletek és minél gyorsabban lehessen a vállalkozás pénzét új készletekbe fektetni.

\section{6. táblázat Vásárolt és saját termelésü készletek futamidö-mutatói}

\begin{tabular}{|l|c|}
\hline \multicolumn{1}{|c|}{ Mutató megnevezése } & \multicolumn{1}{c|}{ Mutató } \\
\hline Átlagos anyagtárolási idő & $\frac{\text { Anyagok átlagos értéke }}{\text { Egy napi közvetlen termelési költség }}$ \\
\hline $\begin{array}{l}\text { Befejezetlen termelés futam- } \\
\text { ideje }\end{array}$ & \begin{tabular}{l} 
Befejezetlen termelés és félkész termékek átlagos értéke \\
\cline { 2 - 2 } $\begin{array}{l}\text { Késztermékek átlagos táro- } \\
\text { lási ideje }\end{array}$
\end{tabular} \\
\hline
\end{tabular}

A készletek időbeli változásainak hatásait vizsgálja a készletrugalmassági mutató, melyet reagálási foknak is szokás nevezni. Szintén az értékesítési árbevételt és az átlagos készletértéket használja fel, azonban ezek százalékos változásait arányosítja egymáshoz, megadva ezzel azt, hogy az árbevétel 1\%-os változása mekkora készletváltozást igényelt. Optimális, ha a mutató értéke minél alacsonyabb, mert ebben az esetben az árbevételt úgy sikerül növelnie a vállalkozásnak, hogy ahhoz arányaiban kevésbé kell növelnie készleteit.

$$
\text { Készletrugalmassági mutató }=\frac{\text { Készletek százalékos változása }}{\text { Értékesítési árbevétel százalékos változása }}
$$


A készletek forgási sebességének (napokban kifejezve) és az egy napra jutó árbevételnek a segítségével a vállalkozásnál lekötött készletek nagyságát, ill. annak változását is vizsgálhatjuk - melyhez a lánc-behelyettesítés módszere használható. A mutató csökken, ha a napokban mért forgási idő csökken vagy csökken az egy napra jutó árbevétel. Az utóbbival elért csökkenés ugyan mérsékli a lekötött készletekben lévő tőke nagyságát és a hozzá kapcsolódó készletezési költségeket, de nem feltétlenül kívánatos. Sokkal jobb, ha a forgási idő csökkentésével sikerül csökkenteni a mutató értékét.

Lekötött készlet értéke $=$ Forgási idő napokban $\times$ Egy napra jutó árbevétel

\subsubsection{A készletek eredményre gyakorolt hatása}

A készletek eredményre gyakorolt hatását a készletek jövedelmezőségi mutatójával mérhetjük. Azt számszerüsíti, hogy 1000 Ft készlettel mekkora eredményt ért el a vállalkozás. Az eredményt a vállalkozás üzemi (üzleti) eredményének kategóriájával mérjük. A nevezőben bármely készletkategóriát szerepeltethetjük, de fontos, hogy átlagos időszaki értéket tüntessünk fel.

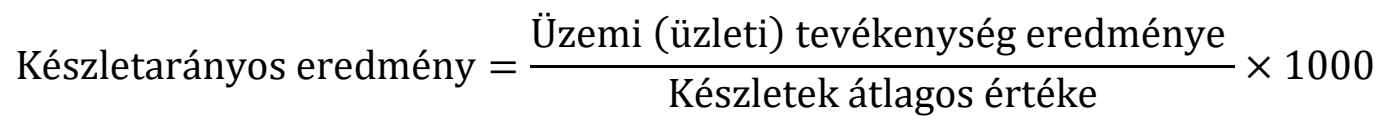

Értelemszerüen annál kedvezőbb a vállalkozás helyzete, minél magasabb a mutató értéke, amely növelhető az eredmény növelésével vagy a készletek csökkentésével.

\subsection{A minőség vizsgálata}

A készletekkel és a vevő számára értékesítendő késztermékekkel kapcsolatban fontos a vállalkozásnak figyelemmel lennie arra, hogy mit tekint a vevő minőségnek, miért hajlandó a vállalkozás termékét megvásárolni, milyen tulajdonságokat és hasznokat vár a terméktől, ill. annak megvásárlásától a fogyasztó. Ezért a vállalkozásnak folyamatosan nyomon kell követnie egyfelöl azt, hogy potenciális vevőinek mire van szüksége, milyen termékkel lehet kielégíteni az ő igényeiket, ill. a már forgalmazott termékei mennyire felelnek meg ezeknek az igényeknek és amennyiben nem, vagy csak részben felelnek meg, akkor mi ennek az oka, esetlegesen hol lehet ezen javítani. A vevőktől szerzett információkon túl a termelő vállalatnak a saját gyártási folyamatait is monitoroznia kell, hogy a gyártásból adódó hibákat, selejteket és az ebből adódó minőségi költségeket is csökkentse. A vállalkozás forgalmazott termékeinek minősége hosszú távon kihatással van a vállalkozás hírnevére, ezáltal jövedelmezőségére is.

\subsubsection{A minőség vizsgálata a vevőelégedettség szempontjából}

A vevőelégedettségi vizsgálatok során közvetlenül a vevőktől, vagy a vevővel kapcsolatba kerülő értékesítőktől, szervizektől jut fontos információkhoz a vállalkozás arról, hogy melyek 
termékének minőségi kritériumai vevői szempontból. Vizsgálni kell mindazokat a terméktulajdonságokat, amelyekkel a vevő szembesül a vásárláskor, a használatkor valamint a termék életciklusának végén az attól való megszabaduláskor.

Ezen kívül fontosak lehetnek a vevő számára az alábbiak:

- milyen gyorsan és milyen költségek árán juthat hozzá a termékhez;

- határidőre megkapja-e a terméket;

- ár-érték arányban azt a minőséget kapja-e, amelyre számított;

- a használat során felmerülnek-e esetleges javítási feladatok és költségek, ill. milyen gyorsan lehet a terméket javítani, milyen a hozzáférés a szervizhálózathoz;

- milyen színvonalú az értékesítést követő vevői utógondozás, a vevőszolgálat munkája.

Az értékesített termékekkel kapcsolatban felmerülő vevői panaszok, reklamációk, ill. termékcserék mérésére szolgáló mutatókat foglalja össze a 8.7. táblázat.

\section{7. táblázat Vevőelégedettségi mutatók}

\begin{tabular}{|c|c|}
\hline Mutató megnevezése & Mutató \\
\hline \multirow{2}{*}{ Reklamációk aránya } & Vevőreklamációval érintett termékek ( $\mathrm{db}$ vagy Ft) \\
\hline & Összes termékek (db vagy Ft) \\
\hline \multirow{2}{*}{ Kicserélt termékek aránya } & Kicserélt termékek (db vagy Ft) \\
\hline & Összes termék ( $\mathrm{db}$ vagy $\mathrm{Ft}$ ) \\
\hline
\end{tabular}

A vevői panaszokkal kapcsolatosan az ezekhez tapadó költségeket is számszerüsíteni kell, melybe beleszámoljuk a minőség miatti reklamációk költségeit, a garanciális javítási vagy csereköltségeket, a minőségi hiba miatt adott árengedményeket és kártérítéseket valamint a termékcserék költségeit. Ezeket együttesen érdemes az értékesítési nettó árbevételhez viszonyítani. A mutató értéke akkor jó, ha minél alacsonyabb.

$$
\begin{aligned}
& \text { Elégtelen minőségből adódó költségek aránya } \\
& \qquad=\frac{\text { Összes vevői panaszokkal kapcsolatos költség }}{\text { Értékesítés nettó árbevétele }}
\end{aligned}
$$

\subsubsection{A minőség vizsgálata a gyártási folyamat és a késztermékek minőségének szempontjá- ból}

A gyártás oldaláról történő minőségvizsgálat célja az, hogy a vevő már lehetőleg ne is találkozzon hibás termékkel, azok ne kerüljenek ki a gyárból, ill. minél kevesebb selejtes termék kerüljön legyártása. A selejtekkel kapcsolatos elemzés részben müszaki, részben gazdasági feladat. 
Kétféle selejtfogalmat különböztetünk meg:

- bruttó selejtkár:

○ olyan termék vagy alkatrész, amely véglegesen selejt marad (nem javítható) ennek értéke a selejt előállításának költsége

○ olyan termék vagy alkatrész, amely még javítható - ennek értéke a javítás költsége

- nettó selejtkár:

○ a bruttó selejtkár és a selejttermék vagy -alkatrész értékesítésekor kapható öszszeg különbözete

○ a bruttó selejtkár és a hibás munka miatti kártérítés összege.

A két selejtkár közül elemzési szempontból a bruttó selejtkár fontos, mivel az közömbös, hogy sikerült-e alacsonyabb áron értékesíteni a selejtet, avagy sem.

A selejtes gyártás méréséhez használatos mutatókat a 8.8. táblázat foglalja össze.

\section{8. táblázat A selejtes gyártást mérö mutatók}

\begin{tabular}{|l|c|}
\hline \multicolumn{1}{|c|}{ Mutató megnevezése } & Mutató \\
\hline Selejtarány I. & $\frac{\text { Selejtes termék mennyisége (db vagy Ft) }}{\text { Összes termékek (db vagy Ft) }}$ \\
\hline Selejtarány II. & $\frac{\text { Termék bruttó selejtkára }}{\text { Termék termelési értéke }}$ \\
\hline Átlagos selejtarány & $\frac{\text { Bruttó selejtkár }}{\text { Termelési érték }}$ \\
\hline
\end{tabular}

A selejtarány mutatók egy kiválasztott termék gyártása során keletkezett selejt arányát állapítják meg az összes, ebből a termékből legyártott darabszámhoz képest. Annál kedvezőbb, minél kisebb az értéke. Az átlagos selejtarány a termelő vállalkozás összes termékét figyelembe véve adja meg a selejt arányát.

A nem megfelelő minőségü termelésnek alternatív költsége is van, hiszen az alatt az idő alatt, amely során a selejt legyártásra került, lehetett volna tökéletes minőségü, teljes áron értékesíthető terméket is előállítani, amely azonban így elmaradt. Ezt a veszteséget számszerüsíti a kieső termelési érték mutatója.

Kieső termelési érték

= Nem megfelelő minőség miatt felhasznált órák száma

$\times 1$ órára jutó termelési érték

A gyártási folyamat minőségének értékelésére alkalmas módszer a legyártott termékek osztályozása, minőségi besorolása és ezek alapján a minőségi kategóriák alapján az átlagos minőségi kategória és az átlagos minőségi együittható meghatározása (8.9. táblázat). 
8.9. táblázat Elkészült termékek minőségét jellemzö mutatók

\begin{tabular}{|l|c|}
\hline $\begin{array}{c}\text { Mutató meg- } \\
\text { nevezése }\end{array}$ & Mutató \\
\hline $\begin{array}{l}\text { Átlagos mi- } \\
\text { nőségi kate- } \\
\text { gória }\end{array}$ & $\begin{array}{c}\text { I. oszt. termékek }(\mathrm{db}) \times 1+\text { II. oszt. termékek }(\mathrm{db}) \times 2+\text { III. oszt. terméke } \\
\begin{array}{l}\text { Átlagos mi- } \\
\text { nőségi } \\
\text { együttható }\end{array}\end{array} \quad$ Összes termékek $(\mathrm{db})$ \\
\hline
\end{tabular}

Az átlagos minőségi kategória azt méri, hogy átlagosan milyen minőségi kategóriába eső terméket képes a vállalkozás legyártani. Értéke annál kedvezőbb, minél közelebb van egyhez, amelyet azonban sohasem ér el abban az esetben, ha van valamennyi II. vagy III. osztályú termék.

Az átlagos minőségi együttható százalékban adja meg, hogy mekkora részt sikerült a vállalkozásnak előállítania abból a maximális termelési értékből, amely akkor állt volna elő, ha minden terméket I. osztályú minőségben sikerült volna legyártania. Erre is igaz, hogy sohasem éri el az 1-et, ha van II. vagy III. osztályú termék is, de cél annak közelítése.

\subsubsection{A minőség vizsgálata a minőséggel kapcsolatos költségek szempontjából}

A minőséggel kapcsolatos költségek követésére azért kell hangsúlyt fektetni, mert ezek alakulásából következtetések vonhatók le a vállalkozás termékeinek minőségére. Ezeket a költségeket három csoportba soroljuk: megelőzési költségek, minősítési költségek és hibaköltségek (8.10. táblázat). 


\begin{tabular}{|c|c|}
\hline Költségkategóriák & Tartalom \\
\hline Megelőzési költségek & $\begin{array}{l}\text { Hibamentes kibocsátás érdekében megtett } \\
\text { előzetes intézkedések költségei: } \\
\text { - } \text { vevői igények feltárása; } \\
\text { - minőség tervezése; } \\
\text { - } \text { beszállítók minősítése; } \\
\text { - minőségügyi képzés; } \\
\text { - minőségbiztosítási rendszer auditá- } \\
\text { - lása; } \\
\text { - minőségügyi jelentések készítése. }\end{array}$ \\
\hline Minősítési költségek & $\begin{array}{l}\text { Ellenörzési terv szerint végzett ellenőrzési } \\
\text { tevékenységek költségei: } \\
\text { - } \text { beérkezett anyagok, áruk ellenőr- } \\
\text { zése; } \\
\text { - } \text { ellenőrzéshez használt eszközök és } \\
\quad \text { szolgáltatások; } \\
\text { - } \text { gyártási tesztek. }\end{array}$ \\
\hline Hibaköltségek & $\begin{array}{l}\text { A minőségi követelmények nem teljesítésé- } \\
\text { böl adódó költségek: } \\
\text { _ } \text { Belső hibaköltségek: a termék kibo- } \\
\text { csátása előtt merülnek fel (selejt } \\
\text { költsége, hibaelhárítás és -javítás } \\
\text { költsége, állásidők vesztesége); } \\
\text { - } \quad \text { Külső hibaköltségek: piacra került } \\
\text { termékek költségei (garanciális költ- } \\
\text { ségek, termékcserék, reklamációk); } \\
\text { - Immateriális veszteségek: a vállalko- } \\
\text { zás presztízsének, jó hírnevének } \\
\text { romlása, a vevők bizalomvesztése, } \\
\text { piacvesztés. }\end{array}$ \\
\hline
\end{tabular}

\section{Forrásjegyzék}

1) Bán, E., Kresalek, P., Pucsek, J. (2017). A vállalati gazdálkodás elemzése. Budapest: Perfekt Zrt.

2) Birher, I., Pucsek, J., Sándor, L., Sztanó, I. (2009). A vállalkozások tevékenységének gazdasági elemzése. Budapest: Perfekt Zrt.

3) Blumné Bán, E., Kresalek, P., Pucsek, J. (2011). A vállalati elemzés alapismeretei. Budapest: Saldo Zrt.

4) Éva, K. (2011). Számvitel-elemzés I. Perfekt Zrt. 
5) Himber, P., Kapásiné Buza, M., Kovácsné Soós, P. (2011). Számvitelelemzés II. Budapest: Perfekt Gazdasági Tanácsadó, Oktató és Kiadó Zrt.

6) Kállay, B. (2012). Forgóeszközgazdálkodás. In Juhász, L. Vállalati erőforrás-gazdálkodás. Sopron: Nyugat-magyarországi Egyetem Kiadó.

7) Kállay, B., Koloszár, L. (2015). Az üzleti diagnosztika alapjai. Sopron: Nyugat-magyarországi Egyetem Kiadó.

8) Sebes, J. (2013). Elemzés - Vállalati elemzés - Mérlegelemzés. Budapest: Aura Kiadó.

9) Zéman, Z., Béhm, I. (2016). A pénzügyi menedzsment controll elemzési eszköztára. Budapest: Akadémiai Kiadó. 


\section{Tárgyieszköz-gazdálkodás}

A vállalkozási tevékenység elemzésének egyik fontos területe a tárgyi eszközökkel történő gazdálkodás eredményességének, hatékonyságának vizsgálata. Ide tartoznak mindazon eszközök, amelyek hosszú távon a vállalkozás tevékenységének szolgálatában állnak (1 évnél hoszszabb időtartamban), segítségükkel történik meg az új termékek előállítása és értékük a termelési folyamat révén, hosszú távon, folyamatosan, az elhasználódásukkal párhuzamosan megy át a késztermékek, illetve a velük végzett szolgáltatások értékébe.

A tárgyi eszközökkel való gazdálkodás tevékenységének fontos eleme, hogy a vállalkozás képes legyen meghatározni a termeléséhez szükséges tárgyi eszköz-állomány optimális szintjét, figyelembe véve a tárgyi eszközök várható élettartamát, azok kapacitását (az elöállítható termékek mennyiségét), az eszközök gazdaságos működtetését, beruházási, karbantartási és üzemeltetési költségeiket, valamint azok élettartamának végén jelentkező maradványértéket.

A tárgyi eszközök beszerzésekor azok müszaki állapota 100\%-osnak tekinthető, amely azonban a használat során folyamatosan csökken. Kétféle avulásról is beszélünk ezzel kapcsolatban. A fizikai avulás tulajdonképpen a müszaki állapot objektíven észrevehető romlását jelenti. Az erkölcsi avulás pedig az ágazati technológia fejlődése miatt sújtja a vállalkozást, hiszen korábban beszerzett gépei a technológia fejlődésével kevésbé minősülnek korszerünek, esetleg az aktuálisan legfrissebb technológiához képest kisebb volumenben képesek termelni, magasabb költségek mellett képesek a termékeket előállítani stb. Mindkét avulást figyelembe véve kell a vállalkozásnak döntést hoznia arról, hogy a birtokában lévő tárgyi eszközöket mennyi ideig használja: mikor jön el az az idő, amikor már nem minősíthető gazdaságosnak használatuk és selejteznie kell őket. A fizikai avulás késleltethető, ha a vállalkozás megfelelő figyelmet fordít eszközei karbantartására, amely természetesen költségekkel is jár számára. Jellemzően a tárgyi eszközök fizikai avulás szempontjai szerinti élettartama hosszabb, mint az erkölcsi avulást is figyelembe vevő élettartam.

A tárgyi eszközök beszerzéskori értékét bruttó értéknek nevezzük, míg az elavultságának fokával csökkentett értékét nettó értéknek. Az avulás mértékét az értékcsökkenési leírás (vagy más néven amortizáció) jelzi a vállalkozás beszámolóiban, amely lehet lineáris, degresszív, progresszív vagy kombinált is (a vállalat üzletpolitikájától és a tárgyi eszközök jellegétől függően).

A tárgyi eszközök besorolása lehetséges a mérleg alapján, a vállalkozás tevékenységében betöltött feladatuk alapján, ill. használatbavételük alapján (9.1. táblázat). 


\section{1. táblázat Tárgyi eszközök fajtái}

\begin{tabular}{|c|c|}
\hline \multicolumn{2}{|c|}{ Mérleg szerinti besorolás } \\
\hline Ingatlanok & $\begin{array}{l}\text { Termőföldek, erdők, telkek, épületek és } \\
\text { épületrészek, egyéb építmények. }\end{array}$ \\
\hline Müszaki berendezések, gépek, jármüvek & $\begin{array}{l}\text { Termelő gépek és berendezések, szerszá- } \\
\text { mok, gyártóeszközök, számítástechnikai } \\
\text { eszközök, termelésben közvetlenül részt } \\
\text { vevő járművek. }\end{array}$ \\
\hline $\begin{array}{l}\text { Egyéb berendezések, felszerelések, jármü- } \\
\text { vek }\end{array}$ & $\begin{array}{l}\text { A vállalkozási tevékenységet közvetett mó- } \\
\text { don szolgáló üzemi (üzleti) gépek és beren- } \\
\text { dezések, egyéb jármúvek, irodai felszerelé- } \\
\text { sek és berendezések. }\end{array}$ \\
\hline Tenyészállatok & $\begin{array}{l}\text { A termelési folyamatban már résztvevő (le- } \\
\text { választható terméket adó), a tartás költségei } \\
\text { megtérülnek a leválasztható termékek érté- } \\
\text { kesítéséből. }\end{array}$ \\
\hline Beruházások, felújítások & $\begin{array}{l}\text { Egyrészt a már meglévő tárgyi eszközök ál- } \\
\text { lományának mennyiségét vagy bekerülési } \\
\text { értékét növelö eszközbeszerzések, másrészt } \\
\text { az elhasználódó eszközök élettartamát nö- } \\
\text { velő, ill. korszerúsítő tevékenységek. }\end{array}$ \\
\hline Beruházásokra adott előlegek & $\begin{array}{l}\text { A szállítóknak már átutalt, de egyelőre el- } \\
\text { lentételezés nélküli kategória - valójában } \\
\text { még fizikailag nem megvalósult beruházá- } \\
\text { sok elszámolási kategóriája. }\end{array}$ \\
\hline Tárgyi eszközök értékhelyesbítése & $\begin{array}{l}\text { Azon tárgyi eszközökre alkalmazott elszá- } \\
\text { molási kategória, amelyeknél a piaci érték } \\
\text { jelentősen különbözik a könyv szerinti ér- } \\
\text { téktől. }\end{array}$ \\
\hline \multicolumn{2}{|c|}{ Feladatok szerinti besorolás } \\
\hline Termelési eszközök & $\begin{array}{l}\text { Más termékek elöállítására szolgáló eszkö- } \\
\text { zök. }\end{array}$ \\
\hline Üzemi (üzleti) eszközök & $\begin{array}{l}\text { Olyan eszközök, melyek a vállalkozás üze- } \\
\text { mében vagy üzleti tevékenységének lebo- } \\
\text { nyolítása érdekében kerülnek felhasználásra. }\end{array}$ \\
\hline Igazgatási eszközök & $\begin{array}{l}\text { A vállalkozás irányításához, vezetési funk- } \\
\text { cióinak ellátásához szükséges eszközök } \\
\text { köre. }\end{array}$ \\
\hline
\end{tabular}




\begin{tabular}{|l|l|}
\hline Egyéb szociális, jóléti eszközök & $\begin{array}{l}\text { Olyan eszközök, melyek nincsenek kapcso- } \\
\text { latban a vállalkozás tevékenységi profiljával } \\
\text { (pl. vállalati üdülö, képzömüvészeti alkotá- } \\
\text { sok). }\end{array}$ \\
\hline \multicolumn{2}{|c|}{ Használatbevétel szerinti besorolás } \\
\hline Használatba vett eszközök & $\begin{array}{l}\text { Az üzembe helyezett, ill. használatba vett } \\
\text { eszközök köre. }\end{array}$ \\
\hline Használaton kívüli eszközök & $\begin{array}{l}\text { A még üzembe nem helyezett, vagy már } \\
\text { üzemböl kivont eszközök köre. }\end{array}$ \\
\hline
\end{tabular}

Bármely csoportosítást is vesszük figyelembe, fontos az, hogy az elemzési célnak megfelelő felosztást alkalmazzunk. A továbbiakban a mérleg szerinti kategóriák közül csak az ingatlanokkal, müszaki berendezésekkel, gépekkel, jármüvekkel és egyéb berendezésekkel, felszerelésekkel foglalkozunk.

A tárgyi eszköz-gazdálkodás elemzése során az elemzési tevékenység az eszközállomány öszszetételére, az eszközállomány állagának és használhatóságának elemzésére, ill. a kapacitáskihasználtságra terjedhet ki. Az ehhez szükséges adatokat vállalati analitikákból, főkönyvekböl, beszámolókból és teljesítmény-kimutatásokból nyerhetjük. Ágazattól függően lehetnek speciális területei (pl. mezőgazdaság), jelen fejezetben a termelő vállalatokra fókuszálunk, míg a kereskedelmi vállalkozások esetében felmerülő sajátosságokat a 11. fejezetben ismertetjük.

\subsection{Tárgyi eszközök összetételének és használhatóságának vizsgálata}

A 9.2. táblázatban bemutatott kategóriák alapján megoszlási viszonyszámokkal vizsgálható a tárgyi eszközök állományának összetétele. Fontos lehet, hogy adott időpontban egymáshoz képest mekkora súllyal szerepelnek az egyes eszköztípusok az összes tárgyi eszközön belül, de még fontosabb lehet, hogy milyen az összetétel az iparági átlaghoz képest, ill. időben, több időszakon keresztül vizsgálva milyen változások történtek a belső arányokban. A változások időbeliségének alakulása mögött meghúzódó okok feltárására is szükség van. A változásokat bruttó és nettó értéken is elemezhetjük, sőt a tárgyi eszközök értékcsökkenése alapján is. A tárgyi eszközök struktúramutatóit a 4. fejezet foglalja össze.

Az ún. hányadmutatók a struktúramutatókhoz nagyon hasonlóak, csak abban térnek el, hogy nevezőjükben nem az összes tárgyi eszköz kerül bemutatásra, hanem csak az aktivált, már rendeltetésszerüen használatba vett tárgyi eszközök (azaz a beruházások nem) (9.2 táblázat). Itt kell megemlíteni, hogy külön érdemes lehet számszerüsíteni a vizsgált időszakban újonnan aktivált eszközök arányát, azaz azon tárgyi eszközökét, amelyeket a vállalkozás rendeltetésüknek megfelelően használatba vett. 


\begin{tabular}{|l|l|}
\hline \multicolumn{1}{|c|}{ Mutató megnevezése } & Mutató \\
\hline Ingatlanhányad & $\frac{\text { Ingatlanok }}{\text { Aktivált tárgyi eszközök }}$ \\
\hline Géphányad & $\frac{\text { Gépek }}{\text { Aktivált tárgyi eszközök }}$ \\
\hline Járműhányad & $\frac{\text { Jármúvek }}{\text { Aktivált tárgyi eszközök }}$ \\
\hline
\end{tabular}

Általánosságban az mondható el, hogy a termelő tevékenységet végző vállalatoknál a termelő gépek és berendezések vannak jelen nagyobb arányban, míg például a szállító tevékenységet végző vállalatoknál a jármüvek.

Önmagukban az összetétel mutatói azonban nem elegendőek a tárgyi eszközök struktúrájának elemzésére, ugyanis az sem mindegy, hogy ezek az eszközök milyen állapotban vannak, milyen mértékben elhasználódottak, mekkora a valós nettó értékük.

A tárgyi eszközök állagára vonatkozóan a használhatósági fok mutatót számszerüsítjük, mely azt mutatja meg, hogy a tárgyi eszközök még milyen mértékben használhatóak. Célszerủ ennek számítása eszközcsoportonként külön-külön, valamint célszerü ezek tendenciáját is vizsgálni. Természetesen annál kedvezőbb a helyzet, minél nagyobb arányú ez a mutató, és semmiképpen sem kedvező, ha folyamatosan csökkenő trendet mutat - ugyanis ez az eszközök nem megfelelő pótlása melletti elhasználódására utal.

$$
\text { Használhatósági fok }=\frac{\text { Tárgyi eszközök könyv szerinti értéke (nettó) }}{\text { Tárgyi eszközök bruttó értéke }} \times 100
$$

A használhatóság számszerüsítését követően az elhasználódás mértékét is könnyü számszerüsíteni.

$$
\text { Elhasználódottsági (leírtsági) fok = } 100 \text { - Használhatósági fok }
$$

Tulajdonképpen az előző mutató jelentéstartalmával megegyezik a tárgyi eszközök leírtságának mutatója, amely a halmozott értékcsökkenés felöl mutatja be a vállalkozás tulajdonában lévő tárgyi eszközök állapotát. Annál kedvezőbb az értéke, minél közelebbi nullához, ha pedig túlzottan növekvő tendenciát mutat, akkor az a jövőben megnövekedő karbantartási és szervizelési költségeket, valamint akár a selejtarány romlását is eredményezheti a vállalkozás számára.

$$
\text { Tárgyi eszközök leírtsága }=\frac{\text { Tárgyi eszközök halmozott értékcsökkenése }}{\text { Tárgyi eszközök bruttó értéke }} \times 100
$$


A tárgyi eszközök értékcsökkenési leírását is magukban foglaló mutatók esetében fontos megjegyezni azt, hogy alakulásukat alapvetően meghatározza a vállalkozás számviteli politikája, amelyben meghatározásra kerül, hogy miként is értékeli a vállalkozás a tulajdonában lévő eszközöket, milyen értékcsökkenés-leírási módszert használ, ill. miként határozza meg eszközeinek várható hasznos élettartamát.

A használhatósággal kapcsolatban hasznos információ lehet az egyes tárgyi eszközök életkorának vizsgálata, ill. a tárgyi eszközök (vagy azok egyes csoportjainak) átlagos életkora, valamint a teljesen nullára írt eszközök aránya.

A tárgyi eszközök pótlási tevékenységével kapcsolatban számolandó a megújítási aránymutató, amely az aktivált beruházások és a tárgyi eszközök arányát mutatja be. Magas értéke mellett a vállalkozás komoly befektetéseket eszközöl jövőbeni termelésébe, feltehetően arra számítva, hogy azokhoz pozitív kilátások kapcsolódnak. Még pontosabb képet kapunk akkor, ha az újonnan aktivált eszközök értékét csak az összes aktivált eszköz értékéhez viszonyítjuk (9.3. táblázat).

\section{3. táblázat Tárgyi eszközök megújítási arányának mutatói}

\begin{tabular}{|l|l|}
\hline \multicolumn{1}{|c|}{ Mutató megnevezése } & Mutató \\
\hline Tárgyi eszközök megújítása & $\frac{\text { Tárgyév során aktivált tárgyi eszközök értéke }}{\text { Tárgyi eszközök bruttó értéke }} \times 100$ \\
\hline $\begin{array}{l}\text { Aktivált tárgyi eszközök meg- } \\
\text { újítása }\end{array}$ & $\frac{\text { Tárgyév során aktivált tárgyi eszközök értéke }}{\text { Aktivált tárgyi eszközök bruttó értéke }} \times 100$ \\
\hline
\end{tabular}

Azt tekintjük kedvezőnek, ha a megújítási mutatók alakulásának tendenciája növekvő, azaz a régi eszközöket folyamatosan újak váltják fel. Évi 10-30\%-os arány komoly fejlesztést jelez már.

A vállalkozás eszközeinek megújításával kapcsolatban nem csak a már aktivált eszközök aránya az egyetlen szempont, amit figyelembe kell venni. A folyamatban lévő beruházások mértékét szintén számításba kell venni, hiszen előfordulhat, hogy a vállalkozásnak még nem sikerült aktiválnia, ill. befejeznie a beruházást, de ugyanakkor mégis jelentős mértékủ eszközpótlásba kezdett bele, ami a jövőbeni kilátásokat illetően perspektivikus lehet.

$$
\begin{aligned}
& \text { Folyamatban lévő beruházások aránya } \\
& \qquad=\frac{\text { Folyamatban lévő beruházások tárgyévi összege }}{\text { Befejezett beruházások tárgyévi összege }}
\end{aligned}
$$

A tárgyi eszközök állományának megújítási intenzitását jellemezhetjük az eszköz-utánpótlási mutatóval, amihez a tárgyi eszközök tárgyévi értékcsökkenési leírásának mértékét kell felhasználni. 
Tárgyi eszközök utánpótlási mutatója

$$
=\frac{\text { Tárgyi eszközök tárgyévben elszámolt értékcsökkenési leírása }}{\text { Tárgyi eszközök bruttó értéke }} \times 100
$$

\subsection{Tárgyi eszközök kapacitáskihasználtsága és kapcsolódó költségei}

A tárgyi eszközök kapacitáskihasználtságának vizsgálata történhet műszaki és gazdasági megközelítésből is. Míg elöbbi egy elméleti teljesítőképességhez viszonyítja a termelési volument, addig utóbbi azt vizsgálja, hogy a kapacitások kihasználásának mekkora hatása van a vállalkozás jövedelemtermelési képességére, valamint miként hat a költségeire. Azért kell a kettőt együtt vizsgálni, mert pusztán az, ha a vállalkozás gépei műszaki kapacitásuk maximumán termelnek, nem jelent garanciát arra nézve, hogy ez a mértékü termelés nem jár irreálisan magas költségekkel és ezáltal nem hat negatívan a jövedelmezöségre.

A korábbi fejezetekben már ismertetett hatékonysági, forgási sebesség és rugalmassági mutatók a tárgyi eszközök esetében is értelmezhetők, egyúttal a kapacitáskihasználtság egyfajta mutatóinak tekinthetőek ezek is - bár a müszaki és gazdasági kapacitáskihasználtság alatt nem ezeket értjük (lásd 7.2. és 7.3.2.2. fejezetek, ill. 9.4. táblázat).

\section{4. táblázat Tárgyi eszközök hatékonysági és rugalmassági mutatói}

\begin{tabular}{|l|c|}
\hline \multicolumn{1}{|c|}{$\begin{array}{c}\text { Mutató megneve- } \\
\text { zése }\end{array}$} & Mutató \\
\hline $\begin{array}{l}\text { Főtevékenységhez } \\
\text { használt tárgyi esz- } \\
\text { közök hatékonysága }\end{array}$ & Főtevékenység termelési értéke \\
\hline $\begin{array}{l}\text { Tárgyi eszközök ru- } \\
\text { galmassága }\end{array}$ & $\frac{\text { Tárgyi eszközök százalékos változása }}{\text { Termelési érték százalékos változása }}$ \\
\hline
\end{tabular}

A korábbi fejezetekben bemutatott mutatók magyarázatára itt nem térünk ki, csupán a 9.4. táblázatban találhatókra.

A tárgyi eszközök hatékonysági mutatójához (lásd 7.3.2.2.-es fejezet) hasonlóan csupán a fötevékenységre is kalkulálható hatékonysági érték a termelési érték kategóriák bármelyikének felhasználásával. (Itt fontos megjegyezni, hogy a tárgyi eszközök hatékonysági mutatói esetében vetítési alapként a bruttó érték is használható, ha az amortizációs politika okán a tárgyi eszközök nettó értéke nincsen szoros kapcsolatban a teljesítőképességükkel).

A tárgyi eszközök rugalmasságának mutatója azt mutatja meg, hogy a termelési érték 1\%os változása mellett, mekkora mértékü változás történt a tárgyi eszközök állományában. A mu- 
tatót érdemes a tárgyi eszközök különböző csoportjaira külön-külön is kiszámítani, ezzel nyilvánvalóvá válhat, hogy melyik eszközcsoport az, amely a legnagyobb mértékben reagál a termelési érték változására.

\subsubsection{A műszaki kapacitáskihasználtság értékelése}

A müszaki kapacitások maximumán a vállalkozás tulajdonában lévő és egyébként müködő berendezéseinek elméleti teljesítőképességét értjük. Ennek elérése a gyakorlatban lehetetlen, de törekedni kell a megközelítésére. A törekvések mozgatórugói között kell megemlíteni, hogy a vállalkozás tőkéjének jelentős része kerül lekötésre ezekben az eszközökben, amelyek lehetöség szerint minél hamarabb meg kell, hogy térüljenek. Emellett a folyamatos technológiai fejlődés gyorsítja az eszközök erkölcsi avulását, ami arra ösztönöz, hogy amíg lehet, addig gazdaságosan a lehető legnagyobb mértékben legyenek kihasználva a gépek, ugyanis ha már elavultak, akkor további használatuk inkább versenyhátrányt jelent a vállalkozás számára. Emellett a kihasználatlan kapacitások ún. passzív költségeket - a tárgyi eszközökhöz kapcsolódó fix költségek, mint az értékcsökkenés vagy a karbantartás - eredményeznek, amelyek rontják a vállalkozás eredményét, ráadásul a növekvő termelési volumennel nem arányosan növekednek a tárgyi eszközök költségei, amelyek relatív költségmegtakarítást is jelentenek.

A tárgyi eszközök kapacitáskihasználtságának elemzése egymással összefüggő mutatók rendszerén keresztuil vizsgálható. (9.1. ábra)

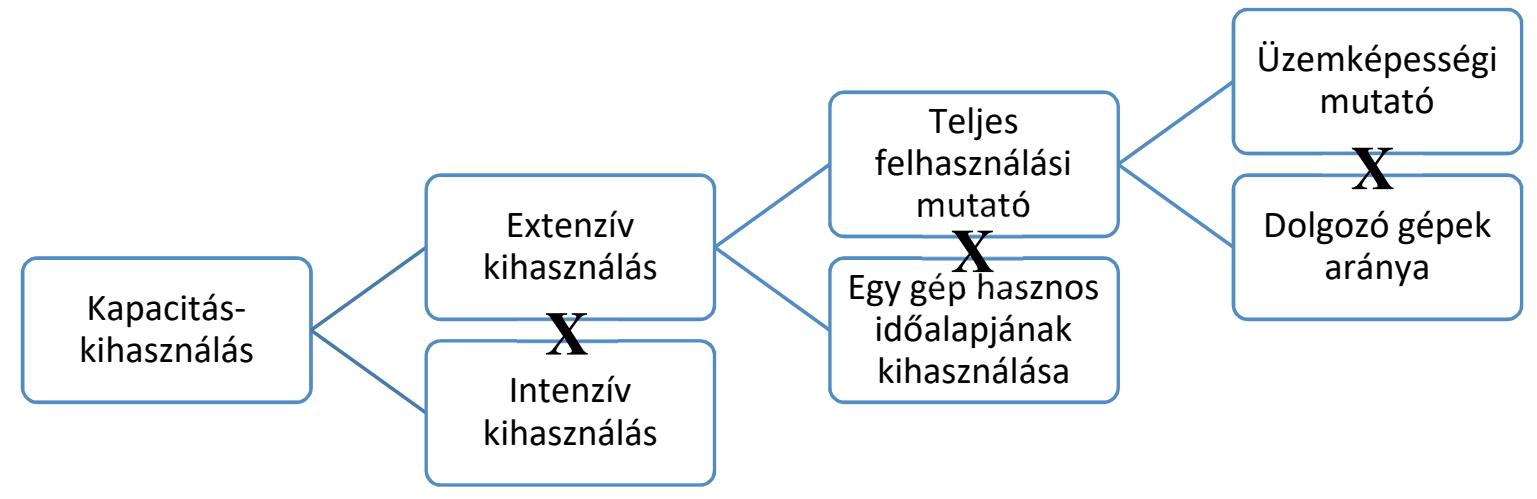

9.1. ábra A müszaki kapacitás-kihasználási mutatók rendszere

Forrás: Birher és mtsai. (2009)

A vállalkozás birtokában lévő eszközök müködési és üzemképességi aránya a teljes felhasználási mutatóban összegződik, mely további két mutatóra bontható fel (9.5. táblázat). 
9.5. táblázat Termelö berendezések felhasználásának arányai

\begin{tabular}{|c|c|}
\hline $\begin{array}{c}\text { Mutató meg- } \\
\text { nevezése }\end{array}$ & Mutató \\
\hline \multirow{2}{*}{$\begin{array}{l}\text { Üzemképes- } \\
\text { ségi mutató }\end{array}$} & Működőképes gépek, berendezések, járművek átlagos száma \\
\hline & $\begin{array}{l}\text { Rendelkezésre álló gépek, berendezések, járművek átlagos száma } \\
\qquad \times 100\end{array}$ \\
\hline \multirow{2}{*}{$\begin{array}{l}\text { Dolgozó gé- } \\
\text { pek, aránya }\end{array}$} & Működő gépek, berendezések, járművek átlagos száma \\
\hline & $\overline{\text { Működőképes gépek, berendezések, járművek átlagos száma }} \times 100$ \\
\hline \multirow{2}{*}{$\begin{array}{l}\text { Teljes felhasz- } \\
\text { nálási mutató }\end{array}$} & Működő gépek, berendezések, járművek átlagos száma \\
\hline & $\begin{array}{l}\text { Rendelkezésre álló gépek, berendezések, járművek átlagos száma } \\
\qquad \times 100\end{array}$ \\
\hline $\begin{array}{l}\text { Teljes felhasz- } \\
\text { nálási mutató }\end{array}$ & $\begin{array}{l}\text { Üzemképességi mutató } \\
\qquad \times \text { Működő gépek, berendezések, járművek aránya }\end{array}$ \\
\hline
\end{tabular}

Az üzemképességi mutató azon tárgyi eszközök arányát mutatja be, amelyek müködnek vagy müködhetnének a vállalkozás rendelkezésére álló tárgyi eszközei közül. A dolgozó gépek kategóriája ennél szűkebb és arányukat az üzemképes eszközökhöz, ill. az összes rendelkezésre álló eszközhöz is viszonyíthatjuk. Vegyük észre, hogy a teljes felhasználási mutató kétféle módon is használható, ill. integrálja magában az üzemképességi mutatót és a dolgozó gépek aránya mutatót.

A mutatók számíthatók eszközcsoportokra felbontottan is. Természetesen a cél az, hogy a vállalkozás esetében a mutatók 100\% körüliek legyenek, és amennyiben ettöl elmaradás van, akkor annak okainak feltárása fontos elemzési feladat, hiszen a korábban már említett passzív költségek a nem müködő, ill. üzemképtelen eszközök esetében is jelentkeznek.

A teljes felhasználási mutatóban számításba vett, rendelkezésre álló gépek által teljesíthető termelési időtartamot és az ebből ténylegesen megvalósuló termelésre fordított idő arányát számszerűsítjük a hasznos időalap kihasználásának mutatójával (9.6. táblázat).

\section{6. táblázat Az időalap kihasználásának vizsgálati mutatói}

\begin{tabular}{|l|c|}
\hline \multicolumn{1}{|c|}{ Mutató megnevezése } & Mutató \\
\hline $\begin{array}{l}\text { Gépek naptári hasznos } \\
\text { időalapja }\end{array}$ & $\begin{array}{r}{[(365 \text { nap } \times 3 \text { műszak } \times 8 \text { óra })-\text { karbantartási, javítási idő] }} \\
\times \text { Rendelkezésre álló gépek száma }\end{array}$ \\
\hline $\begin{array}{l}\text { Hasznos időalap kihasz- } \\
\text { nálása (extenzív kihasz- } \\
\text { nálás) }\end{array}$ & $\begin{array}{l}\text { Termelésre fordított órák száma } \\
\text { Gépek naptári hasznos időalapja }\end{array}$ \\
\hline
\end{tabular}

A hasznos időalap kiszámításakor a bemutatott képletben feltételeztük, hogy az év összes napján müködhetnek a gépek, három müszakban, müszakonként 8 óra munkaidővel. Természetesen ennek 100\%-ban történő kihasználása még a karbantartási és javítási idők levonásával is 
szinte lehetetlen (pl. az átállási idők miatt), de elméleti alapnak megfelelő feltételezésként szolgál. Az, hogy milyen mértékben sikerül ezt kihasználni, függ a tényleges munkarendtől, a vállalkozás által alkalmazott müszakszámtól, a leállásoktól és az egyéb kieső időktől.

A teljes kapacitás-kihasználtságot a rendelkezésre álló gépórák kihasználtságán kívül az ún. intenzív kihasználás befolyásolja, amely a gépekhez előzetesen meghatározott kapacitásnormák (előzetesen elvártan egy óra alatt legyártandó termékek mennyisége) teljesítését hivatott vizsgálni. A kapacitásnorma meghatározásakor azt meg kell jegyezni, hogy kiindulási alapjául a munkanorma szolgál, amely átlagos körülmények között az adott gépen elkészíthető termékek mennyiségét határozza meg, amely azonban optimális feltételek mellett mindenképpen felülmúlható, azaz a kapacitásnorma magasabb, mint a munkanorma. A maximális teljesítményszázalék érték lesz az, amely meghatározza, hogy optimális körülmények között mennyivel lehet felülmúlni a munkanorma elvárásait.

Kapacitásnorma $=$ Munkanorma $\times$ Maximális teljesítményszázalék

$$
\begin{aligned}
& \text { Kapacitásnorma teljesítése (intenzív kihasználás) } \\
& \qquad=\frac{\text { Egy órára jutó tényleges fajlagos teljesítmény (db/óra) }}{\text { Kapacitásnorma (db/óra) }}
\end{aligned}
$$

A mutató alakulását a munkafolyamatok szervezettsége, a munkavállalók feladatvégzésének hatékonysága és szaktudása befolyásolhatja.

Mivel a kapacitáskihasználtság képletét általánosságban a termelés és a kapacitások hányadosaként fogalmazhatjuk meg, ezért tulajdonképpen, ha a termelést a termelésre fordított idő és az egy órányi teljesítmény szorzataként, míg a kapacitást az elméletileg a vállalkozás rendelkezésére álló gépóra-idő és a kapacitásnormák szorzataként határozzuk meg, akkor az intenzív és extenzív kihasználtság szorzatához jutunk.

$$
\begin{gathered}
\text { Kapacitáskihasználtság }(\%)=\frac{\text { Termelés }}{\text { Kapacitás }}= \\
=\frac{\text { Termelésre fordított idő (óra) } \times \text { Egy órára jutó teljesítmény }(\mathrm{db} / \text { óra })}{\text { Elméleti időalap (óra }) \times \text { Kapacitásnorma }(\mathrm{db} / \text { óra })}= \\
=\text { Időalap kihasználása (extenzív) } \times \text { Kapacitásnorma teljesítése (intenzív) }
\end{gathered}
$$

\subsubsection{A kapacitáskihasználáshoz kapcsolódó költségek és a gazdasági kapacitáskihasználás}

Általánosságban elmondhatjuk, hogy a termelési volumen növelésével nem egyenesen arányosan, hanem annál kisebb mértékben nőnek a termelési költségek (pl. karbantartási költségek, értékcsökkenési leírás, energiaköltségek), azaz a termékek önköltsége (amennyiben a gépköltséget is tartalmazza az önköltség) csökken (méretgazdaságosság). Erre relatív költségcsökkenésként is tekinthetünk, amelyet a tárgyévi gépköltség és a bázisévi gépköltség (tárgyévben teljesített volumennel korrigált értékkel) különbözeteként számíthatunk ki. Aggregáltan és egy 
termékre vetített önköltségben is kifejezhetjük. Fontos arra figyelemmel lenni, hogy ahhoz, hogy csak a kapacitáskihasználtságból adódó gépköltség-változást számszerüsítsük, az árváltozásokat ki kell küszöbölni (pl. energiaárak változása).

ahol:

$$
\text { Relatív költségcsökkenés }=\left(\mathrm{K}_{1}^{\mathrm{v}} \times \mathrm{q}_{1}\right)+\mathrm{K}_{1}^{\mathrm{f}}-\left(\mathrm{K}_{0}^{\mathrm{v}} \times \mathrm{q}_{1}\right)+\mathrm{K}_{0}^{\mathrm{f}}
$$

- $\mathrm{K}_{1}^{\mathrm{V}}$ = tárgyidőszaki változó költségek

- $\mathrm{K}_{0}^{\mathrm{v}}$ = bázisidőszaki változó költségek

- $\mathrm{K}_{1}^{\mathrm{f}}=$ tárgyidőszaki fix költségek

- $\mathrm{K}_{0}^{\mathrm{f}}=$ bázisidőszaki fix költségek

- $\mathrm{q}_{1}=$ tárgyidőszaki teljesített volumen

Az eddigiek mindenképpen indokolják a kapacitások jobb kihasználását, azonban arra is figyelemmel kell lenni, hogy a kihasználtság túlzott mértékü növelése adott esetben a gazdaságosság rovására is mehet.

Amikor a gazdasági kapacitáskihasználást elemezzük, akkor arra vagyunk kíváncsiak, hogy a kapacitások megváltozott kihasználása mennyiben befolyásolja a vállalkozás jövedelemtermelö képességét. A jövedelemtermelő képesség két irányból határozódik meg: egyrészt a termelési költségek oldaláról, másrészt a termelési érték oldaláról.

A gazdasági kapacitás-kihasználás értékelésekor egyrészt arra vagyunk kíváncsiak, hogy mekkora a különbség a tényleges eszközlekötés és a teljesítmény (termelés) oldaláról valósan igényelt eszközlekötés mértéke között, azaz mennyi a teljesítménnyel nem fedezett tárgyi eszközök állománya. Minél kisebb ez az állomány, annál kedvezőbb a vállalat helyzete, ugyanis az így lekötött tőke felesleges lekötésnek számít, megtérülésére más területen jobb lehetőség kínálkozhat.

Teljesítménnyel nem fedezett tárgyi eszközök bruttó értéke = = Tárgyi eszközök bruttó értéke - (Tárgyi eszközök bruttó értéke $\times$ Mǔszaki kapacitáskihasználási mutató)

A képletben használt kapacitáskihasználási mutató a 9.2.1-es fejezetben tárgyalt kapacitáskihasználtság mutatója.

A feleslegesen lekötött tárgyi eszköz-állományhoz kapcsolódóan felmerülő költségek az ún. üresjárati költségek. Minden esetben ennek a költségtípusnak a minimalizálása a cél. Az üresjárati költségek a tárgyi eszközök birtoklásából eredő fix költségekre vezethetők vissza, hiszen ezek (vagy ezek egy része) akkor is felmerülnek, ha az eszközök egyáltalán nem vesznek részt a termelésben vagy üzemképtelenek. (Érdemes megjegyezni, hogy ennek kalkulációja során nem az optimális körülmények közötti és maximális kapacitásokat vesszük figyelembe, hanem a vállalat tényleges munkarendje és müszakszámai révén lehetséges kapacitásokat, amely ennek megfelelően - rendszerint kisebb, mintha a maximális kapacitásokat vennénk figyelembe.) 
Üresjárati költség

= 1 órára jutó fix költség $\times$ (hasznos időalap - termelésre fordított idő)

Összefoglalásként elmondható, hogy a kapacitáskihasználást nem a maximális értékig kell növelni, hanem mindössze addig, amíg annak gazdasági haszna van, azaz a megnövekedett kapacitáskihasználásból adódó pótlólagos hozamok meghaladják a kihasználás-növeléssel együtt járó pótlólagos költségeket.

\section{Forrásjegyzék}

1) Bán, E., Kresalek, P., Pucsek, J. (2017). A vállalati gazdálkodás elemzése. Budapest: Perfekt Gazdasági Tanácsadó, Oktató és Kiadó Zrt.

2) Birher, I., Pucsek, J., Sándor, L., Sztanó, I. (2009). A vállalkozások tevékenységének gazdasági elemzése. Budapest: Perfekt Gazdasági Tanácsadó, Oktató és Kiadó Zrt.

3) Blumné Bán, E., Kresalek, P., Pucsek, J. (2011). A vállalati elemzés alapismeretei. Budapest: Saldo Zrt.

4) Himber, P., Kapásiné Buza, M., Kovácsné Soós, P. (2011). Számvitelelemzés II. Budapest: Perfekt Gazdasági Tanácsadó, Oktató és Kiadó Zrt.

5) Sebes, J. (2013). Elemzés - Vállalati elemzés - Mérlegelemzés. Budapest: Aura Kiadó.

6) Zéman, Z., Béhm, I. (2016). A pénzügyi menedzsment controll elemzési eszköztára. Budapest: Akadémiai Kiadó. 


\section{Létszám- és bérgazdálkodás}

A vállalkozás ráfordításai között az emberi erőforrásokkal kapcsolatos ráfordításoknak kiemelkedő szerepe van, különösen az élőmunkaigényes ágazatokban.

Az összköltség eljárással készülő eredménykimutatásban a személyi jellegủ ráfordások között a bérköltséget, a személyi jellegü egyéb kifizetéseket és a bérjárulékokat különítjük el. A bérköltség tervezésekor a vállalkozásoknál a szükséges létszám meghatározását követően a munkavállalóknak fizetendő bérek, juttatások tervezésére kerül sor. A munkaerőköltség ugyanis azt a ráfordítást jelenti, amennyiért a tervezett feladatok ellátásához a megfelelö mennyiségü, valamint elvárt képzettséggel és gyakorlattal rendelkező munkaerö-állományt biztosítani lehet.

\subsection{Létszámgazdálkodás}

A létszámgazdálkodás alapját a létszámterv jelenti, amelyben a vállalkozásnál meghatározzák az átlaglétszámot a fő(bb) FEOR ${ }^{5}$ csoportok szerint részletezve. A FEOR 1-4. fócsoportok jellemzően szellemi, az 5-9. főcsoportok pedig a fizikai jellegű foglalkozásokat tartalmazzák. A létszám összetételének elemzésénél megoszlási viszonyszámok segítségével ezt a két nagy csoportot különítjük el, fontos lehet azonban a 9. föcsoportba tartozók (szakképzettséget nem igénylő foglalkozások) száma és aránya is. A terv készítésekor az elsődleges cél, hogy valamennyi telephelyen, üzemben, illetve munkafolyamatnál a szükséges munkaórában rendelkezésre álljon a kompetens, megfelelő számú és összetételü, elkötelezett munkaerő.

A humánerőforrás tervezése jellemzően az alábbi részekre különíthető el:

- Helyzetelemzés

- A munkaerő-igény és a munkaerő-kínálat összevetése

- Intézkedési terv (akciótervezés)

Helyzetelemzés során a piaci környezet felmérését követően (piaci igények változása, új vagy szükülő piac, versenytársak stb.) meghatározzák a teljesítmény- és termelékenységi célokat az értékesítési lehetőségek és a stratégiai célkitűzések figyelembevételével. Ezt követően a várható értékesítési mennyiségek alapján a termékek, illetve termékcsoportok gyártáshoz szükséges létszámot számszerűsítik a kapacitásterv alapján, üzemenként és munkakörönként (munkaerő-igény előrejelzése). A célok eléréséhez szükséges létszám kijelölésekor elsődlegesen a korábbi tapasztalatokra építenek. A munkaerő kínálat bázisát a belső munkaerő kínálat adja. Optimális esetben a létszámadatok mellett a létszám összetétele is megfelelő, azaz az alkalmazottak olyan szakképzettséggel, munkatapasztalattal, valamint mindazokkal a képességekkel és készségekkel rendelkeznek, amelyek az egyes munkakörök betöltéséhez szükségesek.

\footnotetext{
${ }^{5}$ FEOR-08-Foglalkozások Egységes Osztályozási Rendszere
} 
Számolni kell azonban az esetleges változásokkal is, amelyek egy része tervezett (áthelyezés, a munkakörök összevonása vagy szétválasztása, előléptetés stb.), vagy tervezhető (pl. nyugdíjazás), a fluktuációhoz hozzájárulhat a felmondás vagy az elbocsátás, illetve a távozók helyett új munkavállalókat is felvehet a vállalkozás.

A fluktuáció vizsgálatához az alábbi mutatókat használjuk:

$$
\begin{aligned}
& \text { Belépési forgalom, } \%=\frac{\text { Belépők száma }}{\text { Átlagos állományi létszám }} * 100 \\
& \text { Kilépési forgalom, } \%=\frac{\text { Kilépők száma }}{\text { Átlagos állományi létszám }} * 100 \\
& \text { Munkaerő-forgalom, \% }=\frac{\text { Belépők }+ \text { kilépók száma }}{\text { Átlagos állományi létszám }} * 100
\end{aligned}
$$

A vállalkozási szintű fluktuáció mellett meg kell említeni az ún. belső fluktuációt is, ami az egyes telephelyek, üzemek (horizontális fluktuáció) között alakulhat ki, akár átszervezés vagy áthelyezés következtében, akár „,spontán” munkavállalói döntés eredményeként. A munkakörök közötti mozgás (vertikális fluktuáció) tipikus példája a csoport- vagy müszakvezetői kinevezés. Nem kérdés, hogy a fluktuáció többletköltséget indukál. Az új belépőkhöz toborzási, betanítási költségek, a távozókhoz pl. végkielégítés kapcsolódhat. A gyorsan számszerüsíthető költségeken túl a vállalati teljesítményre is kedvezőtlen hatást gyakorol a fluktuáció.

A munkaerő szükséglet és a rendelkezésre álló munkaerő arányát a munkaerő fedezettsége mutatóval mérhetjük:

$$
=\begin{aligned}
& \text { Munkaerö-szükséglet fedezettsége, } \%= \\
& \text { Az adott területen,szakmában,munkaköri csoportban rendelkezésre álló létszám }
\end{aligned} * 100
$$

A mutató értéke optimális esetben 100\%, ettől akár felfele, akár lefele eltérés tapasztalható, mindenképpen beavatkozás szükséges. A tervezés mellett az elemzés során is fontos a mutató vizsgálata, hiszen felesleges létszám foglalkoztatása többletköltséget jelent, a hiányzó létszám pedig termeléskiesést és/vagy költségnövekedést (túlóra) okozhat. A leírtakon túl figyelembe kell venni azt a tényt is, hogy az állományi létszámnál adott időszak alatt ténylegesen kevesebben dolgoznak:

$$
\text { Munkaerő-felhasználási mutató (A), \% }=\frac{\text { Átlagos dolgozói létszám }}{\text { Átlagos állományi létszám }} * 100
$$

A belső munkaerő kínálat mellett a külső munkaerő kínálatot is fel kell térképezni, amelynek különösen akkor van jelentősége, ha a munkaerőpiaci helyzetet a cég vonzáskörzetében egy vagy több vállalkozás erősen vagy a szomszédos országban elérhető magasabb bér elszívó hatásával kell számolni. Hiányszakmák esetén érdemes felvenni a kapcsolatot a szakképző iskolákkal is. 
Amennyiben a munkaerő-igény és munkaerő-kínálat az előrejelzések alapján egymástól eltér, az összehangolás érdekében intézkedési tervet kell készíteni. Ha viszonylag kisebb arányú munkaerő felesleget állapítunk meg, „fájdalommentes” megoldásként dönthetünk a felvétel befagyasztása mellett (természetes fogyás a nyugdíjazás, kilépés következtében). Ennél gyorsabb beavatkozást jelent a munkaidő (ideiglenes) csökkentése (akár a telephely egészére, akár egy adott egységre vonatkozóan), illetve egy komoly piacvesztést vagy automatizálást követően a drasztikusabb létszámleépítés. Átmeneti munkaeröhiány esetén első lépésként a legtöbb vállalkozásnál túlórát írnak elő, illetve erőteljes hangsúlyt fektetnek a munkaidő jobb kihasználására és a termelékenység növelésére.

Néhány fővel megtoldható a dolgozói létszám a fizetés nélküli szabadságon lévő kismamák visszahívásával, vagy a részmunkaidősök munkaidejének növelésével, de ha erre nincs mód, új munkavállalók számára kell felvételt hirdetni. Szűkülő munkaerőpiaci helyzetben megoldást jelenthet a diákmunka, az alvállalkozói szerződések, a munkaerökölcsönzés, vagy az egyszerüsített foglalkoztatás (alkalmi munka, idénymunka). Idénymunka esetén azonban az előzőekben említett elszívó hatással éppen az érintett ágazatokban (mezőgazdaság, vendéglátás, építöipar) kell fokozottan számolni. A munkaerő szükséglet biztosítása érdekében a távolabbi lakhellyel rendelkezők munkába járásához a vállalkozások egy része saját buszjáratokat indít, vagy akár az ország más régióiból költözők számára munkásszállást üzemeltet vagy lakást bérel.

A vállalkozás további atipikus foglalkoztatási lehetőségekből is választhat a munkaerököltségei befolyásolása érdekében. Ezek között egyre népszerübb megoldás a munkaerő-kölcsönzés, melynek sajátosságát az adja, hogy egy háromszereplős jogviszony jön létre (kölcsönbeadó, a kölcsönvevő és a kölcsönzött munkavállaló). A munkáltató a kölcsönbeadó, aki „,a vele kölcsönzés céljából munkaviszonyban álló munkavállalót ellenérték fejében munkavégzésre a kölcsönvevőnek ideiglenesen átengedi."6 Az „ellenértékként” fizetett munkaerő-kölcsönzési díj nem minősül bérköltségnek és a toborzási, illetve kiválasztási folyamatot is a munkaerökölcsönző partner bonyolítja.

Amennyiben a felsorolt intézkedésekkel nem sikerül az egyensúlyt megteremteni, elkerülhetetlen a szervezeti célok felülvizsgálata és az „újratervezés” az addig alkalmazott technológia megváltoztatását is eredményezheti (pl. automatizálás).

\subsection{Munkaidőkihasználás és az élőmunka teljesítményének elemzése}

A rendelkezésre álló munkaidő keret meghatározásához minden évben rögzítik a munkarend szerinti napok számát (a naptári napok száma csökkentve a pihenőnapok és fizetett ünnepnapok számával) és munkavállalói csoportonként a munkaidő-beosztás figyelembevételével meghatározzák az állományi létszám által teljesíthető (elemzésnél teljesített) napok számát.

\footnotetext{
${ }^{6}$ Az Európai Parlament és a Tanács 2008/104/EK irányelve alapján
} 


$$
\text { Munkaerő-felhasználási mutató (B), \% }=\frac{\text { Teljesített napok száma }}{\text { Munkarend szerinti napok száma }} * 100
$$

A mutató segítségével számítható az egész napos távollétek aránya:

Egésznapos távollétek aránya, \% = 100\% - Munkaerő-felhasználási mutató (B)

Az egésznapos távollét a munkarendszerinti napokról való igazolt és igazolatlan hiányzást is magába foglalja. Az egésznapos távollét mellett számszerüsíthető a törtnapi távollétek nagysága és aránya is:

Munkanap átlagos hossza, óra/nap $=\frac{\text { Teljesített órák száma túlórák nélkül }}{\text { Teljesített napok száma }}$

A munkanap átlagos hosszának ismeretében számítható a munkaidő-kihasználás mértéke is:

Munkaidő-kihasználási mutató (A), \% $=\frac{\text { Munkanap átlagos hossza }}{\text { Munkanap törvényes hossza }}$

vagy:

Munkaidő-kihasználási mutató (B), \% $=\frac{\text { Teljesített órák száma }}{\text { Teljesíthetó órák száma }}$,

ahol

Teljesíthető órák száma = Teljesített napok száma x Munkanap törvényes hossza és

Törtnapi távollétek aránya, \%=100\% - Munkaidő-kihasználási mutató.

Az egész napos és a törtnapi távollétek együttes arányát jellemzi a munkaidőalap-kihasználási mutató, melynek segítségével számítható az összes távollét aránya is:

Munkaidőalap-kihasználási mutató, \% = $\frac{\text { Teljesített órák száma }}{\text { Munkaidőalap }}$,

ahol

Munkaidőalap $=$ a munkarend szerinti napok száma x a munkanap törvényes hossza ( 8 óra/nap)

és

Összes távollét aránya, \% = 100\% - Munkaidőalap-kihasználási mutató 
A fentiek alapján pedig:

Munkaidőalap-kihasználás = Munkaerő-felhasználás x Munkaidő-kihasználás

A munkahelyén jelen lévő munkavállaló azonban a teljes munkaidő alatt nem dolgozik, rövidebb-hosszabb kieső idővel számolni kell. Az így keletkező „,veszteségidő” oka lehet áramszünet, a munkafolyamatban részt vevő gépek, berendezések meghibásodása, kötelező pihenőidő (a munka jellege miatt), munkaszervezési probléma, vagy a munkavállaló fegyelmezetlensége is. A veszteségidő speciális csoportjába tartozik a selejt javítására, pótlására fordított idő, ami szintén többletköltséggel jár.

A vállalkozások a fizikai munkakörökre teljesítménykövetelményt határoznak meg (munkanorma), ami lehet időnorma vagy teljesítménynorma. Az időnorma azt az időmennyiséget jelöli, amely az adott munka(folyamat) elvégzéséhez a meghatározott müszaki és munkaszervezési feltételek mellett az elöírt minőségben szükséges, a teljesítménynorma pedig arra a menynyiségre vonatkozik (pl. db), amit adott időegység alatt le kell(ene) gyártani.

A ténylegesen felhasznált és a munkanorma szerinti idő hányadosa az átlagos teljesítményszázalék, ami optimálisan (vagyis megfelelő normakialakítás és munkavégzés) esetén 100\%.

A napi 8 órás törvényes munkaidő mellett vannak rövid munkaidőben foglalkoztatott (részmunkaidős) munkavállalók is, akik aránya potenciált jelenthet a vállalkozás számára növekvő élőmunkaigény esetén. Amennyiben az aktuális szerződések alapján a törvényes munkaidőben (átmenetileg) nem tudja a vállalkozás a kitüzött célokat teljesíteni, túlórát rendelhet el egy adott munkakörre vagy müszakra vonatkozóan. Törekedni kell azonban arra, hogy a túlórák aránya minél kisebb legyen, ugyanis a túlóra-pótlék (valamint a kapcsoló közterhek) jelentős többletköltséget eredményezhetnek, ráadásul a 8 órás munkaidőt követően a teljesítmény is jellemzöen alacsonyabb.

\subsection{Bérgazdálkodás}

A vállalkozás személyi jellegü ráfordításainak tervezésekor - a létszám meghatározása mellett - a másik pillért a bérgazdálkodás jelenti. Az alkalmazottak munkájának ellenértéke a bér, amit a munkáltató a béren kívüli juttatásokkal egészíthet ki.

Bérnek minősülnek többek között az alábbiak:

- alapbér, a munkakör ellátásához kapcsolódóan

- pótlékok, amelyek a munkakör speciális jellege miatt illetik meg az alkalmazottat (pl. éjszakai müszak)

- prémium (elöre meghatározott célkitüzés elérése esetén)

- jutalom (a kiemelkedő teljesítmény utólagos elismerése)

Az alapbér meghatározásokat jellemzően az időbért rögzítik (havibér, napibér, órabér), de elöfordulhat a bérforma megadásánál a teljesítménybérezés. Az időbér alkalmazásával tervezhe- 
tők a költségek, de önmagában általában teljesítménykövetelményt nem tartalmaz, csak a ,jelenlétre" kötelezi a dolgozót. A teljesítménybér esetén adott idő alatt előállítandó mennyiséget (pl. db) rögzítenek, ami kiegészíthető minőségi paraméterekkel el (pl. legalább mekkora arányban I. osztályú).

A munkaszerződés megkötésénél, valamint az éves bérkorrekciók alkalmával tekintettel kell lenni a törvényi elöírásokra, valamit az aktuális munkaeröpiaci környezetre is. Előbbiek közül hazánkban a minimálbér és a szakmai bérminimum összegét kormányrendelet szabályozza, amely 2020. január elsejétől 161.000, illetve 210.600 forint ${ }^{7}$. Utóbbi a legalább középfokú iskolai végzettséget, vagy szakképzettséget igénylö munkakörök betöltése esetén rögzítendő legalacsonyabb alapbért jelenti heti 40 órás foglalkoztatás esetén. Az intézkedés a munkavállalók oldaláról egyfajta biztosítékként is felfogható, más kérdés, hogy a munkáltatók egyrésze - tekintettel a munkaerőpiaci keresletre - kénytelen ennél magasabb bért alkalmazni.

A piaci versenyben azonban alulmaradnak azok a cégek, amelyek kifejezetten élőmunkaigényes tevékenységet folytatnak és/vagy nem megfelelö hatékonysággal müködnek.

A munkavállalóknak fizetett bruttó béren felül 15,5\% szociális hozzájárulási adó ${ }^{8}$, valamint a 1,5\% szakképzési hozzájárulás ${ }^{9}$ is terheli a vállalkozásokat az élőmunkához kapcsolódóan. Ezeken felül további költséget jelenthet a rehabilitációs hozzájárulás, ha az elöírt foglalkoztatási feltételeknek nem felel meg a vállalkozás. Amennyiben ugyanis egy cég foglalkoztatottjainak átlagos statisztikai állományi létszáma meghaladja a 25 föt, de a megváltozott munkaképességü munkavállalók száma nem éri el az összlétszám 5 százalékát, a vállalkozás köteles rehabilitációs hozzájárulást fizetni, amelynek összege a minimálbér kilencszerese/fö/év (vagyis 2020-ban 1.449.000 fö/év) ${ }^{10}$. A fizetendő szociális hozzájárulási adó és szakképzési hozzájárulás összege azonban alacsonyabb lehet, ha a vállalkozás a foglalkoztatotti körének alakításakor figyelembe veszi azokat a lehetőségeket, amelyeket a tv. 10-16. §-a tartalmaz (pl. szakképzettséget nem igénylő munkakörben foglalkoztatottak, munkaerőpiacra lépők után érvényesíthető kedvezmények).

A béren kívüli juttatásokra a vállalkozás által elfogadott cafeteria rendszer biztosítja a keretet, ugyanakkor ki kell emelni, hogy ez ehhez kapcsolódó adó és járulékkötelezettségek miatt a cégek jellemzően a személyi jövedelemadó törvény által adómentes juttatások közé sorolt elemeket preferálják, hiszen így a kapcsolódó adóék csökkenthető (bérként 43,16\%). 2019-től az adóváltozások következtében a bérkifizetésnél kedvezőbb adózási szabályok vonatkoznak például az óvodai és bölcsődei támogatásra, vagy a SZÉP-kártyára utalt összegre. Utóbbi esetében a magánszemély számára adómentesen adható összeg (évente 450 ezer forint ${ }^{11}$ ) összevont adó-

\footnotetext{
${ }^{7}$ 367/2019. (XII. 30.) Kormányrendelet. A béremelés mértékéről 2021.01.20-ig nem született megállapodás.

${ }^{8}$ 2018. évi LII. törvény a szociális hozzájárulási adóról

9 2011. évi CLV. törvény a szakképzési hozzájárulásról és a képzés fejlesztésének támogatásáról

${ }^{10}$ 2011. évi CXCI. törvény a megváltozott munkaképességủ személyek ellátásairól és egyes törvények módosításáról

${ }^{11}$ 1995. évi CXVII. törvény a személyi jövedelemadóról
} 
terhe 2020. július elsejétől 30,5\%, de koronavírus járvány gazdasági hatásait enyhítendő átmenetileg csak $15 \%{ }^{12}$. A munkaerő költségek közé tartozik az utazási költségtérítés, a lakhatási támogatás és a továbbképzésre fordított összeg is.

\subsection{A bérgazdálkodás elemzéséhez használt főbb mutatók}

A bérköltség elemzésekor a terv és tény adatok eltérését, illetve az előző időszakokhoz képest történt változást szükséges megvizsgálni, a hangsúlyt az eltérések okának felkutatására helyezve. Kérdésként merül fel az is, hogy indokolt volt-e az adott szintü bérkiáramlás és van-e lehetőség ennek csökkentésére és ha igen, a bérköltség mely elemeinek visszaszorításával, vagy növelésével (lásd pl. SZÉP kártya).

Az átlagbér meghatározható havi vagy éves adatok alapján is:

$$
\text { Átlagbér }=\frac{\text { Bérköltség }}{\text { Létszám }}
$$

A vállalkozási szintủ bértömeg adatokat érdemes a fizikai dolgozók csoportjára, vagy az egyes üzemekre, költségviselőkre, illetve munkakörökre vonatkozóan is értékelni és számszerüsíteni a létszámváltozásból, valamint a bérnövekményből (átlagbér) eredő hatást.

A vállalati költségek szerkezetének alakulása fontos információ a vállalkozás vezetői számára. Ennek részeként az élőmunkához kapcsolódó ráfordítások nagyságrendjét is viszonyíthatjuk a vállalati költségekhez, amelynek leggyakrabban használt mutatói az alábbiak:

$$
\text { Bérigényesség, } \%=\frac{\text { Bérköltség }}{\text { Összes költség }} \text { vagy } \frac{\text { Személyi jellegü ráfordítások }}{\text { Összes költség }}
$$

Az elemzések során különösen fontos a bérköltség vizsgálata abból a szempontból, hogy adott bérszínvonal mellett mekkora árbevétel és eredmény elérésére képes a vállalkozás. Ennek mérésére alkalmas mutató a bérhányad (vagy bérszint, \%), valamint a bérhatékonyság (a bérhányad reciproka).

$$
\begin{gathered}
\text { Bérhányad, } \%=\frac{\text { Bérköltség }}{\text { Nettó árbevétel }} \\
\text { Bérhatékonyság }=\frac{\text { Nettó árbevétel }}{\text { Bérköltség }}
\end{gathered}
$$

Az egységnyi (1 Ft) bérköltségre jutó eredményt a bérarányos jövedelmezőség mutatóval számszerüsíthetjük:

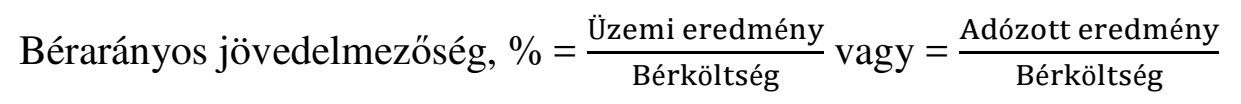

${ }^{12}$ 140/2020. (IV. 21.) Kormányrendelet (frissítve: 2020.04.23.) 
A mutató nevezőjében az összes személyi jellegü ráfordítás is szerepelhet a vállalkozás döntése alapján. A fentiek mellett sajátos jövedelmezőségi mutató az élőmunka-arányos jövedelmezőség, amely az egy före jutó eredményt mutatja:

$$
\text { Élőmunka-arányos jövedelmezőség, Ft/fő }=\frac{\text { Üzemi eredmény }}{\text { Létszám }} \text { vagy }=\frac{\text { Adózott eredmény }}{\text { Létszám }}
$$

A kereskedelmi munka sajátos jellegére tekintettel a fentiek mellett vagy helyett az alábbi mutatók is informatívak lehetnek az elemzés során:

$$
\begin{gathered}
\text { Bérhányad, } \%=\frac{\text { Eladáshoz kapcsolódó bérköltség }}{\text { Forgalom }} \\
\text { Teljesítmény, Ft/fö }=\frac{\text { Forgalom }}{\text { Átlagos dolgozói létszám }} \\
\text { Leterheltség }=\frac{\text { Vevők száma }}{\text { Eladók száma }} \\
\text { Minőségi mutató }=\frac{\text { Forgalom }}{\text { Vevők száma }}
\end{gathered}
$$

A három utóbbi mutató között felírható az alábbi összefüggés:

$$
\text { Teljesítmény = Leterheltség x Minőségi mutató }
$$

\section{Források}

1) Ambrus Rita Anna (2020): Személyi jellegü ráfordítások optimalizálásának aktuális kérdései. Óbudai Egyetem, Budapest: https://kgk.uni-obuda.hu/publikaciok/vallalkozasfejlesztes-10

2) Birher Ilona - Pucsek József (2009): A vállalkozások tevékenységének gazdasági elemzése. Budapest: Perfekt Gazdasági Tanácsadó, Oktató és Kiadó Zrt.

3) Bíró Tibor, Kresalek Péter, Pucsek József, Sztanó Imre (2016): A vállalkozások tevékenységének komplex elemzése. Budapest: Perfekt Gazdasági Tanácsadó, Oktató és Kiadó Zrt.

4) Kresalek Péter - Blumné Bán Erika (2011): A vállalati tevékenységek elemzésének módszertana I. - Teljesítmény és erőforrás elemzés. Budapest: Perfekt Gazdasági Tanácsadó, Oktató és Kiadó Zrt.

5) 2011. évi CLV. törvény a szakképzési hozzájárulásról és a képzés fejlesztésének támogatásáról

6) 2011. évi CXCI. törvény a megváltozott munkaképességü személyek ellátásairól és egyes törvények módosításáról

7) 2018. évi LII. törvény a szociális hozzájárulási adóról

8) 1995. évi CXVII. törvény a személyi jövedelemadóról 
9) 367/2019. (XII. 30.) Kormányrendelet a kötelező legkisebb munkabér (minimálbér) és a garantált bérminimum megállapításáról

10) 140/2020. (IV. 21.) Kormányrendelet (frissítve: 2020.04.23.) a Gazdaságvédelmi Akcióterv keretében a koronavírus-járvány gazdasági hatásainak mérséklése érdekében szükséges adózási könnyítésekröl 


\section{Kereskedelem és vendéglátás jellegzetességei}

Az eddigi fejezetek során áttekintettük mindazon elemzési témaköröket, amelyek általánosságban szükségesek és használatosak a vállalkozások tevékenységének elemzéséhez, függetlenül attól, hogy milyen ágazatban tevékenykednek. A készletgazdálkodás (8. fejezet) és tárgyi eszköz-gazdálkodás (9. fejezet) témaköröknél külön jeleztük, hogy melyek azok a módszerek, amelyek kifejezetten a termelő vállalkozások esetében nyújtanak segítséget. E fejezet célja pedig kitekintést adni arról, hogy a fent jelezett témakörökben, továbbá egyéb más területeken milyen sajátosságok lelhetőek fel a kereskedelem és bizonyos esetekben a vendéglátás területén. Ugyanakkor a fejezet során több esetben utalást fogunk tenni a korábbi fejezetekben leírt ismeretekre is, amelyek relevánsak a vizsgált két terület esetében is.

\subsection{Az áruforgalom és készletgazdálkodás sajátosságai a kereskedelemben}

A termelö vállalkozások esetében nem, ellenben a kereskedő vállalkozások esetében tipikusan használt és megjelenő készlettípus az árukészlet, amely olyan készleteket foglal magában, amelyeket a vállalkozás kizárólag továbbértékesítési céllal szerez be, azokon semmilyen átalakítási folyamatot nem végez, hanem változatlan formában értékesíti őket tovább. Ide tartoznak a kereskedelmi árukészletek, a közvetített szolgáltatások és a göngyölegek (csomagolási eszközök, edények, ládák, kartonok, rekeszek, amelyek az árut annak szállítása során védik - fontos jellemzőjük, hogy többször felhasználhatók és az eladónak visszavásárlási kötelezettsége van rájuk). Figyelmünket a továbbiakban a kereskedelmi árukészletekre irányítjuk, melyek tovább osztályozhatók nagykereskedelmi, kiskereskedelmi, ill. vendéglátó-ipari árukra.

A kereskedelmi vállalkozások alapvetô céljuk szerint olyan profittermelésre létrejött vállalkozások, amelyek más termelők által létrehozott késztermékeknek a fogyasztók irányába történő eljuttatásában müködnek közre. Ennek megfelelően fontos összekötő szerepet játszanak a termelés és fogyasztás térbeli, időbeli és választékbeli eltolódásának összehangolásában. Az ilyen vállalkozásoknál felhalmozódó árukészletek szintjét befolyásolja

- a fogyasztók részéről támasztott kereslet és forgalom nagysága, ill. összetétele;

- a vállalkozás által forgalmazott termékek választéka;

- a beszerzési forrásokhoz való hozzáférés lehetősége, megbízhatósága és gyakorisága;

- a beszerzési tevékenység minősége;

- és általában véve a gazdaság állapota, ciklikussága.

A kereskedelmi vállalkozások által lebonyolított áruforgalom tulajdonképpen a termelő tevékenység és a fogyasztás közé ékelt folyamat, amelyet három részfolyamatra bonthatunk. Időrendiségét tekintve a beszerzéssel indul, a készletezéssel folytatódik, majd az értékesítéssel zárul. Logikailag azonban valójában a folyamat első elemeként az értékesítésre tekinthetünk, hiszen a vevőktől érkező kereslet határozza meg, hogy milyen mennyiségü és minőségű árut szerez be a kereskedelmi vállalkozás, amelyet aztán majd készletre vesz (11.1. ábra). 


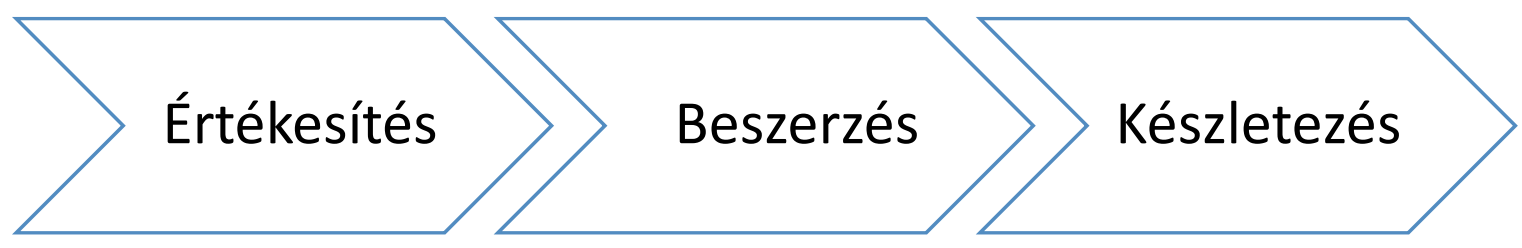

11.1. ábra Az áruforgalmi folyamat szakaszai logikai sorrendben

Forrás: Bán és mtsai. (2017)

A három részfolyamatot azért szükséges önmagukban és egymáshoz viszonyítottan is vizsgálni, mert bármelyikben bekövetkező zavar, a teljes áruforgalomra és a vevők kiszolgálására nézve is negatív hatással lehet. Az értékesítési részleg feladata, hogy minél pontosabb előrejelzést adjon a várható keresletről. A rossz prognózis készlethiányhoz, ezáltal vevői bizalomvesztéshez vezethet.

A beszerzés az a folyamat, amely az ún. árualap létrehozásáért felel, azaz olyan árukészlet felhalmozásáért, amelyre kereslet mutatkozik, és amelynek értékesítése nem ütközik akadályokba. Másrészt biztosítania kell, hogy az áruellátás folyamatos legyen, amihez megbízhatóan teljesítő, az elvárt minőségben rendszeresen szállítani képes beszállítókra van szükség. A beszerzés által biztosított árukészletet raktározni, tárolni szükséges addig, amíg a vevők számára értékesítésre kerül. Ezt egyrészt rendszerezetten és átláthatóan, másrészt az áruk sértetlenségét, felhasználhatóságát és értékesíthetőségét lehetővé tévő körülmények között kell megtenni. Továbbá minderről olyan nyilvántartást kell vezetni, amely a készletállomány állapotának folyamatos nyomon-követését teszi lehetővé, annak hiánya vagy jövőbeni hiánya esetén pedig az új beszerzés szükségességét idejében jelezni képes. Végül az értékesítés feladata, hogy a felhalmozott árukészleteket minél rövidebb ideig kelljen tárolni és minél hamarabb továbbértékesítésre kerüljenek, a kereslet és a kínálat egymásra találjanak.

\subsubsection{Az áruforgalom átfogó elemzése}

Az áruforgalom átfogó elemzése során az a cél, hogy a három részfolyamat összhangját, egymáshoz való viszonyát térképezzük fel. Ezt követheti a részfolyamatok önmagukban történő elemzése.

Az átfogó vizsgálat eszköze az áruforgalmi mérlegsor, amely tulajdonképpen egy olyan egyenlőség, ami az áruforgalmi egyensúlyt szimbolizálja. Az egyenletet kifejezhetjük mennyiségi (valamilyen mértékegységbeli) adatokkal vagy pénzértékben. Előbbi esetben arra kell figyelni, hogy az árukészlet elemei egyenérték-számítás segítségével egységesen értékelhetők legyenek függetlenül a minőségi és összetételbeli eltéréseiktől. Utóbbi esetben az árak torzító hatását kell kiküszöbölni - azaz minden tételt vagy beszerzési, vagy fogyasztói áron kell figyelembe venni és valamilyen bázisidőszakon értékelni.

$$
\text { Nyitókészlet }\left(\mathrm{K}_{\mathrm{Ny}}\right)+\text { Beszerzés }(\mathrm{B})=\text { Értékesítés }(E ́) \text { + Zárókészlet }\left(\mathrm{K}_{\mathrm{Z}}\right)
$$

Az egyenlet bal oldala jelenti az ún. árualapot, amely a jövőbeni értékesítés alapfeltételéül szolgál. Mivel az áruforgalmi egyenletet adott időszakra készítjük el, ezért a vizsgált időszak 
első napján már rendelkezésre álló készletállományt nyitókészletként tartjuk nyilván. Ehhez jön a vizsgált időszakban beszerzésre került áruk állománya. Az egyenlet jobb oldalán található meg az értékesített árukészlet, valamint az adott időszakban értékesítésre végül nem kerülö áruk állománya (zárókészlet formájában). Utóbbi egyfajta maradvány, jelenléte mindenképpen indokolt és nem negatív jelenség, mivel egyúttal a következő értékesítési időszak nyitó állományaként is szolgál, így biztosítva az értékesítés folyamatosságát a két időszakon átívelően.

Az áruforgalmi mérlegsor kibővített formája lehetőséget nyújt arra, hogy az egyenlet mindkét oldala egyéb tételekkel is bővülhessen vagy szükülhessen:

$$
\begin{aligned}
& \text { Nyitókészlet }\left(\mathrm{K}_{\mathrm{Ny}}\right)+\text { Beszerzés }(\mathrm{B})+\text { Egyéb készletnövekedés } \\
& =\text { Értékesítés }(\mathrm{E})+\text { Egyéb készletcsökkenés + Zárókészlet }\left(\mathrm{K}_{\mathrm{Z}}\right)
\end{aligned}
$$

A készletnövekedés adódhat leltári többletböl, értékvesztési visszaírásból, térítés nélküli átvételből vagy apportból, míg a készletcsökkenés leltárhiányból, értékvesztési leírásból, térítés nélküli átadásból vagy apportból, esetleg selejtből, visszáruból, leértékelésből.

Az áruforgalmi mérlegsor egyes részeinek segítségével több mutatószámot is képezhetünk, amelyek ugyan csak nagy vonalakban, de képesek megmutatni a közöttük lévő fontosabb öszszefüggéseket (11.1. táblázat).

\section{1. táblázat Az áruforgalmi mérlegsor elemeiböl képezhető mutatók}

\begin{tabular}{|l|c|}
\hline \multicolumn{1}{|c|}{ Mutató megnevezése } & Mutató \\
\hline Árufedezettség & $\frac{\mathrm{K}_{\mathrm{Ny}}+\mathrm{B}}{\mathrm{E}} \times 100$ \\
\hline Értékesítés-beszerzés viszonya & $\frac{\mathrm{E}}{\mathrm{B}} \times 100$ vagy $\frac{\mathrm{B}}{\mathrm{E}} \times 100$ \\
\hline Átlagkészlet & $\frac{\mathrm{K}_{\mathrm{Ny}}+\mathrm{K}_{\mathrm{Z}}}{2}$ \\
\hline Átlagos forgási sebesség (fordulatban) & $\frac{\dot{\mathrm{E}}}{\overline{\mathrm{K}}}$ \\
\hline Készletváltozás & $\frac{\mathrm{K}_{\mathrm{Z}}}{\mathrm{K}_{\mathrm{Ny}}} \times 100$ \\
\hline
\end{tabular}

Forrás: Bán és mtsai. (2017)

Az árufedezettség mutatója arról ad képet, hogy az értékesített mennyiséget milyen mértékben haladta meg az árualap. Értéke minden esetben legalább 100\%. Az értékesítés és beszerzés viszonya két reciprok mutatóval is értékelhető. Az É/B formában azt mutatja meg, hogy a beszerzett áruk mekkora része került értékesítésre, míg a B/É formában azt mutatja meg, hogy az értékesítés mekkora részét fedezte a vállalkozás beszerzésből - ha 100\%-nál nagyobb ez a 
mutató akkor a készletek növekedtek az időszak végére, ha kisebb, akkor csökkentek és az értékesítés egy része a nyitókészlet-állományból történt.

Az átlagkészlet a vizsgált időszak átlagos készletállományát számszerüsíti. (Részletesebb számítását lásd a 2.4-es fejezetben.) A fordulatokban mért átlagos forgási sebesség azt mutatja meg, hogy az árukészletek hányszor térülnek meg a forgalomból. Annál kedvezőbb az értéke, minél magasabb. A készletváltozás értéke a vizsgált időszak záró és nyitó készletállományát veti össze. Ha értéke 100\%-nál nagyobb, akkor nőtt a készletállomány, a beszerzések meghaladták az értékesítéseket. Ha értéke 100\%-nál kisebb, akkor csökkent a készletállomány, a beszerzések nem nyújtottak teljes mértékben fedezetet az értékesítésre. Ezen mutatók nem elsösorban önmagukban, hanem sokkal inkább az ágazati benchmarkokhoz vagy a vállalkozás saját korábbi, vagy terv értékeihez hasonlítva szolgáltatnak információkat.

\subsubsection{A beszerzés (áruellátás) elemzése}

Az árukészletek felhalmozásának első lépése az árubeszerzés, amelynek során meghatározásra kerül a beszerzendő áruk összetétele és mennyisége (a várható forgalomtól, aktuális árukészletállománytól, raktározási és pénzügyi lehetőségektől, üzletpolitikai céloktól függően), a szállítók kiválasztása, a szállítási szerződések megkötése és az árurendelés, ill. az áruátvétel. Erre azért kell különösen nagy hangsúlyt fektetnie a kereskedelmi vállalkozásoknak, mert értékesítési árbevételük 70-80\%-át az árukészletek beszerzési költségei adják (Bán és mtsai, 2017).

A beszerzési igények meghatározását a fogyasztói oldalról várható kereslet elemzése előzi meg, amely a piac nyomon-követését, a vevői igények ismeretét megkövetelő előrejelzési feladat, mely nem a gazdasági elemzés témakörébe tartozik.

A beszerzési szükségletek ismeretében kell meghatározni a lehetséges beszállítók körét. Ennek során a potenciális beszállítók rangsorolásra kerülnek aszerint, hogy milyen áron és minőségben, milyen megbízhatósággal, milyen sürüséggel és milyen szállítási, ill. fizetési feltételekkel tudják a beszerzendő mennyiséget biztosítani. A szállítók minősítése történhet komplex, súlyozásos pontozási módszerrel, amelyben a szállítók iránt támasztott követelmények súlyozottan kerülnek összehasonlításra. Szintén gyakran használatos eszköz az ún. ABC analízis, amely valamilyen korábban említett szempont(ok) szerint „A”, „B” és „C” kategóriákba rendezi a beszállítókat, így meghatározva azok fontosságát.

Az árubeszerzések gyakoriságának megállapításához a vállalkozásnak ismernie kell az optimális rendelési tételnagyságot, amely azt az árukészlet-mennyiséget jelenti, amely mellett azok összköltsége a lehető legalacsonyabb (készlettartási költségek, készlet-utánpótlási költségek, készlethiány-költségek). 
Az optimális rendelési tételnagyság az alábbi képlettel határozható meg (Bán és mtsai, 2017):

$$
q=\sqrt{\frac{2 \times B \times K}{p \times k}}
$$

ahol:

- $\quad \mathrm{q}=$ az optimális rendelési tételnagyság;

- $\quad \mathrm{B}=$ az adott időszak beszerzési szükséglete;

- $\mathrm{K}=$ a rendelés egységköltsége (egy rendelés feladásának a költsége);

- $\mathrm{p}=\mathrm{az}$ áru beszerzési ára;

- $\mathrm{k}=\mathrm{az}$ árukészletek készlettartási költségeinek átlagos mértéke.

Az optimális rendelési tételnagyság ismeretében meghatározható az adott időszakban szükséges, feladandó rendelések száma, továbbá annak az időnek a hossza (áru-utánpótlási idő), amely két rendelésfeladás között telik el.

$$
\begin{gathered}
\text { Rendelések száma az adott időszakban }=\frac{\mathrm{B}}{\mathrm{q}} \\
\text { Áru - utánpótlási idő }=\frac{\text { Adott időszak hossza (napokban) }}{\text { Rendelések száma az adott időszakban }}
\end{gathered}
$$

A megfelelő szállítók kiválasztását követően a beszerzendő árukészletek ismeretében történhet meg a szállítókkal való szerződések megkötése. Ebben a fázisban az elemzők feladata az, hogy megvizsgálják, az értékesítendő áruk beszerzése milyen mértékben biztosított, az áruellátás folyamatos és fennakadások nélküli lesz-e. A beszerzés szerződéses fedezettségének mutatója a beszerzésre előirányzott árumennyiség azon hányadát adja meg, amelyre a vállalkozásnak már van beszállítói szerződése. Az a kívánatos, ha értéke a vizsgált időszak kezdetén 100\% körüli, ill. az érintett időszakot megelőzően kb. 80\%-os.

ahol:

$$
\text { Szerződéses fedezettség }=\frac{\mathrm{B}_{\mathrm{S}}}{\mathrm{B}_{\mathrm{E}}}
$$

- $\mathrm{B}_{\mathrm{S}}=\mathrm{az}$ adott időszakra szerződéssel már fedezett áruk értéke;

- $\mathrm{B}_{\mathrm{E}}=\mathrm{az}$ adott időszakban beszerezni kívánt áruk értéke.

Végül az árubeszerzés folyamatának utolsó mozzanata az áruk beérkeztetése és átvétele, mely optimális esetben olyan ütemezéssel történik, ahogyan azt a szerződések szerint várni lehet. Azonban, mivel a fogyasztók kiszolgálását komolyan befolyásolhatja, ha a hibás, vagy csúszó szállításból eredően készlethiány lép fel, ezért szükséges a beszerzések ütemességének vizsgálata. Ennek mutatója szintén a beszerzésre előirányzott árumennyiséghez viszonyítva adja meg, hogy mekkora értékü áru beszerzése történt meg időben az adott időszakban. Elvárható értéke $100 \%$. 


$$
\text { Beszerzések ütemességi mutatója }=\frac{\mathrm{B}_{\mathrm{T}}}{\mathrm{B}_{\mathrm{E}}}
$$

ahol:

- $\mathrm{B}_{\mathrm{T}}=\mathrm{az}$ adott időszakra ténylegesen, időben beérkezett áruk értéke.

\subsubsection{A készletezési tevékenység (árukészlet-állomány) elemzése}

A készletállományok vizsgálata a kereskedelemben is történhet egy időpontra nézve (pl. leltározás során adott időszak nyitó vagy zárókészletének megállapításával), vagy egy időszakra nézve. Utóbbi esetben időszaki készletekröl beszélünk, amely az időszak során átlagosan a vállalkozás rendelkezésére áll. A 2.4-es fejezetben bemutatott kronologikus átlag segítségével számolható havi, negyedéves, féléves vagy éves átlagkészlet is. Ezek használatával vizsgálható az árukészletek állományának időbeli változása több időszakon vagy több időponton keresztuil.

Az árukészletek hatékonyságát vizsgálva ugyanúgy használhatóak a 8.2.2-es fejezetben bemutatott forgási, hatékonysági és rugalmassági mutatók, mint más egyéb készlettípusok esetében. A forgási sebesség (fordulatokban mérve), az árukészlet rugalmassága és az áruk átlagos tárolási idejének kiszámítási logikája megegyezik a más készletfajták hasonló mutatóinak számítási módjával, azonban a számlálóban és a nevezőben is vannak eltérések (11.2. táblázat). A mutatók értelmezése azonban teljesen megegyezik a korábban leírtakkal.

\section{2. táblázat Az árukészletek hatékonysági mutatói}

\begin{tabular}{|l|c|}
\hline \multicolumn{1}{|c|}{ Mutató megnevezése } & \multicolumn{1}{c|}{ Mutató } \\
\hline $\begin{array}{l}\text { Árukészletek forgási sebes- } \\
\text { sége }\end{array}$ & $\frac{\text { Forgalom }}{\text { Árukészletek átlagos értéke }}$ \\
\hline $\begin{array}{l}\text { Árukészlet-rugalmassági } \\
\text { mutató }\end{array}$ & $\frac{\text { Árukészletek százalékos változása }}{\text { Forgalom százalékos változása }}$ \\
\hline Áruk átlagos tárolási ideje & $\frac{\text { Árukészletek átlagos értéke }}{\text { Egy napi eladott áruk beszerzési értéke }}$ \\
\hline
\end{tabular}

\subsubsection{Az értékesítés elemzése}

A forgalom szerkezetének vizsgálata tulajdonképpen az értékesítésből befolyó értékesítési bruttó árbevétel részekre bontását jelenti. A forgalom fogyasztói áron mérve nem más, mint az eladott áruk mennyisége szorozva azok egységárával, ez az, amelyet a fogyasztók a kereskedelmi vállalkozásnak kifizetnek. Két részre bontható, egyrészt az általános forgalmi adóra (ÁFA), melyet a vállalkozásnak be kell fizetnie az államkasszába, valamint az értékesítés nettó árbevételére, amelyet magánál tart. A nettó árbevétel jelentős részét (jellemzően 70-80\%-ot) teszi ki az értékesített áruk beszerzési értéke, amely költségként jelentkezett korábban a vállalkozás számára, és értékesítéskor térül meg. A fennmaradó részt nevezzük árréstömegnek, amely fedezetet nyújt a vállalkozás egyéb más költségeire (pl. működés, logisztika stb.) valamint az egyéb költségek levonása után az eredményt képezi, amely a vállalkozás végső célja 
(11.2. ábra). Fel kell hívni a figyelmet arra, hogy az árréstömeg és a haszonkulcs fogalma nem keverendő össze, ezek tisztázására a fejezet későbbi részében kerül sor.

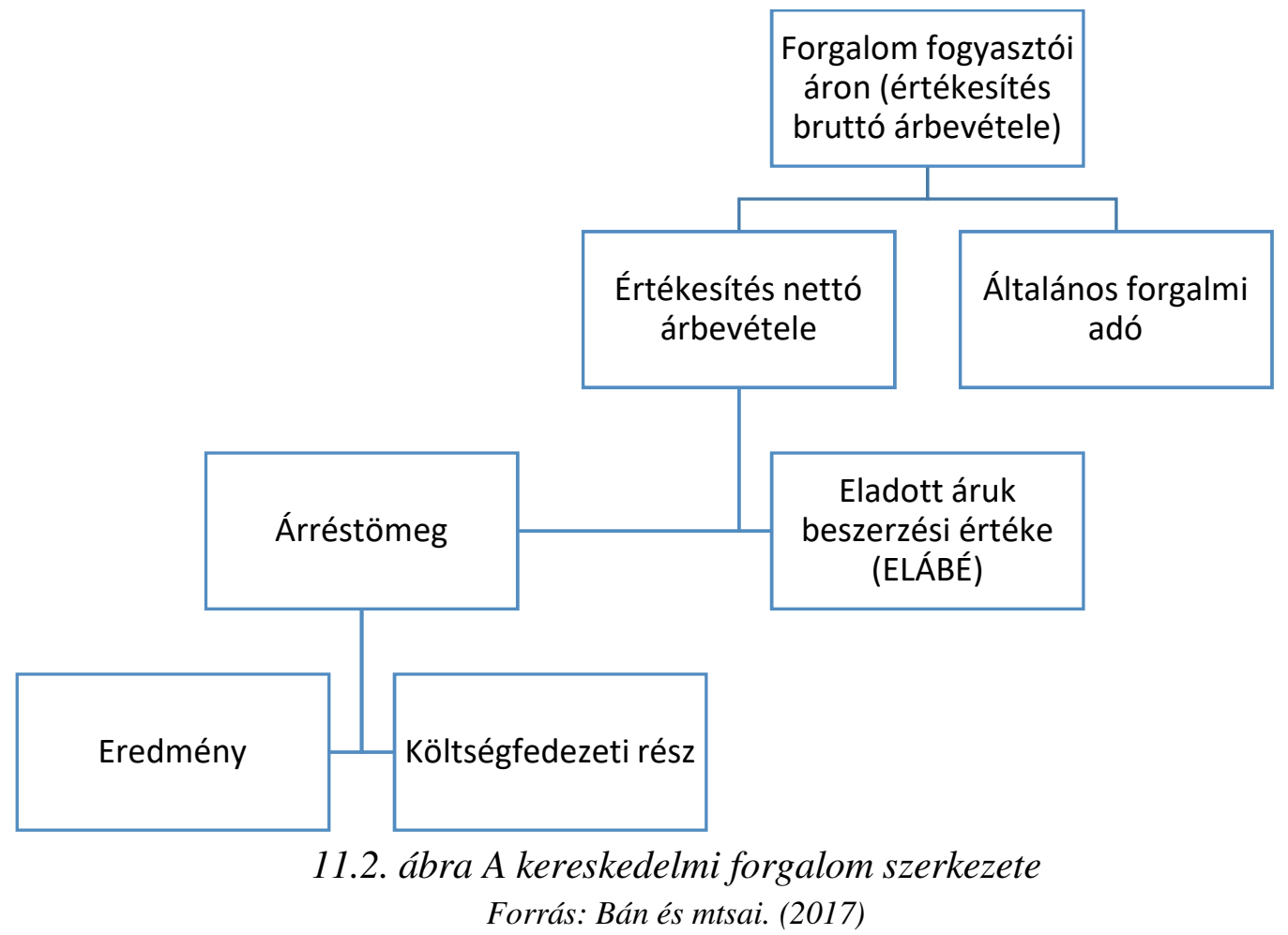

Általánosságban elmondható, hogy a kereskedelmi vállalkozások költségeik csökkentésén kívül forgalmuk növelésével tudnak eredményt növelni, ráadásul minél nagyobb mértékben nő a forgalmuk, annál nagyobb mértékben nő az eredményük. Ennek oka, hogy jellemzően az értékesített áruk mennyiségével nem nőnek egyenesen arányosan (sokkal inkább csökkenő arányban) a költségei, ami relatíve olcsóbbá teszi az áruk növekvő ütemủ értékesítését.

Az értékesítési adatok elemzésének legfontosabb módja azok időbeli alakulásának vizsgálata. Ezen keresztül pedig vizsgálható a piaci részesedés alakulása, az értékesítési színvonal (vevői elégedettség, piacösztönzés hatékonysága stb.) és a forgalom összetételének változása is. Az idősoros elemzések elvégzése során biztosítani kell vagy azt, hogy azonos természetes mértékegységben lehessen összevetni az azonos célt szolgáló termékeket, vagy pedig azt, hogy ha pénzértéken történik a számbavétel, akkor az időszak alatt bekövetkező árváltozások ne torzítsák el az értékesítési volumenben bekövetkező változásokat - azaz valamilyen bázisáron kell az értékelést elvégeznünk (bázisév vagy tárgyév). A kereskedelemben jellemzően jelen van a szezonalitás jelensége is, azaz, hogy bizonyos időszakokban (elsősorban éven belül, havonta, negyedévente stb.) az értékesítés rendszeresen magasabb, vagy alacsonyabb más időszakokhoz képest (pl. téli sporteszközök értékesítése ősszel és télen magasabb). Ennek kiküszöbölése fontos feladat, melynek keretében vagy mindig azonos időszak adatait hasonlítjuk össze egymással, vagy szezonindexszel korrigálni kell az adatokat. Végül fontos megemlíteni, hogy ha nem konkrét áruk vagy árucsoportok szintjén történik meg az értékesítési forgalom elemzése, hanem aggregáltan, akkor az elemzésbe bevont adatok köre ne változzon (pl. választék megváltozása vagy értékesítési profil megváltozása okán). 
Az értékesítési forgalom vizsgálata történhet az idősoros adatok felhasználásával trendszámítással, lánc- és bázisviszonyszámokkal, rugalmassági mutatókkal vagy az átlagos fejlődést leíró mutatószámokkal (fejlődés átlagos mértéke, fejlődés átlagos üteme). Emellett használatosak a megoszlási viszonyszámok, amelyek az egyes áruk, árucsoportok relatív súlyát mutatják be a teljes értékesítésen belül (lásd 2. fejezet).

\section{3. táblázat Az átlagos fejlödés leíró mutatók}

\begin{tabular}{|l|c|}
\hline $\begin{array}{l}\text { Mutató megne- } \\
\text { vezése }\end{array}$ & Mutató \\
\hline $\begin{array}{l}\text { Fejlődés átlagos } \\
\text { mértéke }\end{array}$ & $\sum$ Egyes években bekövetkezett forgalom változása \\
\hline $\begin{array}{l}\text { Fejlödés átlagos } \\
\text { üteme }\end{array}$ & $\begin{array}{r}\text { Vizsgált évek száma } \\
\text { Vizgált évek száma }\end{array}$ \\
\hline
\end{tabular}

A fejlődés átlagos mértéke azt mutatja meg, hogy átlagosan a vizsgált időszak során mennyivel változott a forgalom. Kiszámítása számtani átlag segítségével történik. Ugyanennek százalékos formában való kifejezésére való a fejlődés átlagos üteme, amely azt mutatja be, hogy az elemzett idősorra átlagosan hány százalékos fejlődés volt jellemző. Kiszámítására mértani átlagot használunk.

A piaci részesedést a vizsgált vállalkozás és a teljes piaci értékesítés részarányaként határozhatjuk meg, míg a relatív piaci részesedés a vizsgált vállalkozás értékesítésének a piacvezető vállalkozáshoz történő viszonyítását jelenti. Mindkét mutató a vállalkozás piacon betöltött szerepéhez és relatív súlyához szolgáltat információkat (11.4. táblázat).

\section{4. táblázat Piaci részesedési mutatók}

\begin{tabular}{|l|c|}
\hline \multicolumn{1}{|c|}{ Mutató megnevezése } & Mutató \\
\hline Piaci részesedés & $\frac{\text { Vállalkozás értékesítése }}{\text { Teljes piaci értékesítés }} \times 100$ \\
\hline Relatív piaci részesedés & $\frac{\text { Vállalkozás értékesítése }}{\text { Piacvezető vállalkozás értékesítése }} \times 100$ \\
\hline
\end{tabular}

Az értékesítés elemzése során külön figyelmet kell szentelni az árrés és az árréstömeg alakulására, hiszen ez a kereskedelmi tevékenység jutalma, a kereskedelmi vállalkozás hozzáadott értéke és szervezési, koordinációs tevékenységének mozgatórugója. Ahogy a 11.2. ábra is mutatja, az árrés az értékesítési árbevétel és az értékesített áru beszerzési értékének különbözete, amely egyúttal fedezetet nyújt a vállalkozás egyéb költségeire és magára az eredményre is (amelynek minél magasabb értéke a végső cél maga). Az árréstömeg két eltérő megközelítésből adódóan több módon is meghatározható. Egyrészt az árbevétel bizonyos százalékaként (ez az árrésszint), másrészt az eladott áruk beszerzési értékének bizonyos százalékaként (ez a haszonkulcs) (11.5. táblázat). Míg az árrésszint az egységnyi árbevételre eső árrést adja meg, 
addig a haszonkulcs azt a többletértéket, amellyel az ELÁBÉ megterhelésre kerül. Értelemszerüen mindkét mutató esetében kedvező, ha értékük minél magasabb. Az árréstömeg növekedése a vállalkozás alapvető érdeke. Megvalósulhat az árbevétel (forgalom) növelésével, a forgalom olyan irányú átrendeződésével, hogy a magasabb árréssel bíró áruk relatív súlya megnő az alacsonyabb árrésü termékekkel szemben, vagy az egy termékre jutó árrés növelésével (pl. a beszerzési egységköltség csökkentésével, vagy változatlan beszerzési költség mellett az ár növelésével).

11.5. táblázat Az árréstömeg segítségével kalkulálható mutatók

\begin{tabular}{|l|c|}
\hline \multicolumn{1}{|c|}{ Mutató megnevezése } & Mutató \\
\hline Árrésszint & $\frac{\text { Árréstömeg }}{\text { Árbevétel }} \times 100$ \\
\hline Haszonkulcs & $\frac{\text { Árréstömeg }}{\text { Eladott áruk beszerzési értéke }} \times 100$ \\
\hline
\end{tabular}

\subsection{A tárgyi eszköz-gazdálkodás sajátosságai a kereskedelemben}

A kereskedelemben használatos tárgyi eszközöknek két csoportját különböztetjük meg. Azokat a technikai eszközöket, amelyek az árumozgatásban és az értékesítésben, ill. az ügyviteli folyamatokban vesznek részt, valamint a létesítményeket, amelyek az áruforgalom lebonyolításának színterei. A kereskedelemben használatos tárgyi eszközök összetételének, használhatóságának elemzése megegyezik bármely más ágazat tárgyi eszközeinek elemzésével.

A kereskedelemben használatos technikai eszközök kapacitáskihasználása a 9.2.1-es fejezetben már bemutatott általános kapacitáskihasználási mutatón kívül jellemezhető még a 7.4.2-es fejezetben leírt eszközhatékonysági mutatókkal. Itt csak megemlítés szintjén térünk ki rá ismét, hogy a kereskedelmi vállalkozás technikai eszközökkel való ellátottságát a rendelkezésre álló alapterület és a vállalkozásban foglalkoztatottak létszáma alapján szokás megítélni. Mindkét esetben annál kedvezőbb a vállalkozás helyzete, minél nagyobb a mutatók értéke, de általánosan meghatározható optimális szintje nincsen, inkább a vállalkozás korábbi értékeihez vagy az iparágban tevékenykedő más versenytársakhoz érdemes hasonlítani. A technikai eszközállomány számbavételéhez használható annak bruttó, nettó vagy piaci értéke is.

Mivel létesítmények (pl. raktár, üzlethelyiség) nélkül a kereskedelmi vállalkozások nem láthatják el feladataikat - még az online webáruházaknak is szükségük van legalább minimális mértékben raktárhelyiségre - ezért azok kihasználtsága is elemzendő lehet. Sőt amennyiben egynél több ilyen létesítménnyel rendelkezik a vállalkozás, akkor már kereskedelmi hálózatról is beszélhetünk (ami nem feltétlenül jelent két boltot, hanem lehet az egy bolt és egy raktár is), amelynek értékeléséhez ismernünk kell annak kapacitás-mutatóit. A hálózat áteresztőképességének nevezzük azt a forgalmat, amelyet adott időszak alatt maximálisan lebonyolítani képes lehet. Szükséges kapacitásnak tekintjük a vevők által támasztott kereslet kiszolgálásához szükséges területi igényt, amelytől azonban a rendelkezésre álló kapacitás eltérhet. A kettő 
hányadosa a létesítmények kapacitás-kihasználtsági mutatója. Ha a szükséges kapacitás nagyobb, mint a rendelkezésre álló, akkor hiányról beszélünk, ellenkező esetben kapacitásfelesleg van. Előbbi esetben szükséges lehet a kapacitások bővítése - ha az gazdaságosan megvalósítható -, utóbbi esetben pedig törekedni kell a kereslet növelésére, hogy a felesleges kapacitások még hatékonyabban hasznosuljanak.

$$
\text { Létesítmények kapacitás }- \text { kihasználtsága }=\frac{\text { Rendelkezésre álló kapacitás }\left(\mathrm{m}^{2}\right)}{\text { Szükséges kapacitás }\left(\mathrm{m}^{2}\right)}
$$

Ehhez kapcsolódóan érdemes megemlíteni az egy boltra jutó forgalom nagyságát jelző mutatót is, amelynek minél magasabb értéke kívánatos. Ez jó viszonyítási alapot szolgáltathat a hálózat egyes boltjai számára, feltéve, ha azok nagyságrendileg azonos paraméterekkel (foglalkoztatotti létszám, alapterület stb.) rendelkeznek.

$$
\text { Egy boltra jutó forgalom }=\frac{\text { Értékesítési forgalom }}{\text { Boltok száma }}
$$

A boltokban foglalkoztatott munkavállalók leterheltsége - tekintve, hogy a kereskedelmi tevékenység különösen élőmunka-igényes - is fontos eleme a hatékony munkavégzésnek. Erröl ad részben tájékoztatást az, hogy egy-egy munkavállalónak átlagosan mekkora alapterületet kell úgymond kiszolgálnia, vagy ellátnia (más típusú leterheltségi mutatókat lásd a 7.4.1-es fejezetben).

$$
\text { Ellátandó terület }=\frac{\text { Bolti alapterület }\left(\mathrm{m}^{2}\right)}{\text { Átlagos foglalkoztatotti létszám }}
$$

\subsection{A vendéglátás elemzési sajátosságai}

E fejezetben a vendéglátáson belül is a szálláshely-szolgáltatásra koncentrálunk, mivel az éttermi vendéglátás áruforgalmi elemzése nagyrészt megegyezik bármely kereskedelmi vállalkozás áruforgalmi elemzésével - természetesen néhány sajátosság azért adódik - de alapvetően nagy különbségek nincsenek és a korábban leírt módszerek jól alkalmazhatók ezen a területen is.

Szálláshely-szolgáltatás a TEÁOR definíciója szerint: az egy- vagy többágyas szobákban átmeneti tartózkodás céljából nyújtott szálláshelyi szolgáltatás látogatók és utazók számára. Szintén ide tartozik a hosszabb időtartamra kimondottan diákok, munkások és hasonló személyek számára nyújtott szálláshelyi szolgáltatás. A lakóhelyi célú szállásbiztosítást (albérlet) nem ide soroljuk. (KSH, 2019)

Ezen a területen az értékesítési mennyiség mértékegysége a szobaéjszaka vagy vendégéjszaka. Ennek megfelelően sajátos mutatók számítására kerülhet sor.

A termelökapacitásnak megfelelően ebben az iparágban a szobák/ágyak kapacitásának kihasználtságát kell vizsgálni (11.6. táblázat). Ezt meg lehet tenni szobára, vagy még ennél is 
részletesebben, ágyra vetítetten. Ezek a kapacitásmutatók jelentős szezonális ingadozást mutathatnak éven, hónapon vagy akár héten belül is (pl. nyári vagy téli nyaralások, hosszú hétvégék miatt), de alapvető cél, hogy a mutató értéke minél magasabb legyen (éves időhorizonton a 60\%-os kihasználtság már jónak mondható, frekventált időszakokban azonban a 80-90\%-os arány elvárható). A kapacitás-kihasználtsági mutatókban használt maximális kapacitások kiszámítása a kiadható szobák/ágyak száma és a vizsgálati időszak napjainak szorzata. A kiadott szoba vagy ágyszám számításakor pedig minden egyes napot figyelembe kell venni, amikor egy szoba vagy ágy vendégek számára kiadásra került (tehát nem azt mérjük, hogy hányszor cserélődtek a vendégek és hány különböző vendégnek kerültek kiadásra).

A megtermelhető bevételek és a ténylegesen elért bevételek arányát a bevételkapacitás-mutató számszerüsíti, mely az előző két mutatóval együtt mozog értelemszerűen.

Az átlagos tartózkodási idő mutatója logikájában eltér a másik három kapacitás-mutatótól, arra keresi a választ, hogy egy-egy vendég átlagosan hány napon keresztül foglalt egy ágyat, azaz mennyi ideig tartózkodott a szállodában. Alapvetően az a jó, ha ez minél hosszabb, hiszen a sürün cserélődő vendégek többletköltségeket generálnak a szálloda müködésében.

\section{6. táblázat Kapacitás-kihasználtsági mutatók a szálláshelyi szolgáltatásban}

\begin{tabular}{|c|c|}
\hline Mutató megnevezése & Mutató \\
\hline \multirow{2}{*}{$\begin{array}{l}\text { Szobakapacitás-kihasznált- } \\
\text { ság }\end{array}$} & Kiadott szobaszám \\
\hline & $\overline{\text { Maximálisan kiadható szobaszám }}{ }^{\prime}$ \\
\hline \multirow{3}{*}{ Ágykapacitás-kihasználtság } & Kiadott ágyak száma (pótágy nélkül) \\
\hline & Maximálisan kiadható ágyak száma (pótágy nélkül) \\
\hline & $\times 100$ \\
\hline \multirow{2}{*}{$\begin{array}{l}\text { Bevétel-kapacitás kihasz- } \\
\text { náltsága }\end{array}$} & Nettó bevétel \\
\hline & $\overline{\text { Maximálisan elérhető nettó bevétel }}$ \\
\hline \multirow{2}{*}{$\begin{array}{l}\text { Átlagos tartózkodási idő } \\
\text { (nap) }\end{array}$} & Kiadott ágyak száma \\
\hline & Vendégek száma \\
\hline
\end{tabular}

A hatékonysági mutatók a kapacitás-kihasználtsági mutatókhoz hasonlóan hasonlítanak a termelö/kereskedelmi vállalkozások azonos mutatóihoz, azonban itt a vetítési alapot értelemszerüen a vendégek/vendégéjszakák/szobák jelentik.

Míg a vendégéjszakák és vendégek számára vetített árbevétel az egy-egy vendég vagy eltöltött éjszaka kiszolgálásához kapcsolódó bevételeket jelenti, addig a maximálisan kiadható szobákra vetített árbevétel (egy szobára jutó árbevétel - amely alatt a szobaszám és az időszak értékesítési napjainak szorzatát értjük) nincsen ilyen szoros összefüggésben a vendégkiszolgálás eredményességével. Ezt a mutatót egyfajta beruházás-gazdaságossági értékelö-számnak is tekinthetjük, mivel az infrastruktúra müködtetésének bevételtermelö képességét jelenti (11.7. táblázat). 


\begin{tabular}{|c|c|}
\hline Mutató megnevezése & Mutató \\
\hline \multirow{2}{*}{$\begin{array}{l}\text { Egy vendégéjszakára jutó ár- } \\
\text { bevétel }\end{array}$} & Nettó szállodai bevétel \\
\hline & Vendégéjszakák száma összesen \\
\hline \multirow{2}{*}{ Egy vendégre jutó bevétel } & Nettó szállodai bevétel \\
\hline & $\overline{\text { Vendégek száma összesen }}$ \\
\hline \multirow{2}{*}{$\begin{array}{l}\text { Egy kiadható szobára eső ár- } \\
\text { bevétel (Revenue per Avai- } \\
\text { lable Room, REVPAR) }\end{array}$} & Nettó szállodai árbevétel \\
\hline & Kiadható összes szobák száma \\
\hline
\end{tabular}

A vállalkozás versenytársakhoz mérése több szempontból is elvégezhető. A kapacitás-részesedés mutatója százalékosan fejezi ki, hogy a vállalkozás a teljes piaci kapacitás mekkora részével rendelkezik. Minél nagyobb az értéke, annál meghatározóbb szereplö lehet a piacon a vállalkozás. Az értékesített szobakapacitási mutató az összes piaci szereplő által kiadott szobák számán belül vizsgálja a vállalkozás részesedését (tulajdonképpen ez a piacrészesedési mutató). Természetesen a cél az, hogy minél magasabb részesedést mondhasson magáénak egy vállalkozás, melynek esélye annál nagyobb, minél magasabb a kapacitás-részesedési mutatója.

Tulajdonképpen ennek az összefüggésnek a leírására való a kihasználtsági mutató az előző két mutató hányadosa, ami mindkét részesedési mutatót figyelembe veszi. Értéke meghaladhatja az 1-et is, amennyiben az értékesítési mutatója jobb a vállalkozásnak annál, mint amenynyit a rendelkezésére álló kapacitások indokolnának. Amennyiben 1-nél kisebb, akkor a teljesítménye rosszabb az elvárhatóhoz képest. A vállalkozás által elért átlagárat a piacon érvényes átlagárhoz viszonyítja az átlagár-részesedési mutató. Ha értéke meghaladja a 100\%-ot, akkor a vállalkozás árai magasabbak a piaci árhoz képest, amely azonban önmagában még se nem jó, se nem rossz, az igazi kérdés az, hogy ehhez mekkora vendégéjszaka-szám tartozik. A bevételképzési mutató a vállalkozás bevételképző képességét és a piac teljes egészének bevételképző képességét veti össze. Akkor lehet versenyelőnyben a vállalkozás, ha értéke nagyobb, mint egy (11.8. táblázat). 
11.8. táblázat Piacrészesedési mutatók a szálláshely-szolgáltatásban

\begin{tabular}{|c|c|}
\hline Mutató megnevezése & Mutató \\
\hline \multirow{2}{*}{$\begin{array}{l}\text { Kapacitás-részesedési } \\
\text { mutató (Fair Share) }\end{array}$} & Kiadható szobák száma \\
\hline & Piacon meglévő összes kiadható szobaszám $\times 100$ \\
\hline \multirow{2}{*}{$\begin{array}{l}\text { Értékesített szobakapaci- } \\
\text { tási részesedés (Market } \\
\text { Share) }\end{array}$} & Kiadott szobák száma \\
\hline & $\overline{\text { Piacon kiadott összes szoba száma }}$ \\
\hline \multirow{2}{*}{$\begin{array}{l}\text { Kihasználtsági mutató } \\
\text { (Market Penetration In- } \\
\text { dex, MPI) }\end{array}$} & Értékesített szobakapacitási részesedés \\
\hline & Kapacitás - részesedési mutató \\
\hline \multirow{2}{*}{$\begin{array}{l}\text { Átlagár-részesedési mu- } \\
\text { tató (Average Rate In- } \\
\text { dex, ARI) }\end{array}$} & Egy szobára jutó átlagár \\
\hline & $\overline{\text { Egy szobára jutó piaci átlagár }} \times 100$ \\
\hline \multirow{2}{*}{$\begin{array}{l}\text { Bevételképzési mutató } \\
\text { (Revenue Generation In- } \\
\text { dex, RGI) }\end{array}$} & Egy kiadható szobára eső árbevétel \\
\hline & zállodák egy kiadható szobájára eső á \\
\hline
\end{tabular}

\section{Forrásjegyzék}

1) Bán, E., Kresalek, P., Pucsek, J. (2017.). A vállalati gazdálkodás elemzése. Budapest: Perfekt Gazdasági Tanácsadó, Oktató és Kiadó Zrt.

2) Birher, I., Pucsek, J., Sándor, L., Sztanó, I. (2009). A vállalkozások tevékenységének gazdasági elemzése. Budapest: Perfekt Gazdasági Tanácsadó, Oktató és Kiadó Zrt.

3) Bíró, T., Kresalek, P., Pucsek, J., Sztanó, I. (2016). A vállalkozások tevékenységének komplex elemzése. Budapest: Perfekt Gazdasági Tanácsadó, Oktató és Kiadó Zrt.

4) Központi Statisztikai Hivatal. (2019). KSH - Osztályozások - Gazdasági tevékenységek egységes ágazati osztályozási rendszere (TEÁOR'08). Letöltés dátuma: 2019.. 08. 10., forrás: https://www.ksh.hu/teaor_kereso 